Selected Annotated Bibliography on Asphalt-Bearing Rocks of the United States and Canada, to 1970

G EOLOG I C A L SURVEY B LLETIN 1352 



\section{Selected Annotated Bibliography}

on Asphalt-Bearing Rocks of the United States and Canada,

\section{to 1970}

3y MARJORIE C. MULLENS and ALBERT E. ROBERTS

G E O L O G I C A L S U R V E Y B U L L E T I N 1352

A compilation of about 600 selected

eferences pertaining to the geology

and occurrence of asphalt-bearing rocks 


\section{UNITED STATES DEPARTMENT OF THE INTERIOR}

ROGERS C. B. MORTON, Secretary

\section{GEOLOGIGAL SURVEY}

V. E. McKelvey, Director

Library of Congress catalog-card No. 72-600019

For sale by the Superintendent of Documents, U.S. Government Printing Office Washington, D.C. 20402 - Price $\$ 1.25$ (paper cover)

Stock Number 2401-2110 


\section{CONTENTS}

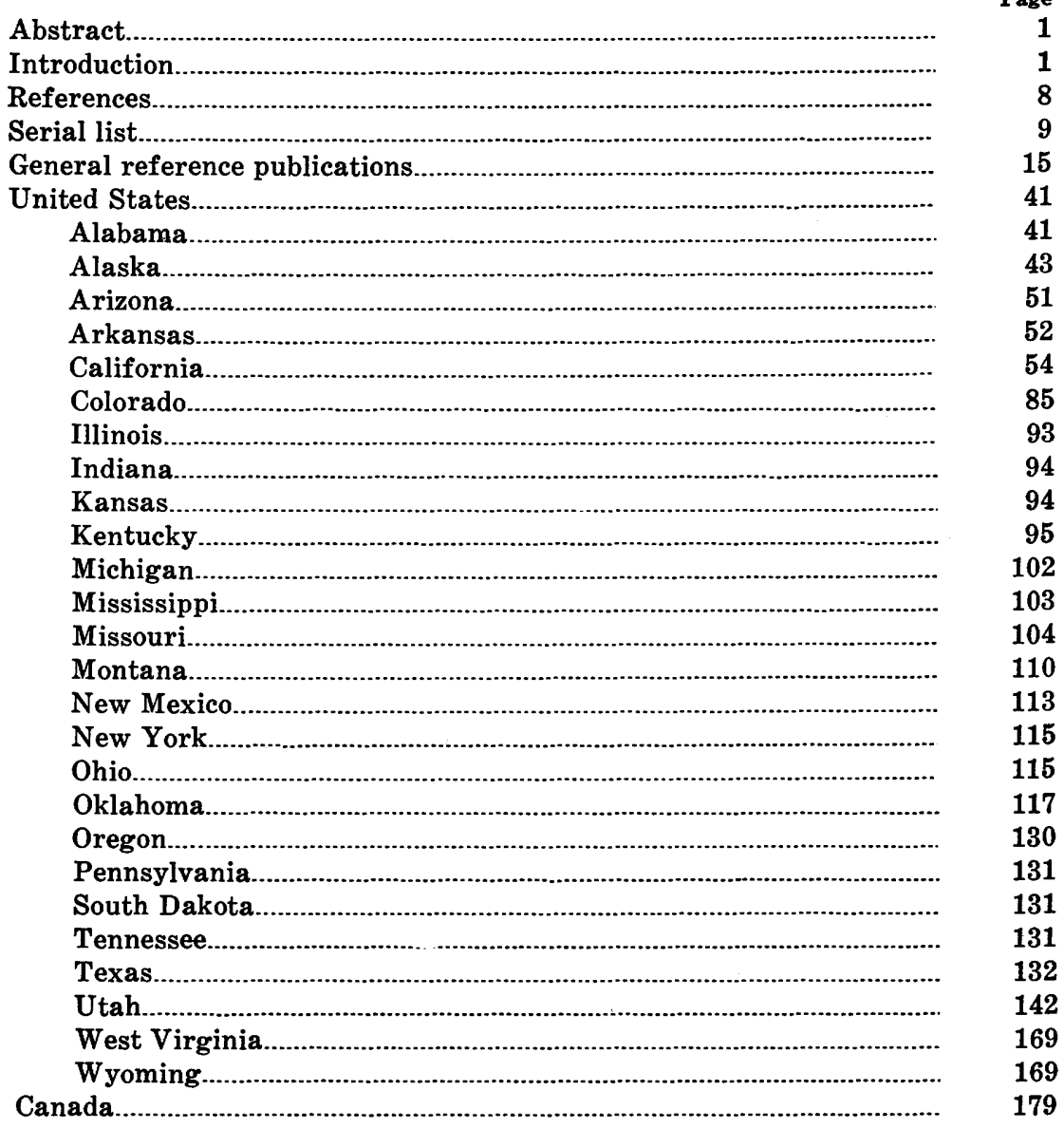

\section{ILLUSTRATIONS}

FIGURE 1. Photograph of asphaltic sandstone.

2. Photograph showing top of bituminous sand uncovered by erosion.

3. Photograph of gilsonite vein. 
Figure 4. Photograph of La Brea tar pit, Los Angeles

County, Calif.

5. Map showing distribution of asphalt-bearing rocks in the United States.

\section{TABLE}

TABLE 1. Asphalt deposits in the United States with reserves

Page of at least 1 million barrels. 


\title{
SELECTED ANNOTATED BIBLIOGRAPHY ON ASPHALT-BEARING ROCKS OF THE UNITED STATES \\ AND CANADA, TO 1970
}

\author{
By Marjorie C. Mullens and Albert E. Roberts
}

\section{ABSTRACT}

Surface and near-surface deposits of asphalt-bearing rocks in the United States and Canada are a potential source of energy. Economic conditions and technological advances indicate that these deposits may supplement future petroleum production. Energy planning and research for future needs should include a balanced program of the various energy resources. Because implementation of such a program requires an assemblage of pertinent data on asphalt-bearing rocks, this annotated bibliography was prepared.

\section{INTRODUCTION}

Asphalt-bearing rocks have been recognized for many years as a potential source of synthetic-crude oil. The expanding search for new supplies of energy during recent years and an advancing technology for the recovery of petroleum products from these rocks have revived interest in their possible development. Large-scale production from the giant Canadian Athabaska deposit began in 1967. At present, a few of the larger United States deposits are being worked on an experimental basis; however, as recovery methods improve and economic conditions become more favorable, many of these deposits are expected to become commercial.

Bituminous substances range in form from liquid petroleum through semisolid varieties that are partly insoluble in organic solvents but are higher in fixed carbon and less fusible, to solid asphaltic pyrobitumens that are nearly insoluble and infusible and are high in fixed carbon. The widely differing characteristics of asphalt-bearing rocks make it difficult to describe them with one all-inclusive definition. Such terms as albertite, asphalt, asphaltite, asphaltum, bitumen, brea, chapapote, gilsonite, grahamite, maltha, mineral wax, oil seepages, pitch, resin, and tar sands have been used somewhat indiscriminately in the literature in descriptions of widely divergent types of deposits. For a comprehensive review of terminology and classification of 
bituminous substances, the reader is referred to Herbert Abraham's (1960, chap. 2, v. 1, 6th ed.) "Asphalts and Allied Substances," or to "Nomenclature and terms," by W. E. Hansen, in "Bituminous Materials - Asphalts, Tars, and Pitches," volume 1, edited by A. J. Hoiberg (1964).

The term "asphalt-bearing rock" is used in this bibliography for any deposit that is impregnated with the very heavy and highly viscous hydrocarbon, commonly known as "asphalt," or "tar." The hydrocarbon can generally be extracted from the entrapping rock by organic solvents, hot- or cold-water washing, low-temperature retorting, or centrifuge treatment. Extracted hydrocarbon can be processed to yield oil, natural gas, gasoline, liquefied-petroleum gas, and solids as accessory products. In practice, the distinction between asphalt sands and sands containing heavy-crude oil is not easily made. The principal difference between asphalt-bearing rocks and oil shale is that the hydrocarbon in the more porous asphalt-bearing rocks can be removed by ordinary organic solvents, whereas the hydrocarbon in oil shale cannot.

Asphalt-bearing deposits most commonly occur around the margins of oil-producing basins in which the oil-containing formations are near the surface. The locations of many of the early discovery oil wells were on or near outcrops of asphalt-bearing rocks. Asphalt deposits also occur within the basins where folds and faults have brought these asphalt-bearing formations to the surface. Prior to production of petroleum from wells, such deposits were mined for recovery of petroleum products and for road material. A few asphalt-bearing rocks are being mined at the present time for the asphalt; however, 90 percent of the asphalt used in the United States is produced from the refining of crude petroleum.

The deposits of asphalt-bearing rock have become immobile in relatively porous rocks by processes that are not as yet clearly understood. The presence of asphalt in widely divergent lithologic rock types of both marine and nonmarine origin suggests that, at many localities, the parent hydrocarbons have migrated from source rocks into the porous reservoirs, from which the lighter, more volatile constituents subsequently escaped, leaving behind the highly viscous and relatively inert residue of petroleum. The permeability of the clastic rocks may be a dominant factor in the localization of the asphalt, although other factors, such as texture, cementation, jointing, faulting, folding, tilting, and the position of the water table, all may exert some control in the accumulation of asphalt. In some deposits hydrocarbon is undoubtedly the residuum from evaporation of the light volatile end-fraction, 
but in other deposits the hydrocarbons contain high percentages of light-end low-boiling fractions. The parent crude oil in some deposits may be immature and, therefore, unlikely to have undergone compression from excessive overburden pressure; or in other deposits it may be old, having lost its light volatile ends after originating at considerable depth and migrating to its present position. Source material and source environment may have influenced the type of original crude formed; and the destructive role of bacteria may have influenced the chemical constituents formed. Also, in a few deposits, possibly little or no migration has occurred, and the hydrocarbons are indigenous to the present reservoir rocks. For a modern review of hypotheses for organic and inorganic origins of petroleum, the reader is referred to "Sourcebook for Petroleum Geology," compiled by R. H. Dott, Sr., and M. J. Reynolds (1969).

Many asphalt deposits are obviously due to seepage of petroleum at or near the surface into a porous rock (fig. 1), whereas other deposits appear to be in-situ oil accumulations uncovered by erosion (fig. 2). In some deposits there are veinlike fillings of solid hydrocarbons, such as gilsonite, which are often associated with faulting and folding and occasionally occur as asphaltbearing sandstone dikes and sills (fig. 3). Some deposits are

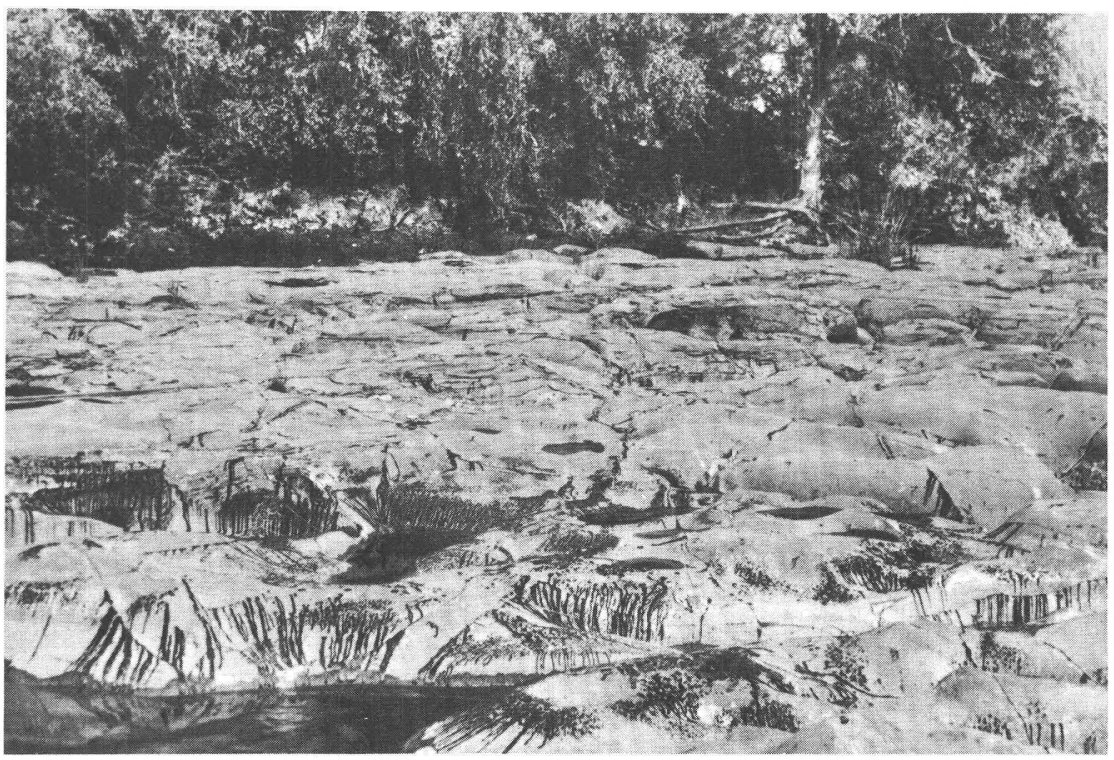

Figure 1. - Asphaltic sandstone, viewed at close range. Streaks are asphalt that has oozed from the rock and trickled down the sloping surfaces. Outcrop is in Zavalla County, Tex. Photograph by L. W. Stephenson. 


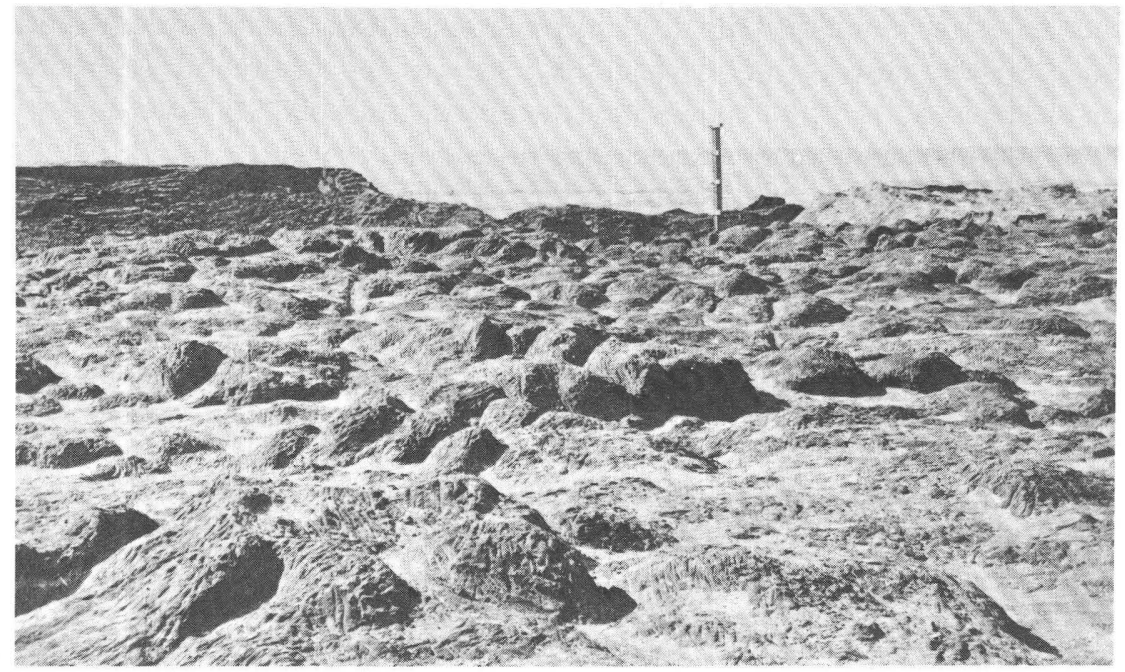

Figure 2. - Top of bituminous sand at Carpinteria, Calif., exposed by erosion. Photograph taken by George H. Eldridge in 1901.

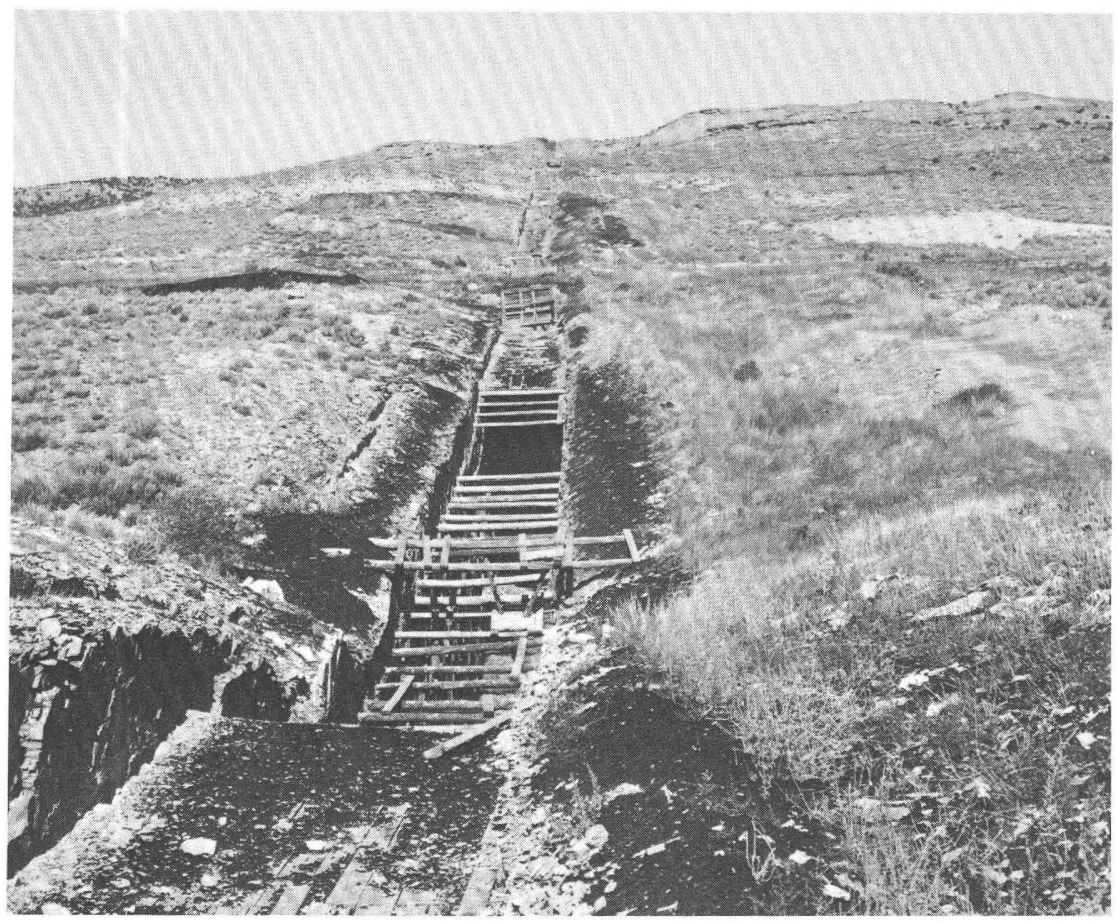

FIgURE 3. - Cowboy gilsonite vein, viewed toward the northwest along vein in sec. 22, T. 9 S., R. 25 E., Uintah County, Utah. Platform (foreground) is approximately 10 feet wide. Photograph taken by W. B. Cashion in 1967. 


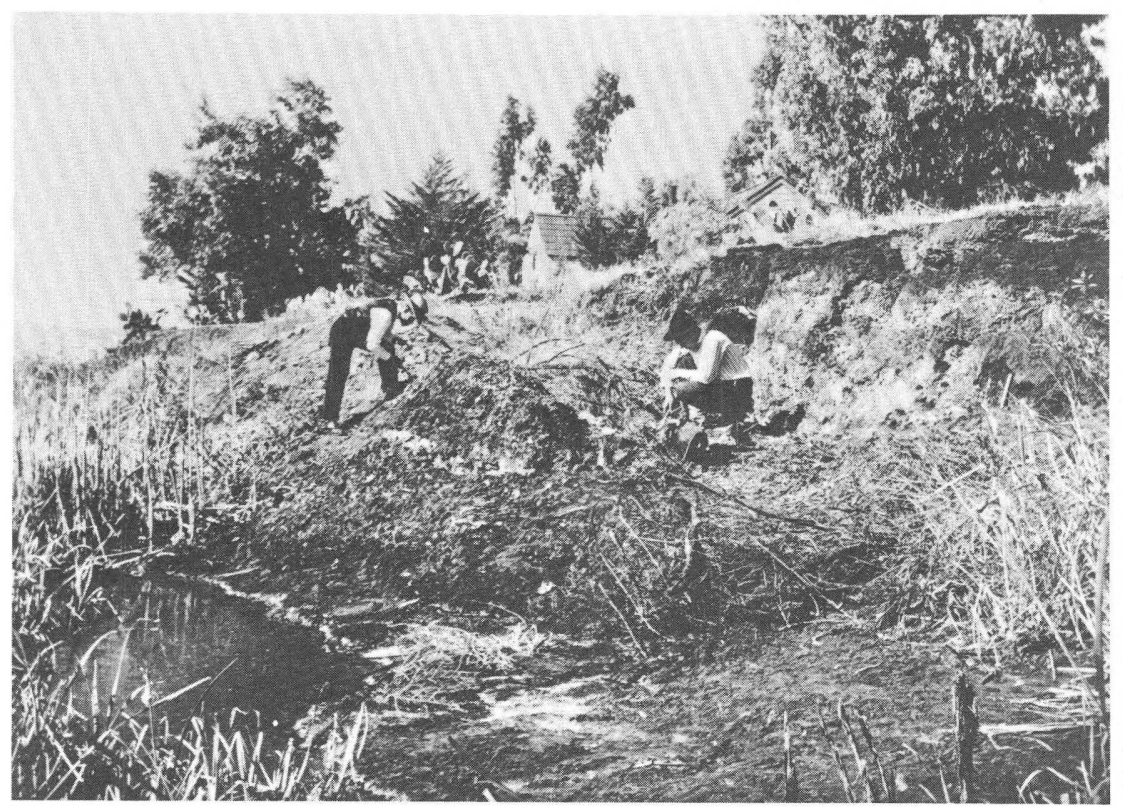

Figure 4. - North side of lagoon at La Brea tar pit, Los Angeles County, Calif. Photograph made by Ralph Arnold in 1906.

evidently the result of flowage of plastic hydrocarbons into localities of less pressure (fig. 4). Deposits vary from semiliquid to hard brittle material. Available evidence indicates that the now solid or plastic asphaltlike substances had the same origin as crude oil and were, in fact, liquid petroleum when emplaced.

The index map (fig. 5) shows the distribution of asphaltbearing rocks in the United States (excluding Hawaii), and table 1 details the deposits in which the reserves total at least 1 million barrels of oil.

This selected bibliography, compiled in support of the U.S. Geological Survey organic-fuels investigations, is an attempt to condense the broad published record into brief annotated refer- 


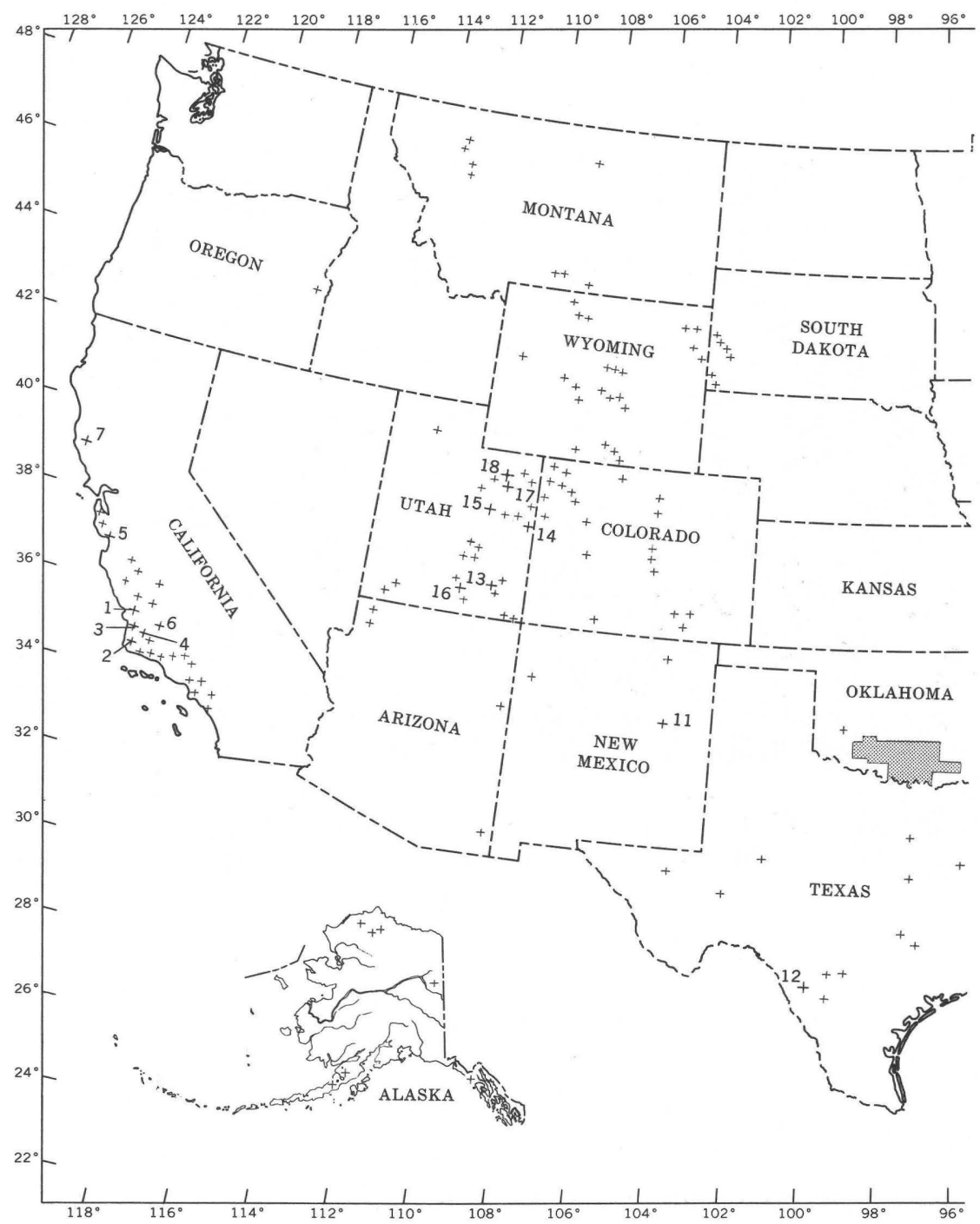

FIGURE 5. - Distribution of asphalt-bearing rocks in the United States. After ences listed by State, that will be helpful to future researchers of asphalt-bearing rocks. The selected publications include most of the geologic and geochemical literature on asphalt-bearing rocks of the United States and Canada prior to 1970. Detailed geologic information concerning asphalt-bearing rocks is sparse and fragmented, although general descriptions are numerous. Most of the general descriptions are in reports concerned primarily with other subjects, and the treatment of asphalt-bearing 


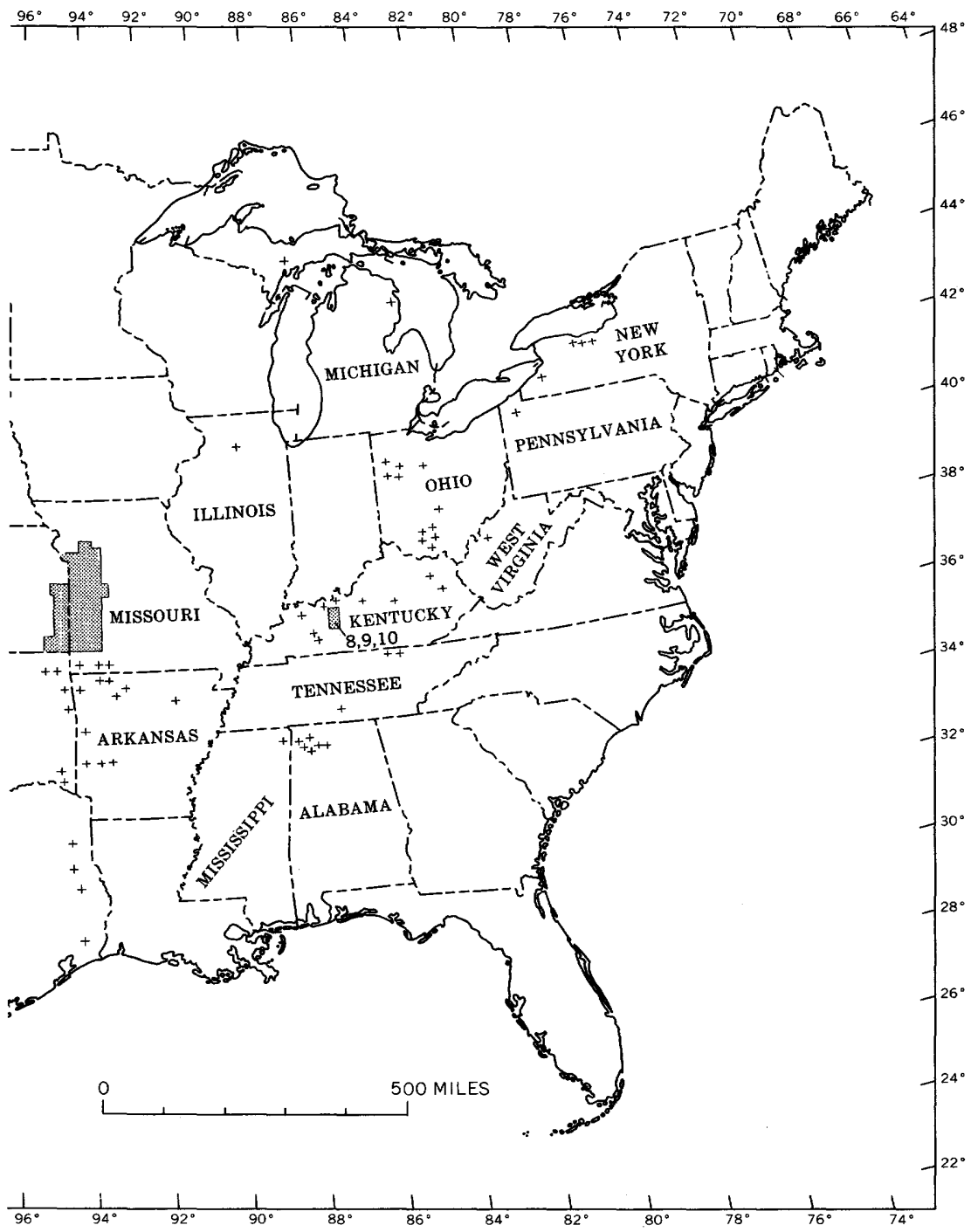

Ball Associates, Ltd. (1965). Numbers refer to deposits listed in table 1.

rocks is incidental. For reports concerned primarily with other subjects, only material pertaining to asphalt is described, and brackets are used to indicate the pages pertinent to asphaltbearing rocks in the bibliographic reference.

Where possible, the author's abstract or text was used in condensed form and a notation to this effect follows the reference. If no notation follows, the abstracting was written by Marjorie Mullens. 
TABLE 1. - Asphalt deposits in the United States with reserves of at least 1 million barrels

[Source of data: Utah, Ritzma (1969) ; other States, Ball Associates, Ltd. (1965)]

\begin{tabular}{|c|c|c|}
\hline $\begin{array}{l}\text { Deposit No- } \\
\text { (fig. } 5 \text { map) }\end{array}$ & Name of deposit & $\begin{array}{c}\text { Reserves } \\
\text { (millions of barrels) }\end{array}$ \\
\hline \multicolumn{3}{|c|}{ California } \\
\hline 1. & Edna... & \multirow{7}{*}{$\begin{array}{rr}141.4- & 166.4 \\
& 46.4 \\
& 40.0 \\
26.0- & 50.0 \\
& 10.0 \\
4.8- & 9.0 \\
& 1.2\end{array}$} \\
\hline 2. & South Casmalia. & \\
\hline 3 & North Casmalia.. & \\
\hline & Sisquoc & \\
\hline ................. & Santa Cruz... & \\
\hline $6 \ldots$ & McKittrick.. & \\
\hline (n)................... & Point Arena. & \\
\hline \multicolumn{3}{|c|}{ Kentucky } \\
\hline & Kyrock area. & \multirow{3}{*}{$\begin{array}{rr} & 18.4 \\
7.5-\quad 11.3 \\
& 7.6\end{array}$} \\
\hline 9 & Davis-Dismal area. & \\
\hline $10 .$. & Bee Spring area....... & \\
\hline \multicolumn{3}{|c|}{ New Mexico } \\
\hline 11. & Santa Rosa.. & 57.2 \\
\hline \multicolumn{3}{|c|}{ Texas } \\
\hline 12. & 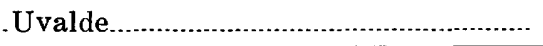 & $124.1-140.7$ \\
\hline \multicolumn{3}{|c|}{ Utah } \\
\hline & Tar Sand Triangle.. & \multirow{6}{*}{$\begin{array}{rr}3,500 & -5,000 \\
& 3,700 \\
2,000 & -3,000 \\
1,000 & -1,300 \\
1,000 & -1,200 \\
65.0-125.0\end{array}$} \\
\hline & P. R. Springs. & \\
\hline $15 \ldots$ & Sunnyside.... & \\
\hline & Circle Cliffs.. & \\
\hline & Asphalt Ridge.. & \\
\hline & Whiterocks... & \\
\hline
\end{tabular}

More than one reference is made to the same report if the report contains detailed descriptions of two or more important asphalt deposits. Each annotated list of publications that contains more than two or three references is preceded by a separate subject index.

The nomenclature used.in this report is from many sources and may not conform with that in use by the U.S. Geological Survey.

\section{REFERENCES}

Abraham, Herbert, 1960, Asphalts and allied substances - their occurrence, modes of production, uses in the arts, and methods of testing, v. 1 of Historical review and natural raw materials [6th ed.]: Princeton, N.J., D. Van Nostrand Co., $370 \mathrm{p}$.

Ball Associates, Ltd., compiler, 1965, Surface and shallow oil-impregnated rocks and shallow oil fields in the United States: U.S. Bur. Mines Mon. $12,375 \mathrm{p}$.

Dott, R. H., Sr., and Reynolds, M. J., compilers, 1969, Sourcebook of petroleum geology: Am. Assoc. Petroleum Geologists Mem. 5, 471 p. 
Hoiberg, A. J.; ed., 1964, General aspects, v. 1 of Bituminous materials Asphalts, tars, and pitches: New York, Interscience Publishers, $432 \mathrm{p}$.

Ritzma, H. R., 1969, Oil-impregnated sandstone deposits of Utah - A progress report: Interstate Oil Compact Comm. Committee Bull., v. 11, no. 2, p. 24-38.

\section{SERIAL LIST}

Publications cited here in abstract form are available in most geological libraries, and most theses are available on microfilm from University Microfilms, Inc., Ann Arbor, Mich. 48104. A list of the journals commonly cited in this and other Geological Survey publications may be obtained by writing to the U.S. Geological Survey, Washington, D.C. 20242.

Alabama Geol. Survey Circ. - Geological Survey of Alabama Circular. University, Ala.

Alabama Geol. Survey Special Rept. - Geological Survey of Alabama Special Report. University, Ala.

Am. Assoc. Petroleum Geologists Bull. - Bulletin of the American Association of Petroleum Geologists. Tulsa, Okla.

Am. Assoc. Petroleum Geologists Mem. - Memoir of the American Association of Petroleum Geologists. Tulsa, Okla.

Am. Chem. Soc. Jour. - Journal of American Chemical Society. Washington, D.C.

Am. Inst. Mining Eng. Trans. See Am. Inst. Mining, Metall., Petroleum Engineers Trans.

Am. Inst. Mining and Metall. Engineers Contr. - Contributions of American Institute Mining and Metallurgical Engineers, New York, N.Y.

Am. Inst. Mining, Metall., Petroleum Engineers Trans. - Transactions of the American Institute of Mining, Metallurgical, and Petroleum Engineers. New York, N.Y.

Am. Soc. Testing and Materials Proc. - American Society for Testing and Materials Proceedings. Philadelphia, Pa.

Anal. Chemistry - Analytical Chemistry. American Chemical Society. Washington, D.C.

Arizona Bur. Mines Bull. - Arizona Bureau of Mines Bulletin. Tucson, Ariz. Arizona State Land Dept. Rept. - Arizona State Land Department Report. Phoenix, Ariz.

Arizona Univ. Bull. - University of Arizona Bulletin. Tucson, Ariz.

Arkansas Geol. Comm. Bull. - Arkansas Geological Commission Bulletin. Little Rock, Ark.

Arkansas Geol. Survey, Bull. See Arkansas Geol. Comm. Bull.

Arkansas Geol. Survey, County Mineral Rept. See Arkansas Geol. Comm. Bull.

Bull. Canadian Petroleum Geology - Bulletin of Canadian Petroleum Geology. Published by Alberta Society of Petroleum Geologists, Edmonton Geological Society, and Saskatchewan Geological Society. Alberta Society of Petroleum Geologists. Calgary, Alberta, Canada.

California Div. Mines and Geology Bull. - California Division of Mines and Geology Bulletin. San Francisco, Calif.

California Div. Mines and Geology County Rept. - California Division of Mines and Geology County Report. San Francisco, Calif. 
California Div. Mines and Geology Mineral Inf. Service - California Division of Mines and Geology Mineral Information Service. San Francisco, Calif.

California Jour. Mines and Geology - California Journal of Mines and Geology (after Oct. 1958 incorporated in California State Mineralogist Rept.). San Francisco, Calif.

California Oil Fields - Summary Operations - California oil fields - Summary of operations. State of California Resources Agency, Department of Conservation, Division of Oil and Gas. Sacramento, Calif.

California State Mineralogist Rept. - California State Mineralogist Report. San Francisco, Calif.

California State Mining Bur. Bull. See Calif. Div. Mines and Geology Bull.

Canada Dept. Energy, Mines and Resources Mines. Br. Inf. Circ. - Canada Department of Energy, Mines and Resources, Mines Branch Information Circular. Ottawa, Ontario, Canada.

Canada Dept. Energy, Mines and Resources Mines Br. Rept. Inv. - Canada Department of Energy, Mines and Resources, Mines Branch Report of Investigations. Ottawa, Ontario, Canada.

Canada Dept. Energy, Mines and Resources Mines Br. Research Rept. Canada Department of Energy, Mines and Resources, Mines Branch, Research Report. Ottawa, Ontario, Canada.

Canada Dept. Mines, Mines Br. Rept. Inv. See Canada Dept. Energy Mines and Resources Mines Br., Rept. Inv.

Canada Geol. Survey Ann. Rept. See Canada Geol. Survey Summary Rept.

Canada Geol. Survey Econ. Geology Rept. - Geological Survey of Canada Economic Geology Report. Ottawa, Ontario, Canada.

Canada Geol. Survey Rept. of Progress. See Canada Geol. Survey Summary Rept.

Canada Geol. Survey Rept. - Geological Survey of Canada Summary Report. Ottawa, Ontario, Canada.

Canadian Inst. Mining and Metallurgy Trans. - Transactions of the Canadian Institute of Mining and Metallurgy and of the Mining Society of Nova Scotia. Montreal, Quebec, Canada.

Canadian Mining and Metall. Bull. - The Canadian Mining and Metallurgical Bulletin. The Canadian Institute of Mining and Metallurgy. Montreal, Quebec, Canada.

Canadian Oil and Gas Indus. - Canadian Oil and Gas Industries. National Business Publications, Ltd. Gardenvale, Quebec, Canada.

Carnegie Inst. Washington Pub. - Carnegie Institution of Washington Publication. Washington, D.C.

Colorado Geol. Survey Bull. - Colorado Geological Survey Bulletin. Boulder, Colorado.

Colorado School Mines Quart. — Quarterly of the Colorado School of Mines. Golden, Colo.

Econ. Geology - Economic Geology and the Bulletin of the Society of Economic Geologists. The Economic Geology Publishing Company. Blacksburg, Va.

Eng. and Mining Jour. - Engineering and Mining Journal. McGraw-Hill Publishing Co., New York, N.Y.

Franklin Inst. Jour. - Journal of the Franklin Institute. Philadelphia, Pa.

Geochim. et Cosmochim. Acta - Geochimica et Cosmochimica Acta. Pergamon Press, London, England. 
Geol. Soc. America Bull. - Geological Society of America Bulletin. Boulder, Colo.

Geol. Soc. America Proc. - Geological Society of America Proceedings. Boulder, Colo.

Gulf Coast Assoc. Geol. Socs. Trans. - Gulf Coast Association of Geological Societies Transactions. New Orleans, La.

Hopper. See Oklahoma Geology Notes.

Indus. and Fng. Chemistry - Industrial and Engineering Chemistry. American Chemical Society, Washington, D.C.

Inst. Petroleum Jour. - The Institute of Petroleum Journal. London, England.

Internat. Geol. Congress, 20th, Mexico City, 1956, Rept. - International Geological Congress, Report of the 20th Session. Mexico City, Mexico.

Interstate Oil. Compact Comm. Committee Bull. - Interstate Oil Compact Commission Committee Bulletin. Oklahoma City, Okla.

Jour. Alberta Soc. Petroleum Geologists. See Bull. Canadian Petroleum Geology.

Jour. Canadian Petroleum Technology - The Journal of Canadian Petroleum Technology. The Petroleum Society of C.I.M.M. The Canadian Institute of Mining and Metallurgy. Montreal, Quebec, Canada.

Jour. Geology - Journal of Geology. University of Chicago Press. Chicago, Ill.

Jour. Petroleum Technology - Journal of Petroleum Technology. Society of Petroleum Engineers of the American Institute of Mining, Metallurgical, and Petroleum Engineers. Dallas, Tex.

Jour. Sed. Petrology - Journal of Sedimentary Petrology. Society of Economic Paleontologists and Mineralogists. A Division of The American Association of Petroleum Geologists. Tulsa, Okla.

Kansas Geol. Survey Bull. - State Geological Survey of Kansas Bulletin. University of Kansas. Lawrence, Kans.

Kentucky Geol. Survey Bull. - Kentucky Geological Survey Bulletin. University of Kentucky. Lexington, $\mathrm{Ky}$.

Kentucky Geol. Survey [Rept.] — Kentucky Geological Survey [Report]. University of Kentucky. Lexington, $\mathrm{Ky}$.

Kentucky Geol. Survey Rept. Progress - Kentucky Geological Survey Report of Progress. Lexington, Ky.

Los Angeles County Mus. Contr. Sci. - Los Angeles County Museum Contributions in Science. Los Angeles, Calif.

Los Angeles Mus. Pub. See Los Angeles County Mus. Contr. Sci.

Michigan Geol. Survey Pub. See Michigan Geol. Survey Bull.

Michigan Geol. Survey Bull. - Michigan Geological Survey Bulletin. Lansing, Mich.

Mines and Minerals - Mines and Minerals. Scranton, Pa., and Denver, Colo.

Mining and Metallurgy. See Mining Engineering.

Mining Eng. - Mining Engineering. American Institute Mining, Metallurgical, and Petroleum Engineers. New York, N.Y.

Mississippi Geol: Econ. and Topog. Survey Bull.-Mississippi Geological, Economic and Topographical Survey Bulletin. Jackson, Miss.

Mississippi Geol. Survey Bull. See Mississippi Geol. Econ. and Topog. Survey Bull.

Missouri Bur. Geology and Mines [Rept.] See Missouri Div. Geol. Survey and Water Resources [Rept.]. 
Missouri Div. Geol. Survey and Water Resources Inf. Circ. - Missouri Division of Geological Survey and Water Resources Information Circular. Rolla, Mo.

Missouri Div. Geol. Survey and Water Resources [Rept.] - Missouri Division of Geological Survey and Water Resources [Report]. Rolla, Mo.

New Mexico Bur. Mines and Mineral Resources Bull. - New Mexico Bureau of Mines and Mineral Resources Bulletin. New Mexico Institute of Mining and Technology. Socorro, N. Mex.

Ohio Div. Geol. Survey Bull. - Ohio Division of Geological Survey Bulletin. Columbus, Ohio.

Ohio State Geologist Rept. See Ohio Div. Geol. Survey Bull.

Oil and Gas Jour. - Oil and Gas Journal. Petroleum Publishing Company. Tulsa, Okla.

Oil Weekly. See World Oil.

Oklahoma Geol. Survey Bull. - Oklahoma Geological Survey Bulletin. Norman, Okla.

Oklahoma Geol. Survey Circ. - Oklahoma Geological Survey Circular, Norman, Okla.

Oklahoma Geol. Survey Map - Oklahoma Geological Survey Map. Norman, Okla.

Oklahoma Geol. Survey Mineral Rept.-Oklahoma Geological Survey Mineral Report. Norman, Okla.

Oklahoma Geology Notes - Oklahoma Geology Notes. Oklahoma Geological Survey. University of Oklahoma. Norman, Okla.

Research Council Alberta Circ. - Research Council of Alberta Circular. Edmonton, Alberta, Canada.

Research Council Alberta Inf. Ser. - Research Council of Alberta Information Series. Edmonton, Alberta, Canada.

Research Council Alberta Mem.-Research Council of Alberta Memoir. Edmonton, Alberta, Canada.

Research Council Alberta Rept. - Research Council of Alberta Report. Edmonton, Alberta, Canada.

Royal Soc. Canada Trans. - Transactions of the Royal Society of Canada. Ottawa, Ontario, Canada.

Saskatchewan Dept. Mineral Resources Rept. - Saskatchewan Department of Mineral Resources Report. Regina, Saskatchewan, Canada.

Sci. American - Scientific American. Scientific American, Inc. New York, N.Y.

Sci. Monthly. See Science.

Science-Science. American Association for the Advancement of Science. Washington, D.C.

Soc. Petroleum Engineers A.I.M.E. Trans.-Transactions of the Society of Petroleum Engineers of the American Institute of Mining, Metallurgical, and Petroleum Engineers. Dallas, Tex.

Tennessee Div. Geology Bull. - Tennessee Division of Geology Bulletin. Tennessee Department of Conservation. Nashville, Tenn.

Texas Geol. Survey Ann. Rept.-Texas Geological Survey Annual Report. Austin, Tex.

Texas Univ. Bur. Econ. Geology Mineral Resource Survey Circ.-University of Texas Bureau of Economic Geology Mineral Resource Survey Circular. Austin, Tex.

Texas Univ. Mineral Survey Bull. See Texas Univ. Pub. 
Texas Univ. Pub.-The University of Texas Publication. The University of Texas, Bureau of Economic Geology. Austin, Tex.

U.S. Bur. Mines Inf. Circ.-United States Bureau of Mines Information Circular. Washington, D.C.

U.S. Bur. Mines Minerals and Geology Work Group Rept.-U.S. Bureau Mines Minerals and Geology Work Group Report. Washington, D.C.

U.S. Bur. Mines Mon.-United States Bureau of Mines Monograph. Washington, D.C.

U.S. Bur. Mines Rept. Inv.--United States Bureau of Mines Report of Investigations. Washington, D.C.

U.S. Bur. Mines Tech. Paper-United States Bureau of Mines Technical Paper. Washington, D.C.

U.S. Geol. Survey Ann. Rept.-United States Geological Survey Annual Report. Washington, D.C.

U.S. Geol. Survey Bull. - United States Geological Survey Bulletin. Washington, D.C.

U.S. Geol. Survey Geol. Quad. Map-United States Geological Survey Geologic Quadrangle Map. Washington, D.C.

U.S. Geol. Survey Geologic Atlas-United States Geological Survey Folios of the Geologic Atlas of the United States. Washington, D.C.

U.S. Geol. Survey Mineral Resources of the United States-United States Geological Survey Mineral Resources of the United States. Washington, D.C.

U.S. Geol. Survey Missouri River Basin Studies Map-United States Geological Survey Missouri River Basin Interagency Committee. Washington, D.C.

U.S. Geol. Survey Oil and Gas Inv. Chart-United States Geological Survey Oil and Gas Investigations Chart. Washington, D.C.

U.S. Geol. Survey Oil and Gas Inv. Map-United States Geological Survey Oil and Gas Investigations Map. Washington, D.C.

U.S. Geol. Survey Prof. Paper-United States Geological Survey Professional Paper, Washington, D.C.

U.S. Senate Doc.-United States Senate Document. Washington, D.C.

Utah Acad. Sci., Arts and Letters Proc.-Proceedings of the Utah Academy of Sciences, Arts, and Letters. Provo, Utah.

Utah Geol. and Mineralog. Survey Bull.-Utah Geological and Mineralogical Survey Bulletin. University of Utah, College of Mines and Mineral Industries. Salt Lake City, Utah.

Utah Geol. and Mineralog. Survey Map-Utah Geological and Mineralogical Survey Map. University of Utah, College of Mines and Mineral Industries. Salt Lake City, Utah.

Utah Geol. and Mineralog. Survey Spec. Studies - Utah Geological and Mineralogical Survey Special Studies. University of Utah, College of Mines and Mineral Industries. Salt Lake City, Utah.

Virginia Univ. Philosophical Soc. Bull. - Virginia University Philosophical Society Bulletin. Charlottesville, Va.

Washington Acad. Sci. Jour.-Journal of the Washington Academy of Sciences. Washington, D.C.

West Virginia Geol. Survey County Repts. - West Virginia Geological Survey County Reports. Wheeling, W. Va.

World Oil-World Oil. Gulf Publishing Company. Houston, Tex.

Wyoming Geol. Survey Bull.-Wyoming Geological Survey Bulletin. University of Wyoming, Laramie, Wyo. 



\section{GENERAL REFERENCE PUBLICATIONS}

\section{SUBJECT INDEX}

Analyses

Clerc, R. J., and O'Neal, M. J., Jr., 1960

Erickson, R. L., Myers, A. T., and Horr, C. A., 1954

Hail, W. J., Jr., Myers, A. T., and Horr, C. A., 1956

Coal

Exploration

Cameron, R. J., 1968

Geochemistry

Taylor, F. B., 1967

Composition of asphalt

Baker, E. G., 1962

Ball, J. S., Whisman, M. L., and Wenger, W. J., 1951

Bell, K. G., 1960

Betts, R. L., and Wirsig, H. D., 1943

Bonham, L. C., 1956

Clerc, R. J., and O'Neal, M. J., 1960

Erickson, Theodore, 1918

Hodgson, G. L., and Baker, B. L., 1957

Hubbard, R. L., and Stanfield, K. E., 1948

Katz, D. I., and Beu, K. E., 1945

Knowles, E. C., and Levin, Harry, 1941

LeMaire, G. W., 1953

Martin, R. L., Winters, J. C., and Williams, J. A., 1963

Moore, J. W., and Dunning, H. N., 1957

O'Donnell, Gordon, 1951

Shirey, W. B., 1931

Thode, H. G., Monster, Jan, and Dunford, H. B., 1958

Thurston, R. R., and Knowles, E. C., 1941

Traxler, R. N., 1961

Witherspoon, P. A., and Winniford, R. S., 1967

Physical properties of asphalt

Beal, Carlton, 1946

Bencowitz, I., and Boe, E. S., 1936

Clarke, F. W., 1924

Eckert, G. W., and Wectman, B., 1947

Henderson, J. H., and Weber, L., 1965

Hoiberg, A. J., and Garris, W. E., 1944

Holmes, A., Collins, J. O., and Child, W. C., 1936

Hubbard, R. L., and Stanfield, K. E., 1949

Nevitt, H. G., and Krchma, L. C., 1937

Oliensis, G. L., 1933

Saal, R. N. J., Heukelom, W., and Blokker, P. C., 1940 
Geochemistry-Continued

Physical properties of asphalt - Continued

Saal, R. N. J., Meinema, K., and Blokker, P. C., 1940

Schweyer, H. E., Coombs, C. E., and Traxler, R. N., 1936

Spencer, G. B., Eckard, W. E., and Johnson, F. S., 1969

Stanfield, K. E., and Hubbard, R. L., 1949a

Stanfield, K. E., and Hubbard, R. L., 1949b

Thurston, R. R., and Knowles, E. C., 1936

Traxler, R. N., and Schweyer, H. E., 1936

Gilsonite

Young, R. S., 1954

Cottingham, P. L., Tihen, S. S., Brown, J. F., Kindschy, E. O., Jr.,

Kelley, R. E., Schunter, W. E., and Murphy, W. I. R., 1955

Erickson, Theodore, 1918

Richardson, Clifford, 1916

Grahamite

Clarke, F. W., 1924

Richardson, Clifford, 1916

Humic acids

Haseman, J. D., 1921

Manufactured asphalt

LeMaire, G. W., 1953

Nickel

Oil shale

Hodgson, G. W., and Baker, B. L., 1957

Cameron, R. J., 1968

Hartley, F. L., and Brinegar, C. S., 1957

Oil seeps

Link, W. K., 1952

Origin

Baker, E. G., 1960

Haseman, J. D., 1921

Haseman, J. D., 1930

Powers, Sidney, and Clapp, F. G., 1932

Rubey, G. M., 1923

White, David, 1915

Petroleum technology

Porphyrins

Henderson, J. H., and Weber, L., 1965

Dunning, H. N., Moore, J. W., Myers, A. T., 1954

Hodgson, G. W., and Baker, B. L., 1957

Radioactivity

Bell, K. G., Goodman, Clark, and Whitehead, W. L., 1940

Breger, I. A., and Whitehead, W. L., 1951

Recovery methods

Howard, J. V., 1965

Landrum, B. L., Smith, J. E., and Crawford, P. B., 1960

Oil and Gas Journal, 1964

Reed, R. L., Reed, D. W., and Tracht, J. H., 1960

Spencer, G. B., Eckard, W. E., and Johnson, F. S., 1969

Szasz, S. E., and Thomas, G. W., 1965

World Oil, 1964 
Resources

Ayres, Eugene, and Scarlott, C. A., 1952

Dietzman, W. D., Carrales, M., and Jirik, C. J., 1965

Duncan, D. C., 1951

Duncan, D. C., 1960

McKelvey, V. E., and Duncan, D. C., 1967

Phizackerley, P. H., and Scott, L. O., 1967

Spencer, G. B., Eckard, W. E., and Johnson, F. S., 1969

U.S. Bureau of Mines, 1967

Uranium

U.S. Geological Survey, 1951

Bell, K. G., 1960

Erickson, R. L., Myers, A. T., and Horr, C. A., 1954

Hail, W. J., Jr., 1957

Hail, W. J., Jr., Myers, A. T., and Horr, C. A., 1956

Vanadium

Hyden, H. J., 1956

Bird, R. M., and Calcott, W. S., 1914

Hodgson, G. W., and Baker, B. L., 1957

Hyden, H. J., 1956

\section{AUTHOR LIST}

Ayres, Eugene, and Scarlott, C. A., 1952, Energy sources - the wealth of the World: New York, McGraw Hill, Inc., 344 p. [p. 74-76].

The largest known deposit of tar in North America is the Athabaska deposit in northern Alberta. The highest estimate of fuel content of this deposit is 500 billion barrels. The highest estimate for fuel content of tar deposits in the U.S. is 5 billion barrels. Most of this is in the Uinta Basin of Utah, with about one-tenth as much in California.

Baker, E. G., 1960, A hypothesis concerning the accumulation of sediment hydrocarbons to form crude oil: Geochim. et Cosmochim. Acta, v. 19, no. 4 , p. 309-317.

Small amounts of hydrocarbons, similar to those present in petroleum, are known to be dispersed throughout Recent marine sediments. Their importance as major constituents of crude oil is still being debated. It is significant that crude oils and the sediments being deposited today contain certain identical kinds of hydrocarbons. From an awareness of this close relationship and from a knowledge of the distributional differences which exist between Recent sediments and crude oil hydrocarbons, the process of forming oil appears mainly to be a physical one. Consequently, no extensive chemical alterations would be required by this hypothesis. A study of hydrocarbon solubility in dilute colloidal electrolyte solutions suggested the nature of the physical process by which sediment hydrocarbons may be selectively removed from the source sediments and deposited in the correct proportions to form crude oil. The process appears to involve the solution, migration, and release of hydrocarbons in waters containing natural solubilizers. The similarity between the relative abundance of certain hydrocarbons in crude oil and the relative solubility of the same hydrocarbons in colloidal electrolyte solutions provides presumptive evidence that crude oils consist of Recent sediment hydrocarbons that were once solubilized in formation waters. Author's abstract. 
Baker, E. G., 1962, Distribution of hydrocarbons in petroleum: Am. Assoc. Petroleum Geologists Bull., v. 46, no. 1, p. 76-84.

Most hydrocarbons in the gasoline range of petroleum have either a monomodal or a bimodal lognormal distribution. All the very water soluble hydrocarbons $\left(\mathrm{C}_{5}\right.$ and below), however, are normally distributed. The distribution of hydrocarbons in petroleum appears to reflect variations in the kind and size of the micelles in which hydrocarbons selectively dissolve. The subsequent release of the solubilized hydrocarbons from aqueous solution results in the formation of crude-oil droplets. Such a geochemical process of oil formation explains the characteristic proportions of certain homologous and isometric hydrocarbons present in a particular crude oil; it also accounts for the statistical nature of the variation in their absolute amounts - from one crude oil to another. Author's abstract condensed.

Ball, J. S., Whisman, M. L., and Wenger, W. J., 1951, Nitrogen content of crude petroleums: Indus. and Eng. Chemistry, v. 43, no. 11, p. 2577-2581.

Nitrogen contents of 153 crude petroleums from all parts of the United States were investigated in this study. In general, the more asphaltic crude oils contained the higher nitrogen, and the bulk of the nitrogen was in the high-molecular-weight portion of the oils. Correlations were developed between the Conradson carbon residue of the oil and the nitrogen content for oils from particular geological periods. Correlations of nitrogen content with geologic age may give clues as to the origin and process of conversion of petroleum. Authors' abstract condensed.

Beal, Carlton, 1946, The viscosity of air, water, natural gas, crude oil, and its associated gases at oil-field temperatures and pressures: Am. Inst. Mining Eng. Trans., v. 165, p. 94-115.

This paper contains charts for conversion of various viscosimeter units into centipoises and graphically summarizes published investigations of the viscosity of air, water, and natural gas at high temperatures and pressures. Where possible, charts and correlations were constructed to cover a range of temperature $\left(60^{\circ}-300^{\circ} \mathrm{F}\right)$ and pressure $(14.7 \mathrm{lbs} / \mathrm{sq}$. in. abs. to $8,000 \mathrm{lbs} / \mathrm{sq}$. in. gauge) encountered in oil fields. Correlation charts were constructed from an analysis and correlation of 1,332 viscosity and solubility observations from 953 crude-oil samples taken from 747 oil fields. Results show that crude-oil viscosity at various reservoir conditions can be predicted, with average deviations varying from 24.2 percent for gas-free crude oil to as little as 2.7 percent for undersaturated crude oil "above the bubble point." The solubility of crude oil may be predicted from oil gravity and saturation pressure, with an average deviation of 22.0 percent from observed values. In conclusion, it is shown that the viscosity of a gas and gas-saturated crude oil may be predicted within the accuracy of most reservoir computations. Author's abstract condensed.

Bell, K. G., 1960, Uranium and other trace elements in petroleum and rock asphalts: U.S. Geol. Survey Prof. Paper 356-B, p. 45-65 [1961].

Uranium is a minor trace-element constituent of petroleums and their natural derivatives. The average uranium content for all crude oil is estimated to be about 1 part per billion, or about one-third that of the average content of sea water. Mixed-base and asphalt-base crude oils, in general, contain a slightly greater quantity of uranium than paraffin-base crude oils. There is a 
rough positive correlation between specific gravity and uranium content. Crude oils from one region are no more uraniferous than those from any other, except perhaps as a result of local predominance of heavy aromatic and asphaltic constituents. The bituminous constituents of rock asphalts contain as much as a few thousand parts per billion of uranium, the average being about $1,000 \mathrm{ppb}$, a concentration that is about a thousandfold increase over that in crude oils and probably a somewhat smaller increase over that in petroleums. It is believed that the bitumens extract uranium from the host rocks. There seems to be a positive correlation between the uranium content of the bitumens and that of the host rocks. Crude oil is not a practical source material for uranium; the total uranium content of the crude-oil reserves of the United States does not exceed 5 tons. The bitumens of the rock asphalt deposits of the United States contain several hundred tons of uranium, but, because they are dispersed in several billion tons of rock, they are not practical source materials for uranium. Author's abstract condensed.

Bell, K. G., Goodman, Clark, and Whitehead, W. L., 1940, Radioactivity of sedimentary rocks and associated petroleum: Am. Assoc. Petroleum Geologists Bull., v. 24, no. 9, p. 1529-1547.

Determinations of the radioactivity of 21 sedimentary rocks and seven associated crude oils have been made by the precision method developed by R. D. Evans. The specimens consisted of cuttings and cores from wells in the Bartlesville, Cromwell, Frio, Woodbine, and Viola-Simpson formations. Considerable variability in radioactivity was found in the sandstones (1.4 to $\left.0.19 \times 10^{-12} \mathrm{~g} \mathrm{Ra} / \mathrm{g}\right)$ and limestones $\left(1.3\right.$ to $\left.0.18 \times 10^{-12} \mathrm{~g} \mathrm{Ra} / \mathrm{g}\right)$. The radium content of limestones decreases with increasing purity. The shales were uniform (1.2 to $\left.1.0 \times 10^{-12} \mathrm{~g} \mathrm{Ra} / \mathrm{g}\right)$. Apparently, discrete mineral particles in sandstone and impurities in limestone account for their occasional high radioactivity. The radon content of the crude oils was in one sample 38 times, and for all samples averaged 10 times, the amount being in equilibrium with the radium present. The results corroborate the inferences of former investigators that radon tends to concentrate in crude oils. Authors' abstract condensed.

Bencowitz, I., and Boe, E. S., 1936, Change of penetration with temperature of various asphalts: Indus. and Eng. Chemistry, Anal. Ed., v. 8, no. 3, p. 157-162.

The susceptibility of asphalts to temperature changes is probably the most important characteristic of these substances. To be able to evaluate this coefficient with precision is essential. In this investigation, a simple equation, $p=A+B \times C t$, was found to express the variation of the penetration of 13 asphalts with the temperature, where $p$ is the penetration, in decimillimeters; $t$, is the temperature, in degrees Centigrade; and $A, B$, and $C$ are constants characteristic of each asphalt. The equation can be solved when three penetrations obtained with the same weight and for the same period of time at different temperatures are known. By means of this equation, a simple index, $p_{2}-p_{1}$, was found to represent adequately the order and the relative magnitude of the temperature and susceptibility of the 13 asphalts. Authors' abstract condensed.

Betts, R. L., and Wirsig, H. D., 1943, Determination of wax in asphalt: Indus. and Eng. Chemistry, Anal. Ed., v. 15, p. 478-483. 
The sulfuric acid and aluminum chloride treating methods each yield producible results, and either method would serve to classify asphalt with respect to both quantity and melting point of waxes present. The acid method, however, gave higher yields of wax, sometimes nearly twice as great, and the melting points were nearly always lower than those obtained by the aluminum chloride method. Preliminary work indicated that sulfuric acid was prone to react with wax and resins, giving sulfonated products that did not possess sharp melting points. On treating with aluminum chloride no particular difficulty was noted with any of the asphalts examined. Both methods indicate that asphalts contain larger amounts of waxes having higher melting points than can be obtained by the Holde procedure.

Bird, R. M., and Calcott, W. S., 1914, The association of vanadium with petroleum and asphalt: Virginia Univ. Philosophical Soc. Bull., v. 1, no. 18, p. $365-371$.

The results of the authors' experiments led them to conclude that the association of petroleum with vanadium compounds and of asphalt with vanadium ores may come about in the following way: Vanadates in solution in ground water come in contact with oils bearing hydrogen sulfide, and yield vanadium sulfide. This finely divided vanadium sulfide may travel with the oil, and be deposited when meeting carbon dioxide. Precipitated vanadium sulfide and atmospheric oxygen may change the accumulating mass of oil into asphalt. This sequence of events involves the usual occurrences of materials and conditions - vanadates and carbon dioxide dissolved in ground waters, oil containing hydrogen sulfide, and conditions permitting the oxidation of accumulating petroleum with the aid of vanadium oxide acting as an oxygen carrier. Authors' text condensed.

Bonham, L. C., 1956, Geochemical investigation of crude oils: Am. Assoc. Petroleum Geologists Bull., v. 40, no. 5, p. 897-908.

A spectrochemical study was made of 66 crude-oil samples from different parts of the United States to investigate the geologic significance of trace metals in oils. Among the oils analyzed, those from some basins contain distinctively different trace-metal suites, but oils from basins of similar age and environment do not show characteristic differences. A detailed study was made of Lower Pennsylvanian oils from the Seminole area, Okla. The traceelement content of these oils did not serve to correlate producing strata from pool to pool or to differentiate producing strata. However, the areal distribution of vanadium and nickel concentrations in the Seminole area is closely related to paleogeographic trends - the concentrations are greatest near the shoreline and decrease basinward. The decrease in concentration may be attributed to adsorption of the polar-metal-bearing organic constituents during migration or to different metal contents of oils that originated in different parts of the basin. Author's abstract.

Breger, I. A., and Whitehead, W. L., 1951, Radioactivity and the origin of petroleum: World Petroleum Congress Proc., 3d, sec. 3, p. 421-427.

Since 1942 the American Petroleum Institute has sponsored a project at the Massachusetts Institute of Technology to investigate the effect of radioactivity on the transformation of marine organic materials into petroleum hydrocarbons. To date it has been possible to (1) convert fatty acids into 
aliphatic hydrocarbons; (2) convert a naphthenic acid into a cyclic hydrocarbon by means of alpha-particle bombardment; and (3) produce gaseous hydrocarbons found in association with crude oils. Work is being carried out to determine the relationship between the organic matter and radioactive elements in marine organic shales. Studies have also been carried out to establish the radioactivity of a number of important geological strata associated with crude oils. Authors' text condensed.

Cameron, R. J., 1968, A comparative study of oil shale, tar sands, and coal as sources of oil, in Symposium on petroleum economics and evaluation: Soc. Petroleum Engineers of A.I.M.E., Dallas, Texas, 1968, 28 p.

Comparing the technologies of each potential source of synthetic fuels reveals two significant features: (1) They all involve large-scale low-cost mining of a relatively low-valued mineral. (2) The "hydrocarbons" in each instance are hydrogen-deficient and contain substantial percentages of sulfur, nitrogen, and oxygen; thus, hydrogenation is a common technology, and the cost of hydrogen is a significant economic factor. New technology is now being developed for oil shale and coal primarily in the liquefaction step; tar-sands technology uses conventional mineral-processing techniques and equipment. In-situ oil recovery is most likely for tar sands, more difficult for oil shale, and quite unlikely for coal. Commercial production from oil shale and coal is 5 to 10 years away. Only tar-sands processing is sufficiently advanced to contribute significantly to the North American petroleum supply during the next decade. Author's summary condensed.

Clarke, F. W., 1924, The natural hydrocarbons, in The data of geochemistry: U.S. Geol. Survey Bull. 770, 841 p. [p. 731-755].

The solid hydrocarbons found in nature are generally not given specific names, but are known generically as asphalt or bitumen. The pasty, viscid varieties are called maltha. There are also mixtures of these substances with sandstones, shales, and limestones forming asphalt rocks from which oil or tar can be separated by distillation or melting. The exact nature of these hydrocarbons is yet to be determined. Some authors attribute them to the oxidation of lighter oils; others regard them as residues from a natural distillation of the petroleum. The oxidation theory is borne out by the fact that in an experiment aspirating air through Pennsylvania petroleum for several hours the petroleum was partly converted to a substance resembling grahamite.

Clerc, R. J., and O'Neal, M. J., Jr., 1960, The mass spectrometric analysis of asphalt-A preliminary investigation: Anal. Chemistry, v. 33 , no. 3, p. 380-382.

A preliminary investigation has indicated that mass spectometric techniques can be applied to the analysis of asphalt and other residual petroleum fractions. Although the individual mass peaks were not resolved above mass 600 , a molecular-weight distribution of the unresolved peaks was obtained. Some insight into the composition of asphalt from straight-run residue was gained. This particular sample of asphalt had a molecular-weight range of 500 to 1,900, and a mean value of about 900. Fragment ions indicated that certain heterocyclic and aromatic nuclei were the predominant molecular structural groups. Authors' abstract condensed. 
Cottingham, P. L., Tihen, S. S., Brown, J. F., Kindschy, E. O., Jr., Kelley, R. E., Schunter, W. E., and Murphy, W. I. R., 1955, Gilsonite as a source of synthetic fuels: Indus. and Eng. Chemistry, v. 47, no. 2, p. 328-332.

Distillate prepared by coking gilsonite is similar in many respects to distillate prepared by coking N-T-U shale oil, but it contains considerably less sulfur. Its high pour point might be troublesome in pipeline transportation. The straight-run naphtha fraction could be used in gasoline blends after mild chemical treatment to reduce gum and improve stability and color. The straight-run, high-boiling fraction would be a poor diesel fuel stock and, because of its high nitrogen content, probably a poor catalytic cracking stock. It can be hydrogenated, under relatively mild conditions, to an ultimate yield of approximately 85 percent of stable low-sulfur naphtha that, on blending with less than 3 milliliters of tetraethyllead per gallon, will have octane numbers high enough to meet regular-grade-gasoline specifications. There are insufficient quantities of $\mathrm{C}_{4}$-plus hydrocarbons in the gas formed in the two hydrogenation steps to blend the combined naphthas to a Reid vapor pressure of 10 pounds per square inch. The boiling-range distribution of the combined naphthas produced in these experiments is such that they might also require blending with other stocks to produce desirable volatility characteristics. Even after two passes through the hydrogenation unit, the portion of the product boiling above the naphtha range appears to have few poor diesel-fuel properties. Authors' conclusions.

Dietzman, W. D., Carrales, M., and Jirik, C. J., 1965, Heavy crude oil reservoirs in the United States - A survey: U.S. Bur. Mines Inf. Circ. 8263, $53 \mathrm{p}$.

This report was prepared to present general information on more than 2,000 heavy-oil reservoirs in more than 1,500 fields in 26 States. Information on each heavy-oil deposit includes field and formation, location, average or range of depth, average API gravity of oil, average thickness of formation, areal extent of field, total productive wells drilled in field, discovery date of field, field status in 1963, cumulative production to January 1, 1964, and all known types of secondary-recovery operations initiated (active and terminated) in the reservoirs. As of January 1, 1964, 75 percent of the heavy-oil reservoirs in the United States had produced more than 10 billion barrels of oil and are estimated to contain over 90 billion barrels of oil in place. It is also estimated that if the derosits which have had little or no production, such as the one in Missouri, were included, the total amount of heavy oil in reservoirs would exceed 150 billion barrels. Authors' abstract condensed.

Duncan, D. C., 1951, Bituminous rock and related asphaltic deposits, in Fuel resources of the United States - A statement prepared by the U.S. Geological Survey at the request of the Committee on Interior and Insular Affairs, U.S. Senate, 82d Cong., 1st sess., Cong. Doc. 80424, p. 38-39.

Production of asphalt in the United States was mainly from natural asphalt or bituminous-rock deposits until about 1907, when refinery residues from petroleum became the chief source. Total production of natural asphalt and bituminous rock in the United States has been on the order of magnitude of 20 million tons containing possibly 1.5 million tons of bitumen, and the 
total gilsonite production has been about 1.6 million tons. This report contains reserve figures for the deposits at Vernal and Sunnyside, Utah; Edna, Santa Cruz, and McKittrick, Calif.; and Uvalde, Tex. Author's text condensed.

Duncan, D. C., 1960, Resources of coal, petroleum, natural gas, oil shale, and tar sands in the United States and Allied and neutral countries: Prepared by the Joint Committee on Atomic Energy, United States Congress, Cong. Doc. 1507, p. 1536-1547.

In the United States, selected tar-sand resources in Utah, Texas, and California are estimated to contain about 2 to 3 billion barrels of bitumen in near-surface parts of the deposits; and about 10 billion barrels has been postulated for the entire United States. The Athabaska tar sands in Alberta, Canada, have been estimated to contain 300 billion barrels of oil. Report tabulates coal, petroleum, natural gas, oil shale, and tar-sand resources.

Dunning, H. N., Moore, J. W., and Myers, A. T., 1954, Properties of porphyrins in petroleum: Indus. and Eng. Chemistry, v. 46, no. 9, p. 20002009.

A heavy California crude oil was subjected to a water-spray extraction procedure supplemented by solvent extraction. The pentane extraction of the water-spray extract accomplished a considerable concentration of the ash, nickel, vanadium, and porphyrin contents of the crude oil. In the final pentane-insoluble portion of the water-spray extract, the concentrations of ash, nickel, vanadium, and porphyrin aggregate were respectively, 35.4, 4.8, 4.9, and 3.2 times the concentration of these constituents in the original crude oil. The water-spray extraction procedure is accompanied by a decrease in the interfacial activity of the crude oil and an increase in the interfacial activity and film formation of the extract. The interfacial activities of the various fractions parallel the porphyrin, nitrogen, and metal contents of these fractions. This correlation indicates the important role of these substances in determining the interfacial properties of the crude oil. Author's conclusions condensed.

Eckert, G. W., and Wectman, B., 1947, Mean molecular weights of asphalts and their constituents: Indus. and Eng. Chemistry, v. 39, no. 11, p. 15121516.

The molecular-weight method based on the viscosity of dilute solutions was investigated for its applicability to asphalts and their constituents. The values for $n s p / c$ and $\log n r / c$ for oils and resins do not change appreciably with increase in concentration, but values for asphaltenes show a gradual increase in $n s p / c$ and $\log n r / c$ with increase in concentration. For concentrations of asphaltenes in benzene less than 1.0 gram per 100 milliliters of benzene, differences between $[\log n r / c] c$ and $[\log n r / c] c=0$ are less than 5 percent of $[\log n r / c] c=0$. The molecular weights of asphaltenes increase with increase in time of air blowing of the original asphalts. Author's summary condensed.

Erickson, R. L., Myers, A .T., and Horr, C. A., 1954, Association of uranium and other metals with crude oil, asphalt, and petroliferous rock: Am. Assoc. Petroleum Geologists Bull., v. 38, no. 10, p. 2200-2218. 
Some crude oil, natural asphalt, and petroliferous rock are appreciably radioactive, but little is known about the actual uranium content and chemical nature of the uranium compound, or compounds, in these materials. Semiquantitative spectrographic analyses of the ash in 29 samples of crude oil, 22 samples of natural asphalt, and 27 samples of oil extracted from petroliferous rock indicate that metals such as vanadium, nickel, copper, cobalt, molybdenum, lead, chromium, manganese, and arsenic are consistently present-at some places in exceptionally high concentrations-in this type of organic matter. The chemical analyses show that the uranium content of crude oil is consistently much lower than the uranium content of the natural asphalt and oil extracted from petroliferous rock. The uranium content of the ash in these 78 samples ranges from about 0.001 percent to about 10 percent; the uranium content of the total oil or asphalt ranges from less than 0.001 to 32,410 parts per million (3.24 percent). The association of , uranium with organic materials may have a direct bearing on the genesis of some types of uranium deposits. Authors' abstract condensed.

Erickson, Theodore, 1918, The destructive distillation of gilsonite: Utah Acad. Sci., Arts and Letters Proc., v. 1, p. 216-217.

When subjected to destructive distillation at atmospheric pressure, gilsonite yields about 50 percent of its weight in a thin black oil; about 30 percent of its weight appears as gas, and about 20 percent remains in the retort as coke. The gas yields about 0.25 percent of ammonia. Author's text condensed.

Hail, W. J., Jr., 1957, Reconnaissance for uranium in asphalt-bearing rocks in the Western United States: U.S. Geol. Survey Bull. 1046-E, p. 55-85.

An appraisal of asphalt-bearing rocks as potential sources of uranium was made in 45 areas of California, Utah, Wyoming, Montana, New Mexico, Texas, Oklahoma, and Missouri. The oldest rocks sampled are Ordovician in age, and the youngest are Recent. Although none of the deposits are of value at this time as a source of uranium, some of the deposits may constitute a low-grade uranium resource, but recovery of the uranium will depend upon the primary use of the asphalt. Significant amounts of uranium in the ash of oil extracted from these rocks were found in samples from seven of the 45 areas examined. These areas are Chalone Creek, McKittrick, Edna, and Los Alamos, Calif.; Vernal, Utah; Sulphur, Okla.; and Ellis, Mo. Average uranium content of the ash of the extracted oil of samples from these areas ranges from 0.028 to 0.376 percent. All except the Chalone Creek area contain large estimated reserves of asphalt-bearing rock, ranging from 15 million to 2 billion tons. The uranium content of samples from 13 additional areas ranges from 0.020 to 0.068 percent in the ash of the extracted oil. Many of these areas contain very large reserves of asphalt-bearing rock. Most of the asphalt deposits are believed to be oil residues, and the uranium is believed to have been introduced during or after the late stages of oil movement and loss of the lighter fractions. Author's abstract.

Hail, W. J., Jr., Myers, A. T., and Horr, C. A., 1956, Uranium in asphalt-bearing rocks of the Western United States, in Page, L. R., Stocking, H. E., and Smith, H. B., compilers, Contributions to the geology of uranium and thorium by the United States Geological Survey and Atomic Energy Commission for the United Nations International Conference on Peaceful 
Uses of Atomic Energy, Geneva, Switzerland, 1955: U.S. Geol. Survey Prof. Paper 300, 739 p. [p. 521-526].

Asphalt-bearing rocks in $\mathbf{4 5}$ areas in California, Utah, Wyoming, Montana, New Mexico, Texas, Oklahoma, and Missouri were examined as potential sources of uranium. The oldest rocks sampled were Ordovician in age, and the youngest, Recent. Host rocks containing the asphalt include sandstone, arkose, conglomerate, limestone, diatomite, and alluvium. The asphalt was extracted from the host rock, reduced to dry ash, analyzed chemically for uranium, and analyzed spectrographically for other elements by semiquantitative methods. Significant amounts of uranium in the ash of the extracted oil, whose average uranium content ranges from 0.028 to 0.376 percent, were found in samples from seven of the 45 areas examined. All except one area contain large estimated reserves of asphalt-bearing rock, ranging from 15 million to almost 2 billion $\left(10^{9}\right)$ tons. The average uranium content of samples from 13 additional areas ranges from 0.02 to 0.68 percent uranium in the ash of the extracted oil. Many of the areas contain large reserves of asphalt-bearing rock. Most of the uranium present is believed to be an original constituent of the oil or to have been introduced during the migration of the oil. Authors' abstract condensed.

Hartley, F. L., and Brinegar, C. S., 1957, Oil shale and bituminous sand: Sci. Monthly, v. 84, p. 275-289.

The governments of Canada and the United States are sponsoring research to develop the technology to extract oil from both oil shale and bituminous sands. Several private oil companies are also doing research on the problems of processing these two types of deposits. Brazil and the United States have deposits of oil shale large enough to be of worldwide significance. The Green River formation in the Piceance Creek Basin in northwest Colorado contains an estimated 960 billion barrels of shale oil; however, the recoverable reserve is about $65-70$ billion barrels. In the United States there are probably five or six deposits of bituminous sands rich enough (20-40 gallons per ton) to have commercial significance. These are Vernal and Sunnyside, Utah; Uvalde, Tex.; and Edna, Calif. A few other California deposits, including the Sisquoc deposit, are of possible importance. The total quantity of oil contained in these formations is estimated to be 2-3 billion barrels. Thus, in the United States, the bituminous sand reserve is insignificant in comparison to the oil-shale reserve. The Athabaska deposit in northern Alberta is the only bituminous sand deposit large enough to be of worldwide importance. The total reserve for this deposit is 100-300 billion barrels. However, the greatest part of this deposit is beneath 500 to 1,800 feet of overburden, and the amount that can be recovered is debatable. Authors' text condensed.

Haseman, J. D., 1921, The humic acid origin of asphalt: Am. Assoc. Petroleum Geologists Bull., v. 5, no. 1, p. 75-79.

Plants are considered to be the chief source of the hydrocarbons of crude oil. Data on certain swamp materials indicate that asphalt is a derivative of humic acid. The decay of plants in muddy swamps and in coarse sandy swamps is entirely different. In these latter swamps, such as the Okefenokee, decaying plants form humic acids; humic acids incorporate nitrogen and form azohumic acids, which in turn take up some silica and form azo-silico-humic acids. 
Some of these acids form dopplerite, which forms cassel or vandyke brown and asphalt under special conditions. Author's text condensed.

Haseman, J. D., 1930, Origin and environment of source sediments of petroleum deposits: Am. Assoc. Petroleum Geologists Bull., v. 14, no. 11, p. 1465-1468.

Three fundamental geochemical factors are connected with the origin and environment of petroleum deposits: (1) The vast amount of humic acids that are made only in swampy regions where there is more sand than clay; (2) the actual origin of asphalt and hydrocarbons from humic acid in a Florida vandyke-brown lime; and (3) natural activation or energizing of silicon- and carbon-containing materials, which causes them to emit subatomic energy which then produces chemical reactions at ordinary temperatures and pressures by means of specific ions. Author's text condensed.

Henderson, J. H., and Weber, L., 1965, Physical upgrading of heavy crude oils by the application of heat: Jour. Canadian Petroleum Technology, v. 4, no. 4, p. 206-212.

Subjecting a heavy crude oil to mild thermal-cracking conditions effects a permanent and significant reduction in its viscosity and specific gravity. Although all crudes are susceptible to cracking, the temperatures and times required generally exceed those required to crack heavy crudes such as those found in the Athabaska tar sands. For temperatures below $1,000^{\circ} \mathrm{F}$, cracking of both pure hydrocarbons and petroleum can be described by first-order kinetic equations. From laboratory tests on a variety of crude oils, estimates can be made of the time-temperature history necessary to produce specific degrees of viscosity reduction for each. As a result, the feasibility can be estimated of utilizing heat in the reservoir to facilitate the production of heavy oil or of using heat to facilitate the surface handling of oil already produced. The permanent upgrading in physical properties occurs so slowly at $500^{\circ} \mathrm{F}$ that the use of temperatures below this level, as currently practiced with heated pipelines, will effect only a temporary improvement in oil fluidity. At temperatures greater than $700^{\circ} \mathrm{F}$ coking may present serious operating problems, unless residence times are kept very short. Author's abstract condensed.

Hodgson, G. W., and Baker, B. L., 1957, Vanadium, nickel and porphyrins in thermal geochemistry of petroleum: Am. Assoc. Petroleum Geologists Bull., v. 41, no.' 11, p. 2413-2426.

The thermal degradation of compounds containing vanadium and nickel in crude oil has been examined in order to throw light on the significance of trace metals in the geochemistry of petroleum. Almost identical first-orderreaction rates were observed for the removal of the two metals, and extrapolation of the data to geological times and temperatures showed that present-day reservoir temperatures are too low to permit a significant thermal contribution to the changes which appear to have occurred in the maturation of crude oil. A study was made of the degradation of porphyrin compounds which are responsible, in part, for the presence of metals in oil. The rate of the porphyrin degradation at $358^{\circ} \mathrm{C}$ was $0.020 \mathrm{hr}^{-1}$, considerably greater than that for the removal of vanadium, $0.013 \mathrm{hr}^{-1}$ and nickel, $0.012 \mathrm{hr}^{-1}$. The activation energy, which is a measure of the temperature dependence of the reaction, 
was $52.5 \mathrm{Kcal} / \mathrm{mole}$ for porphyrin degradation; $58.6 \mathrm{Kcal} /$ mole for vanadium removal; and $57.5 \mathrm{Kcal} / \mathrm{mole}$ for nickel removal. These data indicate that the spread between porphyrin degradation rates and metal removal rates would increase at all lower temperatures. Consequently, if thermal action were responsible for the maturation of crude oil in nature, the porphyrin material in a maturing oil would be lost very rapidly, as compared with the removal of metals. The relatively constant proportion existing between porphyrin content and metal content found for a widely varying suite of Canadian oils shows that this has, in fact, not happened. This observation tends to confirm the conclusion that thermal action has little to do with the maturation of oil. Authors' abstract.

Hoiberg, A. J., and Garris, W. E., 1944, Analytical fractionation of asphalts: Indus. and Eng. Chemistry, Anal. Ed., v. 16, p. 294-302.

A procedure is described for the solvent separation of asphalts into five fractions: hexane-insolubles, hard resins, soft resins, oils, and waxes. Because all the solvents used boil above room temperature, the method requires only ordinary laboratory glassware. All fractions are recoverable, an advantage in that they may be studied to characterize the asphalt further. The accuracy and precision of the method are discussed. Authors' abstract condensed.

Holmes, A., Collins, J. O., and Child, W. C., 1936, Measuring the susceptibility of asphalts to temperature changes: Indus. and Eng. Chemistry, Anal. Ed., v. 8, no. 2, p. 100-104.

No single factor has thus far been evolved which will adequately express the temperature susceptibility of an asphalt over the wide range of temperatures encountered in the commercial applications of asphalts. A combination of factors or indexes is suggested by which a definite measure of the temperature-susceptibility characteristics of a wide range of asphalts can be determined. The softening-point-penetration index indicates this characteristic for a narrow range of normal atmospheric temperatures, the ratio of penetration at $25^{\circ} \mathrm{C}$ to penetration at $0^{\circ} \mathrm{C}$ at subnormal, and the fluidity index at elevated temperatures. These methods are equally applicable to straight reduced and oxidized asphalts and are easily determined by means of tests which are in common use. Authors' conclusions condensed.

Howard, J. V., 1965, Thermal recovery comes of age: World Oil, v. 160, no. 1, p. 95-104.

Thermal recovery has vast potential. For example, the Athabaska tar sands in Alberta are estimated to contain some 300 billion barrels of oil. This reservoir cannot be produced conventionally at economic rates. However, thermalrecovery techniques make it possible to produce 50-100 billion barrels of this oil. Most major oil provinces contain huge quantities of heavy oil at reasonably shallow depths. There are vast deposits in the Eastern Venezuelan Basin and in Argentina, Canada, and northern Iraq. The famous asphalt ridge of Utah is a major deposit in the United States. Author's text condensed.

Hubbard, R. L., and Stanfield, K. E., 1948, Determination of asphaltenes, oils and resins in asphalt: Anal. Chemistry, v. 20, p. 460-465.

A method is described for the quantitative determination of the three groups of constituents - asphaltenes, oils, and resins - in petroleum and 
native asphalts. The asphaltene (benzene-soluble, pentane-insoluble) fraction is obtained by extracting the asphalt with $n$-pentane. The pentane-soluble portion is further fractionated by adsorption on anhydrous alumina and extraction first with pentane to obtain the oil fraction and then with a methanol-benzene solution to obtain the resin fraction. In contrast to most proposed methods, the three asphalt constituents are recovered and may be used for further study. A complete analysis can be made in one 8-hour day after the sample has been dispersed in pentane and allowed to stand approximately 12 hours, or overnight. Authors' abstract.

Hubbard, R. L., and Stanfield, K. E., 1949, Laboratory study of asphalts from native bitumens and bituminous sandstone: U.S. Bur. Mines Rept. Inv. 4523, 22 p.

Fourteen straight-run asphalts were prepared in the laboratory from bitumens obtained from three sources: (1) Native asphalt from Rozel Point, Utah, (2) bitumen extracted from Athabaska bituminous sandstone at Alberta, Canada, and (3) bitumen extracted from Edna bituminous sandstone outcrops in San Luis Obispo County, Calif. Three to seven asphalts with penetrations ranging from 19 to 287 at $77^{\circ} \mathrm{F}$ were prepared from each bitumen. The yields of the prepared asphalts ranged from 74.5 percent for a 27-penetration asphalt from the Athabaska bitumen to 99.5 percent for a 271-penetration asphalt from the Rozel Point bitumen. The asphalts were further analyzed by separating them quantitatively into asphaltenes, oils, and resins. The asphalts contained 21.0 to 30.4 percent asphaltenes, 29.7 to 48.9 percent oils, and 27.7 to 37.9 percent resins. In general, the characteristics of the asphalts were intermediate between those of the Tampico, Mex., and those of the Kern River, Calif., crude oils and were similar to those made from Oregon Basin, Wyo., crude oils which had been treated previously. Authors' text condensed.

Hyden, H. J., 1956, Uranium and other trace metals in crude oils of the Western United States, in Page, L. R., Stocking, H. E., and Smith, H. B., compilers, Contributions to the geology of uranium and thorium by the United States Geological Survey and Atomic Energy Commission for the United Nations International Conference on Peaceful Uses of Atomic Energy, Geneva, Switzerland, 1955: U.S. Geol. Survey Prof. Paper 300, 739 p. [p. 511-519].

A total of 107 samples of crude oil and 16 samples of oil-refinery residues was collected in the Western United States for uranium and other trace-metal determinations. The crude-oil and refinery residues were converted by ignition to ash. The uranium content was determined fluorimetrically, and the content of vanadium, nickel, and copper was determined spectrographically. Results of the study show that uranium is not preferentially distributed with respect to age, lithologic character, or geographic location of the reservoir rocks, nor does it show any preferential distribution with respect to oil types as established from U.S. Bureau of Mines crude-petroleum analyses. The uranium content of crude oil is insufficient for commercial production, but may serve as a prospecting guide to uranium deposits. Vanadium and nickel are known to exist in crude oils as metallo-organic porphyrin complexes. A comparison of vanadium-nickel and vanadium-uranium ratios in the present investigation shows that most of the uranium is not present as a porphyrin complex in crude oil. Author's abstract. 
Katz, D. L., and Beu, K. E., 1945, Nature of asphaltic substances: Indus. and Eng. Chemistry, v. 37, no. 2, p. 195-200.

Thin films of asphalt and oil have been examined in the electron microscope in a search for colloidal asphaltene particles. These films seem to be free from particles, but numerous particles appear when suspensions of asphalt in benzene and petroleum either are examined. Micrographs at 156,000 diameters indicate asphaltene particles, if present in undiluted oils and asphalt, are less than $65 \mathrm{~A}$ in diameter. Authors' abstract.

Knowles, E. C., and Levin, Harry, 1941, Determination of wax in asphaltic products: Indus. and Eng. Chemistry, Anal. Ed., v. 13, p. 314-317.

This method comprises separating the asphaltene-resin fraction from the oil-wax fraction by hot-liquid propane under pressure and determining the wax in the oil-wax fraction by crystallization at low temperatures from solution in methyl isobutyl ketone (hexone). Hexone possesses the necessary properties of an outstanding reagent for wax determination - namely, high oil-solvent power, low wax-solvent power, and good filtration rates. Authors' abstract condensed.

Landrum, B. L., Smith, J. E., and Crawford, P. B., 1960, Calculations of crude oil recoveries by steam injection: Soc. Petroleum Engineers A.I.M.E. Trans., v. 219, p. 251-256.

A method by which the displacement efficiency of a steam-injection process may be determined is presented in this paper. This method consists of a determination of the position of the steam front at a particular time and the application of the Buckley Leverett theory to the hot and cold regions of the reservoir with the appropriate hot or cold fluid properties. A uniform linearflow system is assumed for this study. The primary properties which affect the results of a steam-injection process are the oil viscosities at steam and reservoir temperatures, injection rate, pay thickness, and oil saturation. The efficiency of steam injection is compared with that of water injection for a 10 -acre, linearly flooded reservoir. In reservoirs where the oil viscosity is about 35 times the water viscosity, the steam process yields recoveries about 20 percent higher than the water flood. Where the oil viscosity is near $500 \mathrm{cp}$, the steam process may recover from three to four times as much oil as a water flood. Authors' abstract condensed.

Le Maire, G. W., 1953, A study of asphalts and asphaltic materials: Colorado School Mines Quart., v. 48, no. 2, 89 p.

This bulletin discusses manufactured asphalts.

Link, W. K., 1952, Significance of oil and gas seeps in world oil exploration: Am. Assoc. Petroleum Geologists Bull., v. 36, no. 8, p. 1505-1540.

A look at the exploration history of the important oil areas of the world proves conclusively that oil and gas seeps gave the first clues to most oilproducing regions. Many great oil fields are the direct result of seepage drilling. Seepages are most numerous in the youngest sediments (especially where they have been folded, faulted, and eroded) and are on the margins of basins. Many seepages are the result of destruction of major accumulations of oil reservoirs. Oil and gas seeps, a prerequisite for a region if it is to produce oil, are indicative of the presence of source rocks. Because large seeps 
generally result from pool destruction, they also indicate reservoir rocks and structure. Recent illustrations of the value of seeps in geologic thinking are the development in western Canada, the Uinta Basin of Utah, and Cuyama Valley in California. This report contains cross sections illustrating the five main types of oil seeps and maps showing worldwide occurrences of oil seeps. Author's abstract condensed.

Martin, R. L., Winters, J. C., and Williams, J. A., 1963, Composition of crude oils by gas chromatography, geological significance of hydrocarbon distribution: World Petroleum Congress Proc., 6th, sec. 5, p. 231-260.

Eighteen crude oils with varying geological histories were analyzed using gas chromatography and supplementary techniques. Individual saturates through $\mathrm{C}_{7}$ and alkylbenzenes through $\mathrm{C}_{10}$ were determined with capillary columns. Normal paraffins through $\mathrm{C}_{35}$ and the $\mathrm{C}_{19}$ and $\mathrm{C}_{20}$ saturated isoprenoid hydrocarbons were determined with packed columns. Also, hydrocarbon types were determined by mass spectrometry in distillation fractions boiling to $430^{\circ} \mathrm{C}$. The data show extremes in composition and define isomer-distribution patterns; these patterns are more complex than commonly suspected. There is an apparent correlation between composition and geological age. Component analyses in the naphtha range cannot be used to predict composition in the gas-oil range. Clues to the origin and maturation of crude oils are discerned. Thermal cracking, rather than catalytic cracking, is suggested as the dominant process in the formation of the naphtha fraction. A variability in source material also is suggested. Oils extracted from source rocks show different hydrocarbon distributions from the crude oils from nearby reservoirs. Authors' abstract condensed.

McKelvey, V. E., and Duncan, D. C., 1967, United States and world resources of energy, in Symposium on the development of petroleum resources of Asia and the Far East, 3d, Tokyo, 1965, Proc.: New York, United Nations, Mineral Resources Devel. Ser. 26, v. 2, p. 9-16.

Domestic resources of the fossil fuels of the types now considered usable contain 950 billion to more than 22 trillion barrels of oil equivalent, and if very low grade organic-rich deposits are included, the potential may be nearly 350 trillion barrels of oil equivalent. World resources contain about 3.9 trillion to more than 80 trillion barrels of oil equivalent, and if very low grade resources are considered, the potential may be about 4.3 quadrillion. In a table called "Provisional Estimates of U.S. Resources of Fossil Fuels," the known recoverable reserves of oil in bituminous rock are listed as $1.3 \times 10^{9}$ barrels. The undiscovered marginal and submarginal resources of oil in bituminous rock is $10 \times 10^{9}$ barrels. Known recoverable resources include minimal estimates of some deposits. Assumed recovery is 50 percent of the oil in place. Authors' text condensed.

Moore, J. W., and Dunning, H. N., 1957, Metal-porphyrin complexes in an asphaltic midcontinent crude oil: U.S. Bur. Mines Rept. Inv. 5370, 24 p.

An extensive laboratory study was made to determine optimum conditions for removing nitrogeneous, metallic, and asphaltic materials from a midcontinent crude oil to precipitation with propane. The propane deasphalting process removes much of the ash, nickel, vanadium, and nitrogen from the oil and markedly decreases the oil's viscosity and carbon residue. Vanadium- 
and nickel-porphyrin complexes were identified in the various extracts and concentrated in the final chromatographic fractions. The amounts of porphyrin complexes in each of the major extracts are roughly proportional to the other polar materials, such as the metals determined and other ash-forming constituents. The presence of these residues of chlorophyll and (or) hemoglobin is indicative of the biological origin of oil. The occurrence of trace metals, such as vanadium and nickel, as stable metal-porphyrin complexes in petroleum stocks prevents their complete removal by usual methods of treatment. However, propane precipitation removes much of the nitrogen, metals, ash-forming materials and metal-porphyrin complexes from the major portion of the crude oil. Therefore, the deleterious effects that these metallic and nitrogeneous substances have on processing and utilization may be minimized by propane-deasphalting processes. Authors' summary condensed.

Nevitt, H. G., and Krchma, L. C., 1937, Effect of temperature on the consistency of asphalts: Indus. and Eng. Chemistry, Anal. Ed., v. 9, no. 3, p. 119-122.

Because the absolute measure of consistency is viscosity, the authors point out that the change in consistency of an asphalt with temperature would be more logically measured as the change of viscosity with temperature. The viscosity-temperature susceptibility coefficient is presented as a more fundamental viscosity-temperature index based on the ASTM viscosity-temperature formula and is mathematically represented as:

$$
S=0.221 \frac{\log \left(\frac{\log \mu_{1}+0.8}{\log \mu_{2}+0.8}\right)}{\log \frac{T_{2}}{T_{1}}},
$$

where $S$ is the viscosity-temperature susceptibility coefficient, and $\mu_{1}$ and $\mu_{2}$ are the kinematic viscosities at absolute temperatures $T_{1}$ and $T_{2}$. Data presented indicate that the viscosity-temperature susceptibility coefficient is applicable to a wide range of temperatures and viscosities. Authors' abstract condensed.

O'Donnell, Gordon, 1951, Separating asphalt into its chemical constituents: Anal. Chemistry, v. 23 , no. 6 , p. 894-898.

The method developed to separate asphalt into its constituent parts involved molecular distillation to yield a size separation. Silica gel chromatography was used to separate saturates, aromatics and resins; solvent dewaxing of the saturates to determine wax content, urea complex formation to separate long-chain paraffins; alumina chromatography to separate monocyclic aromatics; peroxide oxidation followed by chromatography to remove thiophene analogs; and thermal diffusion in the liquid state to segregate naphthenes on the basis of ring number. This method of analysis has proved satisfactory for establishing the concentration of paraffins, naphthenes, aromatics, resins, and asphaltenes in an asphalt, as well as their distribution, on the basis of molecular size. Author's abstract.

Oil and Gas Journal, 1964, Polymers raise waterflood efficiency: Oil and Gas Jour., v. 62 , no. 18 , p. $46-47$.

Dow Chemical Co. and Union Oil Co. developed the "pusher" flood process of heavy-oil recovery. In this process, polymers are added to injection water 
to decrease its mobility to nearly that of the in-place oil. The more favorable water-to-oil mobility ratio results in an improved reservoir sweep. There is a possibility of recovering twice as much oil in some low-gravity fields if the water-soluble polymers are added to the injection fluid.

Oliensis, G. L., 1933, A qualitative test for determining the degree of heterogeneity of asphalts: Am. Soc. Testing and Materials Proc., v. 33, pt. 2, p. 715-728.

A test has been developed for determining qualitatively the degree of physical heterogeneity in asphalt. The test depends upon the precipitation that occurs when such asphalts are dissolved in or dispersed by 5.1 times their volume of certain petroleum naphthas. The term "carbenoids" is proposed as the name of the precipitated bodies. Author's abstract condensed.

Phizackerley, P. H., and Scott, L. O., 1967, Major tar sand deposits of the World: World Petroleum Cong. Proc., 7th, v. 3, p. 551-571.

Details of the stratigraphy, lithology, facies and structure of 20 major tar-sand accumulations, in Canada, Venezuela, Malagasy, U.S.A., Albania, Trinidad, Rumania, and the U.S.S.R. are given, together with reserve figures where known. The relationship of the tar-oil impregnations to the geological setting and presumed origin of the oil are discussed. Only four of the major tar-sand deposits discussed - La Brea (Trinidad), Selenizza (Albania), Derna (Rumania), and Cheildag (U.S.S.R.) - are currently being exploited. The first commercial development of the Athabaska tar sands is scheduled to start in September 1967. Mining will be by the open cast method. The Oficina-Temblador (Venezuela) tar-belt area, the Bemolanga sands (Malagasy), the Utah and some of the California deposits have attracted the interest of oil companies at various times. Steam or hot-water injection or in-situ cracking by fire flooding has been tried with some technical success, but in competition with conventional crudes, their application is as yet uneconomic. Authors' text condensed.

Powers, Sidney, and Clapp, F. G., 1932, Nature and origin of occurrences of oil, gas, and bitumen in igneous and metamorphic rocks: Am. Assoc. Petroleum Geologists Bull., v. 16, no. 8, p. 719-726.

Oil, gas, and residues of petroleum ranging from asphalt to graphite are found in igneous and metamorphic rocks. More than 15 million barrels of oil have been produced from igneous and metamorphic rocks; one gas field produces from a basalt flow, and millions of tons of asphalt, representing the residue of more than 200 million barrels of oil are known in serpentine in northern and northwestern Cuba. Seepages of oil connected with igneous intrusions led to the discovery - in Mexico - of some of the world's largest oil fields. Seepages and traces of oil, gas, and bitumen in igneous rocks point to the possibility of commercial production in many parts of the world where oil has not yet been found.

Reed, R. L., Reed, D. W., and Tracht, J. H., 1960, Experimental aspects of reverse combustion in tar sands: Soc. Petroleum Engineers A.I.M.E. Trans., v. 219 , p. 99 .

In the process known as "forward combustion," the combustion zone advances in a direction which is generally the same as that of the airflow. In 
"reverse combustion," the combustion zone moves in a direction generally opposite that of the airflow. Forward combustion is an ideal combustion process, in that a minimum of the most undesirable fraction of the oil is consumed as fuel in the form of coke, a clean sand is left behind, and generated heat is used as efficiently as possible. However, the applicability of forward combustion is limited. Because the products of combustion, vaporized oil and connate water, must flow into relatively cold regions of the reservoir, there is an upper limit on the viscosity of oil that can be moved by this process. In reverse combustion, the vaporized oil and water, together with the products of combustion, are characteristically produced through sand that is already hot and has had its mobile liquid content eliminated. Thus, there is no upper limit on oil viscosity; indeed, the oil may be an entirely immobile semisolid. However, fuel for the process is an intermediate fraction of the original oil, and the most undesirable fraction remains on the sand surface as a substantial deposit of coke. Authors' text condensed.

Richardson, Clifford, 1916, Gilsonite and grahamite - The result of the metamorphism of petroleum under a particular environment: Indus. and Eng. Chemistry, v. 8, no. 6, p. 493-494.

Gilsonite and grahamite are found in fissure veins which approach the vertical and afford conditions favorable for the metamorphism of petroleum into these materials. Gilsonite is the product of metamorphic changes in petroleum, and grahamite is the product of metamorphic changes in gilsonite. The environment is the governing condition. Under different conditions true asphalt would be formed. Both gilsonite and asphalt have had a common origin in petroleum, but the environments to which they have been subjected have been so different as to result in entirely different products. The bitumen in which gilsonite originated has been confined in narrow veins. Asphalt has spread out horizontally and has been subjected to very different conditions, with the result that the asphalt contains more than 20 percent saturated hydrocarbon, whereas gilsonite and grahamite contain only a relatively small amount. As metamorphism proceeds, there is a gradual decrease in the hydrocarbons and their derivatives, which are soluble in naphtha, and a corresponding increase in the residual coke, which they yield on ignition. Melting point and specific gravity increase correspondingly as the degree of metamorphism increases.

Rubey, G. M., 1923, Peculiar phases of oil saturation in certain sandstones: Am. Assoc. Petroleum Geologists Bull., v. 7, no. 5, p. 473-481.

The lower part of the Green River formation, though devoid of "oil shale," contains several sandstones which show remarkable saturation in some places. This saturation can be found almost entirely around the Uinta Mountains and along the Grand Hogback in Colorado. The conglomerate contains cavities filled with asphaltum in which no sand can be found. The Green River "oil sands" were examined in detail, and a hypothesis for the origin of the "oil cavities" was formed. This hypothesis was based on concurrent deposition of sand and oil. Fresh oil escaping from a seepage floats for a time on the water, the more volatile constituents are lost by evaporation, and the mass sinks and is rolled along by the current. After a flood, the streambed is practically free from "oil rolls," whereas during a period of steady flow, every hole in the stream is floored with oil, and the oil, carried along with the sand and clay, 
is deposited with it. Where oil has escaped in large quantities, there is a constant flow down the stream into the lake or sea; there, it would spread out in the same manner as other sediments. If the oil floated on the surface of the lake or sea, its destination would depend on the prevailing currents and winds. In this manner, a sheet of asphaltum might be deposited in clay and fine sands and not be associated with the sediments carried by the stream which also carried the oil. Author's text condensed.

Saal, R. N. J., Heukelom, W., and Blokker, P. C., 1940, Physical constants of asphaltic bitumens, Pt. 1: Inst. Petroleum Jour., v. 26, no. 195, p. 29-39.

This paper gives a survey of the following physical properties of asphaltic bitumens : specific gravity, coefficient of cubical expansion, specific heat, thermal conductivity, permeability to water vapor, surface tension, and total surface energy. The methods by which these properties were determined are described in detail.

Saal, R. N. J., Meinema, K., and Blokker, P. C., 1940, Physical constants of asphaltic bitumens, Pt. 2: Inst. Petroleum Jour., v. 26, no. 199, p. 246-255.

This paper gives a survey of the following electrical properties of asphaltic bitumens: Dielectric strength, angle of dielectric loss, dielectric constant, and electrical conductivity. The methods by which these properties were determined are described in detail.

Schweyer, H. E., Coombs, C. E., and Traxler, R. N., 1936, The susceptibility of asphalts to temperature change: Am. Soc. Testing and Materials Proc., v. 36 , pt. 2 , p. $531-534$.

At processing temperatures where the asphalts have viscosities ranging from 1 to 5 poises and at service temperatures $\left(15^{\circ}\right.$ to $35^{\circ} \mathrm{C}, 59^{\circ}$ to $\left.95^{\circ} \mathrm{F}\right)$ a $\log$ viscosity versus temperature plot is a straight line, within the limits of experimental error. A new simple and logical way of expressing susceptibility based on the percentage change of viscosity for a $1^{\circ} \mathrm{C}$ rise in temperature is proposed and is called the Asphalt Viscosity Index. Using the Saybolt Furol viscosimeter for measuring consistencies between 1 and 5 posies (approximately 50 to 250 Furol seconds) and the falling coaxial cylinder viscometer for evaluating viscosities at service temperatures $\left(15^{\circ}\right.$ to $35^{\circ} \mathrm{C} ; 59^{\circ}$ to $\left.95^{\circ} \mathrm{F}\right)$, the susceptibility of an asphalt in terms of absolute units can be determined very quickly.

Shirey, W. B., 1931, Metallic constituents of crude petroleum: Indus. and Eng. Chemistry, v. 23, no. 10, p. 1151-1153.

There is a loose quantitative ratio between the vanadium and nickel contents of the petroleum ashes that were analyzed. Nickel apparently occurs to some extent in the ash of all crudes, whereas vanadium appears to associate itself more strictly with the asphaltic crudes. Vanadium may appear in only the most minute traces, or not at all, in some of the paraffin-base crudes. The analysis did not reveal common occurrence of metal in sufficient amounts to make petroleum ash of interest as a source of rarer metals. Author's text condensed.

Spencer, G. B., Eckard, W. E., and Johnson, F. S., 1969, Domestic tar sands and potential recovery methods - A review: Interstate Oil Compact Comm. Committee Bull., v. 11, no. 2, p. 5-12. 
This report reviews and evaluates present knowledge of Unites States tar-sand deposits, including occurrence, physical properties, resources, and recovery methods.

Stanfield, K. E., and Hubbard, R. L., 1949a, Asphalts from Rocky Mountain crude oils - Laboratory preparation and comparison: U.S. Bur. Mines Tech. Paper 717, 77 p.

An apparatus and procedure are described for preparing straight-run asphalts from asphalt-bearing crude oils by distillation at atmospheric and reduced pressure. Crude oils from Wyoming, Arkansas, California, and Montana and from Mexico were used. The yields of the prepared asphalts ranged from 7.8 percent for a 29-penetration asphalt from Wertz, Wyo., to 77.2 percent for a 176-penetration asphalt from Tampico, Mexico. The yields and general properties of straight-run asphalts from different types of crude oils are useful in comparing the properties of the less common asphalts from crude oils of Wyoming and Montana with the properties of commercially important asphalts from other sources. In general, the characteristics of the asphalts from the Wyoming, Arkansas, and Montana crude oils are intermediate between those of the Tampico, Mexico, and the Kern River, Calif., crude oils. Authors' summary condensed.

Stanfield, K. E., and Hubbard, R. L., 1949b, Laboratory study of asphalts from native bitumens and bituminous sandstones: U.S. Bur. Mines Rept. Inv. 4523, 22 p.

Fourteen straight-run asphalts were prepared in the laboratory from bitumens obtained from the following three sources: (1) Native bitumen from Rozel Point, Utah; (2) bitumen extracted from Athabaska bituminous sandstone at Alberta, Canada; and (3) bitumen extracted from Edna bituminous sandstone outcropping in San Luis Obispo County, Calif. The properties of the asphalts were determined by commonly accepted asphalt tests and are tabulated in this report. Authors' summary condensed.

Szasz, S. E., and Thomas, G. W., 1965, Principles of heavy oil recovery: Jour. Canadian Petroleum Technology, v. 4, no. 4, p. 188-195.

The cost of finding new oil reserves has prompted greater interest in the large known deposits of heavy oil on this continent. Because of the high oil viscosities in such reservoirs, recoveries are poor, fluid drives are inefficient, and production rates are uneconomical. Viscosity can best be reduced by heating the reservoir. The basic aspects of reservoir heating are reviewed in this paper. Conduction-heating processes appear to be the most promising. One such process is the cyclic steam-soak process. A simple method is presented for estimating the performance from the first cycle of steam injection into the formation, assuming gravity as the only driving energy. An example calculation for a typical heavy-oil reservoir is given. The results yield conservative estimates. Fracture-heating processes hold great promise, provided that we can develop means for creating fractures having controlled orientation and direction. Authors' abstract condensed.

Taylor, F. B., 1967, Outlook for shallow oil exploration and development, United States: Am. Assoc. Petroleum Geologists Bull., v. 51, no. 1, p. 134-141. 
More than 120,000 wildcat wells in 14 States were drilled and their records examined during 1950-63. Of these, 22,928 (19 percent) were classified as shallow tests. Of that number 2,274 were discovery wells. Seven successful tests were completed at depths less than 100 feet. From this depth, the number of discoveries increases in virtually a straight-line progression to 2,000 feet, at which depth there were 213 successful completions. Author's text condensed.

Thode, H. G., Monster, Jan, and Dunford, H. B., 1958, Sulphur isotope abundances in petroleum and associated materials: Am. Assoc. Petroleum Geologists Bull., v. 42, no. 11, p. 2619-2641.

A study has been made of sulfur isotope ratios for petroleum from many different oil fields in the United States and Canada. The $\mathrm{S}^{34} / \mathrm{S}^{32}$ ratio for petroleum varies by about 4.5 percent as compared with a total spread of about 9 percent for terrestrial sulfur. Oils from widely separated locations in Alberta, found in the same reservoir rock, have similar sulfur isotope ratios. On the other hand, actual sulfur content of these oils may vary by a factor of 10 . This result indicates that there is little or no fractionation of the sulfur isotopes in the maturation of the oil, during which sulfur is lost. The very high $\mathrm{S}^{34}$ content of the petroleum in the recent sediments of the Uinta Basin in Utah confirms the nonmarine origin of these deposits. The decrease in $\mathrm{S}^{34}$ content with age and depth of petroleum deposit in the basin suggests a gradual $\mathrm{S}^{34}$ enrichment of the sulfate over a period of time in the enclosed lake, probably due to bacterial action. Authors' abstract condensed.

Thurston, R. R., and Knowles, E. C., 1936, Oxygen absorption tests on asphalt constituents: Indus. and Eng. Chemistry, v. 28, no. 1, p. 88-91.

Soft and air-blown Mexican asphalt, gilsonite, and other asphalts were examined, and groups of constituents were separated - asphaltous resins, asphaltenes, petroleum resins, asphaltic resins, and oils. The original asphalts and the constituents of soft Mexican asphalt were subjected to treatment with oxygen in a closed system at $200^{\circ} \mathrm{C}$ and under atmospheric pressures. The volume of oxygen absorbed was measured and the distribution of it in the products of the reaction determined. The solid constituents, the asphaltenes, oxidized most readily, and the oils were more resistant. Authors' abstract.

Thurston, R. R., and Knowles, E. C., 1941, Asphalt and its constituents: Indus. and Eng. Chemistry, v. 33, no. 3, p. 320-324.

Under weathering conditions, asphalt surfaces undergo oxidation. This photo-oxidation property of asphalt and its constituents has been studied by exposing samples in oxygen-filled sealed Pyrex containers under a sunlamp at temperatures approximating $170^{\circ} \mathrm{F}\left(77^{\circ} \mathrm{C}\right)$. The constituents, identified as asphaltenes, resins, naphthalene oil, paraffin oil, and wax, were obtained from three typical petroleum residua. All constituents absorbed oxygen, the resin and naphthalene oil being a little more readily oxidized. Constituent source was also a factor. Part of the used oxygen was eliminated as water and carbon dioxide, and all residues showed weight increase. The method is applicable to paving and roofing asphalts. Authors' abstract.

Traxler, R. N., 1961, Asphalt, its composition, properties and uses: New York, Reinhold Publishing Corp., 294 p. 
This book contains chapters on composition and physical properties of asphalt, but most of it is on asphalt manufacture and uses.

Traxler, R. N., and Schweyer, H. E., 1936, Increase in viscosity of asphalts with time: Am. Soc. Testing and Materials Proc., v. 36, pt. 2, p. 544-550.

When asphalts are maintained undisturbed at $25^{\circ} \mathrm{C}\left(77^{\circ} \mathrm{F}\right)$, the viscosities are found to increase with time. This aging phenomenon has been studied by means of the falling coaxial cylinder viscometer for a number of asphalts of various origins and methods of processing. An asphalt aging index is proposed which quantitatively evaluates the rate of increase in viscosity with time. Development of a thermally unstable structure within the asphalt is probably the cause of the age-hardening phenomenon. Reheating a timehardened sample in-situ returned the asphalt to its original viscosity, provided that not too long a time had elapsed. However, in samples that had aged for several thousand hours, permanent changes were also found to have occurred in the asphalt, and reheating of these samples did not eliminate all the viscosity developed during aging.

U.S. Bureau of Mines, 1967, Heavy crude oil, resource, reserve, and potential production in the United States: U.S. Bur. Mines. Inf. Circ. 8352, 76 p.

This report presents data pertaining to proved reserves, production, and total resources of heavy-crude oil (API gravity of $25^{\circ}$ or less) in the United States. Information is presented for 22 heavy-oil-producing States. This study was confined to subsurface reservoirs containing heavy oils that are mobile at reservoir conditions. Heavy-crude-oil resource on January 1, 1966, was 106.8 billion stb (stock-tank barrels), of which 45.9 billion stb was in reservoirs having characteristics considered to be most favorable for thermalrecovery operations. Estimated recoverable or proved reserve by operating methods, in effect, on this date was 5.2 billion bbl (barrels). Heavy-oil production forecast for the years $1966-80$ is 5,816 million bbl, about 16 percent of which is expected to be recovered from thermal operations.

U.S. Geological Survey, 1951, Bituminous rock and related deposits, in Fuel reserves of the United States: U.S. Congressional Committee on Interior and Insular Affairs, 82d Congress, U.S. Govt. Printing Office, 49 p. [p. 38].

Deposits of asphaltic sandstones, bituminous limestone, and bituminous siltstone constitute a large potential source of liquid fuel, although interest in them in the past has been directed toward their suitability for road surfacing and other construction purposes. Total production of natural asphalt and bituminous rock in the United States has been on the order of 20 million tons containing possibly 1.5 million tons of bitumen, and total production of gilsonite has been about 1.6 million tons. Reserves are listed for the deposits at Vernal and Sunnyside, Utah, Edna, Santa Cruz, and McKittrick, Calif., and Uvalde, Tex. Author's text condensed.

White, David, 1915, Some relations in origin between coal and petroleum: Washington Acad. Sci. Jour., v. 5, p. 189-212.

The effect of progressive regional dynamic alteration is marked by a concentration of hydrogen in the distillates and a concentration of carbon in the 
residual debris (coal, carbonaceous shale, and so forth). Thus, the oil is of light grade where the carbon content of the coal is high, and the oil is heavy where the carbon content is low. If metamorphism has not progressed sufficiently, the carbonaceous material which is the source of the oil and gas will not be sufficiently altered to cause the formation of oil or gas. However, if metamorphism has progressed beyond a certain stage, the oil and gas will, to a large extent, be destroyed, and, according to E. R. Lilley, dry gases composed almost entirely of methane and residual carbon will be formed. Ultimately, if the pressure becomes too severe, the methane is destroyed, and the volatile hydrogen gas is evolved. Because of the small size of the hydrogen molecule, this gas easily escaped from the beds containing it and is lost. Author's text condensed.

Witherspoon, P. A., and Winniford, R. S., 1967, The asphaltic components of petroleum, in Nagy, B., and Colombo, U., eds., Fundamental aspects of petroleum geochemistry: Amsterdam, Netherlands, Elsevier Publishing Co., p. 260-297.

The asphaltic components of petroleum consist of aggregates of a large number of compounds that contain the highest molecular-weight fractions and have the most complicated structure of any of the compounds that make up this fluid. They are in the general classification of nonhydrocarbons because they contain, in addition to hydrogen and carbon, significant amounts of nitrogen, sulfur, and oxygen. These components differ significantly from other constituents of petroleum not only in their chemical composition and structure, but also because of their occurrence as colloidal particles. Because geologically younger crude oils are often more asphaltic than the older oils, some workers have proposed that the transformations of the organic matter involve a youthful stage of heavy asphaltic oils which are further altered by low-temperature physicochemical processes to a mature paraffinic stage. Other workers have proposed that hydrocarbons are transported in aqueous solutions and that the final accumulation is dependent on the solubility characteristics of the various hydrocarbons which make up petroleum. Authors' text condensed.

World Oil, 1964, Thermal recovery projects spur lease play in three-State area: World Oil, v. 159 , no. 1 , p. 103-105.

Following initiation of Shell Co.'s secret hot-water and steam injection work in Vernon County, Mo., in December 1963, more than 20 major and independent companies have leased large blocks of acreage throughout western Missouri, southeastern Kansas, and northeastern Oklahoma. The chief area of interest is underlain by the Bartlesville and Bluejacket Sandstones of Pennsylvanian age. These shallow sands (depth 175-400 feet) contain large amounts of low-gravity, high-viscosity crude which has defied extraction by more conventional secondary-recovery techniques.

Young, R. S., 1954, Preliminary X-ray investigation of solid hydrocarbons: Am. Assoc. Petroleum Geologists Bull., v. 38, no. 9, p. 2017-2020.

Specimens of naturally occurring solid hydrocarbons were subjected to $\mathrm{X}$-ray study in an attempt to determine whether enough inherent structural differences existed to provide a basis for classification. The specimens were asphalt, gilsonite, asphaltum, grahamite, albertite, and several unidentified 
materials. On the basis of X-ray pattern variations, several inferences can be drawn concerning the structure of asphaltites and pyrobitumens. Apparently gilsonite is composed of large "bitumen" molecules arranged in nearly complete disorder. Metamorphism, even in an extremely mild form, has two immediate effects: (1) Partial breakdown of the "bitumen" lamellae into "carbonlike" crystallites and a gaseous product; and (2) a tendency toward a definite and relatively immobile arrangement of the "carbonlike" crystallites. Therefore, with the application of heat and pressure, it is probable that in time a petroleum asphalt will convert to gilsonite, albertite, grahamite, and perhaps even impsonite. Author's text condensed. 



\title{
UNITED STATES
}

\author{
ALABAMA
}

Subject Index

Carboniferous

Ordovician

Ball Associates, Ltd., 1965

Ball, M. W., 1951

Trenton limestone

Ball Associates, Ltd., 1965

Origin

Utterback, D. D., 1954

Resources

Ball, M. W., 1951

Clark, C. H., 1925

Jones, W. B., 1928

Semmes, D. R., 1929

Author List

Ball Associates, Ltd., compiler, 1965, Alabama, in Surface and shallow oilimpregnated rocks and shallow oil fields in the United States: U.S. Bur. Mines Mon. 12, p. 8-18 [p. 10].

The Mississippian limestones and sandstones of northwest Alabama contain a number of asphalt impregnated beds, which extend from northwest to southeast for 70 miles across Colbert, Lawrence, and Morgan Counties. Asphalt impregnates several limestones and sandstones of the Bangor Limestone, the Hartselle Sandstone, the Gasper Limestone (or Oolite) and the Bethel Sandstone. These formations are within the upper 700 feet of the 1,000-foot-thick Mississippian rocks of northwest Alabama. Several deposits have been worked for paving asphalt, although most mining ceased in the 1940's. The Trenton Limestone (Ordovician) is reported to be impregnated with oil in the Coosa Valley (probably in Blount County), and oil seeps and associated oil-impregnated rocks are known in the Knox Dolomite (Ordovician) near Cooks Springs, St. Clair County. Author's text condensed.

Ball, M. W., 1951, Report on oil-impregnated strippable deposits in Alabama as of May 22, 1950, Appendix C, in The synthetic liquid-fuel potential of Alabama: U.S. Army Corps of Engineers, Summary report for the U.S. Bureau of Mines, Department of the Interior: Ford, Bacon \& Davis, Inc., Engineers.

The important deposits in Alabama are scattered throughout an area 70 miles long and 8 miles wide in Morgan, Lawrence, and Colbert Counties. The deposits occur in the Bangor and Gasper limestones and the Bethel and 
Hartselle sandstones in the Mississippian Chester group. The Bangor limestone occurrences are in Morgan County and are mostly tar springs and seeps. Those in the Gasper limestone are in Colbert County near Margerum and Cherokee. The only known deposit in the Bethel sandstone is the bituminous area south of Cherokee, in Colbert County. Hartselle sandstone deposits extend discontinuously from Hartselle in Morgan County through Lawrence and Colbert Counties. The asphaltic sandstone covers a larger area than the asphaltic limestone, but its occurrence is erratic. Reported thicknesses seldom exceed 10 to 12 feet, but range up to 20 feet. Bitumen content also varies within short distances, and ranges from 3 to 9 percent by weight. All the deposits appear to be thin or small or under heavy overburden. Author's text condensed.

Clark, G. H., 1925, Rock asphalts of Alabama and their use in paving: Alabama Geol. Survey Spec. Rept. 13, 96 p., 14 pls.

Asphaltic sandstones crop out in five counties of northern Alabama: Colbert, Lawrence, Morgan, Cullman, and Winston. Asphaltic limestone crops out in Colbert County. The asphaltic deposits occur in Bangor and Gasper limestones and the Bethel and Hartselle sandstones in the Mississippian Chester group. The asphaltic sandstones are sandstones originally containing crude petroleum with which they were more or less saturated. The value of these asphaltic sandstones lies in the fact that the petroleum uniformly coated each individual grain of sand. The resulting asphalt, with its attained viscosity and capacity for compaction, is uniformly distributed through the mass, a condition difficult to duplicate artificially. The geology of the region is not complex. Its sedimentary strata are, for the most part, flat lying and show no changes from heat or pressure. The bitumen content ranges from 1 to 15 percent. Author's text condensed.

Jones, W. B., 1928, Summary of the distribution and occurrence of the rockasphalt deposits of Alabama: Alabama Geol. Survey Circ. 5, 19 p., 7 pls.

Rock-asphalt deposits in Alabama include both sandstones and limestones and are found in the Bangor, Hartselle, Gasper, and Bethel formations. The Hartselle and Bethel are sandstones, whereas the Bangor is a massive, highly fossiliferous limestone, and the Gasper is an oolitic limestone. The occurrence of asphalt in the Bangor probably does not reach commercial proportions, inasmuch as the known areas are scattered and exist merely as springs and seeps. The asphaltic zones in the Hartselle cover a larger area than the others. The thickness ranges from a few inches to 20 feet, and the asphaltic content varies from a trace to an abundance of "frog eyes" of pure asphalt standing out all over the exposed surface. Commercial deposits of rock asphalt in the Gasper are confined to Colbert County and extend from Cherokee westward to the State line. The thickest outcrop observed by the author was 20 feet thick, 4 miles south of Margerum. The outcrop area of the Bethel is approximately the same as that of the Gasper, although the Bethel extends much farther eastward. In general, the asphaltic content of the Bethel is somewhat higher than that of the Gasper, owing to the sandstone's greater porosity. Author's text condensed.

Semmes, D. R., 1929, Oil and gas in Alabama: Alabama Geol. Survey Spec. Rept. 15, 408 p., 76 figs., 13 maps [p. 64-67, 73, 126, 161 ]. 
In Colbert County, rather extensive asphaltic impregnations occur in the Hartselle sandstone in the vicinity of Littleville and Cherokee and in the Gasper limestone near Margerum. In 1924 two deposits were being mined. The asphalt content ranged from 4.6 to 10.6 percent. At several localities in Lawrence County, the Hartselle sandstone shows extensive asphaltic impregnation ranging from 3 to 10 percent. Asphaltic impregnations and tar springs occur in the Bangor limestone near Copsey Creek. In Morgan County in the Hartselle sandstone, tar springs, asphalt, and maltha showings are abundant. The Hartselle sandstone has asphaltic showings near the town of Hartselle and is impregnated with asphalt in the vicinity of Flint. The upper crinoidal limestones of the Bangor also contain asphalt in Morgan County.

Utterback, D. D., 1954, New questions on origin of oil: Oil and Gas Jour., v. 53, no. 16 , p. 121-124.

The author investigated surface outcrops of limestones and sandstones containing asphalt or heavy oil. The purpose of this work was to develop positive information on the nature of these occurrences that would add to knowledge of their origin. Four conclusions were reached by the author regarding the origin of the deposits in the Gasper limestone in Colbert County, Alabama. (1) The asphalt in the Gasper limestone is contained in and around oolites, but is absent in the matrix and in cavities in large fossil fragments. (2) The occurrence is not a residual oil pool. (3) Because of the absence of openings in and around asphaltic material, the asphalt probably was originally deposited as a viscous mass having about the same density as at present. (4) It is unlikely that the asphalt was formed by oxidation of oil carried downstream from an eroded oil pool. Author's text condensed.

\section{ALASKA}

Subject Index

Areal geology

Chignik Lagoon area

Ball Associates, Ltd., 1965

Keller, A. S., and Case, J. T., 1956

Iniskin-Chinitna Peninsula

Moffit, F. H., 1927

Kamishak Bay region

Mather, K. F., 1925

Okpikruak and Kiruktogiak Rivers area

Patton, W. W., Jr., and Tailleur, I. L., 1950

Upper Siksikpuk-Nanushuk Rivers area

Patton, W. W., Jr., and Keller, A. S., 1950

Utukok-Corwin region

Chapman, R. M., and Sable, E. G., 1960

\section{Cretaceous}

Point Barrow region

Jurassic

Paige, Sidney, Foran, W. T., and Gilluly, James, 1925

Point Barrow region

Paige, Sidney, Foran, W. T., and Gilluly, James, 1925 


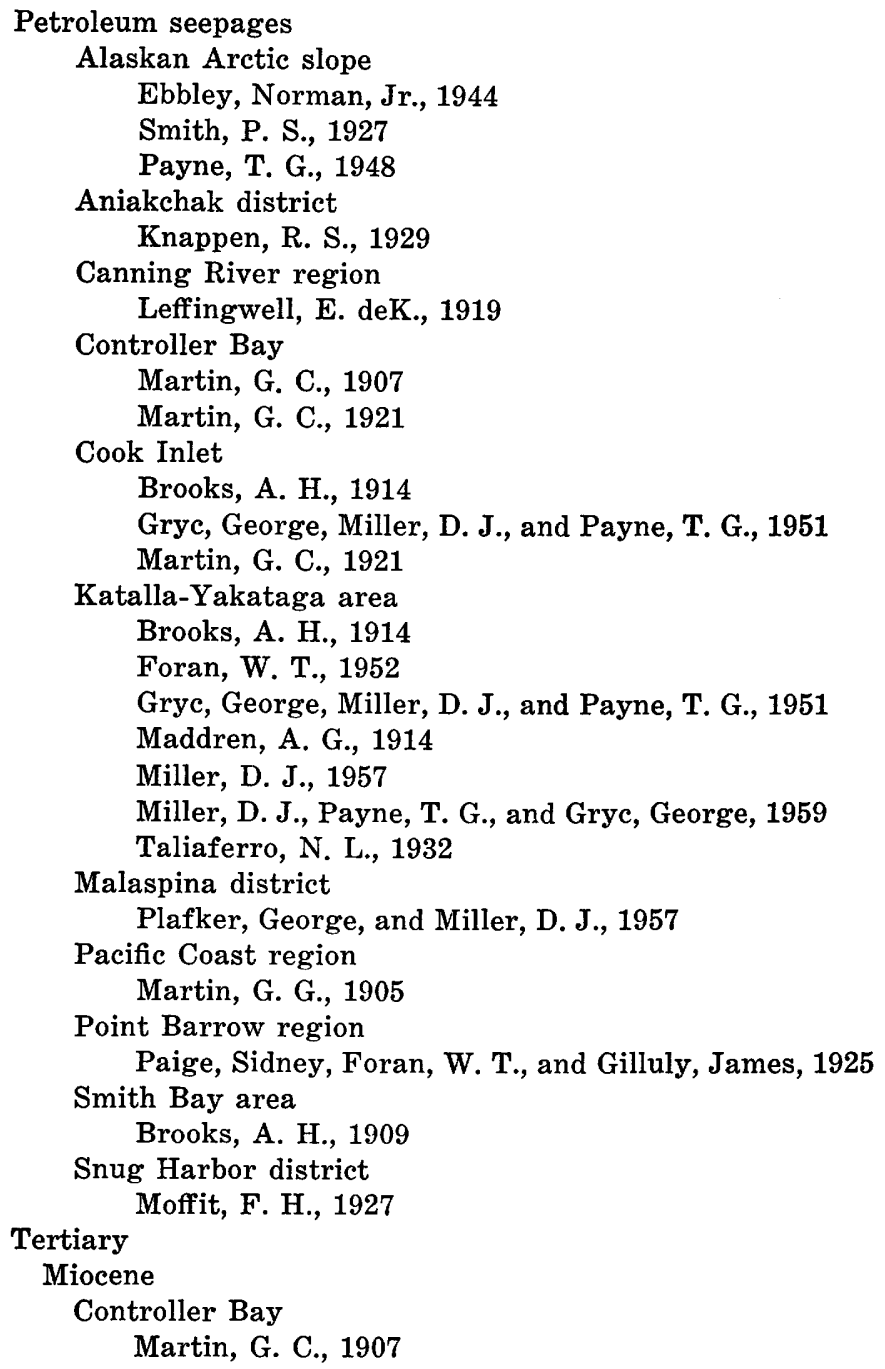

\section{Author List}

Ball Associates, Ltd., compiler, 1965, Alaska in Surface and shallow oilimpregnated rocks and shallow oil fields in the United States: U.S. Bur. Mines Mon. 12, p. 18-41 [p. 20].

Petroleum-impregnated rocks crop out throughout Alaska: In the Arctic Foothills province, north of the Brooks Range; along the southern and western coastal areas; and along the central Alaska-Yukon border. Cretaceous and Tertiary sandstones and Mississippian and Triassic limestones are host rocks. The most significant accumulation is in the Chignik Lagoon area, on the east side of the Alaska Peninsula. Author's text condensed. 
Brooks, A. H., 1909, The mining industry in 1908: U.S. Geol. Survey Bull. 379-A, p. 21-62 [p. 61].

Petroleum residue occurs near Smith Bay, east of Point Barrow. The material occurs in a mound that is several hundred yards in diameter and stands about 150 feet above the level of the tundra. The material resembles asphalt, but contains considerable vegetable matter and silt. It apparently is the residue from petroleum which had impregnated peat and from which the volatile constituent had evaporated. This material resembles that described by G. C. Martin from Cold Bay, Alaska Peninsula, which was formed by the soaking of a peat bog by petroleum seepage. At Cold Bay, however, the petroleum has a paraffin base, whereas at Smith Bay it has an asphalt base. So far as is known, the region near Smith Bay is underlain by Tertiary beds. Author's text condensed.

Brooks, A. H., 1914, The mineral deposits of Alaska: U.S. Geol. Survey Bull. 592-A, p. 18-44 [p. 40].

Petroleum seepages occur (1) near Katalla on the Pacific Coast, and (2) near Yakataga, 60 miles to the east. At Katalla there has been small production from two or three wells. The surface rocks of the Katalla field are closely folded and faulted Tertiary shales and sandstones. Nothing is known as to the source of the oil. Petroleum seepages also occur on the west side of Cook Inlet near Iniskin Bay, where the rocks, Jurassic in age, are chiefly shales and sandstones. These lie in broad open folds, a condition favorable to petroleum accumulation, but are broken by faults. Similar conditions prevail at Cold Bay, 160 miles to the southwest, where petroleum seepages also occur. Some petroleum residue has been found near the south end of Smith Bay, an indentation on the Arctic Coast of Alaska, east of Point Barrow. Author's text condensed.

Chapman, R. M., and Sable, E. G., 1960, Geology of the Utukok-Corwin region, northwestern Alaska: U.S. Geol. Survey Prof. Paper 303-C, p. 47-167 [p. 154] [1961].

Three sandstone beds near the Utukok River in the Carbon Creek anticline contain petroleum residues. A sample collected from a petroliferous sandstone bed at about 3.65 miles southeast of Omicron Hill yielded a very pale strawcolored cut and a pale-yellow residue when treated with $\mathrm{CCl}_{4}$. A sample from a petroliferous sandstone bed on a sharp north bend of the Utukok River about 6 miles west of Carbon Creek, when treated with $\mathrm{CCl}_{4}$ yielded a very pale straw-colored cut and a pale-yellow residue. A sample from a sandstone bed on Omicron Hill in the lowest part of the Kukpowruk formation yielded a black cut and a brownish-black residue when treated with $\mathrm{CCl}_{4}$. A small fault cuts this bed, and for a distance of 100 feet on each side of this fault, the sandstone is moderately dark brownish gray. Beyond these limits, the dark color is absent. All three samples are of low permeability. One 7-foot silty sandstone bed in the Corwin formation, exposed along the Kakolik River just north of the Oilsand syncline axial zone, has a high asphaltic content. Stratigraphically, the oil sand lies in a coaly sequence of the Corwin about 2,400 feet above the base. Authors' text condensed.

Ebbley, Norman, Jr., 1944, Oil seepages on the Alaskan Arctic slope: Mining and Metallurgy, v. 25, no. 453, p. 415-419. 
Petroleum seepages occur over a wide area in northern Alaska, but little is known of the oils or of their mode of occurrence and distribution. Only about one-third of the area where seepages are found has been covered by geological reconnaissance surveys. The seven following Arctic slope petroleum seepages were visited and are described in this report: The Umiat Mountain area, the Fish River Seep, the Dease Inlet Seep, Cape Simpson area, Barter Island area, Un-goon Point area, and White Mountain area. Locations of these seepages are shown on an accompanying map.

Foran, W. T., 1952, Southeastern Alaska's Katalla-Yakataga oil province: Oil and Gas Jour., v. 50, no. 49, p. 166, 168, 171 [p. 124-126].

Seepages of the Katalla-Yakataga areas seem to be the result of slightly fractured pools that have related fault vents to the surface. This occurrence strongly suggests localized accumulations in the subadjacent areas. Source material for this area may be oil residue occurring in seepages and in fractures of the underlying Mesozoic formation. Porosity, sand, and shale conditions are well suited to the migration and pooling of oil. Analysis of the residue and seepage oil at Katalla and Yakataga shows extremely low sulfur content and suggests that it is comparable to the Salt Creek, Wyo., oil. Author's text condensed.

Gryc, George, Miller, D. J., and Payne, T. G., 1951, Alaska, in Ball, M. W., ed., Possible future petroleum provinces of North America: Am. Assoc. Petroleum Geologists Bull., v. 35, no. 2, p. 151-168.

Alaska's small production of petroleum, aggregating about 154,000 barrels, was obtained between 1902 and 1933 from 60 acres near Katalla on the south coast. Production ceased when the small refinery burned in December 1933. In several large areas oil seepages, gas, and residues have been known for years. These are Northern Alaska, Katalla-Yakataga, Cook Inlet-Alaskan Peninsula, Bristol Bay, Interior Alaska, and the Continental Shelf. Authors' text condensed.

Keller, A. S., and Cass, J. T., 1956, Petroliferous sand of the Chignik formation at Chignik Lagoon, Alaska: U.S. Geol. Survey open-file report, 5 p., 2 figs.

The petroleum-bearing sand is exposed along the northwest side of Chignik Lagoon. The rocks in this area are sandstone, siltstone, shale, and conglomerate of the Chignik and Naknek formations. This report describes the stratigraphic section in which the sands are found, gives the results of porosity and permeability tests, and lists the fossils found in the sands.

Knappen, R. S., 1929, Geology and mineral resources of the Aniakchak district: U.S. Geol. Survey Bull. 797-F, p. 161-223 [p. 210$]$.

North of the Aniakchak district in the vicinity of Portage and Cold Bays, oil seepages are known in the Shelikof formation (Upper Jurassic). This formation probably underlies certain folds northwest of Portage Bay, which were drilled for oil. The possible petroliferous formations in the Aniakchak district perhaps lie in or below the Shelikof formation. Author's text condensed. 
Leffingwell, E. deK., 1919, The Canning River region, northern Alaska: U.S. Geol. Survey Prof. Paper 109, 251 p. [p. 178].

At Cape Simpson on the west side of Smith Bay, there are two conspicuous mounds. Petroleum residue is reported from one of them. The deposit is near the shore, and the natives say that a considerable amount could easily be dug out with spades. Natives also report another petroleum mound between Humphry Point and Aichillik River, near the coast. According to current reports an oil seepage has been discovered in northern Alaska near Wainwright Inlet, about 100 miles southwest of Point Barrow. If this report is confirmed, it may indicate an oil field between Wainwright Inlet and Smith Bay. Author's text condensed.

Maddren, A. G., 1914, Mineral deposits of the Yakataga district: U.S. Geol. Survey Bull. 592-E, p. 119-153.

The best-known petroleum seepages of the Yakataga district are located near the base of the seaward slopes of the coastal ridge of Robinson Mountains. These seepages are distributed along a line extending from a point near Yakataga Reef to Johnston Creek, a distance of about 18 miles. They are 1/2-2 miles from the beach. About a dozen seepages are distributed at irregular intervals along this line. The extreme easternmost seepage, on Johnston Creek about $1 \frac{1}{2}$ miles above its mouth, is the only one of considerable volume. Most of these seepages are little more than meager indications of oil in the form of sulfurous coatings or exudations along joints. Thick oily residue has accumulated in notable quantity only at the seepage on Johnston Creek. Author's text condensed.

Martin, G. C., 1905, The petroleum fields of the Pacific Coast of Alaska, with an account of the Bering River coal deposits: U.S. Geol. Survey Bull. $250,64 \mathrm{p}$.

Petroleum seepages are very abundant in the Controller Bay region. Those best known are about 4 miles east of Katalla. The flow of oil has caused large pools to form on the surface. Another group of seepages is on the headwaters of Burls Creek, where the petroleum may be seen oozing from joints and bedding planes of the carbonaceous shales and volcanic ash beds exposed in the deep ravines. Cold Bay is located on the south shore of the Alaska Peninsula, opposite the west end of Kodiak Island. Seepages of petroleum occur about 5 miles inland from Cold Bay. The petroleum runs down the hillsides in the watercourses, collecting at the bottom in peat bogs. Having lost enough of its volatile constituents by evaporation to render it immobile, it remains there, impregnating the peat and forming a thick coating of black paraffin wax over the surface. The deposit has an area of about $1 \frac{1}{2}$ acres. The material has been dug to a depth of 3 feet, sometimes without reaching bottom. Another deposit discovered in this vicinity covers an area of 3 acres and is at least 10 feet thick. Author's text condensed.

Martin, G. C., 1907, Petroleum at Controller Bay: U.S. Geol. Survey Bull. 314-E, p. 89-103 [p. 92-93].

Oil seepages occur within a long, narrow belt, about 4 miles wide, extending from the edge of the Copper River delta to Bering Glacier, a distance 
of about 28 miles from east to west. The seepages west of Katalla are associated with metamorphic rocks, the oil reaching the surface either through joints and bedding or through cleavage planes of the slate and graywacke or through surficial deposits which probably overlie such rocks. The author suggests that the metamorphic rocks, which are known to be separated from the Tertiary shales by a fault, are overthrust upon the shales along a fault plane of low hade, and that the oil of the seepages is coming through the metamorphic rocks from underlying shales. The seepages at the head of Katalla Slough and on Redwood, Burls, and Chilkat Creeks are all in the soft shales that have been called the Katalla formation. Those between Redwood and Burls Creeks are associated with conglomerates, presumably higher in the section. The Cape Yakataga seepages are said to be in Miocene sandstones and shales. Author's text condensed.

Martin, G. C., 1921, Preliminary report on petroleum in Alaska: U.S. Geol. Survey Bull. 719, 83 p. [p. 9-75].

Indications of petroleum have been found in five districts in Alaska. Four are on the Pacific Coast - the Katalla or Controller Bay field, the Yakataga district, the Iniskin Bay district on Cook Inlet, and the Cold Bay district on the Alaskan Peninsula. The fifth, which includes areas near Smith Bay, is on the Arctic Coast. The petroleum on the Pacific Coast of Alaska, as it is known from wells near Katalla and from seepages in the Yakataga, Iniskin, and Cold Bay districts, is a high-grade refining oil with a paraffin base. The petroleum found near Smith Bay appears to have an asphaltic base. Some of the seepages of petroleum on the hillsides near Cold Bay are continuous; others are intermittent. The petroleum runs down the hillsides into the watercourses and collects at the bottom of peat bogs. Losing enough of its volatile constituents by evaporation to become immobile, it remains there, impregnating the peat and forming a thick coating of a black paraffin wax over its surface. Author's text condensed.

Mather, K. F., 1925, Petroleum on Alaska Peninsula - Mineral resources of the Kamishak Bay region: U.S. Geol. Survey Bull. 773-D, p. 159-181 [p. 176-177].

During fieldwork on which this report is based, no seepages of oil were observed in the Kamishak Bay region, but reliable reports indicate an oil seepage near Bruin Bay within the mapped area. According to these reports, there is a small oil seepage about 50 yards off the point on the south side of the entrance to Bruin Bay. Bubbles of gas come from the clean sand and, breaking at the water surface, spread a film of oil over a considerable area. The odor of gas and oil is very distinct. The locality is approximately on the crest of the Chenik anticline, if that anticline extends northeastward from the locality at which it disappears beneath the water of Kamishak Bay. Author's text condensed.

Miller, D. J., 1957, Geology of the southeastern part of the Robinson Mountains, Yakataga district, Alaska: U.S. Geol. Survey Oil and Gas Inv. Map OM-187.

All the known oil and gas seeps in this region are in the southeastern part of the Robinson Mountains and are shown on this map. The seeps are near the coast, in a narrow belt extending along the axis of the Sullivan anticline 
from Johnston Creek to a point near the west end of Brower Ridge. One oil seep is present on the north side of the Yakataga River Valley, between the Yakataga River and Porcupine Creek. Beds of sandstone or siltstone having a petroliferous odor, some yielding a small amount of oil when treated with $\mathrm{CCl}_{4}$, were found in outerops of the Yakataga formation near the mouth of Kulthieth River in the western part of the Robinson Mountains. At one locality on the north branch of the White River, near the axis of the White River syncline, oil is entrapped in calcite veinlets that fill fractures in sandstone of the Yakataga formation. About 75 percent of the known oil seeps and all the large gas seeps occur on outcrops of the Poul Creek formation. The remaining oil seeps and other indications of petroleum are associated with the Yakataga formation. In the Samovar Hills area of the Malaspina district, however, large oil seeps have been found in outcrops of coal-bearing strata with the Kulthieth formation. Author's text condensed.

Miller, D. J., Payne, T. G., and Gryc, George, 1959, Geology of possible petroleum provinces in Alaska, with an annotated bibliography, by E. H. Cobb: U.S. Geol. Survey Bull. 1094, 131 p. (Supersedes Map I-84.)

In the Katalla district the known oil seeps and the indications of oil in wells are confined to a narrow eastward-trending belt near the coast. Investigations have shown that most of the oil seeps are in the outcrop area of the middle part of the Katalla formation, which locally includes a petroliferous, highly organic shale. In the western part of the Katalla district, oil seeps from hard siltstone and sandstone of probable early Tertiary age and, also, from pre-Tertiary metamorphic rocks near the contact with the lower Tertiary (?) strata. In the Yakataga district, the known oil seeps occur in the outcrop area of the Poul Creek formation and the lower part of the Yakataga formation. Nearly all the oil seeps are on or near the faulted crest of the Sullivan anticline, which lies near the coast. Authors' text condensed.

Moffit, F. H., 1927, The Iniskin-Chinitna Peninsula and the Snug Harbor district, Alaska: U.S. Geol. Survey Bull. 789, 71 p. [p. 52].

In the Iniskin-Chinitna Peninsula, the oil seepages and drill holes showing oil are within the area of the Tuxedni sandstone (Middle Jurassic). So far as is known, none of the seepages - except the gas spring at Dry Bay - are within areas of the Chinitna shale or the Naknek formation (Upper Jurassic). The source of the oil is therefore believed to be within the Tuxedni sandstone or possibly at some lower horizon. Two of the drill holes at Oil Bay are reported to have penetrated oil-bearing sands at depths of 500-700 feet and to have shown a considerable quantity of oil. Author's text condensed.

Paige, Sidney, Foran, W. T., and Gilluly, James, 1925, A reconnaissance of the Point Barrow region, Alaska: U.S. Geol. Survey Bull. 772, 33 p. [p. 23].

The Cape Simpson oil seepages consist of two occurrences on the margin of the Arctic Ocean. A low moss-covered ridge stretches for 2 miles along the Arctic Ocean, its southeast terminal about 1 mile northwest of Cape Simpson. Its highest point is about 50 feet above the sea. Seepage No. 1 occurs near the island base of this ridge, one-third of a mile from the ocean and 20 feet above tidewater, from which it is visible. In an irregular area several hundred feet in diameter, the mass is soaked with petroleum which slowly seeps from the 
gentle slope. Seepage No. 2 is on top of a small double knob 40 feet high, 3 miles south of seepage No. 1 and 11/4 miles west of Smith Bay. The residue from the seepage covers several acres. The main petroleum flow moves southward down the slope 600 to 700 feet to a lake. This active channel is 6 to 10 feet wide, though the area covered by residue is several hundred square feet and indicates that a considerable flow comes from this seepage. The rocks from which petroleum seeps are believed to be Upper Jurassic or Lower Cretaceous. Authors' text condensed.

Patton, W. W., Jr., and Keller, A. S., 1950, Preliminary report on the stratigraphy and structure of the Upper Siksikpuk-Nanushuk Rivers area, Alaska: U.S. Geol. Survey open-file report, Geological Investigations Naval Petroleum Reserve No. 4, 20 p., 6 pls., 3 figs.

Asphaltic material is common in seams and fractures in the Kingak, Okpikruak (Jurassic-Cretaceous), and Torok (Cretaceous) formations. Soft gummy asphaltic matter that burns readily commonly occurs interbedded with chert in the Kingak formation. Some of the paper shales of the Shublik (Triassic) formation give off a strong petroliferous odor when heated. Authors' text condensed.

Patton, W. W., Jr., and Tailleur, I. L., 1950, Stratigraphy and structure of the Okpikruak and Kiruktagiak Rivers area, Alaska: U.S. Geol. Survey open-file report, Geological Investigations Naval Petroleum Reserve No. 4, 15 p., 3 pls.

Much of the dark limestone in the Kiruktagiak member of the Lisburne (Mississippian) limestone has what is described as an "oil shale" odor. Oil shales are present in the lower cherty section of the Shublik (Triassic) formation. A 15-foot zone on Monotis Creek is the thickest section exposed. Asphaltic material generally associated with vein calcite commonly occurs as fracture fillings in the Torok (Cretaceous) formation. On Fortress Mountain, a Torok conglomerate bed consists of angular chert granules cemented by asphaltic material. Authors' text condensed.

Payne, T. G., 1948, A real evaluation of petroleum possibilities of major stratigraphic units in northern Alaska: U.S. Geol. Survey open-file report, Geological Investigations Naval Petroleum Reserve No. 4, 17 p., 10 figs.

The late Tertiary-Quaternary sediments constitute the surface formation at most of the oil seepages in the coastal belt; the oil probably is indigenous to the underlying lower Tertiary rocks. Where the surface formation is composed largely of clay, as at the Cape Simpson seepages, it may act as an impervious cap to gently dipping lower Tertiary oil sands that may terminate unconformably beneath it. The occurrence of oil seepages in the coastal belt may be determined by the presence, in the capping formation, of open fractures in the permafrost, as well as by termination, beneath the surface formation, of lower Tertiary oil sands. Author's text condensed.

Plafker, George, and Miller, D. J., 1957, Reconnaissance geology of the Malaspina district, Alaska: U.S. Geol. Survey Oil and Gas Inv. Map OM-189, with text.

During the investigation of the Malaspina district, large oil seeps were 
found in the Samovar Hills. These seeps issue from fracture zones in the Yakutat group and from sandstone beds and fault zones in the lower unit on Hubbs Creek. The oil has an API gravity of 29.5 and a sulfur content of 1.13 percent. No likely source beds for the oil in these seeps are exposed in the Samovar Hills. However, argillaceous strata of the lower Tertiary (?) siltstone sequence may underlie the Kulthieth formation west of Hubbs Creek. Authors' text condensed.

Smith, P. S., 1927, Geologic investigations in northern Alaska: U.S. Geol. Survey Bull. 792-C, p. 111-120.

Petroleum is found seeping from the ground near Cape Simpson on the Arctic Coast. The possible oil-bearing rocks are of Mesozoic age and occur entirely north of the Brooks Range. Author's text condensed.

Taliaferro, N. L., 1932, Geology of the Yakataga, Katalla, and Nichawak districts, Alaska: Geol. Soc. America Bull., v. 43, no. 3, p. 749-782, 14 figs.

The Poul Creek shales occur along the crest of the Yakataga anticline and very probably on the crest of the next anticline to the north, where lithologically identical beds were observed on the western side of Yakataga Glacier. Their total thickness is not known, but is at least 3,000 feet. Eastward from Two Mile Creek, these beds form a continuous belt, 17 miles long with a maximum width of more than 1 mile, for as far as Big River, where they disappear beneath alluvium and glacial outwash. All the well-known oil and gas seepages of the Yakataga district come from these shales along the tightly folded and crushed crest of Yakataga anticline. Author's text condensed.

\section{ARIZONA}

Subject Index

Oil seeps

Structure

Ball Associates, Ltd., 1965

Holm, D. A., 1947

Butler, G. M., and Tenney, J. B., 1931

\section{Author List}

Ball Associates, Ltd., compiler, 1965, Arizona, in Surface and shallow oilimpregnated rocks and shallow oil fields in the United States: U.S. Bur. Mines Mon. 12, p. 41-47 [p. 41].

Petroleum-impregnated rocks are few and widely scattered in Arizona; none are of commercial importance as of 1964.

Butler, G. M., and Tenney, J. B., 1931, Petroleum: Arizona Bur. Mines Bull. 130, Oil Ser. 5 (Arizona Univ. Bull., v. 2, no. 1), 50 p., 10 figs.

On the western edge of the Plateau region are a series of north-trending faults with minor domes and basins developed between them. In one of these minor folds in the southwestern corner of Utah, near Virgin City, shallow oil has been found in small quantities in lower Triassic beds. The structure is reported to extend into Arizona between the Hurricane and Grand Wash 
faults, south of the village of Hurricane, Utah. Drilling had been done on these structures, and only a trace of oil or gas was found in 1931. Authors' text condensed.

Holm, D. A., 1947, Report on the oil possibilities of Arizona: Arizona State Land Dept. Rept., 59 p. [p. 42-46, 51-55].

Seepages in wells were observed in parts of southern Arizona, particularly in the Salt River Valley and the Willcox district. These seepages are listed in the appendix of this report.

\section{ARKANSAS}

Subject Index

Analyses

Hayes, C. W., 1903

Taff, J. A., 1909

Carboniferous

Ball Associates, Ltd., 1965

Reinemund, J. A., and Danilchik, Walter, 1957

Cretaceous

Ball Associates, Ltd., 1965

Hayes, C. W., 1903

Miser, H. D., and Purdue, A. H., 1919

Miser, H. D., and Purdue, A. H., 1929

Exploration

Spooner, W. C., 1935

Johnson, C. H., Picklesimer, H. G., and Hoagland, A. D., 1940

Oil seeps

Batesville sandstone

Croneis, C. G., 1930

Johnson, C. H., Picklesimer, H. G., and Hoagland, A. D., 1940

Vein deposits

Fourche Mountain

Taff, J. A., 1909

\section{Author List}

Ball Associates, Ltd., compiler, 1965, Arkansas, in Surface and shallow oilimpregnated rocks and shallow oil fields in the United States: U.S. Bur. Mines Mon. 12, p. 47-57 [p. 47].

Eight areas of Carboniferous accumulations in Washington, Madison, Newton, and Independence Counties, Ark., include the rare septarian concretions containing oil at Kingston and Yardelle, a Mississippian seep at Batesville Dam, and scattered oil-soaked sandstone outcrops of Pennsylvanian age. Many of the Ozark Plateau Paleozoic rocks, when broken, exude the fetid smell of petroleum. The Wedington sandstone (Mississippian) outcrops are typically bituminous. The Fourche Mountain accumulation in southwest Arkansas is the only one of solid (though small) bituminous masses, filling relatively large secondary openings in the host rock, not merely impregnating its primary pores. The southwest accumulations, except Fourche Mountain, are impregnations of the Lower Cretaceous Trinity Formation sandstones. Two, at Pike and Delight, may have commercial possibilities. Author's summary condensed. 
Croneis, C. G., 1930, Geology of the Arkansas Paleozoic area, with special reference to oil and gas possibilities: Arkansas Geol. Survey Bull. 3, 457 p. [p. 356-357].

Most of the surface indications of oil in the Paleozoic area of Arkansas are found north of the Arkansas River. A number of Paleozoic rocks of the Ozark plateaus give off the odor of petroleum when freshly fractured, but most of the true seeps are in the post-Boone formations. The Batesville sandstone is at several places somewhat impregnated with bitumen, and oil is reported to be seeping from that sandstone at the base of the Upper Batesville dam, near Batesville. All surface indications of oil described in this report are in the southern part of the Springfield plateau and in the Boston Mountains. Author's text condensed.

Hayes, C. W., 1903, Asphalt deposits of Pike County, Arkansas: U.S. Geol. Survey Bull. 213-H, p. 353-355.

At many places in Pike County, the Trinity sandstones (Cretaceous) contain bituminous matter, usually in the form of asphalt. The most extensive deposits occur about 21/2 miles southeast of Pike City on a branch of Wolf Creek. The sandstone varies in thickness from 6 to 12 feet and is saturated with asphalt. Specimens taken from this deposit vary in bitumen content from 5.06 to 16.53 percent.

Johnson, C. H., Picklesimer, H. G., and Hoagland, A. D., 1940, Mineral resources of Benton, Carroll, Madison, and Washington Counties, Arkansas: Arkansas Geol. Survey County Mineral Rept. 2, 55 p. [p. 46].

Surface structures, oil seeps, and shows of oil in water wells in northwest Arkansas have led to exploration and wildcatting for oil and gas. Several test wells have had indications of oil and gas. Locations of oil seeps and test wells are tabulated. The formations or members of formations considered to be the most favorable for oil or gas accumulation are the Sylamore sandstone, the Hale sandstone, the Wedington sandstone, the St. Peter sandstone, the Kings River sandstone, the Everton sandstone, and the Boone limestone. Authors' text condensed.

Miser, H. D., and Purdue, A. H., 1919, Asphalt deposits and oil conditions in southwestern Arkansas: U.S. Geol. Survey Bull. 691-J (Pt. 2, Mineral fuels), p. 271-292.

Seven asphalt deposits - three in Pike County and four in Sevier County in southwestern Arkansas - were examined by the writers. The deposits have a general east-west alinement on the north border of the Gulf Coastal Plain, north of which is the Ouachita Mountain region. The asphalt impregnates nearly horizontal beds of loose sand in the basal part of the Dierks limestone lentil or still lower in the Trinity formation. The layers containing the asphalt range in thickness from 1 inch to 12 feet. The Carboniferous and older rocks have been so highly tilted, fractured, and metamorphosed that if oil or gas were ever present in them, it would have escaped to the surface, and the remainder of the oil would have been distilled to asphalt. Authors' text condensed.

Miser, H. D., and Purdue, A. H., 1929, Geology of the DeQueen and Caddo Gap quadrangles, Arkansas: U.S. Geol. Survey Bull. 808, 195 p. [p. 157161]. 
The asphalt impregnates nearly horizontal beds of loose sand in the basal part of the Dierks lentil or still lower in the Trinity formation. The deposits thus consist of asphaltic sand, except at one place where the asphalt impregnates the Pike gravel member at the base of the formation. The layers containing the asphalt range in thickness from 1 inch to 12 feet. The Trinity formation contains petroleum and asphalt at many places in northern Texas and southeastern Oklahoma. It is doubtless a residue of crude petroleum, whose lighter and more volatile parts have escaped by evaporation. The petroleum yielding the asphalt in Arkansas may have originated in the basal part of the Trinity formation, which contains some fossiliferous limestone. Authors' text condensed.

Reinemund, J. A., and Danilchik, Walter, 1957, Preliminary geologic map of the Waldron quadrangle and adjacent areas, Scott County, Arkansas: U.S. Geol. Survey Oil and Gas Inv. Map OM-192, with geologic sections and text.

A deposit of solid bitumen is present in the Jackfork (Pennsylvanian) sandstone near Eagle Gap in southern Scott County, Ark. The bitumen was probably formed by the devolatilization of crude oil migrating along faults from older rocks. Its presence does not contribute any data on the possibilities of oil accumulation in the rocks exposed in the Waldron quadrangle. Authors' text condensed.

Spooner, W. C., 1935, Oil and gas geology of the Gulf coastal plain in Arkansas: Arkansas Geol. Survey Bull. 2, 474 p. [p. 426, 447], 22 pls. incl. geol. maps, 95 figs. incl. maps, 57 tables [not a State rept.], Little Rock, Ark., privately printed by Parke-Harper Printing Co.

In Sevier and Pike Counties, deposits of asphalt-impregnated sand occur in the basal part of the Dierks lentil and in the sand beneath, and in at least one locality, the Pike gravel member contains asphalt. The asphalt-impregnated beds range in thickness from 1 inch to 12 feet. Author's text condensed.

Taff, J. A., 1909, Fourche Mountain, Arkansas, locality, in Grahamite deposits of southeastern Oklahoma: U.S. Geol. Survey Bull. 380-H, p. 286-297.

Deposits of solid bitumen occur at the west end of Fourche Mountain, in Arkansas, about 12 miles east of the Black Fork Mountain, Okla. locality. The deposits occur in a shear zone of shale and sandstone and are in the form of veinlets separated by crushed and slickensided shales. The bitumen product itself shows the effects of crushing forces, being sheared and slickensided. It resembles the solid bitumen of Black Fork Mountain, except that it is probably more friable and more highly metamorphosed than the Black Fork Mountain product. The Fourche Mountain deposit contains 17.78 percent volatile bitumen, as compared with 23.06 percent for Black Fork Mountain and 43.33 for Impson Valley grahamite. Author's text condensed.

\section{CALIFORNIA}

Subject Index

Analyses

Carman, E. P., and Bayes, F. S., 1961

Emery, K. O., 1960 
Analyses - Continued

Hail, W. J., Jr., 1957

Hilgard, E. W., 1885

Kramer, A. J., and Smith, H. M., 1924

Poth, E. J., and others, 1930

Asphalt deposits

Casmalia

Adams, E. W., and Beatty, W. B., 1962

Gore, F. D., 1924

Jennings, C. W., 1957

Oakeshott, G. B., 1950

Williams, M. D., and Holmes, C. N., 1945

Coalinga

Arnold, Ralph, and Anderson, Robert, 1910

Watts, W. L., 1900

Cuyama Valley

English, W. A., 1916

Edna

Adams, E. W., and Beatty, W. B., 1962

Bradley, W. W., Huguenin, C. A., Logan, C. A., and Waring, C. A., 1917

Carman, E. P., and Bayes, F. S., 1961

Crawford, J. J., 1896

Eldridge, G. H., 1901

Fairbanks, H. W., 1900

Fairbanks, H. W., 1904

Hail, W. J., Jr., 1957

Jennings, C. W., 1957

Krueger, M. L., 1943

Oakeshott, G. B., 1950

Page, B. M., and others, 1944

Shea, G. B., and Higgins, R. V., 1948

McKittrick

Adams, E. W., and Beatty, W. B., 1962

Church, C. C., 1968

Crawford, J. J., 1896

Eldridge, G. H., 1901

English, W. A., 1921

Jennings, C. W., 1957

Merriam, J. C., and Stock, Chester, 1921

Merriam, J. C., and Stock, Chester, 1925

Oakeshott, G. B., 1950

Pack, R. W., 1920

Page, B. M., 1945

Poth and others, 1930

Stevens, J. B., 1943

VanderHoof, V. L., 1935

Watts, W. L., 1900

Offshore deposits

Emery, K. O., 1960

Vernon, J. W., and Slater, R. A., 1963

Wilson, T. A., and Mero, J. L., 1966 
Asphalt deposits - Continued

Point Arena

Holmes, C. N., Page, B. M., and Duncan, D. C., 1951

Weber, A. H., 1887

Rancho La Brea

Jennings, C. W., 1947

Oakeshott, G. B., 1950

Stock, Chester, 1930

Watts, W. L., 1896

Regional

Ball Associates, Ltd., 1965

Ball, M. W., 1951

Carlson, C. R., 1962

Carman, E. P., and Bayes, F. S., 1961

Crawford, J. J., 1896

Dietzman, W. D., Carrales, M., Jr., and Jirik, C. J., 1965

Eldridge, G. H., 1901

Heizer, R. F., 1943

Hilgard, E. W., 1885

Hoots, H. W., 1943

Jennings, C. W., 1957

Oakeshott, G. B., 1950

Orcutt, W. W., 1925

Peckham, S. F., 1882

Smith, M. B., 1966

Taff, J. A., 1908

Vander Leck, Lawrence, 1922

Watts, W. L., 1894

Salt Lake

Arnold, Ralph, 1905

Eaton, J. E., 1926

Salinas Valley and vicinity

Bramlette, M. N., and Daviess, S. N., 1945

English, W. A., 1919

Pack, R. W., and English, W. A., 1915

Santa Cruz

Branner, J. C., Newsom, J. F., and Arnold, Ralph, 1909

Carman, E. P., and Bayes, F. S., 1961

Collom, R. E., 1918

Crawford, J. J., 1896

Davis, F. F., and Jennings, C. W., 1954

Eldridge, G. H., 1901

Hubbard, H. G., 1943

Jennings, C. W., 1957

Oakeshott, G. B., 1950

Page, B. M., and Holmes, C. N., 1945

Taff, J. A., 1908

Santa Maria

Arnold, Ralph, and Anderson, Robert, 1907b

Collom, R. E., 1918

Collom, R. E., 1929

Crawford, J. J., 1896 
Asphalt deposits - Continued

Santa Maria - Continued Eldridge, G. H., 1901

Gore, F. D., 1924

Skinner, D. A., 1952

Woodring, W. P., and Bramlette, M. N., 1950

Sisquoc

Adams, E. W., and Beatty, W. B., 1962

Summerland

Arnold, Ralph, 1907

Counties with significant asphalt deposits

Fresno

See Coalinga district

Kern

See McKittrick deposit

Kings

See Coalinga district

Los Angeles

Eaton, J. E., 1926

Eldridge, G. H., and Arnold, Ralph, 1907

Kew, W. S. W., 1924

Watts, W. L., 1896

Marin

Crawford, J. J., 1896

Vander Leck, Lawrence, 1922

Mendocino

Carman, E. P., and Bayes, F. S., 1961

Crawford, J. J., 1896

Holmes, C. N., Page, B. M., and Duncan, D. C., 1951

Jennings, C. W., 1957

Weber, A. H., 1887

Monterey

Bradley, W. W., Huguenin, C. A., Logan, C. A., and Waring, C. A., 1917

Carman, E. P., and Bayes, F. S., 1961

Collom, R. E., 1918

Crawford, J. J., 1896

Hart, E. W., 1966

Orange

Carman, E. P., and Bayes, F. S., 1961

Oakeshott, G. B., 1950

Parker, F. S., 1943

Watts, W. L., 1900

Santa Barbara

Bradley, W. W., Huguenin, C. A., Logan, C. A., and Waring, C. A., 1917

Carman, E. P., and Bayes, F. S., 1961

Collom, R. E., 1918

Cooper, A. S., 1898

Crawford, J. J., 1896

Dibblee, T. W., Jr., 1950

Dibblee, T. W., Jr., 1966 
Counties with significant asphalt deposits - Continued

Santa Barbara - Continued

Goodyear, W. A., 1887

Gore, F. D., 1924

Swaze, R. O., 1943

Vernon, J. W., and Slater, R. A., 1963

Watts, W. L., 1896

Whitney, J. D., 1865

Williams, M. D., and Holmes, C. N., 1945

San Bonito

Bradley, W. W., Huguenin, C. A., Logan, C. A., and Waring, C. A., 1917

San Luis Obispo

See Edna deposit

Santa Cruz

See Santa Cruz deposit

Ventura

Bradley, W. W., Huguenin, C. A., Logan, C. A., and Waring, C. A., 1917

Crawford, J. J., 1896

Dosch, M. W., 1965

Gore, F. D., 1924

Hilgard, E. W., 1885

Hilgard, E. W., 1890

Kew, W. S. W., 1924

Stipp, T. F., 1943

Taliaferro, N. L., Hudson, F. S., and Craddock, W. N., 1924

Watts, W. L., 1896

Geochemistry

Waterfall, L. N., 1943

Cooper, A. S., 1893

Cooper, A. S., 1899

Poth, E. J., and others, 1930

Rogers, G. S., 1919

Skinner, D. A., 1952

Metamorphism

Arnold, Ralph, and Anderson, Robert, 1907a

Mining and recovery

General references

Crawford, J. J., 1896

Dietzman, W. D., Carrales, M., Jr., and Jirik, C. J., 1965

Heizer, R. F., 1943

Hilgard, E. W., 1885

Orcutt, W. W., 1924

Peckham, S. F., 1882

Simm, C. N., 1964

Vander Leck, Lawrence, 1922

Kern County

Gates, C. F., and Ramey, H. J., 1958

Pack, R. W., 1920

Los Angeles County

Ball Associates, Ltd., 1965 
Mining and recovery - Continued

Mendocino County

Weber, A. H., 1887

Orange County

Burke, R. G., 1965

San Luis Obispo County

Ball Associates, Ltd., 1965

Shea, G. B., and Higgins, R. V., 1948

Ventura County

Dosch, M. W., 1965

Hilgard, E. W., 1890

Taliaferro, N. L., Hudson, F. S., and Craddock, W. N., 1924

Waterfall, L. N., 1943

Tar seeps

General references

Arnold, Ralph, and Kemnitzer, W. J., 1931

Carlson, C. R., 1962

Emery, K. O., 1960

English, W. A., 1916

Heizer, R. F., 1943

Pack, R. W., and English, W. A., 1915

Watts, W. L., 1894

Alameda County

Ball Associates, Ltd., 1965

Humboldt County

Oakeshott, G. B., 1950

Kern County

McKittrick tar seep

Church, C. C., 1968

English, W. A., 1921

Los Angeles County

Eaton, J. E., 1926

Marin County

Ball Associates, Ltd., 1965

San Luis Obispo County

Fairbanks, H. W., 1900

Santa Barbara County

Collom, R. E., 1929

Dibblee, T. W., Jr., 1950

Dibblee, T. W., Jr., 1966

Santa Clara County

Ball Associates, Ltd.; 1965

Davis, F. F., and Jennings, C. W., 1954

Ventura County

Hilgard, E. W., 1885

Taliaferro, N. L., Hudson, F. S., and Craddock, W. N., 1924

Oxnard oil field

Dosch, M. W., 1965

Simi oil field

Stipp, T. F., 1943

Waterfall, L. N., 1943 
Tar seeps (submarine)

California Div. Mines and Geology, 1959

Heizer, R. F., 1943

Vernon, J. W., and Slater, R. A., 1959

Wilson, T. A., and Mero, J. L., 1966

Tertiary

Ball Associates, Ltd., 1965

Dietzman, W. D., Carrales, M., Jr., and Jirik, C. J., 1965

Watts, W. L., 1894

Eocene

Stock, Chester, 1935

Tejon Formation

Arnold, Ralph, and Anderson, Robert, 1910

Miocene

Hoots, H. W., 1943

Jennings, C. W., 1957

Pack, R. W., and English, W. A., 1915

Vander Leck, Lawrence, 1922

Waterfall, L. N., 1943

Monterey shale

Arnold, Ralph, and Anderson, Robert, 1907b

Bramlette, M. N., 1946

Branner, J. C., Newsom, J. F., and Arnold, Ralph, 1909

Fairbanks, H. W., 1904

Gore, F. D., 1924

Hart, E. W., 1966

Pliocene

Holmes, C. N., Page, B. M., and Duncan, D. C., 1951

Dosch, M. W., 1965

Hoots, H. W., 1943

Jennings, C. W., 1957

Waterfall, L. N., 1943

Vein deposits

Hilgard, E. W., 1890

Smith, M. B., 1966

Watts, W. L., 1900

Tulare Formation

Church, C. C., 1968

Monterey Formation

Eldridge, G. H., 1901

Vertebrate fossils

VanderHoof, V. L., 1935

Eocene

Stock, Chester, 1930

Pleistocene

Merriam, J. C., and Stock, Chester, 1921

Merriam, J. C., and Stock, Chester, 1925

\section{Author List}

Adams, E. W., and Beatty, W. B., 1962, Bituminous rocks in California: California Div. Mines and Geology Min. Inf. Service, v. 15, no. 4, 11 p. 
In California, tar sands and similar deposits are most common around the margins of oil-producing basins where oil-containing formations are near the surface or where folds or faults have brought these formations near the surface. Nearly all the deposits occur in rocks of late Miocene to late Pliocene age. They are almost always associated with, or in the vicinity of, richly organic Miocene shales. Important deposits, from the standpoint of volume of available bituminous rock, include Edna (San Luis Obispo County), Sisquoc (Santa Barbara County), Casmalia and associated deposits (Santa Barbara County), Santa Cruz (Santa Cruz County), and McKittrick (Kern County). Estimates of "oil in place" reserves are presented in an accompanying table.

Arnold, Ralph, 1905, The Salt Lake oil field near Los Angeles, California: U.S. Geol. Survey Bull. 285-G, p. 357-361.

The Salt Lake oil field occupies an area of approximately 1 square mile, 7 miles west of the business district of Los Angeles, Calif. A small artificial lagoon, made by the removal of large quantities of brea, occupies a depression near the center of the southern part of the field. Great deposits of this brea occur in the immediate vicinity of the lagoon and north and northwest of it for a considerable distance. Numerous bones of extinct Pleistocene mammals, such as the saber-toothed tiger, elephant, giant sloth, cave bear, camel, and dog, are embedded in this brea and indicate not only the age of the deposits, but also that the conditions favorable for the accumulation of brea have existed since at least the middle or latter part of the Pleistocene Epoch. Heavy oil exudes from the banks of the lagoon and from some of the minor brea pits. The wells generally penetrate alluvium and clay impregnated with heavy oil in the first 50 to 100 feet. Author's text condensed.

Arnold, Ralph, 1907, Geology and oil resources of the Summerland district, Santa Barbara County, California: U.S. Geol. Survey Bull. 321, 93 p.

The Summerland oil district is in Santa Barbara County, 80 to 90 miles west-northwest of Los Angeles. This report gives a history of oil activity in the Summerland area from 1877 to 1905 and also discusses the physical and chemical properties of the oil. The most distinctive characteristics of the Summerland oil are its low gravity $\left(12^{\circ}\right.$ to $16^{\circ}$ Baumé $)$, its high percentage of asphalt (85.5 percent), its relatively high nitrogen content (1.25 percent), and its moderately low sulfur content ( 0.84 percent).

Arnold, Ralph, and Anderson, Robert, 1907a, Metamorphism by combustion of the hydrocarbons in the oil-bearing shale of California: Jour. Geology, v. 15 , no. 8 , p. $750-758$.

A unique variety of metamorphism has been at work in many regions of bituminous rocks in California, where a process of combustion of the hydrocarbon contents has altered the naturally white, soft shale to a rock of brilliant rose or brick-red color and rendered it hard and vesicular, like scoriaceous lava. The resemblance of the products to those of volcanoes and the existence of centers, like solfataras, where the burning has been going on during the last 50 years has given rise to the statement that there are living volcanic vents in Santa Barbara County. It is thought that brush fires, lightning, or spontaneous combustion started the burning and that the fire is supported by the bituminous material in the shale. Authors' text condensed. 
Arnold, Ralph, and Anderson, Robert, 1907b, Geology and oil resources of the Santa Maria oil district, Santa Barbara County, California: U.S. Geol. Survey Bull. 322, 161 p.

The Santa Maria oil district, comprising the Santa Maria, Lompoc, Arroyo Grande, and Huasna fields, is in northern Santa Barbara County and southern San Luis Obispo County. The larger part of the district is a basin region enclosed between the San Rafael and Santa Ynez Mountains and the Pacific Ocean. The Monterey shale (middle Miocene) is the chief oil-bearing formation. The oil accumulates in the fractured zones and porous sands of the lower part of the Monterey, where brittle shale predominates. The Monterey shale is largely organic in origin, being especially rich in diatoms. This report contains a detailed description of the asphalt seepages in the San Rafael Mountains.

Arnold, Ralph, and Anderson, Robert, 1910, Geology and oil resources of the Coalinga district, California, with a report on the chemical and physical properties of the oils by I. C. Allen: U.S. Geol. Survey Bull. 398, 354 p.

The Coalinga oil district occupies a strip of land about 50 miles long by 15 miles wide along the northeastern base of the Diablo Range on the southwest side of the San Joaquin Valley in western Fresno and Kings Counties in central California. The asphalt in this area is believed to have its source in the shales of the upper nembers of the Tejon formation (Eocene), which are petroliferous throughout the district. This oil is obtained by wells from the Miocene beds, which are petroleum bearing wherever they overlie the shales of the Tejon.

Ball Associates, Ltd., compiler, 1965, California, in Surface and shallow oilimpregnated rocks and shallow oil fields in the United States: U.S. Bur. Mines Mon. 12, p. 58-88.

Outcrops of bituminous rocks and shallow oil fields are known in 14 counties of California. Some are associated with oil seeps, as in Marin, Alameda, and Santa Clara Counties. The rocks containing bitumen and oil are Miocene to Pleistocene sandstones, except for Mesozoic sandstones in Humboldt, Fresno, and Los Angeles Counties. The coastal areas contain many oil seeps, most of them associated with fractured Miocene shale. Large deposits in San Louis Obispo and Santa Barbara Counties have been investigated for commercial oil-mining possibilities, but, so far, mining has not appeared to be economic in competition with oil-well oil. Recently developed thermalrecovery techniques have made additional, low-gravity oil-well crude available, tending to delay the advent of mined oil. The oil reserves estimated recoverable from oil sands by mining exceed 200 million barrels. The largest single reserve, Edna, in San Luis Obispo County, is more than 141.4 million barrels. Author's summary condensed.

Ball, M. W., 1951, Report on oil-impregnated strippable deposits in California as of May 22, 1950, Appendix C, in The synthetic liquid-fuel potential of California: U.S. Army Corps of Engineers, Summary report for the U.S. Bureau of Mines, Department of the Interior: Ford, Bacon \& Davis, Inc., Engineers.

Surface or near-surface oil-impregnated strippable deposits are known to 
exist in 12 western California counties. The deposits lie generally in the petroleum-producing areas of the State, on both sides of the Coast Range. The location and a brief description of these deposits are given. Two counties, San Luis Obispo and Santa Barbara, contain strippable deposits of at least 10 million tons wtihin a 5-square-mile area, in vertically continuous beds at least 15 feet thick. These beds yield more than 10 gallons per ton and are overlain by not more than their own thickness in overburden. The general geology, character of the bitumen, and reserves for San Luis Obispo and Santa Barbara Counties are tabulated.

Bradley, W. W., Huguenin, C. A., Logan, C. A., and Waring, C. A., 1917, The counties of Monterey, San Benito, San Luis Obispo, Santa Barbara, and Ventura, pt. 5, in Fifteenth Report of the State Mineralogist: California Jour. Mines and Geology, no. 15, p. 730-754.

The asphalt and bituminous rock deposits of the five counties are discussed individually and in detail. The Higgins Mine, 1 mile south of Carpinteria Station in Santa Barbara County, was working in 1915. There, beds of bituminous sands ranging in thickness from 12 to 20 feet, lie flat in a shallow V-shaped trough of underlying shales. This is a continuation of the deposit known as Los Conchas mine. The sands are covered by 4 feet of soil, and the bituminous rock contains 18 to 20 percent bitumen. By 1915 the mining of natural asphalt had been replaced by the material yielded by crude-oil distillation, as it was more uniform in quality and more cheaply obtained. The manufactured asphalt had a wide market, especially in Canada and Germany, but was curtailed by World War I.

Bramlette, M. N., and Daviess, S. N., 1945, Stratigraphy as related to oil possibilities of the Salinas Valley, California: U.S. Geol. Survey Oil and Gas Inv. Prelim. Map 24.

Map shows outcrops of bituminous sandstone.

Branner, J. C., Newsom, J. F., and Arnold, Ralph, 1909, Description of the Santa Cruz quadrangle [California]: U.S. Geol. Survey Geol. Atlas, Folio 163.

The bituminous rock of the Santa Cruz quadrangle is a porous, loose sandstone impregnated with asphaltum, a petroleum residue. The most important deposits in the quadrangle are those on the southwestern slope of Ben Lomand Mountain, 4 to 6 miles northwest of Santa Cruz. The bituminous sandstones lie near the base of the diatomaceous shale, referred to as the Monterey formation. The structure is monoclinal, with a gentle southwest dip; hence, the asphalt-bearing strata crop out along the sides of the southwestward-flowing streams where the streams have cut down to or nearly to the bottom of the shale. At many places in this district the sandstone beds are more or less bituminous, but at only the one locality mentioned are they of commercial value. Authors' text condensed.

Burke, R. G., 1965, Combustion project is making a profit: Oil and Gas Jour., v. 63 , no. 3 , p. $44-46$.

One of the oldest fireflood projects (March 1958) is being enlarged to cover a substantial part of a 575-acre lease in Orange County, Calif. The project, 
operated by an independent Texas oil firm, is in the West Newport field. Seven combustion-drive projects are operating in the B-zone of the Banning lease. Nearly one-third of the wells on the lease are affected by combustion operations. Gravity of the oil is $15.2^{\circ}$. Since 1960 , the combustion-drive operation has been on a commercial basis. Production now amounts to 562,000 barrels of combustion oil. The lease in its first 20 years produced 10 million barrels of oil, but operators expect to recover the next 10 million barrels by thermal drive in about one-third of that time. As in many reservoirs, with a heavy viscous crude, the percentage of recovery by primary methods at the Banning lease was small. Before combustion drive was applied, the 100 wells each averaged about 11 barrels of oil per day. At present, about 35 to 40 wells are affected. The response ranges from a 3-barrel-per-day well making 15 to 20 barrels per day to an 11-barrel-per-day well that is now producing 50 to 60 barrels per day. Author's text condensed.

Carlson, C. R., 1962, Oil seeps and early petroleum development in northern California, in Bowen, O. E., Jr., ed., Geologic guides to the gas and oil fields of northern California: California Div. Mines and Geology Bull. 181 , p. 23-26.

As the early prospectors searched for oil, they found extensive oil and gas seeps in the hills and tributary valleys west of Sacramento Valley. These seeps were located in the Knoxville formation, in the younger "Chico" beds of the Upper Cretaceous, and in the intrusive serpentines within the Knoxville formation near Franciscan contacts. The most widely known oil and gas seeps occurred in the western part of Colusa and Glenn Counties near Wilbur Springs. Several operators drilled unsuccessful shallow wells near these seeps. No large oil field has yet been discovered in or near the Sacramento Valley, though considerable money and effort have been spent. Author's text condensed.

Carman, E. P., and Bayes, F. S., 1961, California, in Occurrence, properties, and uses of some natural bitumens: U.S. Bur. Mines Inf. Circ. 7997, 42 p.

Pure asphalt deposits in California occur in Kern County in the Asphalto region, about 50 miles west of Bakersfield. These are in the form of both springs and veins, and the overflow of the springs has covered an area of about 7 acres. Other California deposits are found at Tar Springs Creek (a seepage deposit 20 miles southeast of San Luis Obispo, in San Luis Obispo County) and in veins in the La Graciosa Hills (about 4 to 5 miles east of Graciosa in the Santa Maria region of Santa Barbara County). In California, deposits of asphaltic sand or sandstone are found in Mendocino, Santa Cruz, Monterey, San Luis Obispo, and Orange Counties, and deposits of asphaltimpregnated shale, asphalt veins, and asphaltic sands are located in Santa Barbara County. Authors' text condensed.

Church, C. C., 1968, The McKittrick tar seeps, in Geology and oilfields, west side. southern San Joaquin Valley: A.A.P.G., S.E.G., S.E.P.M. Pacific Sec. Joint Ann. Field Trip Guidebook: Am. Assoc. Petroleum Geologists, Pacific Sec., Los Angeles, Calif., p. 86-92.

The McKittrick tar seeps comprise one of the most extensive deposits of asphalt in California. The extensive seeps follow the crest of the McKittrick 
oil field, which is a narrow structure about $4 \frac{1}{2}$ miles long and half a mile wide. The tar seeps find their way to the surface through crumpled and faulted Miocene cherty and diatomaceous shale. These shales have been thrust over the younger Tulare beds at a low angle, much in the nature of a gigantic landslide. In addition to the more extensive asphalt-soaked alluvium and sand, there are numerous asphalt veins, largely confined to the Tulare Formation in the southeastern part of the district. These veins are as much as 100 feet long and from a few inches to 8 feet wide. The vein material is a mixture of asphalt and sand; in a few instances, the asphalt makes up as much as 70 percent of the mixture. Author's text condensed.

Collom, R. E., 1918, Santa Barbara, San Luis Obispo, Monterey, and Santa Clara Counties, in Second Annual Report of the State Oil and Gas Supervisor of California: California State Mining Bur. Bull. 82, p. 198-230.

An examination of the asphaltum deposits of this district shows that the asphaltum originated directly and locally from eroded Monterey shale, with the possible exception of the deposit at the Fugler Point asphalt mine. A study of the structure of the Monterey in the Santa Maria district shows that the asphaltum and brea occur at the top of anticlinal folds, where oil-bearing Monterey beds have been eroded and the oil released. Within the Fugler Point asphalt mine, there appears to be a Fernando oil sand, 11/2-2 feet thick. The main body of asphaltum appears to have no definite system of bedding and is commonly described as a "blow-out." From knowledge of other brea deposits in the district, it is reasonable to assume that this asphaltum is the remains of oil that has been forced, through fractures, into the Fernando from the underlying Monterey beds. Author's text condensed.

Collom, R. E., 1929, Oil accumulation and structure of the Santa Maria district, Santa Barbara County, California, in Structure of typical American oil fields, v. 2, Am. Assoc. Petroleum Geologists, Tulsa, Okla., p. 18-22.

The producing fields of the Santa Maria district, and any other possible reservoirs of oil that are as yet undiscovered, represent only a small part of the original petrolifercus product of these organic shales. In many outcrops of lower Monterey beds of the Santa Maria district, the innumerable small fractures and crevices in the shales are filled with tar. Heavy oil seeps from the shales in some places. In Foxen Canyon is an old inclined pit, sunk on a stratum of steep-tilted shale, the fractures of which are filled with gilsonite. Wherever the older strata of Monterey are exposed in Santa Barbara County, whether in the San Rafael Mountains or along the coast near Santa Barbara, tar fills the fractures, or heavy oil exudes along some fracture plane. On the crest of the hills near the Casmalia field is a great mass of so-called "oil shale." Actually, this material is a porous diatomaceous shale saturated with crude oil. Author's text condensed.

Cooper, A. S., 1893, Red shales as connected with the genesis of bitumen in California: Scientific American, Supplement 939, p. 15002-15003.

Red shales in California are the result of chemical heat. Water percolating and circulating through porous and seamed strata, by its solvent action, accumulates mineral ingredients. These mineral-saturated waters come into contact with other minerals existing in the shales and, by chemical reactions, 
produce heat. This chemical heat distills petroleum from the carbonaceous shales and oxidizes the carbonate and sulfide of iron, producing the red color of the shales. The water of different temperatures, charged with mineral ingredients, will frequently rise by hydrostatic pressure through fissures and faults to the surface accompanied by the bitumen. Bituminous deposits may occur where red shales are not actually visible, but unquestionably the shales exist close by, as they are the stills in which petroleum is distilled from carbonaceous matter by the action of chemical heat, water, and reactive chemicals. Author's text condensed.

Cooper, A. S., 1898, A bituminous rock deposit in Santa Barbara County, California: Eng. Mining Jour., v. 66, no. 10, p. 278-279.

When not reduced by erosion, this bituminous formation averages 200 feet in thickness. The bituminous formation is composed of several conformable beds of sand of different degrees of fineness and quality. Interspaces in the sands are filled with bitumen. Because of the difference in size and shape of the sand grains composing the beds, bitumen content varies from 8 to 15 percent by weight. For the first 1 or 2 feet below the surface, the bitumen is brown and friable, mainly as a result of evaporation of its volatile parts and probably partly as a result of polymerism; this is underlain by 6 inches of very tough material. To produce these conditions, long exposure to atmospheric influences is required. Below the tough layer, the bitumen becomes increasingly liquid with great depth, until finally it becomes a thick oil. In fact, the bitumen liquefies so rapidly when removed from atmospheric influences that only a small part of a deposit is suitable for street-paving purposes when the bituminized sand is used in its natural state for that purpose. Author's text condensed.

Cooper, A. S., 1899, The genesis of petroleum and asphaltum in California, in Sixteenth Report of the State Mineralogist: California Jour. Mines and Geology, no. 16, p. 3-66.

It can be tentatively stated that fossil bitumens are derived from terrestrial and marine vegetation, deposited in sedimentary strata, then changed to carbonaceous matter and afterwards distilled by the heat of metamorphism. In the decomposition of vegetable tissue when air is wholly or partially excluded from it, as, for example, when buried in the ground, the constituent elements of the vegetable tissue rearrange themselves mutually into new products: the oxygen gradually unites with the carbon to form carbonic acid, which separates and leaves as a residue substances rich in carbon and hydrogen. In this way bituminous coal, peat, and lignite have been formed from vegetable matter. Where metamorphic rocks underlie formations bearing carbonaceous material, petroleum may be distilled. Author's text condensed.

Crawford, J. J., 1896, Asphalt and bituminous rock in Thirteenth Report of the State Mineralogist: California Jour. Mines and Geology, no. 13, p. 35-45.

Asphalt and bituminous rock occur in Kern, Marin, Mendocino, Monterey, San Luis Obispo, Santa Barbara, Santa Clara, Santa Cruz, and Ventura Counties. This report lists the various mines in each county and describes the mining operations of each. 
Davis, F. F., and Jennings, C. W., 1954, Mines and mineral resources of Santa Clara County, California: California Jour. Mines and Geology, v. 50, no. 2, p. 321-430.

Some of the earliest oil prospecting in California began in Santa Clara County, principally around oil and asphalt seeps at Sargent and Moody Gulch. Drilling in the Sargent area dates back to 1886. Production never amounted to more than a few thousand barrels annually and gradually diminished until the field was abandoned in 1948. The Moody Gulch field was discovered in 1878 and has been productive to date. Oil and asphalt seeps are very prominent in this region, especially along La Brea Creek, where a single seep may cover as much as 1 acre. In nearly every instance, the seeps are found at the contact between the Monterey and the overlying Purisima formations or along the faults in them. Authors' text condensed.

Dibblee, T. W., Jr., 1950, Geology of southwestern Santa Barbara County, California: California Div. Mines and Geology Bull. 150, 95 p. [p. 75].

Four deposits of asphalt in the form of tar-impregnated sands occur in this area - one on the south coast and three in the Purisima Hills. None has been quarried. Along the sea cliff within $1 \frac{1}{2}$ miles west of Gaviota Beach an asphalt-impregnated sand is exposed. In the eastern Purisima Hills, a large deposit of tar-soaked sand is exposed at the base of the Sisquoc. This deposit consists of very fine sand heavily impregnated with asphalt. It is about 75 feet in maximum thickness, and extends about 1 mile, dipping steeply north into a syncline. Redrock Mountain, in the central Purisima Hills, is formed by a large deposit of tar-soaked sand. This deposit consists of fine sand of the Careaga formation, which is about 50 feet thick and caps the mountain. Two erosional remnants of this tar sand occur about 1 mile down the spur to the southwest. The tar sand of Redrock Mountain is underlain by highly bituminous shale of the lower Sisquoc which has been locally burned, causing it to become brilliant red and locally scoriaceous. A small deposit of tar sand at the Lompoc oil field in Purisima Canyon consists of medium-grained Careaga sand impregnated with asphalt about 25 feet thick. Author's text condensed.

Dibblee, T. W., Jr., 1966, Geology of the central Santa Ynez Mountains, Santa Barbara County, California: California Div. Mines and Geology Bull. 186, 99 p. [p. 84-89].

Natural seeps of tar, oil, and gas are common in the coastal area south of the Santa Ynez Range, but none are known to occur in the area north of it. Most of these seeps issue from the Monterey Shale and from some of the younger formations on or near the sea cliffs. These bituminous seeps in the Monterey and younger formations of the coastal bluffs are of asphaltic tar or heavy black asphalt-base oil that are probably indigenous to the Monterey Shale. There are two deposits of tar or asphaltum - one at Carpinteria and one at More's Landing, just southeast of the Galeta gas field. The Carpinteria tar pits are near the sea wall one-half mile southeast of Carpinteria. The pits are roughly 25 feet deep and cover several acres. Author's text condensed.

Dietzman, W. D., Carrales, M., Jr., and Jirik, C. J., 1965, California, in Heavy crude oil reservoirs in the United States - A survey: U.S. Bur. Mines Inf. Circ. 8263,53 p. 
The productive formations in California range in age from Pleistocene to Jurassic, but most of the heavy oil is produced from Tertiary sands. Depths of heavy oil reservoirs range from near the surface to about 13,650 feet; the majority of the reservoirs are at depths between 1,000 and 4,000 feet. About 50 percent of the reservoirs have a productive thickness of at least 150 feet, and 30 percent have a productive thickness of more than 300 feet. Producing mechanisms are predominantly solution-gas expansion or water drive, or combinations of the two. More than 150 steam-injection projects and more than 25 in-situ combustion projects have been initiated in this area of California.

Dosch, M. W., 1965, Pliocene tar sands in Oxnard oil field, Ventura County, California: California Div. Oil and Gas, California Oil Fields Summ. Operations, v. 51, no. 2, 108 p.

Tar sands are found at or near the base of the Pico formation over a considerable part of the Oxnard field. These tar sands in the eastern part of the field are known as the Vaca tar sands, and the stratigraphically lower tar sands in the western part of the field are called the lower tar sands. Pliocene tar sands were penetrated in many wells and in a few cases attempts were made to produce from them; however, these efforts were unsuccssful as the crude was too viscous and carried large amounts of sand. Steam-recovery methods were tried in 1964, and at least one well using this method is still producing. The source of the tar in the Pliocene sands is probably the underlying Miocene shales. The viscous nature of the crude and the thorough saturation of the sands indicate that these sands may have been deposited upon Miocene tar seeps.

Eaton, J. E., 1926, A contribution to the geology of Los Angeles Basin, California: Am. Assoc. Petroleum Geologists Bull., v. 10, no. 8, p. 753-767.

Surface indications of oil in the Los Angeles Basin occur locally, but are not particularly impressive when compared with other productive districts in California. The largest concentration occurs at the Salt Lake pool in western Los Angeles, where a lake covering several acres was formed during Quaternary time by exuding petroleum. A few oil seeps southeast of the Elysian Hills and in the Puente Hills, together with one large seep under the ocean west of Redondo, are the extent of "live" evidences of petroleum. An important indication of oil is the commonly bituminous nature of the PuentePico contact where exposed. The occurrence of bituminous strata at or near this contact is widespread, although the deposits themselves are not ordinarily of large volume. Author's text condensed.

Eldridge, G. H., 1901, California, in The asphalt and bituminous rock deposits of the United States: U.S. Geol. Survey 22d Ann. Rept., pt. 1-B, p. 209452 [p. 365-402].

The deposits of asphalt and bituminous sandstones in California are found in the immediate region of the Coast Range. They are confined chiefly to that part of the range lying south of the Bay of San Francisco. The purer variety of asphalt has been found (1) in the vicinity of McKittrick in Kern County, near Santa Maria, in the Graciosa and Azufre Hills; and (2) 6 or 7 miles west of Santa Barbara on the coast. Bituminous sandstones occur at Point Arena, in the north, and at several localities in the south, notably near Santa 
Cruz, San Luis Obispo, Los Alamos, and Carpinteria. The asphalt and bituminous rock deposits in California are confined to the formations of the Neocene and particularly to the Monterey shale and the rocks immediately above and below. The Monterey formation is of particular importance; for almost the entire length of the State, its terrain is more or less conspicuously marked with petroleum or maltha seepages. The shales of the Monterey are generally bituminous, and some of their more arenaceous and porous members are especially rich, having received an inflow of petroleum from their associates. It is in the shales of the Monterey, too, that veins of the more solid bitumens, mixed with clastic material from the country rocks, are found. Veins of this type are conspicuous in the vicinity of Santa Maria, Santa Barbara, and Asphalto. Author's text condensed.

Eldridge, G. H., and Arnold, Ralph, 1907, The Santa Clara Valley, Puente Hills, and Los Angeles oil districts, southern California: U.S. Geol. Survey Bull. 309, 266 p. [p. 139-141].

The discussion of asphalt in this report is confined to the Los Angeles district. A history of asphalt study from the time of the Pacific Railroad expeditions in 1853 and 1855 is given.

Emery, K. O., 1960, Petroleum, in The sea off southern California - A modern habitat of petroleum: New York, John Wiley \& Sons, Inc., p. 320-322.

Analyses of tar from a seep on the south shore of Palos Verdes Hills by Richfield Oil Corp. show it to have a melting point of $87^{\circ} \mathrm{C}$ and a specific gravity of 1.06 , to be 63 percent soluble in ether and to contain 7.9 percent sulfur and 0.14 percent ash, of which one-third consists of vanadium and nickel. Where the tar masses encounter boulders or bedrock along the shore, they stick to the surface and become a semipermanent feature. In some places it remains long enough to protect the underlying rock from erosion, causing these areas to stand out in relief. Navigational charts published by the U.S. Coast and Geodetic Survey indicate oil seeps at the head of Redondo Submarine Canyon and on the shelf west of San Miguel Island. Other seeps have been observed near Point Conception to about 8 kilometers east near Coal Oil Point, Summerland, and Elwood, and a few kilometers east of Anacopa Island. Author's text condensed.

English, W. A., 1916, Geology and oil prospects of the Cuyama Valley, California: U.S. Geol. Survey Bull. 621-M, p. 191-215.

The largest oil seep reported in the Cuyama Valley occurs in the bed of the Cuyama River south of Whiterock Bluff. The river has cut down through about 20 feet of Quaternary stream deposits and is flowing on bedrock, the diatomaceous shale of the Whiterock Bluff member of the Santa Margarita formation. During an earlier epoch when the stream gravels and sands were being deposited, a number of oil pools were formed here, some as much as 100 yards across. The oil in these pools saturated the surface sand, which was later covered by sediment and preserved and which is now traceable along the vertical riverbanks as thin strata of oil sand interbedded with white sand and clay. At one place, which may have been the original seep, an asphaltlike oil has escaped from the underlying shale very recently. The shale near this seep has irregular dips, and the oil may have come up along or close to a fault. Author's text condensed. 
English, W. A., 1919, Geology and oil prospects of the Salinas Valley-Parkfield area, California: U.S. Geol. Survey Bull. 691-H, p. 219-250.

The Salinas shale (upper formation of the Monterey group, commonly known as the "Monterey shale") and the shale of the overlying Santa Margarita formation are well developed in this region. Each is economically important as having been the original source of at least some oil. The direct evidence of origin of oil in these shales is the presence of seeps or tar sands in the shales or adjacent rocks. The oil and tar in the Pleyto district and west of San Ardo originated in the Salinas shale. Oil from the shale of the Santa Margarita(?) formation forms seeps in the Parkfield district. The Mylar Asphalt Quarry (about 10 miles north of San Ardo) contains oil derived from the Santa Margarita (?). Author's text condensed.

English, W. A., 1921, Geology and petroleum resources of northwestern Kern County, California: U.S. Geol. Survey Bull. 721, 48 p.

This area was one of the first in the State prospected for oil. Wells were drilled near the seeps in this area during the early 1860's. Even before that time, the old settlers are reported to have used the tarry oil to grease their wagons. The presence of oil seeps is dependent on the thickness of the beds overlying the oil-bearing horizons and their permeability to the upwardmigrating oil; thus, if the cover is thick or especially impervious, there will be no seeps, even though the underlying rocks contain a large amount of oil.

Fairbanks, H. W., 1900, The oil-yielding formations of San Luis Obispo County, in Watts, W. C., Oil- and gas-yielding formations of California: California Div. Mines and Geology Bull. 19, p. 143-144.

A part of the Coast Ranges in San Luis Obispo County is characterized by extensive deposits of bituminous rock. There are also numerous springs of thick, tarlike oil. In some places the oil from these springs has impregnated sandstones and formed bituminous rock; in other places it has accumulated in great quantities on the surface, as in the valley of Tar Spring Creek. The oil-producing formation is the Monterey formation (Tertiary). The rocks are mainly of organic origin, having been formed from the skeletons of fish and microscopic sea organisms. Author's text condensed.

Fairbanks, H. W., 1904, Description of the San Luis quadrangle [California]: U.S. Geol. Survey Geol. Atlas, Folio 101.

The important deposits of bituminous rock in the San Luis 30-minute quadrangle (west-central San Luis Obispo County) are chiefly in those parts of the Pismo formation that overlie the bituminous Monterey shale. The characteristic feature of the Pismo formation is its soft, porous sandstone, which is easily permeated by oil and bitumen. Although springs of tar and oil occur in all the divisions of the Tertiary in California, the most important source of these materials appears to be in the Miocene bituminous shales (Monterey shale). At points where the tar or oil springs issue directly at the surface from the hard, compact Monterey shale, the conditions are not favorable for the preservation of bituminous matter. For the material to collect in large quantities, a porous reservoir is needed. Wherever the Pismo formation occurs, such a reservoir is afforded by the thick beds of slightly cemented sand. The sandstone thus impregnated is more resistant to weathering than when not affected. Thus, wherever there is a large body of bitumen, prominent topo- 
graphic features may result, such as the picturesque cliffs below Edna. Author's text condensed.

Gates, C. F., and Ramey, H. J., 1958, Field results of South Belridge thermalrecovery experiment: Soc. Petroleum Engineers, A.I.M.E. Trans., v. 213, p. 236.

This field test was conducted in the South Belridge field, Calif. The test pattern was a single 2.5-acre five-spot pattern in the 700-foot-deep Tulare sand. Results indicated the technical feasibility of producing high-viscosity low-gravity crude oils by thermal means, and demonstrated that heavy oils could be moved rapidly over considerable distances by thermal drive and that high-percentage recoveries of oil could be effected. The bulk of the oil recovery came after arrival of the burning front at a production well. However, rapid corrosion and high-temperature failure of conventional steel pipes and equipment occurred both below and above surface. Stainless steel gave more satisfactory performance under these conditions than did conventional steels. Authors' abstract condensed.

Goodyear, W. A., 1887, Petroleum, asphaltum, and natural gas in Santa Barbara County, in Seventh Report of the State Mineralogist: California Jour. Mines and Geology, no. 7, p. 89-91 [1888].

This report summarized the development work done in Santa Barbara County to 1888 and briefly describes the asphalt deposits at Carpinteria and at Hill's Ranch.

Gore, F. D., 1924, Oil shale in Santa Barbara County, California: Am. Assoc. Petroleum Geologists Bull., v. 8, no. 4, p. 459-472.

The oil shale of California should not be confused with the shales of other parts of the United States and foreign countries, as it is different both physically and chemically. It is, in a truer sense, an oil-saturated diatomaceous shale from which oil may be extracted by use of any well-known solvent, such as benzol, chloroform, or pyridine. The principal deposits of oil shale occur in Santa Barbara and Ventura Counties in and near the currently producing oil fields. The production of oil in the Santa Maria, Casmalia, and Lompoc oil fields is from this oil shale, commonly termed "brown shale." The larger beds of bituminous shale appear in the lower calcareous and flinty series of the Monterey shales of middle Miocene age. Author's text condensed.

Hail, W. J., Jr., 1957, California, in Reconnaissance for uranium in asphaltbearing rocks in the Western United States: U.S. Geol. Survey Bull. 1046-E, p. 55-85 [p. 61-67].

The asphalt-bearing rocks in California generally appear to be more favorable for occurrence of uranium than those examined in the other Western States. In 11 of the 13 California areas, the average uranium content of the ash of the extracted oil ranged from 0.023 to 0.376 percent. Almost all the California asphalts examined occur in Miocene or Pliocene rocks. The deposits in the Edna area, San Luis Obispo County, contain the highest concentration of uranium of all the deposits examined in the United States. The uranium content of seven samples collected in the Edna area ranges from 0.035 to 1.9 percent and averages 0.376 percent in the ash of the extracted oil. Author's text condensed. 
Hart, E. W., 1966, Bituminous sandstone, in Mines and mineral resources of Monterey County, California: California Div. Mines and Geology County Rept. 5, 142 p. [p. 29-31].

The most important bituminous rock deposits in Monterey County are the Mylar, San Antonio River, San Ardo, and King City deposits. The King City deposit is 4 miles west of King City in the $\mathrm{S}^{1 / 2}$ sec. 28 , the $\mathrm{NE}^{1 / 4}$ sec. 33 , and the $\mathrm{W}^{1 / 2}$ sec. 34, T. 19 S., and sec. 3, T. 20 S., R. 7 E. (Mount Diablo meridian). The tar sands occur in a sandy sequence that forms a transitional zone between siliceous Monterey shale and the overlying Santa Margarita sandstone. The Mylar quarry is 9 miles northeast of King City in the SE $1 / 4$ sec. 15, T. 19 S., R. 9 E. The bituminous sandstone is an asphalt-bearing arkose which crops out over an area 100 feet by 1,500 feet. The bituminous beds lie in the basal part of a marine Pliocene formation, which is in fault contact with granitic rocks to the northeast. The San Antonio River deposit is 6 miles southwest of Bradley, in the SW1/4 sec. 35, T. 24 S., R. 10 E. The Pliocene strata have been mapped and described as the Etchegoin Formation, which lies unconformably on the Salinas Shale (Monterey Formation) of Miocene age. Others have described the bituminous beds as being part of the Paso Robles Formation and (or) Monterey Formation. An analysis of a bituminous sandstone sample contained 10.49 percent bitumen. The San Ardo deposit is 2 miles southwest of San Ardo. There, the bituminous sandstone beds crop out on the east flank of the San Antonio Hills for a distance of about 5 miles. This sequence has been assigned to a transitional zone between the Monterey and Santa Margarita Formations by Bramlette and Daviess (1945, map sheet). Two samples of bituminous sandstone from this deposit contained 3.58 percent and 8.9 percent oil. Author's text condensed.

Heizer, R. F., 1943, Aboriginal use of bitumen by the California Indians, in Geologic formations and economic development of the oil and gas fields of California: California Div. Mines and Geology Bull. 118, p. 74.

Bitumen, dug from surface land seepages or collected along the beaches from Point Conception to San Diego as lumps exuded from submarine seeps, was an important adjunct to native technology. It served as a caulking material for boats, as an adhesive, and as waterproofing for baskets. Along the Santa Barbara Channel, the Chumash Indians had perfected a canoe made of many small planks tied, or "sewed" firmly together with small ropes. This unique canoe was essential to the lives of the natives, but it could not have been constructed without asphaltum to caulk the plank interstices and binding holes. The Chumash Indians also used bitumen liberally for such purposes as an adhesive to affix arrowheads to the shafts; for mending broken stone vessels or pestles; as an adhesive for stemming pipes with bone mouthpieces; as a mastic, or setting, for inlaying small pieces of shell, as decorations; and as a filling to run into incised lines to bring out the designs in shades of contrasting black. Author's text condensed.

Hilgard, E. W., 1885, The asphaltum deposits of California, in Mineral resources of the United States for 1883-84: U.S. Geol. Survey Mineral Resources of the United States, p. 938-948.

This report is a general discussion of the asphalt deposits in California 
by county, especially the glacier-like brea and streams of slow-moving tar in Ventura County. It gives methods of mining the asphalt and an assay report for each major deposit known in 1885.

Hilgard, E. W., 1890, Report on the Asphaltum mine of the Ventura Asphalt Co., in Tenth Report of the State Mineralogist: California Jour. Mines and Geology, no. 10, p. 763-772.

This detailed report includes a cross section, a topographic map, and an assay table of the Ventura Asphalt Co. mine, located 5 miles west-northwest of the town of San Buenaventura, Ventura County, Calif. This vein was indicated on the surface by a seam 7-15 inches thick. But, when stripped, the vein was found to increase rapidly both horizontally and downward. At the depth of 65 feet from its outcrop and 60 feet horizontally from the same, its thickness is 5 feet, and the quality of the material has improved. The material is a brownish-black uniform mass that has conchoidal fracture, dull on the break, and that shows a light- to full-shade-brown streak. It yields somewhat under light blows of the hammer, but splinters under heavy ones, so it can be readily blasted. The specific gravity is about 2 . On heating to about $450^{\circ} \mathrm{F}$, it softens to a mushy condition, but does not attain fusion without the aid of a "fluxing," or thinning, substance. An attempt to replace the process of drilling blastholes with the use of hot iron bars failed to give satisfactory results because the product of this mine is a ready-formed intimate mixture of remarkably firm and fixed bitumen that contains very little of the more volatile oils. Author's text condensed.

Holmes, C. N., Page, B. M., and Duncan, D. C., 1951, Bituminous sandstone deposits of Point Arena, Mendocino County, California: U.S. Geol. Survey Oil and Gas Inv. Map OM-125, with text.

Asphalt-bearing sandstone beds in the Monterey shale of Miocene age crop out on the sea coast just west of the town of Point Arena in Mendocino County. A sequence of interbedded shale, siltstone, and sandstone, 500 feet thick, contains six asphalt-bearing sandstone beds ranging in thickness from 1 to 3 feet. The beds crop out along parts of the east and south rim of a small northwestward-plunging syncline and underlie an area of less than half a square mile. Reserves of asphalt-bearing sandstone are estimated to be about 3.2 million tons.

Hoots, H. W., 1943, Origin, migration, and accumulation of oil in California, in Geologic formations and economic development of the oil and gas fields of California: California Div. Mines and Geology Bull. 118, p. 253-276.

Seepages and impregnations of heavy oil and tar occur in outcrops of Pliocene and Miocene shale, siltstone, and sandstone at many places throughout central and southern California. Burned red shale, apparently having resulted from combustion of the oil-impregnated shale, covers extensive areas. The Miocene shales are the most probable source of oil. Phosphatic material is abundant in laminae, nodules, and lenses, and the bedding planes commonly carry spots of oil considered to be indigenous. The Orcutt and Santa Maria Valley Miocene oil zone contains a bituminous nodular phosphatic shale that immediately overlies the basal Miocene oil zone of the Playa del Rey and El Segundo fields in the Los Angeles Basin. Author's text condensed. 
Hubbard, H. G., 1943, Mines and mineral resources of Santa Cruz County, California: California Jour. Mines and Geology, v. 39, no. 1, p. 16-35.

The deposits of asphaltic and bituminous rock in Santa Cruz County have long been known and utilized. The material is a porous loose fine-grained to fairly coarse grained sandstone that is impregnated with asphaltum. These so-called bituminous rock deposits are extensive, but are only developed in a few places. This report contains a map of Santa Cruz County, showing the location of the quarries and description of operations at bituminous rock properties.

Jennings, C. W., 1957, Asphalt and bituminous rock, in Mineral commodities of California: California Div. Mines and Geology Bull. 176, p. 59-70.

Known deposits of bituminous rocks in California are numerous, and they generally lie within the limits of the distribution of marine Miocene and Pliocene formations in and around the margin of the Tertiary basins. This report summarizes work done on the bituminous rock near Santa Cruz, Santa Cruz County; Casmalia, Santa Barbara County; Edna, San Luis Obispo County; McKittrick, Kern County; and Point Arena, Mendocino County. It also includes a brief description of the bituminous sands east of Newhall and of the famous tar pits at Rancho La Brea in west Los Angeles.

Kew, W. S. W., 1924, Geology and oil resources of a part of Los Angeles and Ventura Counties, California: U.S. Geol. Survey Bull. 753, 202 p.

In California, oil seepages, brea deposits, outcropping oil sands, and burned shale are important criteria in determining the favorability of any locality for oil. Although surface indications of the above-named types do not prove that paying quantities of oil may be obtained, they are evidence that oil is present in certain strata in the region. The surface evidences of oil are closely associated with the formations in which the oil originates (Martinez, Meganos, Tejon, and Modelo), as well as with the formations into which it has migrated (Sespe, Pico, and Saugus). These formations include all the strata above the Upper Cretaceous Chico formation. The most important seeps and oil sands occur in the Modelo formation; Los Angeles and Ventura Counties have been noted since the early days for their numerous and striking oil indications, which are conspicuous in the Santa Clara valley. On the basis of these indications of petroleum, the first real oil industry in California was started in Pico Canyon, west of Newhall. Author's text condensed.

Kramer, A. J., and Smith, H. M., 1924, Properties of typical crude oils from the producing fields of California: U.S. Bur. Mines Rept. Inv. 2595, 55 p.

This report classifies crude oils and gives properties and detailed analyses of typical samples.

Krueger, M. L., 1943, Arroyo Grande (Edna) oil field, in Geologic formations and economic development of the oil and gas fields of California: California Div. Mines and Geology Bull. 118, p. 450-452.

The Arroyo Grande oil field is about 3 miles north of the town of Pismo, on both sides of Pismo Creek, San Luis Obispo County. Enormous deposits of dry tar sands form precipitous cliffs adjacent to the Arroyo Grande field. This so-called bituminous rock is a sand whose interstices are impregnated 
with tarlike-petroleum residuum. Because of the superresistance to erosion of the inspissated oil-sand deposits, topographic prominences have been developed. This bituminous rock has previously been mined for road-surfacing material, and the supply is practically inexhaustible. Author's text condensed.

Merriam, J. C., and Stock, Chester, 1921, An occurrence of Pleistocene vertebrates in an asphalt deposit near McKittrick, California: Science, v. 54, no. 1406, p. $566-567$.

In the brea deposit near McKittrick, a surface stratum of hardened asphaltic material, in places, attains a thickness of several feet. This layer contains numerous remains of birds and mammals, apparently representing the Recent fauna, and overlies the deposit in which Pleistocene vertebrates are found. In excavating the older bed, dense accumulations of mammalian remains were found. This deposit is generally comparable to those at Rancho La Brea, with a few notable exceptions; for instance, shore birds, rare at La Brea, are abundant at McKittrick. The exhumed material was not so well preserved as that from the asphalt bed near Los Angeles, seemingly because the prevailing earthy matrix at McKittrick shows somewhat less impregnation by petroleum. Further collecting at the McKittrick locality will bring out the relationship between this assemblage and the Rancho La Brea fauna. The contrasting features that are recognized may result from a geographic separation of the two asphalt deposits. The environmental conditions of the two areas may have been slightly different, or the two areas may represent separate depositional stages of the Pleistocene.

Merriam, J. C., and Stock, Chester, 1925, A llama from the Pleistocene of McKittrick, California, in Papers concerning the Palaeontology of the Pleistocene of California and the Tertiary of Oregon: Carnegie Inst. Washington Pub. 347, p. 39-42.

In a provisional list of mammals from an asphalt deposit near McKittrick, Kern County, Calif., a slender-limbed camel was recognized as certainly distinct from the large Camelops hesternus known from Rancho La Brea. Further excavating at McKittrick has resulted in the collection of additional material of the small camel, as well as specimens of Camelops hesternus. The slender-limbed camel is undoubtedly closely related to the present-day llama of South America. This records for the first time the presence of the genus Lama in the Pleistocene of California, and possibly for the first time in North America. Authors' text condensed.

Oakeshott, G. B., 1950, Asphalt and bituminous rock, in Mineral commodities of California: California Div. Mines and Geology Bull. 156, p. 124-130.

Asphalt, bituminous rock, and tar seeps are found generally in the petroleum-producing areas of the State. The northernmost oil seeps in California are in southern Humboldt County, along the fault contacts between Upper Jurassic Franciscan rocks and Lower Cretaceous (?) shale. Seeps and bituminous rocks are found at numerous localities in the Coast Ranges, as far south as Orange County and around the borders of the San Joaquin Valley. This report discusses the Santa Cruz, Casmalia, Edna, McKittrick, and Rancho La Brea deposits. Author's text condensed.

Orcutt, W. W., 1924, Early oil development in California: Am. Assoc. Petroleum Geologists Bull., v. 8, no. 1, p. 61-72. 
This article gives a history of oil-industry development, particularly of the asphalt deposits to 1924 .

Pack, R. W., 1920, The Sunset-Midway oil field, California, Pt. 1 of Geology and oil resources: U.S. Geol. Survey Prof. Paper 116, 179 p.

The deposits of asphalt and seeps of oil in this region were known to the earliest settlers, but not until the late 1880 's was any attempt made to mine either the asphalt or the oil. In parts of the field where the oil is buried deeper than 2,000 feet, a zone of tar-filled sand lies less than 1,000 feet below the surface. This zone is believed to mark the place where the upward-moving hydrocarbons have been oxidized by surface waters. The tarrification of the oil is caused chiefly by the addition of sulfur, derived from the sulfate-bearing surface waters. In places, this same reaction has produced deposits of sulfur. Author's summary condensed.

Pack, R. W., and English, W. A., 1915, Geology and oil prospects of Waltham, Priest, Bitterwater and Peachtree Valleys, central California: U.S. Geol. Survey Bull. 581-D, p. 119-160.

In several places in Bitterwater and Peachtree valleys, central California, oil impregnates the surficial sandy beds that lie in the San Andreas fault zone or that rest on the granite. The largest of these outcrops occurs at an asphalt quarry 2 miles west of Lonoak. The basal 25 to 50 feet of the upper Miocene here is a coarse arkosic sand or grit that is evidently derived from the underlying granite. The outcrops of this sand for a distance of about one-half mile are impregnated with tarry oil or asphalt, the amount contained varying from place to place. The oil sand is quarried from time to time and used in repairing the roads in the vicinity of King City. Most of the sand is medium coarse grained, and the material is used directly on the roads without the addition of more sand. The oil seeps in the region are closely associated with the diatomaceous shale of Miocene age, and none are known to occur where the shale has not been considerably developed. Authors' text condensed.

Page, B. M., 1945, Asphalt and bituminous sandstone deposits of part of the McKittrick district, Kern County, California: U.S. Geol. Survey Oil and Gas Inv. Prelim. Map 35, with text.

Large deposits of asphalt in the form of asphalt-bearing sandstone, asphaltbearing alluvium, oil seeps, and vein asphalt crop out near McKittrick, Kern County. The deposits occur in a number of rock types in the Monterey shale of Miocene age, the Etchegoin formation of Pliocene age, and the Tulare formation of Pliocene and early Pleistocene(?) age, and Recent alluvium. The rocks in the area are highly folded and faulted, and the asphalt deposits and a small producing oil field are associated with these structures. The total reserves in the area are about $\mathbf{1 5 . 7}$ million tons of asphalt-bearing rock.

Page, B. M., and Holmes, C. N., 1945, Bituminous sandstone deposits near Santa Cruz, Santa Cruz County, California: U.S. Geol. Survey Oil and Gas Inv. Prelim. Map 27, with text.

The bituminous sandstone deposits near Santa Cruz, Calif., lie 4 to 6 miles northwest of the city. They are concentrated in two areas; the southwesternmost is near the coast and is accessible both by highway and by a branch of 
the Southern Pacific Railroad, and the northwesternmost is in the low foothills of the Santa Cruz Mountains and is served only by unimproved roads. The bituminous sandstone deposits occur as normally bedded sandstone and as sandstone intrusions, both of which are generally more resistant to erosion than the enclosing sediments. Total reserves of asphalt-bearing sandstone are estimated to be about 1.6 million tons. Authors' text condensed.

Page, B. M., Williams, M. D., Henrickson, E. L., Holmes, C. N., and Mapel, W. J., 1944, Geology of the bituminous sandstone deposits near Edna, San Luis Obispo County, California: U.S. Geol. Survey Oil and Gas Inv. Prelim. Map 16, with text.

The asphalt occurs in the Pismo formation, of late Miocene and Pliocene age, which unconformably overlies the Monterey shale of Miocene age. The Monterey shale in the Edna area consists of tuffs, diatomaceous and siliceous shale, and chert. The Pismo formation consists of varied rock types including conglomerate, arkosic sandstone, diatomaceous sandstone, sandy and silty shale, diatomaceous shale, siliceous shale, and chert. The asphalt is irregularly distributed in lenticular, discontinuous beds of arkosic sandstone that range in thickness from a few feet to almost 300 feet. The largest deposits of asphalt-bearing sandstone crop out on the northeast flank of a northwesttrending syncline near Pismo Creek. The total reserves of asphalt-bearing sandstone equals about 280 million tons.

Parker, F. S., 1943, The Newport oil field, in Geologic formations and economic development of the oil and gas fields of California: California Div. Mines and Geology Bull. 118, p. 332.

The Newport field includes two small areas of barely commercial production - the Newport Beach area and the Mesa area. The whole area comprises about 7 square miles on Newport Mesa and the adjoining flats at the west end of Newport Bay, Orange County. The tar sands and seeps at the mouth of Newport Bay were known for many years. The Newport field is one of the few fields of the Los Angeles Basin that has been commercially unsuccessful, despite copious showings and strong surface evidence of oil. This lack of success is due mainly to the rapid incursion of water. Author's text condensed.

Peckham, S. F., 1882, Examination of the bituminous substances occurring in southern California, in Geology of California: Geol. Survey of California, Rept. of Progress and Synopsis of field work from 1860 to 1864, v. 2, App., p. 49-90, Sherman \& Co., Philadelphia, Pa.

This report, written in 1866, is one of the earliest reports on the California asphalts. It gives a general description of the geology of southern California and a detailed description of the various exposures of bitumen and their relative value. The section on chemical investigations details the early methods of distilling petroleum products from the crude asphalt.

Poth, E. J., Schulze, W. A., King, W. A., Thompson, W. C., Slagle, W. M., Floyd, W. W., and Bailey, J. R., 1930, An investigation of the bases in the kerosene distillate of California petroleum: Am. Chem. Soc. Jour., v. 52 , no. 3 , p. 1239-1250.

In the kerosene distillate, produced by the Union Oil Co. of California, from McKittrick asphalt-crude petroleum, with a total nitrogen content of 0.055 
percent, it was found that approximately 55 percent of the nitrogen compounds could be extracted with dilute sulfuric acid. In the higher boiling distillates in which the total nitrogen content is greater, the proportion of basic to inert nitrogen compounds decreased with an increase in the distillation temperature. Authors' text condensed.

Rogers, G. S., 1919, The Sunset-Midway oil field, California, Pt. II of Geochemical relations of the oil, gas, and water: U.S. Geol. Survey Prof. Paper 117, 103 p. [p. 29-32].

Petroleum consists of a complex mixture of many compounds made up chiefly of carbon and hydrogen. Some of these hydrocarbon compounds may also contain smaller quantities of oxygen, nitrogen, or sulfur, which have an important bearing on the properties of the oil. If paraffin or paraffin-bearing oil is digested with sulfur at moderate temperatures, it becomes black and heavy, and changes into a substance resembling solid asphalt. Similarly, if a light asphaltic oil is treated with sulfur it becomes darker and more viscous, finally becoming asphalt. Oxygen also exercises a profound effect on petroleum. When oil is exposed to air for a long time it becomes dark, heavy, and viscous and finally passes to asphalt. This change is due mainly to evaporation of the more volatile constituents, but also partly to oxidation. Author's text condensed.

Shea, G. B., and Higgins, R. V., 1948, Laboratory study of the hot-water process for separating hydrocarbons from surface deposits of bituminous sandstones near Edna, California: U.S. Bur. Mines Rept. Inv. 4246, 31 p.

This report presents the results of laboratory research in the adaptation of the hot-water separation process to the recovery of hydrocarbons from bituminous sandstones of the Edna deposits near San Luis Obispo, Calif. The hot-water process consists of three steps:

1. Heating and mixing the bituminous sandstone with water and enough alkaline reagent to form an alkaline pulp, in which the bitumen is displaced from the sand grains by the water. Efficient separation also depends on the occlusion of enough air to form an oil froth.

2. Separating the oil froth from the sand by submerging the pulp in hot water. The oil froth floats to the surface, and the sand grains, freed of the bitumen, sink to the bottom.

3. Removing the water, sand, and silt from the oil froth by dilution of the bitumen with a light oil and settling.

The soluble mineral salts in the Edna sandstones, mainly iron and calcium sulfates with some sodium and aluminum sulfates, must be removed by water washing.

Simm, C. N., 1964, How combustion drive projects are performing in California: World Oil, v. 159, no. 5, p. 151-154.

The combustion-drive process consists of injecting air to advance a narrow zone of high-temperature combustion from injection well to adjacent production wells. Combustion-drive projects were started at 27 localities in California in 1964. These locations are shown on a map, and individual projects are discussed in this report. Current production rate from combustion projects is 3,000-3,500 barrels per day, ranging from $14^{\circ}$ to $19^{\circ}$ gravity. Estimated capacity in 1965 is 10,000 barrels per day. Author's text condensed. 
Skinner, D. A., 1952, Chemical state of vanadium in Santa Maria Valley crude oil: Indus. and Eng. Chemistry, v. 44, no. 5, p. 1159-1165.

Chemical and physical techniques have demonstrated the presence of a vanadium-porphyrin complex in Santa Maria Valley crude oil. Absorption spectral data indicate that the complex is similar, if not identical, to the vanadium complex of mesoporphyrin IX dimethylester. The vanadium complex is not water soluble, but is soluble or dispersible in the crude oil. The complex possesses stability to electrical fields, and is also stable to heat treatment at $125^{\circ} \mathrm{C}$ in the presence of water, but breaks down or changes its form at or below $450^{\circ} \mathrm{C}$. It is not decomposed at $110^{\circ} \mathrm{C}$ in the presence of 85 percent orthophosphoric acid. The complex tends to be identified with the more asphaltic fractions of the crude. The biological origin of the complex is suggested by the similarity of its structure to that of complexes of metals and porphyrins found in contemporary mammals and plants. Author's conclusions condensed.

Smith, M. B., 1966, Asphalt and bituminous rock, in Mineral resources of California: California Div. Mines and Geology Bull. 191, p. 92-94.

The principal occurrences of asphalt and bituminous rock in California are at Edna, Casmalia, Sisquoc, Graciosa Ridge, Santa Cruz, McKittrick, Point Arena, and La Brea Creek. There are minor occurrences at Carpinteria and Rancho La Brea. Asphalt in California occurs at the surface where it is usually mixed with soil and in veinlike fracture fillings in rocks. Bituminous rocks, mainly sandstones or finer grained rocks impregnated with viscous asphaltic material, crop out in many places; in some places they extend to depths of several hundred feet, where they contain less viscous fluid and will yield oil to wells. Most deposits in the State are in sedimentary rocks of Miocene to Recent age. Estimated reserves are about 300 million barrels from only those deposits which have been carefully examined and worked in places. It is estimated that 1 billion barrels of oil-equivalent could be recovered from the higher grade bituminous shales of late Miocene and Pliocene age in the State, and that as much as 70 billion barrels of oilequivalent is present in widespread Miocene shales. Author's text condensed.

Stevens, J. B., 1943, McKittrick area of the McKittrick oil field, in Geologic formations and economic development of the oil and gas fields of California: California 'Div. Mines and Geology Bull. 118, p. 510-511.

The McKittrick area of the McKittrick oil field is in the foothills of the Temblor Range, along the southwest border of the San Joaquin Valley, Kern County. It is probably the oldest worked area in the San Joaquin Valley. Very early in the 1870 's the asphalt beds were opened, and the product was freighted by team to Bakersfield. On April 23, 1872, J. O. Lovejoy deeded 640 acres - now the heart of the McKittrick area - to the Buena Vista Petroleum Co. The first shallow development was to obtain oil to flux with the brittle surface asphalt in order to more satisfactorily meet trade requirements. The building of the Southern Pacific branch line in 1893 to Asphalto, 2 miles out of the present town of McKittrick, kept the asphalt business alive during the depression of 1893 and later stimulated the drilling of wells, as the advantage of fuel oil over coal in the development of power was quickly realized. Author's text condensed. 
Stipp, T. F., 1943, Simi oil field, in Geologic formations and economic development of the oil and gas fields of California: California Div. Mines and Geology Bull. 118, p. 417-423.

The Simi oil field is in the foothills of the Simi Valley, about 2 miles north of the town of Santa Susana in Ventura County. Though of minor importance with respect to quantity of oil produced, the Simi oil field is of interest because it is one of the few fields in California that yields oil from Eocene rocks. Active seepages of oil occur in Oil Canyon, where steeply dipping oilsaturated sands crop out. These seepages are from the Llajas conglomerate or from beds stratigraphically just above. Oil has accumualted in the sandstones and siltstones of the Llajas formation and, in the western part of the Simi field, in the sands at or near the base of the Sespe formation. The oil in the Sespe is of lower gravity than that in the underlying Llajas, and is apparently commercially unproductive. Author's text condensed.

Stock, Chester, 1930, Origin and physical features of the asphalt deposits, in Rancho La Brea - A record of Pleistocene life in California: Los Angeles Museum Pub. 1, p. 20-23.

The source rocks from which the petroleum is derived are the oil sands interstratified with the older shales and sandstones that underlie the Pleistocene beds in the region of Rancho La Brea. As determined by the geologic structure in the Salt Lake oil field, these older marine strata are deformed or folded. Presumably the exudation of the petroleum and penetration of the sedimentary strata, forming the tar pools and asphaltic material, occurred concurrently with the deposition of the Pleistocene alluvium, for asphalt deposits have been found at various levels throughout. At present the oil and gas reach the surface through fissures, pipes, or chimneys, and the oil forms small, generally shallow pools around the vents. Occasionally, a downward movement of the oil or tar can be discerned at the vents. A temporary release of gas pressure below permits the heavy oil to recede into the pipe or chimney from which it has extruded. This downward flow may carry remains of organisms, hardened lumps of asphalt, and other detrital material from the surface into the pipes. This action is of significance in suggesting a factor responsible for the movement of submerged animal remains in the larger Pleistocene outpours. During the Pleistocene, the outpouring of petroleum was probably much more extensive than it is now. The Pleistocene pools occupied the natural depressions of an irregular land surface and were, at times, many square feet in area. Excavations at Rancho La Brea have shown that the pools of fossiliferous asphalt ranged from relatively shallow accumulations to pools as much as 35 feet deep. Not all pools formed in natural depressions. In the past, sudden explosions of large quantities of gas and oil accompanied by sufficient force may have formed craterlike vents many feet in diameter. Small craterlike structures are now seen occasionally in the oil fields of California. Author's text condensed.

Swaze, R. O., 1943, Goleta gas field, in Geologic formations and economic development of the oil and gas fields of California: California Div. Mines and Geology Bull. 118, p. 384-385.

The Goleta gas field is located on the Pacific Ocean at the mouth of Goleta Slough, Santa Barbara County, about 4 miles east of the Elwood oil field. A tar seep exists on the beach on the southeastern flank of La Goleta anti- 
cline, where faults are evident in the surface rocks. The Monterey shales exposed along the axis and on the southern flank of the fold are coated with tar on their fractured surfaces. No showings of oil have been noted to date (1943) in the Vaqueros formation in any well drilled in the field. The upper part of the Sespe - in the one well drilled through this formation - contained numerous sands showing some oil saturation. However, production tests made on the best of these showings failed to develop commercial production. Author's text condensed.

Taff, J. A., 1908, Asphalt and bituminous rocks, in Mineral resources of the United States for 1907, Pt. II: U.S. Geol. Survey Mineral Resources of the United States, p. 723-730.

Extensive deposits of asphaltic shale and sandstone are found in California in and contiguous to the oil fields from the vicinity of Santa Cruz southeastward, generally parallel with the coastline. The bitumen permeates the porous sandy strata and exudes at the surface from highly bituminous oil-bearing deposits. The asphalt in this region appears to be a residue resulting from natural distillation at or near the surface. Brea, the natural plastic asphalt, is widely distributed in the California oil fields, where it forms at the ground surface, owing to the evaporation of the lighter oils from seeping crude petroleum. Author's text condensed.

Taliaferro, N. L., Hudson, F. S., and Craddock, W. N., 1924, The oil fields of Ventura County, California: Am. Assoc. Petroleum Geologists Bull., v. 8, no. 6 , p. $789-810$.

The unusually large oil seepages in Ventura County attracted the attention of oil operators at a very early date. As early as 1850 , oil from seepages was refined by the Mexicans for illuminating purposes in the early churches. Many large seepages, some of which cover many acres, occur along the faulted zone south of Ojai Valley and north of Santa Clara Valley. Although these seepages generally occur along faults, some may also be found in unfaulted areas where oil sands are exposed. At many places in the area east of Sespe Creek, oil oozes from both the Monterey shales and the sandstones interbedded with them. Seepages are rare in the major producing fields. Authors' text condensed.

VanderHoof, V. L., 1935, Seasonal bandings in an asphalt deposit at McKittrick [abs.]: Geol. Soc. America, 1934, Proc., p. 332.

A search for vertebrate remains in the asphalt deposits at McKittrick, Kern County, Calif., disclosed a series of alternating layers of alluvial detritus and tar. Almost the total thickness of this deposit, whose source seep is now extinct, is made up of these alternating layers. Associated with this series of layers are the remains of extinct mammals. The McKittrick seeps have had their origin in structural fissures that intersect the shallow oil sands of the McKittrick field. Many are still active and are similar to the banded seep containing fossils. The alternating bands represent a yearly recurrence of physical conditions that are influenced by climate. Winter cold so increases the viscosity of the tar that it congeals, whereas high summer temperatures render it fluid and able to flow downslope. Winter rains cause sheet wash, which blankets the previous summer's tar flow with alluvium. An older tar deposit, in which a skeleton of Bison antiquus was found at mid-level, is presumed to have accumulated in this manner. A sequence of 180 bands has 
been carefully measured and plotted, and efforts are now being made to correlate the resulting curves with tree-ring or glacial-varve chronologies. Author's text condensed.

Vander Leck, Lawrence, 1922, Memoranda on asphalt and bituminous sand deposits of California, in Eighteenth Report of the State Mineralogist: California Jour. Mines and Geology Bull., v. 18, no. 5, p. 228-230.

The principal deposits of bituminous shales and sands in California are in, or are closely associated with, Miocene diatomaceous shale. The California deposits are nothing more than sands and porous lenses of shale, saturated to varying degrees with liquid petroleum. These sands and shales, by reason of structural movements, have been uplifted into the zone of erosion, with the result that most of the lighter constituents have evaporated or run off, leaving a tarry residuum. This report lists and discusses the mining activity in each of the following districts: Point Arena, Marin County; Santa Cruz, Santa Clara County; Salinas Valley, San Luis Obispo, Santa Maria, and Santa Barbara Counties; and Coast Region from Gaviota Pass to Santa Barbara, Ojai Valley, Sunset, McKittrick, Santa Monica, Los Angeles County.

Vernon, J. W., and Slater, R. A., 1963, Submarine tar mounds, Santa Barbara County, California: Am. Assoc. Petroleum Geologists Bull., v. 47, no. 8, p. 1624-1627.

Tar mounds have been observed on the southern California sea floor at three localities: the Point Conception area, Coal Oil Point near Goleta, and off Carpinteria. Tar is most abundant near Point Conception, where a sheet of tar covers an area of one-fourth square mile, and forms a scarp at its seaward edge that is 10-12 feet high. East of the Point, mounds are as much as 100 feet across and 8 feet high. They are irregularly distributed along an easttrending zone of faulted anticlines exposed in the almost continuous shale outcrops on the ocean floor. At Coal Oil Point and Carpinteria the mounds are only a few inches high, and some are elongate along fractures in shallowdipping Monterey-type (Miocene) siliceous shale. Most of the mounds have roughly circular outlines; they rise abruptly from the sea floor and then slope upward gradually toward a vent at the central high point, resembling a miniature shield volcano. The mounds are accumulations of small discrete masses of tar, in the form of flows. Tar extrudes slowly from the vent and forms a tapered whiplike strand that floats but remains attached to the vent until it is several feet long. If seepage is slow enough, the attached "whips" become more dense than sea water and sink, to become part of the mound. If the "whip" is torn away by water agitation and tug of wave surge and currents, it floats to the surface and drifts, becoming increasingly dense with time. Failing to reach a shore before becoming denser than sea water, it sinks to the bottom and becomes incorporated in the sediment. Tar in the Point Conception area is extruded from upper Miocene-Pliocene siliceous and clay shales that are contiguous with those mapped on the Point. Authors' text condensed.

Waterfall, L. N., 1943, Santa Paula oil field, in Geologic formations and economic development of the oil and gas fields of California: California Div. Mines and Geology Bull. 118, p. 394.

Santa Paula field is the name applied to a group of small producing areas 
that extend along the south side of Sulphur Mountain, about 5 miles northwest of the town of Santa Paula, Ventura County. Because of the numerous active oil seeps and the outcrops of oil-impregnated sands along the south side of Sulphur Mountain, the area now known as the Santa Paula field was one of the first to attract the attention of oil prospectors. The first development of any consequence, however, was the drilling of an 80-foot-long tunnel into the south slope of Sulphur Mountain at an inclination which permitted the oil to flow by gravity into tanks at the mouth of the tunnel. The tunnel, completed by Leland Stanford in 1866, was the forerunner of about 45 such attempts to produce oil in this manner, the tunnels ranging up to 1,600 feet in length. Production of as much as 60 barrels per day is reported from some of these tunnels. The producing horizons of the Santa Paula field are the sandstones near the base of the Repetto formation (lower Pliocene) and the fractured shales at the top of the Modelo formation (upper Miocene). Author's text condensed.

Watts, W. L., 1894, The gas- and petroleum-yielding formations of the central valley of California: California State Mining Bur. Bull., no. 3, 100 p.

This is a detailed report on all the petroleum and asphalt deposits of the central valley of California and the neighboring foothills. The principal showing of Tertiary hydrocarbons on the west side of the San Joaquin Valley is found in what appears to be the lowest Tertiary unit. These lower Tertiary strata consist of a porous, siliceous shale that yields a heavy tarlike oil. Seepages of tarlike oil exude from Tertiary sandstone at the Krayenhagen Ranch, at Tar Cañon, and at Asphalto, and bituminous sands, which are probably of this age, are found on the banks of the Kern River on the east side of the San Joaquin Valley. At many places in the foothills along the west side of the San Joaquin Valley, bituminous Tertiary sandstones are exposed.

Watts, W. L., 1896, Oil and gas yielding formations of Los Angeles, Ventura, and Santa Barbara Counties: California State Mining Bur. Bull., no. 11, p. 48-52.

The following oil fields are described: In Los Angeles County, the Los Angeles City and Puente oil fields; in Ventura County, the Sespe district and Santa Paula district; in Santa Barbara County, the Summerland oil field and the petroleum-yielding formations in the southeast corner of the county. Detailed descriptions of individual deposits are given, as well as a résumé of the refining methods used in the area to 1896.

Watts, W. L., 1900, Oil and gas yielding formations of California: California State Mining Bur. Bull. 19, 236 p. [p. 225-227].

Petroleum, in the form of natural gas, oil, and asphaltum, is found at various places in the Coast Ranges and in the foothills of the Sierra Nevada in Kern County. The geological formations yielding petroleum in California range in age from Lower Cretaceous to Quaternary. Historical sketches of the following oil fields are given: The Summerland oil field, Santa Barbara County; Coalinga, in Fresno County; Kern River, Sunset, and McKittrick districts, in Kern County; Puente Hills, in Orange and Los Angeles Counties and in the city of Los Angeles. Only the asphalt deposits of the McKittrick district are described in detail, as follows: The asphaltum deposits at Asphalto are found under two conditions - as superficial deposits of impure asphaltum, 
and as veins of asphaltum in the Miocene formations. The superficial deposits have been formed by exudation of heavy oil; they originally covered many acres and were from 1 to 12 feet thick. This asphaltum varies greatly in quality, from a dull-black compact asphaltum to an impure asphaltum interbedded with drift. The principal asphaltum mines are $11 / 2$ miles southeast of McKittrick and occur as irregular veins and intrusive masses in the middle Miocene rocks. Author's text condensed.

Weber, A. H., 1887, Petroleum and asphaltum in portions of northern California: California Jour. Mines and Geology, v. 7, p. 200-202.

At Point Arena in Mendocino County, bituminous sandstone was being quarried in 1887 for use as paving material. Two ledges of bituminous sandstone were exposed in the quarry. The lower ledge, 9 feet thick, was brownish black; it crumbled between the fingers easily and, on ignition, showed 6.8 percent volatile matter. The residue consisted of coarse quartz sand. The upper ledge was very different. It was a black sticky pliable mass, which was coarse grained, but had reunited under pressure. On ignition, it showed 11.2 percent volatile matter. The residue consisted of quartz grains stained by iron oxide.

Whitney, J. D., 1865, Geology of California - Report of progress and synopsis of fieldwork from 1860 to 1864: California Geol. Survey, v. 1, Sherman \& Co., Philadelphia, Pa.

This report is one of the first written accounts to mention the asphalt deposits of California. In 1865 no commercial use was being made of the asphalts, other than as roofing and paving material in San Francisco. The Hills Ranch deposit along the beach west of Santa Barbara is described in detail.

Williams, M. D., and Holmes, C. N., 1945, Geology of oil-impregnated rock near Casmalia, Santa Barbara County, California: U.S. Geol. Survey Oil and Gas Inv. Prelim. Map 34, with text.

A deposit of asphalt-bearing diatomaceous mudstone is exposed about 4 miles north of Casmalia, Santa Barbara County, at the N.T.U. open-pit mine, now abandoned. Similar beds crop out half a mile northeast of the N.T.U. mine and in the Schumann area, 3 miles to the southeast. The asphalt-bearing beds may be continuous throughout these areas. The asphalt impregnates northeastward-dipping beds of diatomaceous mudstone in the upper part of the Sisquoc formation of Miocene and Pliocene age. Although the asphaltbearing beds are as much as 20 feet thick at the N.T.U. mine, the extent of downdip impregnation is not known. The estimated reserves at the mine are 100,000 tons of asphalt-bearing rock.

Wilson, T. A., and Mero, J. L., 1966, Economic deposits of the California offshore area, in Geology of northern California: California Div. Mines and Geology Bull. 190, p. 347.

Unusual occurrences of submarine tar deposits have been observed in shallow water on the sea floor off the coast of southern California, in at least three localities - the Point Conception area, at Coal Oil Point near Goleta, and off Carpinteria. Scuba-diving geologists doing underwater mapping for oil companies first discovered these deposits in the mid-1950's. Tar is most abundant in the Point Conception area, where a sheet of the material covers 
at least one-fourth of a square mile and forms a 10- to 12-foot scarp at its seaward edge. East of the Point, individual deposits as much as 100 feet in diameter and 8 feet in height have been reported. The deposits are irregularly distributed along the east-trending zone of faulted anticlines exposed in the shale outcrops on the ocean floor. Most of the tar occurs as roughly circular mounds that resemble miniature volcanoes with the sides sloping gradually upward toward a vent at a central high point. It is suggested that the present deposits must have developed since the last major rise in sea level, about 9,000 years ago. Authors' text condensed.

Woodring, W. P., and Bramlette, M. N., 1950, Geology and paleontology of the Santa Maria district, California: U.S. Geol. Survey Prof. Paper 222, 185 p. [p. 124-125].

During 1942-45 discoveries of heavy oil were made in the Santa Maria district. These discoveries were thought by the authors to be subcommercial because the oil was too heavy to be produced profitably.

\section{COLORADO}

Subject Index

Basins

Denver

Stewart, W. A., 1953

Piceance

Ball Associates, Ltd., 1965

Duncan, D. C., and Belser, Carl, 1950

Sand Wash

Mesozoic

Ball Associates, Ltd., 1965

Brainerd, A. E., Van Tuyl, F. M., and O'Boyle, C. C., 1955

DeFord, R. K., 1929

Fenneman, N. M., 1903

Fenneman, N. M., 1905

Grout, F. F., Worcester, P. G., and Henderson, Junius, 1913

Hills, R. C., 1900

Lakes, Arthur, 1902

Larrabee, D. M., and others, 1947

Lee, H. A., 1899

Sears, J. D., 1925

Stewart, W. A., 1953

Van Tuyl, F. M., and others, 1938

Wise, R. A., 1952

Oil associated with crystalline rocks

Irwin, J. S., 1926

Van Tuyl, F. M., and McLaren, R. L., 1932

Oil seepages

Brainerd, A. E., Van Tuyl, F. M., and O'Boyle, C. C., 1955

DeFord, R. K., 1929

Fenneman, N. M., 1903

Fenneman, N. M., 1905

Irwin, J. S., 1926 
Oil seepages - Continued

Larrabee, D. M., and others, 1947

Van Tuyl, F. M., and others, 1938

Paleozoic

Wise, R. A., 1952

Bass, N. W., and Northrop, S. A., 1963

Donnell, J. R., 1958

Wise, R. A., 1952

Resources

Barb, C. F., and Ball, J. O., 1944

Structure

Sears, J. D., 1925

Tertiary

Aurand, H. A., 1920

Beekley, A. L., 1915

Duncan, D. C., and Belser, Carl, 1950

Eldridge, G. H., 1901

Larrabee, D. M., and others, 1947

Sears, J. D., 1925

Vein deposits

Vine, J. D., 1957

Aurand, H. A., 1920

Barb, C. F., and Ball, J. O., 1944

Bass, N. W., and Northrop, S. A., 1963

Beekley, A. L., 1915

Eldridge, G. H., 1901

Lee, H. A., 1899

Vine, J. D., 1957

\section{Author List}

Aurand, H. A., 1920, Mineral deposits of the Western Slope: Colorado Geol. Survey Bull. 22, 78 p., 2 maps.

The natural hydrocarbons of Colorado, as well as those of eastern Utah, appear to be confined to the Tertiary formations. In these districts the various divisions of the Eocene are noted for the number, size, and variety of their asphalt veins. Many of the asphaltic veins near the Colorado-Utah line occur in fissures in the Green River formation and in the overlying Bridger and Uinta formations. The bitumens of the Green River shales may have been the source of the asphalt. The veins can be traced for as much as 2 miles on the surface, and they are known to extend to a depth of 100 feet. A deposit of asphaltite is located on the east side of Sherman Creek, near the north edge of Middle Park. The veins occur as fissure fillings in the clays, sandstones, and conglomerates of the Middle Park formation, which is probably the equivalent of the Denver formation. This deposit is comparatively isolated, as the closest known occurrence of asphaltite is $\mathbf{1 5 0}$ miles away, on the ColoradoUtah line. Author's text condensed.

Ball Associates, Ltd., compiler, 1965, Colorado, in Surface and shallow oilimpregnated rocks and shallow oil fields in the United States: U.S. Bur. Mines Mon. 12, p. 88-104 [p. 90-104]. 
The largest petroleum-impregnated outcrops known in Colorado are in Moffat, Rio Blanco, and Garfield Counties. Geologically, these outcrops are within, or are on the flanks of, the Piceance (eastern Uinta) and Sand Wash (southern Green River) basins. None is of present commercial importance. Other minor accumulations are widely scattered, with a notable concentration along the foothills of the Front Range of the Rocky Mountains. Author's text condensed.

Barb, C. F., and Ball, J. O., 1944, Hydrocarbons of the Uinta Basin of Utah and Colorado - Review of geology and fieldwork by C. F. Barb; Survey of bitumen analyses and extraction methods by J. O. Ball: Colorado School Mines Quart., v. 39, no. 1, 115 p., illus. incl. geol. sketch maps.

There are many deposits of bituminous sands and numerous oil seeps throughout the Uinta Basin in Utah and Colorado. The deposit largest in tonnage is the Sunnyside asphalt mine, about 7 miles up the eanyon from the Sunnyside coal mines. It is a cliff of asphaltic sand (Wasatch formation) about 1,200 feet high and several miles long. Another deposit occurs at Asphalt Ridge about 3 miles west of Vernal. This deposit is estimated to contain 2-3 billion barrels of bitumen that can be mined by open-pit and underground mining methods. It is $12-15$ miles long. These rocks crop out again in Whiterocks Canyon, 25 miles to the northwest. Gilsonite, probably the most important hydrocarbon in the Uinta Basin, occurs as veins in the Green River and Wasatch formations. The largest deposits occur as veins at the east end of the basin (near Watson and north of White River), although other smaller veins are known. An ozokerite deposit occurs near Soldier's Summit, on the west edge of the Wasatch Basin. The ozokerite, a mineral wax similar to the paraffin wax, occurs as vertical veins in the Wasatch formation, apparently filling fault fissures. The approximate locations of the hydrocarbon deposits are shown on the map which accompanies this report.

Bass, N. W., and Northrop, S. A., 1963, Geology of the Glenwood Springs quadrangle and vicinity, northwestern Colorado: U.S. Geol. Survey Bull. 1142-J, 74 p. [p. 49].

The lower part of the South Canyon Creek Member of the Maroon Formation (Pennsylvanian and Permian) consists of fine- to medium-grained dolomite and dolomitic limestone. It commonly contains a few veinlets and irregular nodules of milk-white or light-gray chert and vugs and geodes, most of which are less than $1 \frac{1}{2}$ inches in diameter and many of which contain jet-black brittle lustrous asphalt. The upper part of the member consists of thinly laminated limestone, whose wavy structure and alternating light and dark bands suggest an algal origin. Where recrystallization has occurred, laminae of finely crystalline calcite are bounded by very thin seams of asphalt. The Weber Sandstone Tongue of the Maroon Formation is impregnated with a black organic substance reported to be a residue of petroleum. The Weber Sandstone is the principal oil reservoir in the Rangely oil field, 65 miles to the northwest. Authors' text condensed.

Beekley, A. L. 1915, Geology and coal resources of North Park, Colorado: U.S. Geol. Survey Bull. 596, 121 p. [p. 117-118].

The gilsonite mine near Willow Creek Pass is in secs. 15 and 22, T. 4 N., R. 77 W., about 4 miles southeast of Willow Creek Pass. The gilsonite bears a 
general resemblance to a glossy coal. It is very brittle, breaks with somewhat conchoidal fracture in one direction and along smooth rectangular cleavage planes in the other, and is a very lustrous, satiny black. The gilsonite occurs as a vein in a sandy clay that contains lenses of friable sandstone and boulders or nodules of soft sandy clay. The vein has been mined for several hundred feet and ranges in thickness from a few inches to 8 feet. The gilsonite is believed to occur in the lower part of the Coalmont formation. Author's text condensed.

Brainerd, A. E., Van Tuyl, F. M., and O'Boyle, C. C., 1955, Oil and gas in eastern Colorado, in Geology of the Front Range foothills west of Denver-Deer Creek to Ralston Creek, Jefferson County, Colorado, Rocky Mtn. Assoc. Geologists Field Conf. Guidebook, 1955: p. 39-49.

Small amounts of oil were produced as early as 1862 from shallow wells near an oil seepage on Oil Creek about 6 miles north of Canon City. Commercial amounts of oil were discovered near Boulder and Fort Collins in 1902 and 1923, respectively. The discovery of the Greasewood oil pool in Weld County in 1930 furnished convincing proof that important accumulations of oil and gas were present in eastern Colorado. Since 1950 the productive belt has been extended southwest from Logan County through Morgan and parts of Washington and Adams Counties. Authors' text condensed.

DeFord, R. K., 1929, Surface structure, Florence oil field, Fremont County, Colorado, in Structure of typical American oil fields: Am. Assoc. Petroleum Geologists, v. 2, p. 75-92, 4 figs., 1 pl.

The oil-producing district in the vicinity of Canon City and Florence is one of the oldest in the United States. The first wells were sunk near a seep on the bank of Oil Creek, 9 miles northwest of the town of Florence and 6 miles northeast of Canon City. The oil occurs in joints and fissures of the Pierre shale. The sandy zones, thin sand beds, numerous concretionary beds, and possibly even the buried Tepee Buttes may be reservoirs for this disseminated supply. Author's text condensed.

Donnell, J. R., 1958, The Weber sandstone in the White River uplift, in Rocky Mtn. Assoc. Geologists Symposium on Pennsylvanian rocks of Colorado and adjacent areas: Denver, Colo., p. 95-98.

Much of the Weber sandstone is saturated with dead oil throughout its outcrop in this area. This sandstone is the oil-producing formation in Rangely, Thornburg, and several other fields in northwestern Colorado.

Duncan, D. C., and Belser, Carl, 1950, Geology and oil-shale resources of the eastern part of the Piceance Creek basin, Rio Blanco and Garfield Counties, Colorado: U.S. Geol. Survey Oil and Gas Inv. Map OM-119, structure map with sections and text.

Rocks in the Piceance Creek basin that yield oil include marlstone, organic shale, thin layers of altered tuff in the oil shale, beds of asphalt-saturated sandstone, and small amounts of asphaltlike hydrocarbons along the fault and joint planes. Most of the organic matter is in the shale and marlstone in a solid form as kerogen, which converts to heavy oil with destructive distillation. Perhaps the free asphalt or heavy oil of the sandstone and altered tuff beds was derived from the oil shale. Authors' text condensed. 
Eldridge, G. H., 1901, Colorado in The asphalt and bituminous rock deposits of the United States: U.S. Geol. Survey Ann. Rept., 22d, pt. 1, maps, p. 209-452 [p. 228-229].

Bitumen occurs in the Middle Park formation of Middle Park, Colo., largely a terrane of eruptive material and a correlative of the Denver formation of the plains - a formation that is, for the present, termed "post-Laramie," without assignment to Cretaceous or Tertiary. In the northern part of Middle Park, the bitumen occurs as an asphalt, resembling gilsonite, that occupies an irregular fissure or series of fissures in the clays, sandstones, and conglomerates. The occurrence is, so far as known, limited to the immediate region in which it is found. The nearest asphalt is the gilsonite, 150 miles away, along the Colorado-Utah line. [The veins of gilsonite along Colorado's west border are referred to in the section on Utah.] Author's text condensed.

Fenneman, N. M., 1903, The Boulder, Colorado, oil field: U.S. Geol. Survey Bull. 213-H, p. 322-332.

Oil seeps occur on the north bank of the Little Thompson River, 17 miles north of Boulder and several miles east of the foothills. There, at the base of the heavy sandstone strata in the Pierre shale, a seepage of oil has been known since about 1860. Similar, but less well known seeps are reported to occur 5-10 miles north of Boulder. The source of the oil is not yet determined within narrow limits. Much of the Pierre is black with disseminated carbonaceous matter. The Niobrara formation below is similarly bituminous, yielding a strong odor from its more fossiliferous beds. The same is true of the Benton shale, which is characteristically dark and whose bituminous odor is at least as well marked as that of the Niobrara. The Dakota sandstone bears oil in Wyoming, and asphalt oozes from its cracks at various places from Wyoming to southwestern Colorado. Even the Morrison formation bed contains some oil, as seen near the Florence field.

Fenneman, N. M., 1905, Geology of the Boulder district, Colorado: U.S. Geol. Survey Bull. 265, 101 p. [p. 7.6-98].

The development of oil and gas in the Boulder area dates from about 1901. The evidence that oil was present consisted of the strong bituminous odor of the Benton and Niobrara limestones and shales. Surface indications, consisting of oil seepages and springs, also occur in the area. Some of the springs which issue from the Fountain red beds are abundantly coated with oily matter, but in none of these was the odor of petroleum detected. The wellknown oil spring on the bank of the Little Thompson River, 17 miles north of Boulder, issues from the heavy sandstone member of the Pierre shale, called in this report the Hygiene sandstone. Author's text condensed.

Grout, F. F., Worcester, P. G., and Henderson, Junius, 1913, Reconnaissance of the geology of the Rabbit Ears region, Routt, Grand, and Jackson Counties: Colorado Geol. Survey Bull. 5, pt. 1, map, p. 1-57 [p. 57].

Gilsonite or some related hydrocarbon, probably ozocerite, occurs locally in the Dakota sandstone. The most notable occurrence is about 5 miles north of Rabbit Ears, where a layer of the Dakota sandstone is sufficiently charged with hydrocarbons to give it a black or dark-brown appearance. The extent of the layer is probably small, as the Dakota is here faulted out as a block and 
is not continuous with the hogbacks north and south of it. Authors' text condensed.

Hills, R. C., 1900, Description of the Walsenburg quadrangle [Colorado]: U.S. Geol. Survey Geol. Atlas, Folio 68, 6 p., 6 maps.

About 2 miles north of the Huerfano River, near the west boundary of the Walsenburg quadrangle, there are two small dikes of dark-colored basalt. At the point where they cut through the bituminous material of the Apishapa (Cretaceous) formation, the cavities in the dike rock afford sufficient crude oil to soil the hand when the rock is freshly broken. The supposition is that the oil has resulted from the action of the lava at a high temperature on the adjacent bituminous matter. Author's text condensed.

Irwin, J. S., 1926, Faulting in the Rocky Mountain region: Am. Assoc. Petroleum Geologists Bull., v. 10, no. 2, p. 105-129 [p. 111-113], 7 figs.

An active oil seep in Gold Run Canyon, 11/2 miles north of Golden, Colo., is evidently caused by the structural relationships induced by faulting. The seep is unique in that the oil emerges from Precambrian gneiss. Apparently, the oil originates in the upturned Cretaceous beds that form the footwall of the thrust fault. It migrates upward across the fault plane and escapes to the surface through joints in the gneiss in the hanging wall. At times, enough oil collects in small depressions and on the surface of puddles of water in the generally dry creek bed that small bottles can be filled with it. Plastic asphaltic material occurs in places, and masses of pebbles and boulders in a matrix of dry asphalt resembling the material of bitulithic pavement abound. Author's text condensed.

Lakes, Arthur, 1902, Oil in Colorado: Mines and Minerals, v. 22, p. 256-257.

At Florence, near Canon City, Colo., oil is found in a shallow synclinal fold or basin in the marine shales of the Cretaceous Montana Group. The fold is in part overlain by the coal-bearing rocks of the Laramie Cretaceous. The exact location of the oil appears to be in a sandy zone near the top of the Fort Pierre division of the Montana group. A much lower oil horizon is found in the foothills on Oil Creek, 8 miles north of Canon City in the Upper Jurassic rocks. The first discovery of oil in Colorado was made here in the 1820's. The oil was heavy and dark and was mined in a crude way, but the deposit has not been opened up for many years. The ultimate source of the oil found in the Florence Basin may have been this Jurassic horizon or even from still lower zones. The sandstones of the Dakota group (Cretaceous) on Turkey Creek about 20 miles west of Denver are heavily impregnated with brown oil and tarry matter. This oil sand is in an intermediate zone between that in the Montana group at Florence and that in the Jurassic on Oil Creek. A similar occurrence 6 miles north of Golden at the same horizon leads to the conclusion that the Dakota group may some day prove to be an important oil zone in Colorado. In Boulder County test wells exploring for oil have been sunk in the Montana Cretaceous at about the same horizon as at Florence. A flow of oil has been obtained from about 2,400 feet. Author's text condensed.

Larrabee, D. M., Clabaugh, S. E., Griffitts, W. R., Fischer, E. C., Fox, E. L., Bryson, R. P., Weeks, R. A., Varnes, D. J., and Rolnick, L. S., compilers, 1947, Map showing construction materials and nonmetallic mineral re- 
sources of Colorado: U.S. Geol. Survey Missouri Basin Studies Map 10, with text.

Asphalt and other bitumens, in some places used as a local source for road surfacing or for construction purposes, have been reported in Fremont, Grand, Garfield, Moffat, and Rio Blanco Counties. They are said to occur as layers between beds, as veins in sandstone and shale, and as seeps in sandstones of Tertiary, Cretaceous, and Jurassic age. Bitumens have been mined in Middle Park, Park County, and near Rio Blanco in Rio Blanco County. Production data are not available but the output probably has been small. Authors' text.

Lee, H. A., 1899, The asphalt deposits of Middle Park, Colorado: Eng. and Mining Jour., v. 67, no. 16, p. 468.

Interest has been aroused by the discovery of asphalt in Middle Park, Grand County, Colo., during 1898. The deposits consist of small fissures in the Cretaceous rocks extending along the 106th meridian north of lat $40^{\circ}$ as described by Hayden. These fissures seem to cut the formation which dips to the west and seem to be the eastern extremity of the Cretaceous sandstones of Utah and western Colorado. The veins vary in size from a mere seam to disconnected pockets 4-6 feet wide. The main vein pinches out about 50 feet below the surface. The veins show strong volcanic action - the formation is heavily stained for considerable distance on both sides of the streak, and the action of gasses emitted is noticeable for a distance of 50-100 feet. The product is of two kinds. One kind is a hard brownish substance that has a smooth fracture, though tough and granular in its structure, and that is readily fusible over flame, but it will not melt of itself. This kind, which seems to have been subjected to a very high temperature, fills the veins. The other kind of product occurs as swells or pockets in the vein, and seems to be a secondary flow; it is very brittle and has a conchoidal fracture very similar to the uintahite or gilsonite of Utah. In the basin east of these deposits and in the area west of Grand Lake, there is an overflow of brea, but its source has not been found. Author's text condensed.

Sears, J. D., 1925, Geology and oil and gas prospects of part of Moffat County, Colorado, and southern Sweetwater County, Wyoming: U.S. Geol. Survey Bull. 751-G, p. 269-319 [p. 307-319].

Oil-saturated sand of the Browns Park formation is seen at two localities. For several hundred feet along the bottom of a gulch in sec. 6, T. 9 N., R. $100 \mathrm{~W}$, the sandy matrix of the basal conglomerate is heavily saturated with oil. There, the Browns Park probably rests upon the upturned edge of the Park City formation, in which the oil may have originated. A second and smaller area of saturation is just north of the Craig-Vernal road, half a mile east of Elk Springs, in sec. 30, T. 5 N., R. 98 W., where the Browns Park rests unconformably upon the upper part of the Mancos shale. In sec. 9, T. 12 N., R. 98 W., Wyoming, the Green River beds are dragged sharply upward on the north side of the fault near Shell Point. A thin sandstone in the Green River shale is slightly saturated with oil for a few feet along the outcrop; the oil may have come from the oil shale of the Green River or may have risen in the fault from some older rocks. Near Marshalls Spring in the SW $1 / 4$ sec. 24, T. 9 N., R. 100 W., oil is found in the joints and between the laminae of the blocky shale that forms the base of the Mancos shale, and a 
thin sandstone in this shale is saturated with oil. The sandy matrix of the conglomerate in the lower part of the Dakota sandstone is heavily saturated with oil for several hundred yards along the outcrop in sec. 23, T. 9 N., R. $100 \mathrm{~W}$. Associated faults may have permitted migration of the oil from the Park City or some other underlying formation, or the oil may have originated in the basal shales of the Mancos, which everywhere contain abundant fish scales. In the $\mathrm{SE}^{1} / 4$ sec. 6, T. 9 N., R. 100 W., a 10-foot-thick sandstone in the upper part of the Nugget sandstone shows heavy oil saturation for several hundred yards along its outcrop. A small vein of elaterite is exposed in the upper part of the Mancos shale near the northwest end of the Beaver Creek anticline, in the NE1/4 sec. 34 , T. 5 N., R. 90 W. The elaterite is a natural bitumen thought to have been formed as residue from petroleum escaping through a fault. Author's text condensed.

Stewart, W. A., 1953, Structure and oil possibilities of the west flank of the Denver Basin, north-central Colorado: Colorado School Mines unpub. D.S. thesis 777,121 p. [p. 104-107], 20 figs., 14 pls.

There are at least nine known occurrences of bituminous material in the foothills belt between Ralston Reservoir and Dutch Creek. They consist of live oil seeps, dead oil residues, asphaltic sandstones, solid brittle bitumens, and shows in both oil and water wells. These occurrences are shown on an accompanying map. All these occurrences are located in the hanging wall of the Golden fault. The source of many of these hydrocarbons could be the 9,000-foot section of marine limestones and shales of the Benton, Niobrara, and Pierre formations in the footwall of the fault. Trap possibilities are almost negligible in the upthrown block, and commercial accumulations, if present, are believed to be on the downthrown side of the fault. Author's text condensed.

Van Tuyl, F. M., Johnson, J. H., Waldschmidt, W. A., Boyd, James, and Parker, B. H., 1938, Guide to the geology of the Golden area, Colorado: Colorado School Mines Quart., v. 33, no. 3, 32 p. [p. 30], 1 pl., geol. map, 10 figs.

Several oil seeps occur in this area. Two of these are northwest of Golden, and one is near Morrison. At the Morrison locality several hundred tons of bituminous sand occur in the upper part of the Dakota sandstone. Petroleum has never been produced in commercial amounts in this area, but the seepages, together with the knowledge that marine sedimentary rocks undoubtedly underlie the Precambrian rocks west of the fault trace in the vicinity of Golden, lend support to the view that some oil may be impounded. Authors' text condensed.

Van Tuyl, F. M., and McLaren, R. L., 1932, Occurrence of oil in crystalline rocks in Colorado: Am. Assoc. Petroleum Geologists Bull., v. 16, no. 8, p. 769-776.

The occurrence of oil in crystalline rocks in Colorado includes (1) seepages of oil in Precambrian gneiss near Golden, and (2) oil in amygdaloidal cavities of basalt dikes on both flanks of the Rocky Mountains in the southern part of Colorado. The conclusion is reached that the oil seepage in the gneiss is derived from sedimentary rocks, presumably of Dakota age, faulted under the Precambrian crystalline rocks during the Laramide revolution. The oil of 
the amygdaloidal cavities of basalt is ascribed to the natural distillation of organic matter of kerogen-bearing shales penetrated by the intrusion. Authors' abstract.

Vine, J. D., 1957, Grahamite deposits near Willow Creek Pass, Grand County, Colorado, in Rocky Mtn. Assoc. Geologists Guide Book to the geology of North and Middle Parks basin, Colorado, 1957: p. 125.

A deposit of asphaltic material, probably grahamite (but which has also been called gilsonite), occurs near the Continental Divide between North Park and Middle Park, Grand County, Colo. Good samples of asphaltic rock are to be found on dumps and in prospect pits. The deposits are at an altitude of about 9,500 feet, and the slopes are heavily timbered; consequently, few rock exposures can be seen aside from the old workings. According to Eldridge, the asphaltic material occurs in steeply pitching veins or fissures up to 6 feet thick within a north- or northwest-trending fracture zone. The enclosing beds are described as alternating clay, conglomerate, and sandstone in the Middle Park formation of Late Cretaceous and Paleocene age. The mines were probably in operation at the time Eldridge made his examination in about 1899. The origin of the grahamite near Willow Creek is unknown. The grahamite is probably a petroleum derivative, but the possibility also exists that it was derived from coal. Author's text condensed.

Wise, R. A., 1952, Eastern Front Range and foothills geology of central Jefferson County, north-central Colorado: Colorado School Mines, unpub. D.S. thesis $741,192 \mathrm{p}$.

A bituminous seep occurs in Red Rocks Park, immediately west of the main parking lot. Gas and oil occurrences in a water well drilled south of the park and west of Morrison, and bitumen occurring in the basal limestones of the Lykins formation in Glennon Canyon, about $1 \frac{1}{2}$ miles south of Morrison, are described. The oil seep at the dip slope of the Dakota hogback south of Turkey Creek has been described by several writers, perhaps the earliest of whom was Hayden (1874). Location of these seeps, approximately along a somewhat arcuate alinement, suggests structural kinship. Oil from the three seep locations appears to be the same. The evidence cited supports the contention of a structural trend, faulting perhaps, connecting the three seepage points and along which the oil has been able to migrate from its source. Author's text condensed.

\section{ILLINOIS}

\section{Anthor List}

Ball Associates, Ltd., compiler, 1965, Illinois, in Surface and shallow oilimpregnated rocks and shallow oil fields in the United States: U.S. Bur. Mines Mon. 12, p. 104-108 [p. 104].

In and around Chicago, quarries in the Silurian limestones have exposed many small patches of impregnation - variously referred to as asphalt, tar, albertite, and tarry oil - in vugs, pores, and seams. The relationship of these accumulations to Silurian reef structure and lithology has been recognized and studied extensively, but the hydrocarbon content apparently adds no value to the rock and little has been published about it. Author's text condensed. 


\section{INDIANA}

Author List

Fuller, M. L., 1903, Asphalt, oil and gas in southwestern Indiana: U.S. Geol. Survey Bull. 213-H, p. 333-335.

During the drilling of a well by the Interstate Gas \& Oil Co. at Princeton, in 1902, a bed of asphalt several feet thick was found, somewhat more than 100 feet below the Petersburg coal, that has been mined three-quarters of a mile west of the well. A similar bed is reported to have been penetrated in the old Hall well on the southwest outskirts of Princeton, about 1 mile south of the new well. In a mine west of the well, a black substance - known as liquid asphalt - has seeped into the bottom of the mine at a depth of 450 feet to such an extent that some of the rooms have had to be closed and abandoned. This substance is said to enter through a nearly vertical "break" filled with clay. Author's text condensed.

\section{KANSAS}

Subject Index

Regional

Ball Associates, Ltd., 1965

Jewett, J. M., 1940

Recovery Methods

Enright, R. J., 1964

Goebel, E. D., 1966

Resources

Ball Associates, Ltd., 1965

\section{Author List}

Ball Associates, Ltd., compiler, 1965, Kansas, in Surface and shallow oilimpregnated rocks and shallow oil fields in the United States: U.S. Bureau Mines Mon. 12, p. 112-125 [p. 114].

Miami, Linn, Bourbon, and Labette Counties, in eastern and southeastern Kansas, contain the known surface bituminous rocks and shallow oil fields. Additional shallow oil reserves are known in Douglas, Franklin, and Montgomery Counties. The rocks containing the bitumen and oil are Pennsylvanian sandstone and limestone of the Des Moines and Missouri Series. The average reported thickness of bituminous rock in eastern Kansas is about 4 feet. A notable exception, the Pleasanton area deposit, has a maximum thickness of 16 feet and an average thickness of 12 feet. The bitumen content at Pleasanton and at Mantey varies from 2.8 to 5.5 percent. Author's summary condensed.

Enright, R. J., 1964, Heavy-oil recovery experiments spread in east Kansas: Oil and Gas Jour., v. 62, no. 25, p. 112-114.

Projects using unconventional means to try to produce the low-gravity oil deposits in eastern Kansas are planned or are underway. Fire flooding, steam projects, "pusher" floods, and flue-gas-injection operations are all either now operating or soon to start in the heavy-oil campaign. Whether projects now 
going into operation will find a way to produce the region's heavy-oil sands is not yet apparent.

Goebel, E. D., 1966, Thermal recovery projects are increasing in Kansas and Missouri: World Oil, v. 162, no. 4, p. 78-80.

Both the major and the smaller, independent oil companies are leasing, core drilling and experimenting in the 11-county low-gravity-crude area of eastern Kansas and western Missouri. Thermal projects in water floods are not now prorated in Kansas, and, as a result, the oil companies are applying heat to reservoirs through a variety of methods. Target of the most recent work has been the Cherokee and Marmaton Group rocks (Bartlesville, Bluejacket, Squirrel, and Peru sands). The Cherokee Group crops out in southeastern. Kansas. There, asphaltic and tar sands have been quarried and mined in the past from Pleasanton and Kansas City rocks. In the easternmost counties in Kansas, some of the older fields have a history of a decrease in oil gravity with an increase in age of the field. Some fields have recorded drops in gravity of as much as $3^{\circ}$ over a 10-year period. Migration and accumulation were affected by many earth movements, and there was creation of fissures and joints in the overlying rocks; locally, gas escaped from these fissures, resulting in these low-gravity-crude deposits. Author's text condensed.

Jewett, J. M., 1940, Asphalt rock in eastern Kansas: Kansas Geol. Survey Bull. 29, 33 p., with illus., index, and geol. maps.

The known asphalt rocks in eastern Kansas are Pennsylvanian in age. They are the porous limestones and sandstones of the Marmaton group, the Bourbon formation, and the Bronson group. They crop out in a band, 15-40 miles wide, from Miami and Linn Counties southward to Montgomery and Labette Counties. Linn County is the only locality in Kansas from which asphalt was being produced in 1940. Author's text condensed.

\section{KENTUCKY}

Subject Index

Counties with important asphalt deposits

Breckinridge

Eldridge, G. H., 1901

Foerste, A. F., 1910

Carter

Crider, A. F., 1913

Eldridge, G. H., 1901

Jillson, W. R., 1921b

Richardson, C. H., 1924

Edmonson

Ball, M. W., 1951

Bryant, J. O., 1914

Weller, J. M., 1927

Grayson

Bryant, J. O., 1914

Eldridge, G. H., 1901

Jillson, W. R., 1921a

Moore, F. B., 1964 
Counties with important asphalt deposits - Continued

Grayson - Continued

Richardson, C. H., 1924

Swadley, W. C., 1962

Johnson

Hauser, R. E., 1953

Logan

Ball, M. W., 1951

Eldridge, G. H., 1901

Meade

Richardson, C. H., 1910

Foerste, A. F., 1910

Mining and recovery

Jillson, W. R., 1921c

Moore, F. B., 1964

Swadley, W. C., 1962

Origin

McFarlan, A. C., 1961

Morris, Marshall, 1897

Russell, W. L., 1932

Russell, W. L., 1933

Regional

Ball Associates, Ltd., 1965

Ball, M. W., 1951

Burk, W. E., 1903

Crump, M. H., 1913

Eldridge, G. H., 1901

Jillson, W. R., 1921b

Jillson, W. R., 1927

Jillson, W. R., 1928

McFarlan, A. C., 1961

Morris, Marshall, 1897

Richardson, C. H., 1924

Resources

Ball Assoc., 1965

Ball, M. W., 1951

Crump, M. H., 1913

Hauser, R. E., 1953

Jillson, W. R., 1927

Jillson, W. R., 1928

Richardson, C. H., 1924

Tar seeps

Russell, W. L., 1932

Weller, J. M., 1927

Author List

Ball Associates, Ltd., compiler, 1965, Kentucky, in Surface and shallow oilimpregnated rocks and shallow oil fields in the United States: U.S. Bur. Mines Mon. 12, p. 125-156 [p. 126].

A single trend in Hardin, Grayson, Hart, Edmonson, and Warren Counties accounts for most of Kentucky's reserves of oil-impregnated rocks. A large 
asphaltic deposit occurs in Logan County, and minor accumulations occur in McLean, Breckinridge, Nelson, Estill, Carter, Morgan, and Johnson Counties. The oil-impregnated rocks are Pennsylvanian and Mississippian in age. Reserves are estimated at more than 500 million tons of oil-impregnated material, recoverable from beds, 15 to 30 feet thick, that are covered with about 15 feet of overburden. Average bitumen content is 10-15 gallons per ton. Author's summary condensed.

Ball, M. W., 1951, Report on oil-impregnated strippable deposits in Kentucky as of May 22, 1950, Appendix C, in The synthetic liquid-fuel potential of Kentucky: U.S. Army Corps of Engineers, Summary report for the U.S. Bureau of Mines, Department of the Interior: Ford, Bacon \& Davis, Inc., Engineers.

Eighteen counties in Kentucky are known to contain oil-impregnated deposits. The largest and most important deposits are in the Pottsville (Pennsylvanian) and Cypress (Mississippian) sandstones in central Kentucky. According to estimates as of January 1, 1950, Edmondson and Logan Counties appear to have 434 million tons of oil-impregnated material in place, or 347 million tons recoverable, containing 10-15 gallons of oil per ton in beds 15-35 feet thick and covered by less than 15 to 35 feet of overburden. In Edmonson County, an estimated 4,220 acres contains 196 million tons of recoverable oil-impregnated material; the remaining 151 million tons of recoverable material in Logan County. The oil-impregnated sands of Kentucky are used chiefly for paving. They are composed of fine- to coarse-grained quartz sandstone impregnated with bitumen that is about the consistency of warm tar. The bitumen content averages some 3-7 percent by weight, although some samples have contained more than 10 percent. Author's text condensed.

Bryant, J. O., 1914, The economic geology of a portion of Edmonson and Grayson Counties [Kentucky]: Kentucky Geol. Survey [Repts.], 4th ser., v. 2, pt. 1, p. 155-218 [p. 189-203]. Also published separately, 66 p., 1914.

This report gives a detailed description of each asphalt deposit in Edmonson and Grayson Counties, Kentucky. It also contains a section on the proposed uses of asphalt. Paving was the only use for asphalt in 1914.

Burk, W. E., 1903, Asphalt rock in Kentucky: Eng. and Mining Jour., v. 75, no. 26, p. $969-970$.

Deposits of bituminous sandstone or asphalt rock in Kentucky, which occur chiefly in Logan, Warren, Edmonson, Butler, Grayson, and Breckinridge Counties, occupy a strip that extends through the central part of the State. The area of asphalt-bearing rocks apparently follows the line of the coal measures and is about 20 miles wide and 50 miles long. The deposits are in fine-grained sandstone of Mississippian and Pennsylvanian age. The asphaltic material may represent the residual matter from preexisting petroleum beds. Author's text condensed.

Crider, A. F., 1913, The fire clays and fire-clay industries of the Olive Hill and Ashland districts of northeastern Kentucky: Kentucky Geol. Survey [Repts.], 4th ser., v. 1, pt. 2, p. 589-711 [p. 682-683].

An outcrop of asphalt occurs about 1 mile south of Soldier in Carter County. It is a coarse-grained sandstone that is completely saturated with oil. 
There is an interesting relation of the asphalt to the fire clay of this region. The asphalt rock occupies a geological horizon just above the fire clay. Were it not for the underlying impervious fire clay, the oil in many places would not have collected where it has. In some places the oil has found its way into pockets in the clay.

Crump, M. H., 1913, Kentucky rock asphalt: Kentucky Geol. Survey [Rerts.], 4th ser., v. 1, pt. 2, p. 1053-1065.

Kentucky rock asphalt is found mainly along the southern and eastern outcrops of the western coal field of Kentucky. Geologically, it is in the Chester sandstones and in the lower sandstones of the coal measures, including the Conglomerate sandstone. The sandstone has been saturated with petroleum, which completely coats each face of every sand grain and, thus, forms a cementing material. The content of bituminous matter varies from 5 to 21 percent. The beds are from 3 to 30 feet thick. The material is usually quarried in opencut. It makes excellent paving laid cold and without mixing it with any other asphaltic material, such as tar or artificially prepared asphalt.

Eldridge, G. H., 1901, Asphalt deposits of Kentucky, in The asphalt and bituminous rock deposits of the United States: U.S. Geol. Survey Ann. Rept., 22d, pt. 1, p. 209-452 [p. 240-259], maps.

Bitumens in Kentucky occur as impregnations of sandstones. They are the result of exposure in outcrop of oil-bearing strata, in which the petroleum has been converted by loss of the lighter material and by oxidation into a product of asphaltic nature. The bitumens range in age from Late Mississippian to Early Pennsylvanian. Bituminous sandstone deposits in eastern Kentucky occur in Carter County, near Soldier. The sandstone is composed of fine to coarse sharp sand grains held together by the bitumen. The bitumen content generally ranges from 4 to 6 percent, although locally it is as much as 10 percent. In western Kentucky the bituminous sands crop out in a zone 5-20 miles wide bordering the coal measures. In 1901 quarries were operating in Breckinridge, Grayson, Edmonson, Warren, and Logan Counties.

Foerste, A. F., 1910, Oil, gas, and asphalt rock in Meade and Breckinridge Counties [Kentucky]: Kentucky Geol. Survey Rept. Prog., 1908-1909, p. 69-85.

Tar Spring is about 3 miles south of Cloverport. Water rising from beneath the Tar Spring sandstone carries with it a small quantity of oil, associated with a dark-brown sticky substance, for which Tar Spring was named. The source of this oil is unknown. The sandstone may be serving as a reservoir, rather than as an original source of oil. About 2 miles south of Garfield, the Garfield sandstone has become so thoroughly impregnated with the more solid parts of the oil that the sandstone has been converted to an asphalt rock. Oil must have seeped through the sandstone for a long time, losing the more volatile parts by evaporation. The local distribution of this asphalt suggests that the sandstone served merely as a channel along which the oil gradually seeped upward. The same original source may have supplied both the Garfield and Tar Spring sandstones. Author's text condensed.

Hauser, R. E., 1953, Geology and mineral resources of the Paintsville quadrangle, Kentucky: Kentucky Geol. Survey Bull., ser. 9, v. 13, 80 p. [p. 69-70], illus. and geol. map. 
All saturated sandstone is found within the Lee formation in the western part of the Paintsville quadrangle along Paint Creek and its tributaries. This natural asphalt, 50-75 feet below the top of the Lee formation, ranges in thickness from 4 to 12 feet at outcrop. Thicknesses as much as 90 feet have been reported from oil and gas wells, but these are not confirmed.

Jillson, W. R., 1921a, Geology of oil and gas in Grayson County [Kentucky], in Economic papers on Kentucky geology - An indexed collection of thirteen short papers and reports on the geology and special occurrence of oil and gas, oil shale, asphalt rock, and fluorspar within the Commonwealth: Kentucky Geol. Survey [Repts.], ser. 6, v. 2, 304 p. [p. 186-187].

Asphalt and asphaltic sandstone occur in considerable quantities in several places in Grayson County. They also are found in Edmonson County, to the south, and in Breckinridge County, to the north. The asphalt deposits have been worked in the southern part of Grayson County and in the northern part of Edmonson County. Other deposits have been worked at Tar Hill, a few miles west of Big Clifty, in the northern part of Grayson County. Author's text.

Jillson, W. R., 1921b, Kentucky rock asphalt-The ideal road surface, in Economie papers on Kentucky geology - An indexed collection of thirteen short papers and reports on the geology and special occurrence of oil and gas, oil shale, asphalt rock, and fluorspar within the Commonwealth: Kentucky Geol. Survey [Repts.], ser. 6, v. 2, 304 p. [p. 39-57].

Kentucky asphalt rock occurs in its natural position as an asphaltimpregnated sand, 5-40 feet thick, along the eastern and southeastern border of the western coal field in Hart, Grayson, Edmonson, Warren, Butler, Logan, Breckinridge, and adjoining counties. Asphaltic sandstone has also been found on Soldier and Mocabee Creeks in Carter County, and in the cliffs of Big Paint Creek and its tributaries in Johnson County and adjacent parts of Morgan and Magoffin Counties. The asphalt is in the Chester sandstones of Mississippian age and in the overlying Pottsville conglomerate sandstone of Pennsylvanian age. Commercially, the best and most workable deposits are in the Pottsville in west-central Kentucky. This report contains a section on mining and preparation of the asphalt rock for paving.

Jillson, W. R., 1921c, A new method of producing crude oil in Kentucky: Kentucky Geol. Survey [Rept.], ser. 6, v. 6, p. 149-154.

Experimental work was done at Ravenna, Estill County, Ky., on "mining" crude oil. An 8 - by 12-foot shaft was sunk 130 feet through the Chatanooga (Devonian) shale to the underlying oil sand, the Onondaga limestone. Oil was produced from the Onondaga in quantities averaging 2 to 3 barrels per day. The practicality of this venture had not been proved by the time this report was written.

Jillson, W. R., 1927, Kentucky rock asphalt, in The topography of KentuckyA systematic study and classification of all the prominent physical features of Kentucky coupled with an indexed collection of twenty-four separate papers on the geology and mineral resources of the Commonwealth: Kentucky Geol. Survey [Repts.], ser. 6, v. 30, 291 p. [p. 95-103]. 
The term "rock asphalt" has become standard for bituminous sandstones sufficiently impregnated with petroliferous residues of an asphaltic nature as to contain 5 to 15 percent bitumen. The rock asphalts of Kentucky are well exemplified in type deposits, ranging in thickness from 20 to 50 feet, in west-central Kentucky, in Edmonson, Hart, Grayson, Breckinridge, Warren, and Logan Counties. Stratigraphically, these deposits occur in the Chester (Upper Mississippian) and Pottsville (Lower Pennsylvanian) rocks. The asphalts of the older, Chester rocks are the more widely distributed. This report contains a sketch map of the Chester and Pottsville rock asphalts in Kentucky.

Jillson, W. R., 1928, The geology and mineral resources of Kentucky: Kentucky Geol. Survey [Repts.], ser. 6, v. 17, 409 p. [p. 134, 143, 155, $225,373]$.

This is a county by county evaluation of the geology and mineral resources of Kentucky. The asphalt deposits of Grayson, Hardin, Logan, and Warren Counties are discussed.

McFarlan, A. C., 1961, Rock asphalt, in Geology of Kentucky: Lexington, Ky., Kentucky Univ., 531 p. [p. 382-384].

Kentucky rock asphalt is a coarse-grained sandstone thoroughly impregnated with bitumen that is about the consistency of warm tar. The bitumen content varies from a trace to complete saturation. Commercial rock is virtually saturated, but, because of differences in original porosity, the bitumen content varies from 3 or 4 percent to about 15 percent. Edmonson County leads in asphalt production, and Grayson County is second. The deposits in Edmonson County are mainly in the basal sandstone of the Caseyville sandstone and in the overlying Bee Spring sandstone, where it forms the base of the Pottsville. The Kentucky rock asphalt deposits are actually "defunct" oil pools. The asphalt beds are, thus, oil sands from which the more volatile hydrocarbons have been lost. Alteration was begun by ground-water circulation while the oil sand was still buried. Exposure to the atmosphere completed the process. Author's text condensed.

Moore, F. B., 1964, Geology of the Summit quadrangle, Kentucky: U.S. Geol. Survey Geol. Quad. Map GQ-298, with sections and text.

Two quarries near Summit in the upper part of the Big Clifty Sandstone Member were worked for rock asphalt until the late 1930's, when depletion of reserves led to their abandonment. Author's text condensed.

Morris, Marshall, 1897, Kentucky bituminous rock: Eng. and Mining Jour., v. 63 , no. 2 , p. 46 .

Bituminous rock deposits are found in Breckinridge, Grayson, Edmonson, and Logan Counties, Ky. There is little doubt that these deposits were once oil-bearing sands, which, by long exposure, have been oxygenized, leaving the rock impregnated with the last residue of the series, naphtha, petroleum, mineral tar, and asphaltum. The impregnated rock is not found in distinct veins with well-defined partings from bed to roof, as is true of coal, but more in the shape of pockets or pools of greater or lesser area, and varying in thickness from the rim to the center of the basin. The greatest known thickness is 10 feet. It cannot be economically removed by tunneling or mining, but 
must be stripped of the overlying sandstone and partially impregnated rock. The sandstone is a fine-grained white sand - nearly pure silica. The bitumen content is as much as $\mathbf{1 2}$ percent, but the average "good" material contains about 8 percent. Author's text condensed.

Richardson, C. H., 1924, The road materials of Kentucky: Kentucky Geol. Survey [Rept.], ser. 6, v. 22, 209 p. [p. 54, 84, 158-162, 168].

Sandstones impregnated to various degrees with asphaltic material occur at Soldier, in western Carter County. The deposit is estimated to be 3 miles long and three-quarters of a mile wide. It ranges in thickness from 4 to 22 feet. The asphalt content averages 7 percent. There are several rock asphalt deposits in Grayson County; some are being produced, whereas others still need careful core drilling and analyses before their value is known. In Logan County, sandstones impregnated with a thick tarry oil were worked 4 miles northeast of Russelville. Some of these deposits were 18 to 20 feet thick. Author's text condensed.

Russell, W. L., 1932, Geology of oil and gas fields of western Kentucky: Am. Assoc. Petroleum Geologists Bull., v. 16, no. 3, p. 231-254.

Though in Paleozoic formations, the oil field of western Kentucky is exceptionally rich in surface indications, partly because of the shallow depth of the pools and because of the nearby exposure of the producing strata. The surface indications consist of oil and gas seeps and of sandstones and limestones impregnated with asphalt or tarry substances. Oil and gas seeps occur in outcrops of the Silurian and Devonian limestones on the east side of the basin and along the Rough Creek anticline in McLean and Webster Counties. Asphaltic sandstones are plentiful in the Chester series on the east and southeast sides of the basin. Most surface indications are at the outcrops of horizons that produce oil. The seeps along the Rough Creek anticline, where lower Pennsylvanian and even Chester rocks are at the surface, may be caused by migration of the oil updip through the tilted strata, or they may be due to vertical migration along the fault planes. Author's text condensed.

Russell, W. L. 1933, The origin of the asphalt deposits of western Kentucky: Econ. Geology, v. 28, no. 6, p. 571-586, 2 figs. incl. map.

Some of the asphalt deposits have accumulated along faults, where they form structural traps for oil moving updip; however, in general, the deposits are not related to faults. The oil from which the asphalt was derived probably did not come from the Chatanooga shale. In some places, the oil which formed the asphalt moved a few miles updip, but its movement was generally less than 15 miles. The field relations suggest the oil from which the asphalt was produced was generated from shales of the Chester series that yield ammonia on distillation, but Osage, lower St. Louis, and Chester bituminous rocks may also be considered possible sources. Author's conclusions.

Swadley, W. C., 1962, Geology of the Big Clifty quadrangle, Kentucky: U.S. Geol. Survey Geol. Quad. Map GQ-192, with sections and text.

Asphaltic sandstone in the Big Clifty Sandstone Member of the Golconda Formation has been mined for rock asphalt for road-surfacing material. Two mines (1.9 miles south of Tar Hill, and 1.0 mile southwest of Big Clifty) were worked intermittently and then abandoned during the 1930's. They are 
marked by partially caved adits. Asphaltic sandstone has been extensively mined for rock asphalt from the basal beds of the Caseyville Formation of Early Pennsylvanian age in areas south of this quadrangle. Author's text condensed.

Weller, J. M., 1927, The geology of Edmonson County [Kentucky]: Kentucky Geol. Survey [Rept.], ser. 6, v. 28, 246 p. [p. 199-215], 56 figs. and pls.

Rock asphalt deposits occur in Logan, Warren, Edmonson, Grayson, Hardin, Breckinridge, and Hancock Counties. The deposits in Edmonson County are, by far, the most important economically and have had the most development $-11 / 2$ million tons of rock asphalt had been produced by 1927 . Kentucky rock asphalt has its chief market as a material for surfacing streets and highways. In Edmonson County, sandstones of Chester and Pottsville age are impregnated with enough bitumen to be considered rock asphalt. Local exploration of the asphalt beds has been quite erratic, despite their wide occurrence. These beds pinch and swell, thickening and thinning without apparent cause. The freshly broken rock asphalt has a dense black surface upon which the individual sand grains cannot be seen because of their coating of bitumen. High-grade rock is sticky to the touch. When struck with a hammer, the highgrade rock does not break into small pieces or disintegrate; rather, it mashes into a flat, compact mass. In some places the bitumen that impregnates the sandstone issues in such quantities as to be called "tar springs." The bitumen is clearly derived from petroleum. At one time, the entire asphalt district was an oil field, and the asphaltic beds are actually fossil-oil sands from which the more volatile hydrocarbons have escaped. Author's text condensed.

\section{MICHIGAN}

\section{Subject Index}

Asphalt associated with copper

Devonian

Carlson, C. G., 1932

Dundee Formation

Sherzer, W. H., 1913

Oil seeps

Sherzer, W. H., 1900

Sherzer, W. H., 1913

Ordovician

Trenton Limestone

Ball Associates, Ltd., 1965

\section{Author List}

Ball Associates, Ltd., compiler, 1965, Michigan, in Surface and shallow oilimpregnated rocks and shallow oil fields in the United States: U.S. Bur. Mines Mon. 12, p. 159-160 [p. 160].

Most of Michigan is blanketed by glacial deposits, and outcrops of Paleozoic formations cover only a very small area. One oil-impregnated limestone is reported in the Ordovician of the Upper Peninsula. It is an asphalt-impregnation of the upper Trenton limestone. Here a dark bituminous limestone crops out over a large area in the vicinity of the Rapid and White Fish 
Rivers. One locality is reported to have a 300 -foot-thick deposit of oily and bituminous limestone. Oil is reported to impregnate the rock, and "asphaltum gum" fills fissures and cavities.

Carlson, C. G., 1932, Bitumen in Nonesuch formation of Keweenawan series of northern Michigan: Am. Assoc. Petroleum Geologists Bull., v. 16, no. 8, p. 737-740.

The bituminous matter in the Nonesuch formation is found as a cement in the sandstones of this formation and in fractures and fissures related to crossfaulting. Pieces weighing as much as 20 pounds composed largely of bitumen have been obtained from cross-faults at the White Pine and White Pine Extension mines. Much of the disseminated bitumen is closely associated with native copper. The copper replaces the chlorite fringe around the bitumen and part of the adjacent mineral or rock grains. The bitumen, therefore, was present in the Nonesuch beds prior to the deposition of the copper. The maximum amount of bituminous cementing material is about 2 percent. The black shales of the Nonesuch formation appear to be the most probable source material of the bitumen. These shales are bituminous and yield a tarry distillate when heated in a glass tube. Author's text condensed.

Sherzer, W. H., 1900, Geological report on Monroe County, Michigan: Michigan Geol. Survey, v. 7, pt. 1, 240 p. [p. 190-191], map.

There is an area containing strong surface indications of oil and combustible natural gas in the northwestern part of Monroe County, Mich. The oil impregnates the rocks and forms a scum on the surfaces of ponds, streams, and wells. The oil is associated with the St. Clair, Traverse, and Dundee formations.

Sherzer, W. H., 1913, Geological report on Wayne County [Michigan]: Michigan Geol. Survey Pub. 12, Geol. Ser. 9, 388 p., maps.

In southeastern Michigan and western Ontario, the Dundee formation (Devonian) is mainly a pure limestone containing scattered nodules, seams, and thin strata of chert. The beds commonly give a strong odor of oil and show drops of thick black bituminous matter in small cavities. In Ontario and near Port Huron, the formation yields oil and gas where structural conditions have been favorable. Author's text condensed.

\section{MISSISSIPPI}

\section{Author List}

Ball Associates, Ltd., compiler, 1965, Mississippi, in Surface and shallow oilimpregnated rocks and shallow oil fields in the United States: U.S. Bur. Mines Mon. 12, p. 161-164 [p. 161].

The known petroleum-impregnated outcrops in Mississippi are in the extreme northeast, in Tishomingo County. These are outcrops of asphaltic oolites in the Gasper and Bethel formations that extend west from Alabama. These formations are part of the Lower Bangor limestones and shales of Mississippian (Chester) age.

Lowe, E. N., 1919, Oil and gas prospecting in Mississippi: Mississippi Geol. Survey Bull. 15, 80 p., 1 pl., 1 fig., 1 map. 
The extensive arching of the Cincinnati anticline passes through central Kentucky and Tennessee into northwestern Alabama and finds expression in the rocks of northeastern Mississippi. Mississippian age beds present are called the Lauderdale chert, Tuscumbia limestone, and Hartselle sandstone. Both limestones and sandstones are often bituminous, and in adjacent counties of Tennessee and Alabama, oil shows, gas, and tar springs are frequent. Author's text condensed.

\section{MISSOURI}

Subject Index

Analyses

Dake, C. L., 1918b

Hail, W. J., Jr., 1957

Searight, W. V., 1967

Counties with asphalt deposits

Barton

Buckley, E. R., and Buehler, H. A., 1904

Crabtree, E. H., and Netzeband, W. F., 1935

Dake, C. L., 1918 b

Cass

Clair, J. R., 1943

Lafayette

Dake, C. L., 1918a

Eldridge, G. H., 1901

Vernon

Crabtree, E. H., and Netzeband, W. F., 1935

Dake, C. L., 1918b

Greene, F. C., and Pond, W. F., 1926

Hail, W. J., Jr., 1957

Mining and quarrying operations

Bishop, O. M., 1950

Buckley, E. R., and Buehler, H. A., 1904

Clair, J. R., 1943

Regional

Crabtree, E. H., and Netzeband, W. F., 1935

Anderson, K. H., and Wells, J. S., 1967

Ball Associates, Ltd., 1965

Bishop, O. M., 1950

Dake, C. L., 1918b

Eldridge, G. H., 1901

Enright, R. J., 1964

Searight, W. V., 1957

Searight, W. V., 1967

Smith, W. S. T., and Siebenthal, C. E., 1908

Wells, J. S., and Anderson, K. H., 1968

Wilson, M. E., 1922

Recovery methods

Anderson, K. H., and Wells, J. S., 1967

Ball Associates, Ltd., 1965

Enright, R. J., 1964

Marx, J. W., and Trantham, J. C., 1965 
Recovery methods - Continued

Trantham, J. C., and Marx, J. W., 1966

Valleroy, V. V., Willman, B. T., Campbell, J. B., and Powers, L. W., 1967

Wells, J. S., and Anderson, K. H., 1968

Resources

Greene, F. C., and Pond, W. F., 1926

\section{Author List}

Anderson, K. H., and Wells, J. S., 1967, Oil and gas, in Mineral and water resources of Missouri: Missouri Div. Geol. Survey and Water Resources [Rept.], 2d ser., v. 43, p. 243-252.

Low-gravity high-viscosity oil has been known in western Missouri for at least 100 years. It has been reported as "tar springs," as "pitch," as "asphalt," and commonly described simply as "heavy oil." The material ranges from a true oil of low gravity and high viscosity present at shallow depths to a bituminous, or asphaltic, residue developed where the oil-bearing formations occur at or near the surface. The viscous low-gravity oils of western Missouri occur in sandstones of the middle and lower parts of the Cherokee Group. The oil-bearing sands are widespread and occur over large areas at depths of only a few hundred feet. The low-viscosity low-gravity material is differentiated from the producible Missouri crudes, whose gravity may average 27 or 28 and which can be produced by pumping, with additional recovery through water flooding. Author's text condensed.

Ball Associates, Ltd., compiler, 1965, Missouri, in Surface and shallow oilimpregnated rocks and shallow oil fields in the United States: U.S. Bur. Mines Mon. 12, p. 164-192 [p. 167].

Oil-impregnated rocks occur at or near the surface in 21 counties in western Missouri. Mississippian age asphaltic rocks occur in the zinc-lead-mining area of Jasper County and along the outcrop of the Pennsylvanian-Mississippian contact. The Boone Formation contains most of these Mississippian deposits - asphaltic limestones averaging 10 feet thick. One isolated Mississippian asphaltic sandstone is in Barry County in the Batesville Formation. Asphaltic sandstones of Pennsylvanian age are most numerous throughout western Missouri, especially in Vernon County, where they have the greatest aggregate thickness (30 feet): They are reported in six formations in the Des Moines and Missouri rocks, chiefly in the Cherokee Shale and Pleasanton Group. Bituminous limestones are found in the Pennsylvanian Bethany Falls and Fort Scott Formations. Missouri rock asphalts range in bitumen content from a trace to 15 percent. Shell Oil Co. is experimenting with a pilot thermaloil-recovery project in Vernon County. Author's text condensed.

Bishop, O. M., 1950, The mineral industry of Missouri in 1948: Missouri Div. Geol. Survey and Water Resources Inf. Circ. 6, 21 p. [p. 5], table.

Asphaltic sandstone of Pennsylvanian age crops out in several counties of western and southwestern Missouri. Mining operations in Barton or Vernon Counties have produced several tens of thousands of tons of asphaltic sandstone, which has been used as paving material in Missouri, Kansas, Illinois, Indiana, Nebraska, and Iowa. 
Buckley, E. R., and Buehler, H. A., 1904, The Liberal Stone and Coal Co. quarries, in The quarrying industry of Missouri: Missouri Bur. Geology and Mines [Rept.], 2d ser., v. 2, 371 p. [p. 263-265], maps.

The asphaltic sandstone quarry of the Liberal Stone and Coal Co. is 2 miles north of Liberal in the NW1/4 $\mathrm{SE}^{1 / 4}$ sec. $23, \mathrm{~T} .33 \mathrm{~N}$., R. $33 \mathrm{~W}$. The sandstone is very fine grained and micaceous, and has a black appearance, owing to the asphalt content. The stone is sawed parallel to the bedding and cut into pieces suitable for crosswalks, sidewalks, and curbing. The large amount of asphalt in the stone causes moisture absorption to be very low compared with that of rock from other quarries. On the sawed surface, weathering sometimes loosens small pieces which fall away, leaving shallow depressions in the stone. Samples of both ordinary and asphaltic sandstones from this quarry were tested to determine their strength and durability. The results of these tests show the superior quality of the asphaltic over the ordinary yellow sandstone. The asphaltic sandstone has a higher strength; the porosity is about one-third that of the yellow sandstone; and for the samples tested, the asphaltic sandstone lost nothing in strength through freezing and thawing, whereas the yellow sandstone lost about $331 / 3$ percent. Authors' text condensed.

Clair, J. R., 1943, The oil and gas resources of Cass and Jackson Counties, Missouri: Missouri Div. Geol. Survey and Water Resources [Rept.], 2d ser., v. 27, 208 p. [p. 24-25], illus., incl. geol. maps.

In the old Weiser rock quarry in sec. $8, T .44$ N., R. 33 W., just west of the village of West Line, the upper 2 to 3 feet of the Bethany Falls, which is generally nodular, becomes very oolitic. This oolitic zone is so saturated with heavy oil that, on extremely hot summer days, the quarry face will "bleed" oil. This condition seems to be restricted to this area in Cass County, although it has been reported to occur at other exposures in this immediate vicinity. Author's text modified.

Crabtree, E. H., and Netzeband, W. F., 1935, Quarry and plant of Reliance Rock Asphalt Co.: Mining and Metallurgy, v. 16, no. 339, p. 159.

The asphalt-bearing sandstones are found at two general horizons in Barton and Vernon Counties - one near the base of the Cherokee (Bartlesville), and the other higher up in a sandstone that may be the equivalent of the Red Fork sand of Oklahoma. This upper sand is the productive sandstone at the Reliance Rock Asphalt plant. The lower sandstone has been found impregnated with asphalt for a thickness of as much as 30 feet, but the usual thickness of the asphalt-bearing part is less than 20 feet. The upper sandstone is impregnated with commercial quantities of asphalt, for a thickness of 10 to 15 feet, which is covered by an overburden, commonly 5 to 10 feet thick, of lean asphalt-bearing sandstone. The bitumen content of the sandstones varies from a trace in the noncommercial parts to as much as 14 percent by weight. Authors' text condensed.

Dake, C. L., 1918a, The Higginsville deposit, in The sand and gravel resources of Missouri: Missouri Bur. Geology and Mines [Rept.], 2d ser., v. 15,274 p. [p. 186-188].

The Higginsville deposit of bituminous sandstone is exposed in a dry creekbed three-quarters of a mile northwest of Higginsville, in Lafayette County. The deposits occur in the Warrensburg sandstone of Pennsylvanian 
age. The sandstone itself, where not filled with bitumen, is a light gray, micaceous, fine grained, and even textured. The individual grains are mostly well rounded or subangular, and cemented together rather loosely; as a result, the rock is friable and easily cut with a pick. Where it is saturated with bitumen, the rock is dark brown to black, but exposed surfaces lose the bitumen through evaporation, which indicates that the bituminous material contains little asphaltine (7.4 percent). Author's text condensed.

Dake, C. L., 1918b, The sand and gravel resources of Missouri: Missouri Bur. Geology and Mines [Rept.], 2d ser., v. 15, 274 p. [p. 181-189].

Sandstone containing bitumen occurs extensively in western Missouri, where the Lower Pennsylvanian strata crop out. The bituminous matter is a heavy black crude, rather than a true asphalt. These bituminous sandstones occur mainly in Barton, Vernon, Bates, Cass, Lafayette, and Cedar Counties; also, lesser amounts occur in Jackson, Ray, Carroll, and Caldwell Counties. The most extensive deposits are those in northern Barton and southern Vernon Counties. The bituminous sandstones occur in the Lower Pennsylvanian rocks - the Cherokee shale, the Henrietta and Pleasonton formations, and the Warrensburg sandstone. The most extensive deposits are in the Cherokee shale. The bitumen present is probably the result of inspissation of crude petroleum originally contained in the sandstone, through exposure and consequent evaporation. At most localities, the bituminous matter is chiefly a heavy black viscous oil, which flows readily in warm weather. Two analyses of the bitumen from Vernon County show 10.5 and 12.5 percent asphaltine, and 87.5 and 89.5 percent petrolene. Relative to the use of crushed rock for paving, the fact that the bitumen is chiefly a petroleum instead of an asphalt is an unfavorable factor. The average percentage of asphaltine is much lower than the average for the Oklahoma deposits, which is 21-28 percent.

Eldridge, G. H., 1901, Missouri asphalt deposits, in The asphalt and bituminous rock deposits of the United States: U.S. Geol. Survey Ann. Rept., 22d, pt. 1, p. 209-452 [p. 259-261], maps.

The only asphalt deposits known when this report was written were in the region around Higginsville, Lafayette County, and near Odessa, 15 miles to the west. The deposits occur in the Pennsylvanian Warrensburg sandstone, an apparent channel deposit.

Enright, R. J., 1964, Heavy oil - A billion-barrel prize: Oil and Gas Jour., v. 62 , no. 24 , p. $41-44$.

There is a vast reserve of heavy oil just below the surface in blanket-type sands covering several hundred square miles in the Kansas-Missouri border area. This huge hydrocarbon deposit lies at very shallow depths along the eastern rim of the Cherokee basin. The sands lap over the Bourbon arch in the Vernon County, Mo., area, and continue northward, gradually deepening, to the south edge of Kansas City, in Jackson County. Only Shell Oil Co. was testing the feasibility of commercial production from these sands in June 1964, but one or two other major companies were planning tests. All use either the steam or fire-flood techniques.

Greene, F. C., and Pond, W. F., 1926, The geology of Vernon County [Missouri]: Missouri Bur. Geology and Mines [Rept.], 2d ser., v. 19, 152 p. [p. 109-115], 14 figs., 14 pls., incl. map. 
Sandstones containing bitumen and asphaltic material crop out in several places in Vernon County and have been found in wells and drill holes. Most occurrences are in the Clear Creek sandstone member of the Cherokee formation, but a few thin ledges are found higher in the Cherokee and in the sandstones of the Labette shale member of the overlying Henrietta formation. In those occurrences likely to prove commercially valuable, there is at least 10 feet, and in places 30 feet, of bituminous material over a considerable area, mostly under less than 5 feet of overburden. The bitumen forms the cementing material, and when it is removed, the rock crumbles easily. The average bitumen content is probably less than 10 percent. The bitumen is derived from crude petroleum, through the evaporation of lighter constituents near the sandstone outcrop.

Hail, W. J., Jr., 1957, Missouri, in Reconnaissance for uranium in asphaltbearing rocks in the Western United States: U.S. Geol. Survey Bull. 1046-E, p. 55-85 [p. 76], illus., incl. geol. sketch map.

The asphalt deposits in all five areas examined in Vernon County, Mo., occur in one or more lenticular sandstone beds in the Cherokee shale (Pennsylvanian). The rock containing the asphalt is mainly fine-grained micaceous quartzose sandstone. Most of the samples collected in Missouri do not contain above-average amounts of uranium; however, one sample from the Ellis area yielded 0.40 percent uranium in the ash of the extracted oil. Author's text condensed.

Marx, J. W., and Trantham, J. C., 1965, Reverse combustion produces altered crude oil: Oil and Gas Jour., v. 63, no. 20, p. 123-127 [p. 123].

Results from a 3-year field test in a Missouri tar sand and from laboratory tests on a Venezuelan crude show differences between oil in place and that produced from a counterflow in-situ-combustion process. Counterflow combustion in which air flows in a direction opposite to that of the fire front is needed in reservoirs where the heat-thinned crude congeals on contact with cool reservoir rock, shutting off air. Forward combustion cannot be maintained in such places, and examples of this are found in the tar sands of Missouri and in some Venezuelan reservoirs. In forward combustion, the crude is produced with little change in reservoir conditions, whereas that produced by counterflow or reverse combustion is a distilled product.

Searight, W. V., 1957, Asphaltic rocks in western Missouri: Missouri Div. Geol. Survey and Water Resources Inf. Circ. 13, 26 p.

Bituminous sandstones and limestones are present at or near the surface in 21 or more counties of western Missouri. These rocks range in stratigraphic position from the Batesville sandstone of Mississippian age upward into the Raytown limestone of Pennsylvanian age. The bituminous matter is a residue derived from petroleum which originally contained both paraffins and asphalt, together with naphthenes and aromatics. Modification of the original matter results from loss of volatile aromatics by evaporation and by complex chemical changes attendant to weathering. Processed bituminous sandstones from Missouri have been marketed to some extent for city paving where traffic is relatively light, surfacing of private driveways, tennis courts, and similar projects. Some of the bituminous matter is appreciably radioactive, but none is known to contain radioactive matter in sufficient quantity to be of commercial value. Author's abstract. 
This report includes a map of western Missouri, showing the locations of asphaltic rock.

Searight, W. V., 1967, Asphaltic sandstone, in Mineral and water resources of Missouri: Missouri Div. Geol. Survey and Water Resources [Rept.], 2d ser., v. 43 , p. $155-157$.

Sandstones and limestones impregnated with bituminous matter lie at or near the surface in at least 21 counties in western Missouri. The bituminous matter is a residue derived from petroleum that has lost most of the volatile aromatics by evaporation and chemical change. The bituminous content is as much as 15.2 percent by volume, or 6.4 percent by weight. The sandstones of the Krebs Subgroup of the Cherokee Group are the best known and the most readily available, particularly the sandstone of the Bluejacket Formation in Vernon and Barton Counties. Continuity of sands from area to area has not been established, but several areas in Vernon and Barton Counties are underlain by as much as 30 feet of such rocks. Author's text condensed.

Smith, W. S. T., and Siebenthal, C. E., 1908, Description of the Joplin district [Mo.-Kans.]: U.S. Geol. Survey Geol. Atlas, Folio 148, 20 p. [p. 13], maps.

Bitumen, known as "tar" by the miners, is found in various amounts in all rocks of the Joplin district. Its occurrence in appreciable quantity, however, is generally restricted to the vicinity of the ore deposits. Though usually in small quantity, the bitumen is locally sufficient to interfere with the milling of the ores and, in a few places, to clog the pumps. The source of the bitumen in the mines is probably the Boone limestone, for bitumen is most abundant in the ores where limestone predominates in the adjacent country rocks. Authors' text condensed.

Trantham, J. C., and Marx, J. W., 1966, Bellamy field tests - Oil from tar by counterflow underground burning: Soc. Petroleum Engineers, Am. Inst. Mining, Metall., and Petroleum Engineers Trans., v. 237, pt. 1, p. 109-115.

From 1955 to 1958 the Phillips Petroleum Co. conducted a series of smallscale counterflow-combustion field tests in a tar sand, about 60 feet deep and 6-12 feet thick, near Bellamy, Mo. Direct-drive ignition followed by reversal to counterflow operation was not possible in this tar sand because of formation plugging by the semisolid tar during the direct-drive phase. Substantial counterflow burning was achieved with wellbore fuel packs under controlled conditions, which permitted close correlation of fire-front velocity, air velocity, air-oil ratios, and yields for a wide variation in process parameters. The tar in place was about $10^{\circ} \mathrm{API}$, with a reservoir viscosity greater than 500,000 centipoise. The volume of oil recovered during stabilized line-drive counterflow burning represented about 67 percent of the volume of tar originally in place in the burned-out zones. Authors' abstract condensed.

Valleroy, V. V., Willman, B. T., Campbell, J. B., and Powers, L. W., 1967, Deerfield pilot test of oil recovery by steam drive: Soc. Petroleum Engineers, Am. Inst. Mining, Metall. and Petroleum Engineers Trans., v. 240 , pt. 1 , p. $956-964$.

A steam drive of heavy oil was field tested in a shallow low-oil-saturation formation near Deerfield, Mo. The pilot was conducted in the Warner forma- 
tion, a sandstone containing an $18^{\circ}$ API oil having 1,000 centipoise viscosity at the $60^{\circ} \mathrm{F}$ original reservoir temperature. The formation was at a depth of 160 feet. From the test area about 7,000 barrels of oil were produced. This field test of a steam drive demonstrated the feasibility of the method, confirmed that the low residual-oil saturations observed in the laboratory are obtained in the steam-swept region of the field, and provided recovery and conformance data for one set of field conditions. Authors' abstract condensed.

Wells, J. S., and Anderson, K. H., 1968, Heavy oil in western Missouri: Am. Assoc. Petroleum Geologists Bull., v. 52, no. 9, p. 1720-1731.

Low-gravity high-viscosity oil is present in discontinuous sandstone bodies at shallow depths in at least 21 western Missouri counties. Asphaltic sandstone beds are present from the lower Cherokee (Middle Pennsylvanian) section in Barton and Vernon Counties to the upper Pleasanton (Upper Pennsylvanian) section in Lafayette and Carroll Counties. Bitumen deposits are present in Mississippian and Pennsylvanian limestone beds. Pilot thermalrecovery projects in Vernon and Cass Counties have produced a composite oil product of $15^{\circ}-21^{\circ}$ API gravity; the original reservoir oil was $10^{\circ}$ or less API gravity. The recoverable oil of $25^{\circ}-28^{\circ}$ API gravity at depth in the northern part of the area changes to highly viscous low-gravity oil in the southern part toward the outcrop of the reservoir rocks. Isolated concentrations of heavy oil and the discontinuous nature of sandstone bodies are attributed to depositional environments resulting from minor tectonic movements and the former presence of structural features. Authors' abstract condensed.

Wilson, M. E., 1922, The occurrence of oil and gas in Missouri: Missouri Bur. Geology and Mines [Rept.], 2d ser., v. 16, 284 p. [p. 19-21, 250-258], 11 pls., incl. maps.

Asphaltic sandstone is found in outcrop in Barton, Vernon, Bates, Caldwell, Ray, Carroll, Lafayette, Johnson, Cedar, St. Clair, Hickory, and Barry Counties. Known outcrops of asphaltic limestone of Pennsylvanian age are restricted to Bates, Cass, Jackson, and Caldwell Counties, the most important being in west-central Cass County. With the exception of the Mississippian limestone beds, which probably received their bitumen from the Pennsylvanian, the asphaltic sandstones and limestone are all Pennsylvanian in age. The asphaltic sandstones occur in the Cherokee, Henrietta, Pleasanton, and Warrensburg formations. The only asphaltic formation of Late Pennsylvanian age is the Bethany Falls limestone in Cass, Jackson, and Caldwell Counties. The bituminized strata are distributed stratigraphically from the base of the Cherokee formation to the lower part of the Kansas City formation, a little more than 700 feet of strata. The most important and extensive deposits are in the Cherokee, Pleasanton, and Warrensburg formations. Author's text condensed.

\section{MONTANA}

Subject Index

Analyses

Ball Associates, Ltd., 1965

Hail, W. J., Jr., 1957 
Cretaceous

Regional

Stebinger, Eugene, 1918

Ball Associates, Ltd., 1965

Pennsylvanian

Tensleep Sandstone

Thom, W. T., 1923

Stillwater Basin

Triassic

Calvert, W. R., 1917

Chugwater Formation

Ball Associates, Ltd., 1965

Hail, W. J., Jr., 1957

Knappen, R. S., and Moulton, G. F., 1931

\section{Author List}

Ball Associates, Ltd., compiler, 1965, Montana, in Surface and shallow oilimpregnated rocks and shallow oil fields in the United States: U.S. Bur. Mines Mon. 12, p. 192-197 [p. 192].

The known outcrops of petroleum-impregnated rocks are widely scattered in a few concentrations. The most widespread occurrence is in south-central Montana, in the northern Bighorn Basin and along the northern flank of the Bighorn Mountains. At Red Dome, in Carbon County, asphalt impregnating the Chugwater Formation (Triassic) covers about $1 \frac{112}{2}$ square miles at the structural crest of Red Dome. The impregnation is in the top 20 to 27 feet of the formation. The color of the Chugwater red beds has been altered to green. Analyses show oil content to range from 2.45 to 6.60 percent. "More or less tarry" outcrops of Tensleep Sandstone (Pennsylvanian) occur on the Little Horn River and Lodgegrass Creek. The usual color of the Triassic red beds has been altered to a greenish tint by the oil. The outcrops are around the flanks of Sport Creek Dome.

Calvert, W. R., 1917, Geology of the Upper Stillwater Basin, Stillwater and Carbon Counties, Montana, with special reference to coal and oil: U.S. Geol. Survey Bull. 641-G, p. 199-214.

In the $\mathrm{SE}^{1} / 4$ sec. 32 , T. 6 S., R. $18 \mathrm{~W}$., indications of oil were reported in wells drilled 600-1,100 feet deep. At three points nearby, small pools of asphalt occur, and in 1908 these pools were being augmented by asphalt oozing from the ground. Geologic relations are obscured by thick growths of quaking aspen, but it was ascertained that the drilling was done in Fort Union rocks that dip toward the Beartooth fault at any angle of $22^{\circ}$. The stratigraphic horizon of the oil is in doubt, and whether the oil is indigenous to the Fort Union beds or rose along the Beartooth fault from some lower horizon is uncertain. Evaporation dissipated the volatile portion, and the residue remains as asphalt. The fact that this bituminous residue is present at the surface suggests that oil in large quantity is not likely to be found in the strata from which the asphalt oozed. Author's text condensed.

Hail, W. J., Jr., 1957, Montana, in Reconnaissance for uranium in asphaltbearing rocks in the Western United States: U.S. Geol. Survey Bull. 1046-E, p. 55-85 [p. 71]. 
Asphalt-bearing sandstone in the Triassic Chugwater formation crops out along the rim of the breached top of Red Dome, Carbon County. The asphalt contains relatively small amounts of uranium. The asphalt impregnates the top 20-27 feet of the uppermost sandstone of the Chugwater. Asphalt-bearing sandstone is exposed only along the steep inner rim of the dome. The uranium in the ash ranges from 0.009 to 0.013 percent in the ash of the extracted oil. Author's text condensed.

Knappen, R. S., and Moulton, G. F., 1931, Geology and mineral resources of parts of Carbon, Big Horn, Yellowstone, and Stillwater Counties, Montana: U.S. Geol. Survey Bull. 822-A, p. 1-70.

The Chugwater sandstone on top of Red Dome, in secs. 17 and 18, T. 7 S., R. 24 E., and adjacent areas, has been bleached along the top by the accumulation of hydrocarbons against the overlying impervious shales of the Sundance formation. The rock has lost its normal red color and has become gray through reduction of the original hematite. This bleaching is observed not only in the upper layers of the formation on the crest of the dome, but also along joint planes for vertical distances as much as 200 feet beneath the top of the formation, indicating that the oil migrated up along these joints. Most of this oil has, of course, escaped, for erosion has stripped away the cover from the dome. Much of the sandstone still contains enough oil to stain the fingers with a sticky black viscous residue of partly evaporated petroleum. This is the only known place within the area where oil actually appears at the surface. Authors' text condensed.

Stebinger, Eugene, 1918, Oil and gas geology of the Birch Creek-Sun River area, northwestern Montana: U.S. Geol. Survey Bull. 691-E, p. 149-184.

There are at least three widely separated localities in the Birch CreekSun River area where the basal shale beds of the upper Colorado shale (Upper Cretaceous) are only slightly disturbed, and, thus, their stratigraphic position can be ascertained. The petroliferous beds have an average thickness of about 50 feet throughout the area, and consist of compact black bituminous shale containing thin beds of impure limestone that, in places, is impregnated along fractures with a soft tarry bitumen. The northernmost of these "oil showings" was found on the south side of the Middle Fork of Dupuyer Creek in the SW $1 / 4 \mathrm{SW}^{1 / 4}$ sec. 18, T. 27 N., R. 8 W. At this locality, about 10 feet of dark Colorado shales are highly bituminous and stained on fracture faces with a deep reddish-brown color. They are filled with impressions of Inoceramus shells and contain several beds of fine-grained impure limestone that is impregnated on fractures with tar and smells strongly of petroleum. The amount of free tarry matter in the limestone beds at this locality is greater than that seen at any other place in this area. Author's text condensed.

Thom, W. T., 1923, The Sport Creek anticline, in Oil and gas prospects in and near the Crow Indian Reservation, Montana: U.S. Geol. Survey Bull. 736-B, p. 35-53 [p. 50].

The Sport Creek anticline extends from the south-central part of sec. 4, T. 9 S., R. 33 E., to the central part of sec. 30 , T. 9 S., R. 34 E. The Chugwater red beds cover the crest of the fold, and the Tensleep sandstone is exposed in the banks of Little Horn River. The Tensleep is strongly impregnated with oil residues at this exposure. 


\title{
NEW MEXICO
}

\author{
Subject Index
}

Analyses

Cretaceous

Hail, W. J., Jr., 1957

Mesaverde Formation

McKinley County

Ball, M. W., 1951

Dakota Formation

Regional

Winchester, D. E., 1933

Ball Associates, Ltd., 1965

Ball, M. W., 1951

Gorman, J. M., and Robeck, R. C., 1946

Winchester, D. E., 1933

Reserves

Ball, M. W., 1951

Bates, R. L., 1942

Gorman, J. M., and Robeck, R. C., 1946

Winchester, D. E., 1933

Triassic

Ball, M. W., 1951

Bates, R. L., 1942

Gorman, J. M., and Robeck, R. C., 1946

Hail, W. J., Jr., 1957

Winchester, D. E., 1933

Author List

Ball Associates, Ltd., compiler, 1965, New Mexico, in Surface and shallow oil-impregnated rocks and shallow oil fields in the United States: U.S. Bur. Mines Mon. 12, p. 198-204.

Three confirmed petroleum-impregnated outcrops are known in the north half of New Mexico. The largest, the Santa Rosa asphaltic sandstone deposits of Guadalupe County, is a known commercial reserve. The other two deposits are of minor importance.

Ball, M. W., 1951, Report on oil-impregnated strippable deposits in New Mexico as of May 22, 1950, Appendix C, in The synthetic liquid-fuel potential of New Mexico: U.S. Army Corps of Engineers, Summary report for the U.S. Bureau of Mines, Department of the Interior: Ford, Bacon \& Davis, Inc., Engineers.

Bituminous deposits are known in two counties in New Mexico. A deposit of lenticular shaly bituminous sandstone lenses occurs in McKinley County, approximately 20 miles northeast of Gallup. The deposit is in the Upper Cretaceous Mesaverde formation. Guadalupe County contains New Mexico's only known reserves. Reserves, as defined in this report, contain at least 10 million tons in a 5-square-mile area in vertically continuous series of beds at least 15 feet thick, with an overburden not exceeding the thickness of the beds and an oil content of at least 10 gallons per ton. The bituminous sand 
deposits lie within an area of about 10 square miles, 10 miles north of Santa Rosa. The asphalt is in the upper sandstone member of the Triassic Santa Rosa formation. The asphalt is a residual product derived from oil that probably originated in the limestone member of the San Andres formation. The oil probably migrated upward into the Santa Rosa sandstone through sinkholes and similar conduits. Core analysis and other geological evidence suggest the presence of about 233.6 million tons recoverable reserves. Bitumen content is estimated to be 10 gallons per ton. Author's text condensed.

Bates, R. L., 1942, The oil and gas resources of New Mexico [2d ed.]: New Mexico Bur. Mines and Mineral Resources Bull. 18, 320 p.

In eastern San Miguel County and in Guadalupe County, New Mexico, the Santa Rosa sandstone (Triassic) is saturated with asphaltic oil at its type locality. The saturated sand is a well-consolidated crossbedded rock composed of sharp quartz grains and containing 4-8 percent of bituminous substance. Extracted fresh rock yields a very ductile asphalt that has a penetration of approximately 230 at $77^{\circ} \mathrm{F}$. It is estimated that this deposit of bituminous sandstone contains approximately 2 million tons having a residual asphalt content of 5 percent.

Gorman, J. M., and Robeck, R. C., 1946, Geology and asphalt deposits of north-central Guadalupe County, New Mexico: U.S. Geol. Survey Oil and Gas Inv. Prelim. Map 44.

Asphalt deposits occur in parts of the Preston, Beck, and José Perea grants, 10 miles north of Santa Rosa, within an area of about 14 square miles. The part of Guadalupe County containing the asphalt deposits lies within the high plains and is characterized by karst topography that has been developing intermittently since Triassic time. The asphalt is found in the Santa Rosa sandstone of Triassic age. In the area of the asphalt deposits, the shale member of the Santa Rosa sandstone is absent, and the underlying lower sandstone member is either absent or extremely thin. The upper and middle sandstone members, on the other hand, have thickened and become similar lithologically. The asphalt-impregnated sandstone is irregularly bedded and consists of subangular to subrounded, fine and medium quartz grains, with scattered flakes of mica. The asphalt is a residual product derived from oil that probably originated in the limestone member of the San Andres formation. The oil is believed to have migrated upward to the Santa Rosa formation through sinkholes and similar conduits resulting from solution. Areal distribution of the asphalt appears to have been controlled both by positions of the conduits and by local variations in the lithology of the Santa Rosa sandstone. Total reserves of all classes are over 102 million tons. Authors' text condensed.

Hail, W. J., Jr., 1957, New Mexico, in Reconnaissance for uranium in asphaltbearing rocks, Western United States: U.S. Geol. Survey Bull. 1046-E, p. 55-85 [p. 71].

Beds of asphalt-bearing sandstone in the Santa Rosa sandstone of Triassic age crop out in northern Guadalupe County at the abandoned quarries of the New Mexico Construction Co., about 10 miles north of Santa Rosa. The asphalt occurs in the upper and middle sandstone members of the Santa Rosa sandstone. The beds of asphalt-bearing sandstone range in thickness from 
4 to 41 feet in quarry exposures and are 100 feet thick in a core hole. Analyses of samples from the Santa Rosa area range from 0.002 to 0.052 percent uranium in the ash of the extracted oil. Author's text condensed.

Winchester, D. E., 1933, Bituminous sandstone, in Oil and gas resources of New Mexico: New Mexico Bur. Mines and Mineral Resources Bull. 9, 223 p. [p. 208-209].

The Santa Rosa sandstone (Triassic) in Guadalupe County near Santa Rosa is saturated with bituminous material over a considerable area. Drill holes have proved a saturated zone 10-60 feet thick. The saturated sand is a well-consolidated crossbedded rock composed of sharp quartz grains and containing from 4 to 8 percent of bituminous substance. Some parts of the sand are found to be completely saturated with asphaltic material, whereas other parts contain no asphalt. Extracted fresh material yields a very ductile asphalt which has a penetration of approximately 230 at $77^{\circ} \mathrm{F}$. Developments to date show the Santa Rosa deposit contains 2 million tons of bituminous sand having a residual asphalt content of 5 percent. Approximately 20 miles northeast of Gallup on the North Fork Rio Puerco, a sandstone reported to belong to the Dakota formation (Cretaceous) is saturated with a paraffinbase oil over a relatively large area. The saturated sandstone has a thickness of not more than 40 feet. The sand is coarse grained and hard. Analysis of the sand shows an oil content of as much as 24 percent. Author's text condensed.

\section{NEW YORK}

\section{Author List}

Ball Associates, Ltd., compiler, 1965, New York, in Surface and shallow oilimpregnated rocks and shallow oil fields in the United States: U.S. Bur. Mines Mon. 12, p. 206-210.

The few outcrops of oil-impregnated rocks are confined to the extreme western part of New York. The first known commercial use of petroleum in North America was that by the Seneca Indians, who gathered oil from a seepage near Cuba, 9 miles west of the Rockville oil-sand outcrop. Other known seepages are in Seneca and Cattaraugus Counties. The only known oil field producing from a depth less than 500 feet is the Browning field in Allegany County. It is partly abandoned. Author's summary condensed.

OHIO

Subject Index

Carboniferous

Berea sandstone

Pickaway County

Ball Associates, Ltd., 1965

Devonian

Columbus Formation

Delaware County

Ball Associates, Ltd., 1965

Origin

Orton, Edward, 1888 
Resources

Regional

Ball, M. W., 1951

Ball, M. W., 1951

Silurian

Orton, Edward, 1888

Rogers, J. K., 1936

\section{Author List}

Ball Associates, Ltd., compiler, 1965, Ohio, in Surface and shallow oil-impregnated rocks and shallow oil fields in the United States: U.S. Bur. Mines Mon. 12, p. 211-226.

Oil-impregnated rocks are known in 10 western Ohio counties in three general areas. The northwest area includes Paulding, Putnam, Wyandot, Allen, and Auglaize Counties. The southwest area includes Fayette, Highland, and Adams Counties; the largest bituminous deposit in Ohio is in the Brick School area in Highland County. Central Ohio has two known asphalt deposits. One is a saturated Mississippian Berea Sandstone at Ringold, in Pickaway County; this sandstone is not confirmed as an oil-impregnated outcrop. The other, at Bellepoint, in Delaware County, is a minor occurrence in the dolomite of the Devonian Columbus Formation. Author's text condensed.

Ball, M. W., 1951, Report on oil-impregnated strippable deposits in Ohio as of May 22, 1950, Appendix C, in The synthetic liquid-fuel potential of Ohio: U.S. Army Corps of Engineers, Summary report for the U.S. Bureau of Mines, Department of the Interior: Ford, Bacon \& Davis, Inc., Engineers.

Surface and near-surface deposits of oil-impregnated rock are known in southeastern Ohio in Morgan and Washington Counties, in northeastern Ohio in Trumbull County, and in southwestern Ohio in Highland County. In Morgan, Washington, and Trumbull Counties, oil has accumulated in sandstones near the surface in volumes sufficient to form small oil fields. In Highland County, a thin oil-impregnated bed of vuggy dolomite covers the surface over a small area. None of these deposits is of sufficient richness, thickness, and total quantity to meet the minimum reserve requirements, which require at least 10 millions tons of deposits in any 5-square-mile area, in vertically continuous beds at least 15 feet thick overlain by not more than their own thickness in overburden and yielding at least 10 gallons of oil per ton of deposit. Author's text condensed.

Orton, Edward, 1888, The origin and accumulation of petroleum and natural gas: Ohio State Geologist Rept., v. 6, p. 60-100.

The Waterlime (or lower Helderberg part of the Helderberg group) contains grains of asphalt in cavities in the rock and carbonaceous films that have had the same origin distributed through it. When struck with a hammer, it gives off a fetid odor of "limestone oil." Fossil corals are often partially occupied by this asphalt, and petroleum is sometimes found in small amounts. The Clinton limestone is petroliferous in almost all its outcrops. It yields oil where quarries have been opened in it, and springs that issue from it carry small amounts of oil. Small deposits have been found under convex surfaces of the Dayton limestone, just above the Clinton. Author's text condensed. 
Rogers, J. K., 1936, Geology of Highland County, Ohio: Ohio Div. Geol. Survey Bull. 38, 4th Ser., p. 131.

Asphaltic impregnations are common in the dolomites of the Lilley, Peebles, and Greenfield (Silurian) formations in many parts of Highland County, Ohio. The asphaltic rock is of economic value only in an area about 1 mile north of Hillsboro, extending nearly to Willettville. The richest rock occurs in the upper, porous part of the Lilley formation. Although this deposit has been known for many years, it had not been worked until about 1930 .

\section{OKLAHOMA}

Subject Index

Analyses

Hail, W. J., Jr., 1957

Shelley, P. G., 1929

Snider, L. C., 1913

Asphalt associated with ore deposits

Fowler, G. M., 1933

Siebenthal, C. E., 1915

Weidman, Samuel, 1932

Asphalt deposits

Dougherty deposit

Gorman, J. M., 1944

Grandone, Peter, and McHarg, R. E., 1951

Hail, W. J., Jr., 1957

Jordan, Louise, 1964

Täff, J. A., 1908a

Regional

Ball Associates, Ltd., 1965

Ball, M. W., 1951

Beach, J. O., 1945

Eldridge, G. H., 1901

Grandone, Peter, and McHarg, R. E., 1951

Hutchison, L. L., 1911

Jordan, Louise, 1964

Redfield, J. S., 1927

Shannon, C. W., and others, 1917

Shannon, C. W., and Trout, L. E., 1915

Snider, L. C., 1913

Stenzel, H. B., Fountain, H. C., and Hendricks, T. A., 1948

Taff, J. A., 1908a

Sulfur deposit

Ball Associates, Ltd., 1965

Beach, J. O., 1945

Gorman, J. M., Flint, G. M., Jr., Decker, C. E., and Ham, W. E., 1944

Jordan, Louise, 1964

Taff, J. A., 1908a

Counties with significant asphalt deposits

Atoka

Abraham, Herbert, 1945

Ardmore Geological Society, 1954

Beach, J. 0., 1945 
Counties with significant asphalt deposits - Continued

Atoka - Continued

Flawn, P. T., Goldstein, August, Jr., King, P. B., and Weaver, C. E., 1961

Honess, C. W., 1930

Bryan

Honess, C. W., 1930

Carter

Abraham, Herbert, 1945

Choctaw

Honess, C. W., 1930

Comanche

Abraham, Herbert, 1945

Delaware

Ireland, H. A., 1930

Garvin

Abraham, Herbert, 1945

Jefferson

Abraham, Herbert, 1945

Snider, L. C., 1913

Wegemann, C. H., 1916

Le Flore

Abraham, Herbert, 1945

Beach, J. O., 1945

Love

Abraham, Herbert, 1945

Bullard, F. M., 1925

Marshall

Abraham, Herbert, 1945

Mayes

Ireland, H. A., 1930

McCurtain

Abraham, Herbert, 1945

Davis, L. V., 1953

Davis, L. V., 1960

Honess, C. W., 1930

Murray

Abraham, Herbert, 1945

Gorman, J. M., 1944

Gorman, J. M., Flint, G. M., Jr., Decker, C. E., and Ham, W. E., 1944

Hutchison, L. L., 1911

Ottawa

Ireland, H. A., 1930

Pontotoc

Abraham, Herbert, 1945

Pushmataha

Beach, J. O., 1945

Honess, C. W., 1930

Stephens

Abraham, Herbert, 1945

Beach, J. O., 1945

Snider, L. C., 1913

Wegemann, C. H., 1916 
Cretaceous

Paluxy sand

Davis, L. V., 1953

Davis, L. V., 1960

Trinity Formation

Bullard, F. M., 1925

Shelley, P. G., 1929

Snider, L. C., 1913

Taff, J. A., and Reed, W. J., 1910

Oil seeps

Ardmore Geological Society, 1954

Fowler, G. M., 1933

Wegemann, C. H., and Howell, R. W., 1916

Ordovician

Simpson Group

Gorman, J. M., Flint, G. M., Jr., Decker, C. E., and Ham, W. E., 1944

Redfield, J. S., 1927

Reeds, C. A., 1910

Shelley, P. G., 1929

Taff, J. A., 1903

Production

Dale, Phyllis, and Beach, J. O., 1951

Regions or districts

Arbuckle Mountain Area

Ball Associates, Ltd., 1965

Eldridge, G. H., 1901

Redfield, J. S., 1927

Reeds, C. A., 1910

Snider, L. C., 1913

Stenzel, H. B., Fountain, H. C., and Hendricks, T. A., 1948

Ardmore Basin-Criner Hills-Marietta Basin area

Ball Associates, Ltd., 1965

Bullard, F. M., 1925

Eldridge, G. H., 1901

Snider, L. C., 1913

Brunswick district

Eldridge, G. H., 1901

Gorman, J. M., 1944

Buckhorn district

Eldridge, G. H., 1901

Gorman, J. M., Flint, G. M., Jr., Decker, C. E., and Ham, W. E., 1944

Ouachita Mountain area

Ball Associates, Ltd., 1965

Eldridge, G. H., 1901

Flawn, P. T., Goldstein, August, Jr., King, P. B., and Weaver, C. E., 1961

Ham, W. E., 1956

Hendricks, T. A., Gardner, L. S., Knechtel, M. M., and Averitt, Paul, 1947

Howell, J. V., and Lyons, P. L., 1959

Snider, L. C., 1913 
Regions or districts - Continued

Wichita Mountain area

Ball Associates, Ltd., 1965

Snider, L. C., 1913

Stenzel, H. B., Fountain, A. C., and Hendricks, T. A., 1948

Wegemann, C. H., and Howell, R. W., 1916

Vein deposits

Abraham, Herbert, 1945

Beach, J. O., 1945

Eldridge, G. H., 1901

Hendricks, T. A., Gardner, L. S., Knechtel, M. M., and Averitt, Paul, 1947

Honess, C. W., 1930

Horn, W. E., 1956

Redfield, J. S., 1927

Snider, L. C., 1913

Stenzel, H. B., Fountain, H. C., and Hendricks, T. A., 1948

Taff, J. A., 1904

Taff, J. A., 1908a

Taff, J. A., 1908b

Wegemann, C. H., 1916

\section{Author List}

Abraham, Herbert, 1945, Oklahoma asphalts, in Asphalt and allied substances, v. 1 [5th ed.]: New York, D. Van Nostrand Co., 888 p. [p. 173-180, 273-278].

Oklahoma is one of the richest asphalt-bearing centers in the United States. Asphalts in both liquid and solid forms occur as springs, seepages, and rock impregnations. Nearly all the deposits are in the southern part of the State between the 35th parallel of north latitude and the Red River, and from the Arkansas line on the east to Granite, Okla. This area includes deposits or prospects in the following counties: Comanche, Jefferson, Stephens, Garvin, Carter, Murray, Love, Marshall, Johnston, Pontotoc, Atoka, McCurtain, and Leflore. This report includes a table showing location and quality of prospects in Oklahoma in 1945. The largest known grahamite vein in the world occurs in Jackfork Valley, 12 miles west of Tushkahoma. The vein is about 1 mile long and ranges in thickness from 19 to 25 feet. A cross section of this vein is included.

Ardmore Geological Society, 1954, Southern part of the Oklahoma coal basin: Ardmore Geol. Soc. Field Trip Guidebook, 29 p. [p. 8].

The Redden oil field was discovered in 1915. About 15 wells have been drilled, ranging in depth from 90 to 350 feet. At present, three wells are pumping an average total of nine barrels of $36^{\circ}$ gravity oil per day from about 105 feet deep. The producing zone is a bed of Stanley sand dipping about $60^{\circ} \mathrm{SE}$. Asphalt and other nonvolatile residues seem to have sealed the surface exposure, thus deterring the escape of the live oil below. Several other small oil fields and many oil seeps, asphaltic sands, and so forth, occur between the Windingstair and the Jackfork Mountain faults between the Redden field and the Arkansas border 115 miles to the east. Author's text condensed. 
Ball Associates, Ltd., compiler, 1965, Oklahoma, in Surface and shallow oilimpregnated rocks and shallow oil fields in the United States: U.S. Bur. Mines Mon. 12, p. 227-290.

Petroleum-impregnated rocks at or near the surface are known in 21 Oklahoma counties. The Wichita Mountain area includes Caddo, Comanche, Cotton, Greer, and Kiowa Counties. The petroliferous sandstones are mainly Permian in age. The Ardmore Basin-Criner Hills-Marietta Basin area includes Carter, Garvin, Jefferson, Love, and Stephens Counties. The petroleumimpregnated sandstones here are Ordovician through Early Cretaceous in age. The Arbuckle Mountain area includes parts of Johnston, Murray, and Pontotoc Counties. Ordovician sandstones and limestones and Pennsylvanian and Cretaceous sandstones are asphaltic here. The most important asphaltic rocks in Oklahoma are in Murray County. Natural asphaltic rock was first produced in Oklahoma in 1891 from rich outcrops near Sulphur, in Murray County. Approximately 3 million tons of asphaltic rock has been produced commercially from the State, used mainly for paving. Author's summary condensed.

Ball, M. W., 1951, Report on oil-impregnated strippable deposits in Oklahoma as of May 22, 1950, Appendix C, in The synthetic liquid-fuel potential of Oklahoma: U.S. Army Corps of Engineers, Summary report for the U.S. Bureau of Mines, Department of the Interior: Ford, Bacon \& Davis, Inc., Engineers.

Surface or near-surface oil-impregnated limestones and sandstones are known in 13 counties in the southern third of Oklahoma, south of the Canadian River. The deposits occur in sedimentary rocks ranging in age from Ordovician to Cretaceous. Information on most of the deposits is meager and incomplete. The available information reveals no reserves - that is, a 10million-ton deposit in any 5-square-mile area, in vertically continuous beds 15 feet thick yielding 10 gallons of oil per ton of raw material, and overlain by no more than its own thickness in overburden. Author's text condensed.

Beach, J. O., 1945, Oklahoma asphaltite deposits: The Hopper, v. 5, no. 6, 10 p.

Two varieties of solid, relatively pure hydrocarbons are known in Oklahoma. The most abundant variety is grahamite (an asphaltite); the other is impsonite (a pyrobitumen). These materials occur in veins and are regarded as having been formed as an alteration product of petroleum. The ash of the impsonite contains vanadium equivalent to 12.2 percent vanadium oxide $\left(\mathrm{V}_{2} \mathrm{O}_{\overline{3}}\right)$. This report contains locations and descriptions of the deposits in Atoka, Leflore, Murray, Pittsburg, Pushmataha, and Stephens Counties. An analysis of Oklahoma grahamite is also included. Author's text condensed.

Bullard, F. M., 1925, Geology of Love County, Oklahoma: Oklahoma Geol. Survey Bull. 33, 77 p. [p. 51-52].

Owing to its intensely folded rocks, the eastern part of Love County near the Criner Hills is not considered favorable for the production of oil or gas. Oil that was present in the Pennsylvanian rocks of this area has escaped in the form of gas, except for the heavier parts, which remain in the form of asphalt. Large deposits of asphalt occur in the Trinity (Cretaceous) sand adjacent to the Criner Hills. Author's text condensed. 
Dale, Phyllis, and Beach, J. O., 1951, Mineral production of Oklahoma 18851949: Oklahoma Geol. Survey Circ. 29, 38 p. [p. 12].

Gives production figures for asphalt from Oklahoma 1903-26.

Davis, L. V., 1953, Oil possibilities near Idabel, McCurtain County, Oklahoma: Oklahoma Geol. Survey Mineral Rept. 23, 26 p.

The discovery of oil in a well drilled for a farm water supply near Idabel, Okla., in December 1952 aroused interest in the oil possibilities of McCurtain County. All previous oil tests had been dry holes. This well discovered oil in the upper part of the Paluxy sand (Cretaceous) at a depth of 325 feet. Oil was bailed from the hole at irregular intervals for several days, and the total was estimated to be $35-40$ barrels. A test was then made in which the hole was first bailed dry, and, after a 50-minute interval, yielded 40 gallons of $28.6^{\circ}$ gravity black oil. The anomalous dips of the rocks of the Washita group along nearby Bokchito Creek indicate that oil accumulation is, to some extent, controlled by structure. Possibly the lensing of sand beds in the upper part of the Paluxy has helped trap the oil. Asphaltic sandstone occurs in sec. 20 , T. 7 S., R. 24 E., on the south side of the Little River. Asphaltic sandstone about 25 feet thick is exposed for a distance of about one-half mile. Another outcrop of asphaltic sandstone about 10 feet thick occurs in the $\mathrm{SE}^{1 / 4}$ sec. 22, T. 6 S.,. R. 21 E. Author's text condensed.

Davis, L. V., 1960, Geology and ground-water resources of southern McCurtain County, Oklahoma: Oklahoma Geol. Survey Bull. 86, 108 p. [p. 14].

About half a mile north of Valliant in McCurtain County, an asphaltic sand in the upper part of the Paluxy sand (Cretaceous) is exposed over an area of several acres. Spasmodic attempts to develop the deposit have been made since 1922, but none proved commercially successful. Oil was found near Idabel in 1952 in a 330-foot well drilled for water. The oil was at the top of the Paluxy sand, at a depth of about 325 feet below the surface. When a pump was installed, the yield quickly dropped, owing to the encroachment of the fine Paluxy sand. There has been further development of the area; most of the wells tapped oil in the fine sand at the top of the Paluxy, but because of difficulties in completing the wells, nearly all the wells have been abandoned. Author's text condensed.

Eldridge, G. H., 1901, Indian Territory, in Asphalt and bituminous rock deposits of the United States: U.S. Geol. Survey 22d Ann. Rept., pt. 1b, p. 209-452 [p. 262-320].

The area in Indian Territory (Oklahoma) where asphalt and bituminous rock deposits have been found lies between the Canadian and the Red Rivers and extends from Arkansas to the 98th meridian. The asphalt of eastern Indian Territory is of the vein-forming variety and is called impsonite. It occurs in Ordovician rocks in the Ouachita Mountains. Silurian to Cretaceous sandstones impregnated with bitumen occur in the Arbuckle Mountains, in the Criner Hills, in the Buckhorn district, and in the Brunswick district.

Flawn, P. T., Goldstein, August, Jr., King, P. B., and Weaver, C. E., 1961, The Ouachita System: Texas Univ. Pub. 6120, 401 p. [p. 192]. 
Oil has been produced from shallow wells in the Stanley sandstone near Redden, Atroka County, Okla. These wells, some of which were drilled as early as 1914, produce at a depth of 500 feet from steeply dipping tight sandstone sealed updip by asphalt impregnation. The oil at Redden may have migrated from some of the older, more petroliferous, underlying rocks that were faulted against the Stanley sandstone. There are many oil seeps and irregular bodies of grahamite or asphaltite within the Ouachita Mountains. Authors' text condensed.

Fowler, G. M., 1933, Oil and gas structures in Oklahoma-Kansas zinc-lead mining field: Am. Assoc. Petroleum Geologists Bull., v. 17, no. 2, p. 1436-1445.

The Oklahoma-Kansas field of the Tri-State zinc and lead mining district is unique in that some of its mines produce oil as well as zinc and lead ore. The oil is of a dark residual variety and comes from above the mine workings, which range in depth from 150 to 400 feet below the surface. The oil is considered to be a nuisance in both mining and milling operations. In a few mines the oil is sufficiently plentiful to be collected in sumps and sold locally for roofing purposes. The oil drips from the roof and sides of the mines, having worked its way downward through fissures and shattered zones from the original oil reservoirs, which were directly under the Pennsylvanian shale. The geologic structure controls the localization of the oil accumulations, as well as the ore. The mining operations destroyed a few oil seepages that were surface phenomena in this area. The largest was within the present townsite of Cardin, Okla., on the banks of Tar Creek. Other springs were found along this stream, which flows south through the field. Author's text condensed.

Gorman, J. M., 1944, Geologic map of the Dougherty asphalt area, Murray County, Oklahoma: U.S. Geol. Survey Oil and Gas Inv. Prelim. Map 15, with text.

The Dougherty asphalt area, also known as the Brunswick district, is in southern Murray County, Okla., about 3 miles southwest of the Sulphur asphalt area. The asphalt deposits are confined to the Viola (Ordovician) limestone and are closely associated with faults, particularly where the limestone is highly jointed. The suggestion is very strong that the asphalt ascended from the underlying Simpson group, along fault and fracture planes, and penetrated the Viola limestone along joints. Many of the joints are now filled with viscous asphalt, which "bleeds" during warm weather. The asphalt content of most of the rock ranges from 3.0 to 3.5 percent. Author's text condensed.

Gorman, J. M., Flint, G. M., Jr., Decker, C. E., and Ham, W. E., 1944, Geologic map of the Sulphur asphalt area, Murray County, Okla.: U.S. Geol. Survey Oil and Gas Inv. Prelim. Map 22, with text.

The Sulphur asphalt deposit, also known as the Buckhorn district, covers about 1 square mile in southern Murray County. The asphalt in the Sulphur area is found mainly in sandstone beds in the Simpson group of Ordovician age, although there are a few small deposits in the limestone member of the Bromide formation (Simpson group) and in the overlying Viola limestone, also of Ordovician age. The asphalt-impregnated parts of the sandstone are cohesive and semiplastic, and, except for a few places where the sand grains 
are partially cemented by calcium carbonate, the asphalt is readily separated from the sand grains by washing with hot water. The highest asphalt content and the most uniform asphalt are in the sandstone member of the Oil Creek formation of the Simpson group in and near the Griffith, Kirby, and Barnes pits, and Pit No. 80. These workings are divided into two groups that lie on opposite sides of the Central fault block of the limestone member of the Oil Creek formation. This suggests either that the border faults acted as conduits for the upward movement of liquid petroleum or that the deposits are devolatilized remnants of a former anticlinal oil field, part of which has been brought to the surface by faulting. The asphaltic limestone in this area contains 6 to 12 percent bitumen and averages 7 to 8 percent. Authors' text condensed.

Grandone, Peter, and McHarg, R. E., 1951, Preliminary report on oil, gas, and asphalt in Oklahoma: U.S. Bur. Mines, Minerals, and Geology Work Group Rept. for the Arkansas-White-Red Basins Inter-Agency Committee, $22 \mathrm{p}$.

Asphalt deposits occur widely in southeast Oklahoma in an area extending from Leflore County to as far west as Comanche County. The most important deposit being worked is near Dougherty, in Murray County. The material occurs as impregnated sandstone and limestone and is quarried from pits as rock asphalt and processed for road-surfacing material. According to a report by the Oklahoma Relief Administration, the deposits of asphalt in Oklahoma have been estimated to range from 2 to 13 million short tons. Authors' text condensed.

Hail, W. J., Jr., 1957, Oklahoma, in Reconnaissance for uranium in asphaltbearing rocks, Western United States: U.S. Geol. Survey Bull. 1046-E, p. 55-85 [p. 72-73].

The 17 asphalt deposits examined in Oklahoma occur in Ordovician, Pennsylvanian, and Permian rocks. One deposit occurs in limestone, the rest in quartzose sandstones. Only the Sulphur, Cameron, and Ada areas yielded samples containing appreciable amounts of uranium. Asphalt-bearing limestone from the Dougherty area is exceptionally low in uranium. Analyses of uranium in the ash of the extracted oil ranged from 0.001 to 0.22 percent. Author's text condensed.

Ham, W. E., 1956, Asphaltite in the Ouachita Mountains: Oklahoma Geol. Survey Mineral Rept. 30, 12 p.

The veins and fissure fillings of grahamite and impsonite that occur at 17 localities in southeastern Oklahoma are restricted to an east-trending belt, about 25 miles wide, in the thrust-faulted northern part of the Ouachita Mountains. They are between the Choctaw and Octavia faults, generally cutting shales and sandstones of the Stanley formation (Mississippian and Pennsylvanian). Most of the production is from the Sardis deposit, the largest known vein of grahamite in the world, and from the Jumbo mine. Impsonite is produced near Page for its high vanadium content in its ash. Author's abstract condensed.

Hendricks, T. A., Gardner, L. S., Knechtel, M. M., and Averitt, Paul, 1947, Geology of the western part of the Ouachita Mountains in Oklahoma: U.S. Geol. Survey Oil and Gas Inv. Prelim. Map 66, with text. 
Within the Ouachita Mountains, many oil seeps occur in steeply dipping sandstone beds in the Stanley shale. The most extensive seeps are in the Redden field, about 1 mile southeast of the village of Redden, where light oil has also been bailed from several wells less than 500 feet deep. Veins and irregular bodies of grahamite occur in steeply dipping beds and are believed to be derived from petroleum. The petroleum source beds are thought to be confined to strata of the rock facies characteristic of the Arbuckle Mountains and the McAlester coal basin. Authors' text condensed.

Honess, C. W., 1930, Geology of the Atoka, Pushmataha, McCurtain, Bryan, and Choctaw Counties, Oklahoma: Oklahoma Geol. Survey Bull. 40, v. 3, p. 96-103.

The asphalts of the counties listed above are of two general types - fissure veins and impregnated sandstones. The veins have resulted from (1) the solidification of liquid petroleum which welled up from beneath and for a time flowed from cracks in the ground, but which eventually ceased to flow, and (2) petroleum which remained in the cracks and near the surface and became hard. Locally, the crevasses were widened by the flow of asphalt and oil by as much as 50 feet, but in general these crevasses are 2-4 feet wide and gradually pinch out. Such veins may be 1 mile long, as is the Sardis vein in Pushmataha County, but any single continuous body of grahamite or gilsonite rarely extends more than 100-200 yards from the outcrop. All the known large veins are in the Stanley formation (Mississippian). The Jumbo and Sardis veins are typical fissure veins. The asphaltites, or impregnated sandstones, occur most conspicuously in the valley of McGee Creek near Redden, where ledges of sandstone, 4-6 feet thick and saturated with asphalt, come to the surface at angles up to $45^{\circ}$. At a depth of 600 feet, these sandstones contain fluid oil, which indicates that the present dried-out exposed edges of the sand bodies formerly exuded petroleum. The Stanley sandstones and shales contain the asphaltites in addition to the grahamite and gilsonite veins. Author's text condensed.

Howell, J. V., and Lyons, P. L., 1959, Oil and gas possibilities of the Ouachita Province, in The geology of the Ouachita Mountains - A symposium: Dallas Geol. Soc. and Ardmore Geol. Soc. Field Trip Guidebook, p. 57-60.

A table in this report lists the asphalt deposits in the Ouachita Mountains, giving the locality, the nature of the deposits, and the formation in which they occur.

Hutchison, L. L., 1911, Preliminary report on the rock asphalt, asphaltite, petroleum, and natural gas in Oklahoma, Pt. I: Oklahoma Geol. Survey Bull. 2, p. 1-93.

This report gives a detailed description of each asphalt deposit known in Oklahoma in 1911.

Ireland, H. A., 1930, Mayes, Delaware, and Ottawa Counties: Oklahoma Geol. Survey Bull. 40, v. 3, 663 p. [p. 499].

Asphalt accumulates on the floor of lead and zinc mines near Picher, Okla. The asphalt drips down from fissures and through core-drill holes. These deposits occur only where the surface rock is Cherokee shale. Also, the 
deposits, though found in many places, occur in large quantities in only a few localities. In one location the asphalt accumulates at the rate of 35-50 barrels per month. This material is used to make a high-grade roofing compound. Asphalt accumulation is due both to gravity and seepage and to the fact that the ground water has been drained away by the mine stopes. It comes from a residue of evaporated and naturally distilled petroleum. Tar Spring on Tar Creek, 6 miles north of Miami, is so named because of the heavy bitumen accumulation at the base of the Cherokee shale. Author's text condensed.

Jordan, Louise, 1964, Petroleum-impregnated rocks and asphaltite deposits of Oklahoma: Oklahoma Geol. Survey Map GM-8, 16 p.

Petroleum-impregnated rocks and asphaltite deposits at the surface and to a depth of 500 feet have been found in 33 of the 77 counties in Oklahoma. These rocks include sandstone and limestone containing asphalt at or near the surface and those containing crude oil near the surface. Since 1926 most of the Oklahoma production has come from the deposits near Sulphur and Dougherty. A few quarries were worked through 1960. Oklahoma has produced approximately 3 million tons of asphaltic rock, which is used primarily as road-paving material. Seepages, crude oil in wells drilled for water, and areas of oil production at depths less than 500 feet are described in this report, and their locations are shown on the accompanying map. Author's text condensed.

Redfield, J. S., 1927, Mineral resources in Oklahoma: Oklahoma Geol. Survey Bull. 42, 130 p. [p. 89-91].

Asphalt occurs widely in southern Oklahoma in rocks of different ages. In the Arbuckle Mountains, the deposits are in the Simpson and Viola formations of Ordovician age. Deposits of commercial value are known at various localities in the Trinity sand (Comanchean age) of the Red River area. Several deposits of pure asphalt are known in the Ouachita Mountain region of southeastern Oklahoma: one deposit, known as the Jumbo mine, is northwest of Antlers; another is near Tuskahoma; and a third is near Page. The asphalt occurs as veins which probably formed along fault planes. Material in the Jumbo deposit has a glassy luster and a conchoidal fracture characteristic of anthracite coal, but it has much lower specific gravity than coal. The limestone and sandstone impregnated with asphalt have been used extensively for paving. The pure asphalts from the Ouachita Mountain region are too low in volatile constituents and, consequently, too brittle to be used for paving material. Such asphalt is used principally in the manufacture of asphalt varnishes, paints, and waterproofing and insulating materials. Author's text condensed.

Reeds, C. A., 1910, A report on the geological and mineral resources of the Arbuckle Mountains, Oklahoma: Oklahoma Geol. Survey Bull. 3, 69 p.

The asphalt deposits in and near the Arbuckle Mountains are very extensive, as indicated on the geologic maps accompanying this report. The asphalt is known locally as either "sand asphalt" or "lime asphalt." The sand asphalt occurs chiefly in the fine-grained Simpson sandstone (Ordovician) and the various Pennsylvanian sandstones surrounding the Arbuckle Mountains. The asphaltic limestone, less extensive than the asphaltic sandstone, occurs chiefly in the Viola limestone, which immediately overlies the Simpson formation. 
Judged from the character of the material and the nature of the outcrops, these deposits seem to have resulted from the slow natural evaporation of gas and oil.

Shannon, C. W., and others, 1917, A discussion of the oil and gas fields, and undeveloped areas of the State, by counties, Pt. II of Petroleum and natural gas in Oklahoma: Oklahoma Geol. Survey Bull. 19, 537 p., maps.

Part II of this report gives a detailed discussion of the oil and gas fields of each county, including untested and undeveloped parts of the State in 1917. The asphalt deposits are mentioned only briefly.

Shannon, C. W., and Trout, L. E., 1915, General information concerning oil and gas; geology of Oklahoma, Pt. I of Petroleum and natural gas in Oklahoma: Oklahoma Geol. Survey Bull. 19, 133 p.

Part I of this report deals with the oil and gas industry and discusses the geology of Oklahoma. The asphalt deposits are mentioned only briefly.

Shelley, P. G., 1929, Accelerated weathering properties of Oklahoma asphalts: Oklahoma Geol. Survey Circ. 19, 37 p.

The uses of asphalts include the manufacture of bituminized roofing material and all types of asphalt paints and protective coatings for the painting of steel, ship hulls, and so forth. These uses, as well as use for paving, require the greatest available weather-resistant qualities. After testing various Oklahoma asphalts, the author drew the following conclusions: (1) Light is the most effective weathering agent, and treatment with water seems to accelerate the deterioration effects of light; (2) Oklahoma asphalts weather in a different manner from the petroleum asphalt tested, but the general magnitude of deterioration is about the same; (3) asphalts from the Trinity sandstone show exceptionally good weather-resistant qualities; (4) asphalts from the Simpson formation show poorer weather-resistant qualities than do the natural (untreated) foreign asphalts; (5) the weathering of petroleum asphalt from a given source, similarly treated, is almost directly proportional to its hardness; however, (6) natural asphalts of Oklahoma show no relation between hardness and weathering properties.

Siebenthal, C. E., 1915, Origin of the zinc and lead deposits of the Joplin region, Missouri, Kansas, and Oklahoma: U.S. Geol. Survey Bull. 606, 283 p. [p. 16].

The lead and zinc deposits at Miami, Okla., are overlain by 40-220 feet of Pennsylvanian shale. In some places, the ore and the wallrocks contain much bitumen, and the mine waters are charged with hydrogen sulfide. The bitumen is interpreted to be the residue of an oil that has lost its lighter saturated hydrocarbons by fractionation in contact with shale. The fact that this residue was left at the base of the shale indicates that the lighter hydrocarbons escaped upward. The ore solutions cannot have been descending because the shale is impervious, and almost no surface water penetrates the mines. Thus, the mine waters, the bitumen, and the ore deposits all indicate ascending currents. Author's text condensed.

Snider, L. C., 1913, Rock asphalts of Oklahoma and their use in paving: Oklahoma Geol. Survey Circ. 5, 22 p. 
Most of Oklahoma's asphalt deposits occur in the southern third of the State. The asphalts of the Wichita Mountains occur near Lawton and consist of sandstones saturated with asphaltic bitumen. Jefferson and Stephens Counties contain considerable sandstone-asphalt deposits as much as 25 feet thick; in at least one locality, the asphalt appears to have worked up along a fault and to have impregnated the sandstone on both sides. In the Ardmore district the asphalts occur in the Glenn formation (Pennsylvanian). The rocks are folded, and the deposits of asphaltic sandstone generally dip very steeply in some places, almost vertically. There were at least 15 known deposits in this district in 1913. The Arbuckle Mountain district, which includes Murray, Johnston, and Pontotoc Counties, contains commercial deposits, principally in the Dougherty and Sulphur areas. In the Ouachita Mountain area, veins of pure asphalt are present, usually along faults. The asphalts of the Red River district occur principally in the Trinity sand (Lower. Cretaceous). The sands of the Trinity are mostly unconsolidated, except where they are cemented by bituminous materials. This report contains a comparison of Oklahoma rockasphalt pavements with sheet-asphalt pavements.

Stenzel, H. B., Fountain, H. C., and Hendricks, T. A., 1948, Asphalt and related bitumens, in Weissenborn, A. E., and Stenzel, H. B., eds., Geological resources of the Trinity River tributary area in Texas and Oklahoma: Texas Univ. Pub. 4824, 252 p. [p. 21-30].

The bituminous sand deposits in Texas occur in the Lower Cretaceous rocks in Cooke and Montague Counties, in the Permian rocks in Coke County, in the Pennsylvanian rocks in Stephens County, and as oil seeps from impregnated Eocene strata in Anderson and Nacogdoches Counties. In Oklahoma, asphalt occurs in the Permian beds, east of the Wichita Mountains, in Comanche County, and from Ordovician to Cretaceous strata on the north, west, and south flanks of the Arbuckle Mountains. Asphalt also occurs in the Cretaceous tar sands in Love, Marshall, Johnston, and McCurtain Counties and in the veinlike deposits of grahamite and impsonite, in the Ouachita Mountain area, in Stephens County. Asphalt was being mined, in Murray County, in the Arbuckle Mountain area in 1946. This report includes production data for 1934-46, analyses, and an index map showing the deposits. Editors' summary condensed.

Taff, J. A., 1903, Description of the Tishomingo quadrangle [Indian Territory; now Okla.]: U.S. Geol. Survey Geologic Atlas, Folio 98.

Asphaltic deposits of economic importance are found in the vicinity of Gilsonite, near the northwest corner of the Tishomingo quadrangle [in what is now nearly the center of Oklahoma]. These deposits occur mainly in Ordovician sandstone and limestone in and near the west end of the contorted and faulted Belton anticline. The bituminous sandstone occurs in the middle and upper members of the Simpson formation (Ordovician). The sand grains are held together by the interstitial bitumen. The richer rock contains 7-12 percent bitumen and grades outward into barren sand. Five deposits of this sandstone were being mined in 1903. The bituminous limestone of economic importance in the Tishomingo quadrangle is in the Viola formation (Upper Ordovician). Locally, the limestone has been crushed and jointed, producing thin fissures into which the bitumen has entered as veinlets. The better grade of bituminous limestone carries 5-6 percent bitumen. Author's text condensed. 
Taff, J. A., 1904, Description of the unleased segregated asphalt lands in the Chickasaw Nation, Indian Territory: 61st Cong., 2d Sess., Senate Doc. $390,14 \mathrm{p}$.

There are two classes of asphalt deposits in the Choctaw and Chickasaw Nations. The most extensive deposit is a bitumen or asphaltite that permeates porous sandstone, limestone, and conglomerate and, when extracted, has a semiliquid or viscous consistency. These deposits are considered to be exposed petroleum pools or exudations from such pools from which the lighter oils have escaped by near approach to the surface, leaving the heavyrasphaltum base. The second, less extensive class of asphalt deposits in the Choctaw and Chickasaw Nations is a solid asphalt that resembles high-grade coal. It fills fissures in the rock walls that range in width from a fraction of an inch to (rarely) 25 feet and that extend nearly vertically into the earth. These deposits are nearly free from foreign substances and can be mined in the same manner as coal. They closely resemble the hard asphaltites known as albertite and grahamite. Author's text condensed.

Taff, J. A., 1908a, Asphalt and bituminous rock: U.S. Geol. Survey mineral resources of the United States for 1907, Pt. 2, p. 723-730.

Extensive deposits of bituminous rock are found in Oklahoma. Flat-lying strata of bituminous sand occur in supposed Permian strata in eastern Stephens County, Jefferson County, and western Carter County. Notable deposits occur near Loco and Asphaltum. Asphaltic sandstones, more or less steeply inclined, occur in the Carboniferous rocks near Woodford, Ardmore, Buckhorn, and Fitzhugh. Large deposits of richly bituminous sandstone and limestone are found in the Ordovician rocks at Gilsonite and near Sulphur and Dougherty, in Murray County. A solid asphalt - grahamite - occurs at several localities as vertical veins in the highly folded Carboniferous sandstone and shale. The veins vary in width from stringers to bodies several feet thick. These grahamite deposits are characterized by perfect blackness, high luster, brittleness, and a high grade of purity. Grahamite is found in the following localities in Oklahoma: In western Pushmataha and eastern Atoka Counties northwest of Antlers; in Stephens County, near Loco; and east of Page, in Leflore County. Author's text condensed.

Taff, J. A., 1908b, Grahamite deposits of southeastern Oklahoma: U.S. Geol. Survey Bull. 380-H, p. 286-297.

The grahamite deposits of southeastern Oklahoma occur as veins that fill fissures in sandstone and shale, whose bedding varies in position from horizontal to highly folded or tilted. The rocks containing grahamite occur in Ordovician rocks and at several positions in Carboniferous sections. Variation in composition is evidently due to differences in degree of loss of the more volatile hydrocarbons; it is apparently unrelated to the age of the enclosing rocks. The grahamite veins, like any other vein deposit, are variable in extent. They vary in thickness in every direction and (or) terminate abruptly, for they occur in a region where both faulting and folding have continued since the introduction of bitumen into the fissures. The only deposits warranting development and that are being worked at present are those in Impson and Jackfork valleys. 
Taff, J. A., and Reed, W. J., 1910, The Madill oil pool, Oklahoma: U.S. Geol. Survey Bull. 381-D, p. 504-513.

The Trinity (Cretaceous) sand is known to contain petroleum or bitumen, a residue of crude petroleum at various localities in southwestern Arkansas, southern Oklahoma, and Texas. In southwestern Arkansas and northern Texas, as well as in southern Oklahoma, thick deposits of Carboniferous rocks that contain oil residue underlie the Trinity. Furthermore, the Carboniferous beds are tilted in such a way that their edges project against the base of the Trinity sand. Any oil in the Carboniferous strata beneath the Trinity would eventually be moved upward and would either lodge in that sand or find an exit through it to the surface. The oil of the Madill pool is believed to have had its source in the underlying Paleozoic strata. Authors' text condensed.

Wegemann, C. H., 1916, The Loco gas field, Stephens and Jefferson Counties, Oklahoma: U.S. Geol. Survey Bull. 621-C, p. 31-42.

The Loco gas field is on the line between Stephens and Jefferson Counties, Okla., about 3 miles southwest of the village of Loco. For many years asphalt deposits have been known to exist southwest of the town of Loco in Stephens County. The grahamite deposits 6 miles north of Loco were worked at one time and then abandoned. Oil and gas in the Loco field occur in small quantities in many of the Permian sandstone beds, but the principal gas-bearing zone consists of one or more beds of sandstone in the lowermost 250 feet of the Permian strata at depths of 650-750 feet. Author's text condensed.

Wegemann, C. H., and Howell, R. W., 1916, The Lawton oil and gas field, Oklahoma: U.S. Geol. Survey Bull. 621-G, p. 71-85.

This report contains a section titled "Asphalt Seeps and Occurrences of Oil and Gas in the Vicinity of the Wichita Mountains." It locates and describes about 36 asphalt seeps and showings of oil and gas in and near the Lawton field.

Weidman, Samuel, 1932, The Miami-Picher zinc-lead district, Oklahoma: Oklahoma Geol. Survey Bull. 56, 177 p. [p. 23, 68, 69, 134, 149].

Bitumen, known as "tar" by the miners, occurs in appreciable quantity in some of the mines of the Miami-Picher district. The source of the tar is very probably in the coal seams and in the oil-bearing parts of the Cherokee shale that overlies the ore-bearing rock of the district. Tar Springs on Tar Creek is now covered by debris from the mines in Cardin. Tar occurs in some mines in sufficient quantity to interfere with milling the ores. Bitumen-saturated ore must be roasted before being crushed and milled.

OREGON

\section{Author List}

Ball Associates, Ltd., compiler, 1965, Oregon, in Surface and shallow oilimpregnated rocks and shallow oil fields in the United States: U.S. Bur. Mines Mon. 12, p. 291-292.

Oil seeps, outcrops of solid bitumens, and asphaltic residues in vugs, seams, and veinlets are reported in widely scattered localities in Oregon. These occur 
in both volcanic and sedimentary rocks. Only one occurrence of oil-impregnated rock is known: a sandstone of the Miocene Payette Formation, saturated with light paraffinic petroleum, crops out in Sand Hollow, on the north plunge of the Double Mountain anticline, in Malheur County. Authors' summary condensed.

\section{PENNSYLVANIA}

\section{Author List}

Donohue, D. A. T., 1965, Simulation of oil recovery by steam injection from the Franklin "heavy-oil" field: Jour. Canadian Petroleum Technology, v. 4 , no. 4 , p. $219-226$.

The Franklin heavy-oil field, Venango County, Pa., was discovered in 1859, but is now virtually abandoned. The producing formation is the First Sand of the Upper Devonian Vanango Group. Because of thinning and cementation, only about half of the sand body, or potential reservoir area, is commercially productive. An estimated 66.75 million barrels of crude oil remains in place. The gravity of this oil is about $31^{\circ} \mathrm{API}$, and the crude is distinguished by its paraffinic base, naphthenic light ends, and good market value. Recently, it was announced that a steam-injection pilot test was to be initiated in this field. Using physical data and published mathematical models, the oil recovery by steam injection into one particular area of the Franklin heavy-oil field was simulated. For a radial system equivalent to a 0.721 -acre five-spot, a steam-injection rate of $2,000 \mathrm{lbs}$ per $\mathrm{hr}$, and a conformance factor of unity, 46.75 percent of the original oil in place should be recovered by the end of the first year. Author's text condensed.

\section{SOUTH DAKOTA}

\section{Author List}

Ball Associates, Ltd., compiler, 1965, South Dakota, in Surface and shallow oil-impregnated rocks and shallow oil fields in the United States: U.S. Bur. Mines Mon. 12, p. 295-296.

Oil-saturated sandstones in the Pennsylvanian Minnelusa Formation crop out in extreme western part of Lawrence County, near the Wyoming-South Dakota boundary, and reportedly near Sturgis, along the boundary between Lawrence and Meade Counties. Small oil-saturated patches are reported in the Fall River Sandstone (Upper Cretaceous) in Meade, Pennington, and Fall River Counties, although some question exists as to whether the patches are oil stain or limonite stain. Upper Cretaceous "Frontier" sands in Fall River County contain tarry material in minor amounts in a few outcrops. Author's summary condensed.

\section{TENNESSEE}

\section{Author List}

Ball Associates, Ltd., compiler, 1965, Tennessee, in Surface and shallow oilimpregnated rocks and shallow oil fields in the United States: U.S. Bur. Mines Mon. 12, p. 297-298. 
Tennessee has no confirmed oil-impregnated rocks on the surface, although oil seeps occur in the Ordovician rocks in Clay, Davidson, Fentress, Overton, and Pickett Counties; in the Silurian rocks in Lincoln County; and in the Mississippian rocks in Seward County. Formations underlying the black shale of the Devonian Chattanooga Formation are locally stained with a petroleum substance. Author's summary condensed.

Born, Kendall, 1936, Asphalt, in Summary of mineral resources of Tennessee: Tennessee Div. Geology Bull., 2d Ser., 102 p. [p. 41].

Asphalt has been observed and reported in a few places in Tennessee. In most localities the source of the asphaltic substance appears to be the black bituminous Chattanooga shale, although in some places the asphalt seems to have resulted from the natural distillation of crude oil in other formations. Asphaltic Silurian sandstones have been reported in Lincoln County near Coldwater. The formations underlying the black shales throughout middle Tennessee are commonly stained with an asphaltic substance derived from the underlying shale. Author's text condensed.

\section{TEXAS}

Subject Index

Analyses

Dumble, E. T., 1891

Hail, W. J., Jr., 1957

Schoch, E. P., 1916

Terry, W. M., 1942

Counties with significant asphalt deposits

Anderson

Ball, M. W., 1951

Burnet

Ball, M. W., 1951

Barnes, V. E., 1936

Eldridge, G. H., 1901

Coke

Beede, J. W., and Bentley, W. P., 1918

Jones, R. A., 1925

Cooke

Ball, M. W., 1951

Bybee, H. P., and Bullard, F. M., 1928

Phillips, W. B., 1902

Kinney

Ball Associates, Ltd., 1965

McLennon

Medina

Ball, M. W., 1951

Liddle, R. A., 1918

Montague

Ball, M. W., 1951

Eldridge, G. H., 1901

Phillips, W. B., 1902

Pecos

Ball, M. W., 1951 
Counties with significant asphalt deposits - Continued

Reeves

Ball, M. W., 1951

Tarrant

Ball, M. W., 1951

Uvalde

Ball Associates, Ltd., 1965

Ball, M. W., 1951

Corpus Christi Geological Society, 1965

Eldridge, G. H., 1901

Getzendaner, F. M., 1931

Gorman, J. M., and Robeck, R. C., 1945

Hazzard, R. T., 1956

Sellards, E. H., and Evans, G. L., 1946

Vaughn, T. W., 1897

Zavala

Ball, M. W., 1951

Getzendaner, F. M., 1931

Vaughn, T. W., 1897

Cretaceous

Eldridge, G. H., 1901

Hazzard, R. T., 1956

Anacacho limestone

Baker, C. L., 1928

Corpus Christi Geological Society, 1965

Gorman, J. M., and Robeck, R. C., 1945

Harvill, L. L., 1959

Liddle, R. A., 1918

Maxwell, R. A., 1962

Sellards, E. H., and Baker, C. L., 1934

Sellards, E. H., and Evans, G. L., 1946

Terry, W. M., 1942

Udden, J. A., Baker, C. L., and Bose, Emil, 1916

Utterback, D. D., 1954

Vaughn, T. W., 1900

Trinity formation

Barnes, V. E., 1936

Terry, W. M., 1942

Metamorphism

Baker, C. L., 1928

Vaughn, T. W., 1897

Mining and quarrying

Corpus Christi Geological Society, 1965

Getzendaner, F. M., 1931

Mills, Brad, 1935

Nacogdoches oil field

Mills, Brad, 1935

Youngmeyer, R. F., and Jindra, R. I., 1951

Origin

Baker, C. L., 1928

Harvill, L. L., 1959

Utterback, D. D., 1954 
Ozokerite

Regional

Schoch, E. P., 1916

Ball Associates, Ltd., 1965

Ball, M. W., 1951

Dumble, E. T., 1891

Eldridge, G. H., 1901

Phillips, W. B., 1902

Sellards, E. H., and Baker, C. L., 1934

Sellards, E. H., and Evans, G. L., 1946

Terry, W. M., 1942

Udden, J. A., Baker, C. L., and Bose, Emil, 1916

Vaughn, T. W., 1897

Resources

Ball Associates, Ltd., 1965

Ball, M. W., 1951

Barnes, V. E., 1936

Gorman, J. M., and Robeck, R. C., 1945

Sellards, E. H., and Baker, C. L., 1934

Tar seeps

Dumble, E. T., 1891

\section{Offshore}

Soley, J. C., 1910

Thermal recovery

Suderman, C. P., Jr., 1965

Uranium

Hail, W. J., Jr., 1957

Uvalde district

Ball Associates, Ltd., 1965

Corpus Christi Geological Society, 1965

Gorman, J. M., and Robeck, R. C., 1945

Maxwell, R. A., 1962

Vaughn, T. W., 1900

\section{Author List}

Baker, C. L., 1928, Possible distillation of oil from organic sediments by heat and other processes of igneous intrusions - asphalt in the Anacacho formation of Texas: Am. Assoc. Petroleum Geologists Bull., v. 12, no. 10, p. 995-1003.

Rock asphalt is present in great amount in the Anacacho limestone and is associated with many igneous intrusive rocks. The intrusives are either later than or contemporaneous with the oil-source strata and the asphalt-bearing rock. It is suggested that the oil was originally in bituminous shales older than the intrusive rocks and was distilled and caused to migrate to higher levels as a consequence of intrusive processes and effects. Certainly, large amounts of asphalt and tar now occur close to the igneous masses, which left intact a large quantity of the oil originally present in the invaded strata. Probable lack of a sufficient supply of oxygen may be the reason these gases are not consumed in the intense heat of active volcanism. Author's abstract condensed. 
Ball Associates, Ltd., compiler, 1965, Texas, in Surface and shallow oilimpregnated rocks and shallow oil fields in the United States: U.S. Bur. Mines Mon. 12, p. 299-320.

Oil-impregnated limestones and sandstones are found in a broad northeastsouthwest band of Cretaceous rock outcrops across the middle of the State. Seventeen areas are discussed in this report. The most important deposit is in the Uvalde district of southeastern Kinney County; there, asphaltic limestone is quarried for paving. The deposit is 63 to 124 feet thick, with 15 to 22 feet of overburden. The bitumen content is $15-17$ gallons per ton. Total "measured," "indicated," and "inferred" reserves were estimated in 1950 to be about 348 million tons. Author's summary condensed.

Ball, M. W., 1951, Report on oil-impregnated strippable deposits in Texas as of May 22, 1950, Appendix D, in The synthetic liquid-fuel potential of Texas: U.S. Army Corps of Engineers, Summary report for the U.S. Bureau of Mines, Department of the Interior: Ford, Bacon \& Davis, Inc., Engineers.

Oil-impregnated limestones and sandstones are found in or adjacent to the broad belt of Cretaceous rocks across the middle one-third of the State of Texas. Data are presented on deposits in the following counties: Anderson, Burnet, Cooke, McLennon, Montague, Pecos, Reeves, Tarrant, Uvalde, and Zavala. Only Uvalde County contains deposits of at least 10 million tons within 5 square miles, not less than 15 feet in continuous vertical thickness, yielding at least 10 gallons per ton, amenable to opencut mining by removal of overburden no greater than the thickness of the deposit. Reserves in Uvalde County amount to $347,650,000$ tons. Author's summary condensed.

Barnes, V. E., 1936, Report on asphalt deposits in Burnet County, Texas: Texas Univ. Bur. Econ. Geology Mineral Resource Survey Circ. 11, 4 p.

A deposit of asphalt in shelly limestone occurs on the eastern slope of Post Mountain, three-fourths mile west of Burnet. The asphalt is in two porous limestone layers, 15 feet apart stratigraphically in the Trinity rocks (Cretaceous). The upper bed is too thin to be of commercial value. An estimated 119,000 tons of asphaltic limestone is present in the lower bed. The only use for this deposit is as road material. Another asphalt deposit occurs just north of the Burnet city limits. Asphalt from it is used as a base for various medicinal preparations. This deposit is similar to the Post Mountain asphalt, and, as at that place, the asphalt occupies gastropod shell cavities and space between shells. The asphaltic layer averages less than 2 feet in thickness. The extent of the deposit and the asphalt content are unknown. Measured sections and pace-and-compass maps of each deposit accompany this report.

Beede, J. W., and Bentley, W. P., 1918, The geology of Coke County, Texas: Texas Univ. Pub. 1850, 82 p. [p. 77].

Coke County is unique in central Texas in having good showings of oil in surface sandstones. Some of these sandstones were the sands of delta channels on the margin of a shallow Permian sea. The presence of salt seeps and gypsum and anhydrite replacing dolomites indicates that the waters of this shallow sea were very concentrated. Oil presumably would not accumulate in such an environment, when marine life was scarce. It is yet to be demonstrated that commercial oil accumulations have been found which were in- 
digenous to this type of red beds. All known oil in commercial quantities in the red beds either is in a region of known faults or overlies highly inclined bituminous beds beneath an unconformity between the Permian and Pennsylvanian rocks from which the oil might have migrated, as occurred around the Wichita and Arbuckle Mountains. If these premises are true, it is unlikely that the Coke County oil showings originated in the beds in which they are found. Authors' text condensed.

Bybee, H. P., and Bullard, F. M., 1928, Geology of Cooke County, Texas: Texas Univ. Pub. 2710, p. 5-61 [p. 52].

The known asphalt deposits in Cooke County are limited to the western and northwestern parts of the county. The material is a sand asphalt at or near the top of the Trinity sand, frequently at the contact of the Trinity with the overlying Goodland limestone. The asphalt presumably came from the underlying Pennsylvanian rocks. Faulting permitted escape of the bituminous material, which collected or impregnated the sand immediately underneath the Goodland limestone. Just to the north of Cooke County, in Love County, Okla., numerous oil seeps and extensive asphalt deposits occur at this same stratigraphic horizon. Authors' text condensed.

Corpus Christi Geological Society, 1965, White's Uvalde mines, in Upper Cretaceous asphalt deposits of the Rio Grande embayment: Corpus Christi Geol. Soc. Ann. Field Trip Guidebook, Corpus Christi, Tex. 67 p.

Quarrying of the asphaltic Anacacho Limestone for road material has been carried on intermittently since 1891. White's Uvalde Mines Co. has been quarrying at this site for the past 15 years. The pit is 160 feet deep and extends to the base of the asphalt-bearing Anacacho Limestone. Weathered overburden averaging 18 feet in thickness overlies the deposit. Bitumen content ranges from 0 to 13 percent of the rock weight and averages approximately 8 percent. The rock is crushed, sized, and mixed to attain a bitumen content ranging from 5 to 9 percent, which is the optimum range to provide a good road surface. Information on the extent and thickness of the asphaltbearing Anacacho Limestone is fragmentary. As outcrops are commonly nonasphaltic, exploratory drilling is required to outline the asphaltic areas. Author's text condensed.

Dumble, E. T., 1891, Mineral resources of Texas in Report of the State Geologist for 1890: Texas Geol. Survey 2d Ann. Rept., 88 p. [p. xliii-xlv].

Tar springs are found in many places in the Tertiary and Cretaceous formations of Texas. In Uvalde County at several outcrops bitumen impregnates both sandstone and limestone. The sandstone contains an average of 14 percent asphalt. The asphaltic limestone is even richer - an average of three analyses shows 20.35 percent bitumen. Author's text condensed.

Eldridge, G. H., 1901, Texas asphalt deposits, in The asphalt and bituminous rock deposits in the United States: U.S. Geol. Survey 22d Ann. Rept., pt. 1 b, p. 320-327.

Bituminous rock deposits occur in Montague, Burnet, and Uvalde Counties in Texas. In Montague County the deposits occur in the Trinity sandstone. Two deposits were being mined near St. Jo in 1901. In Burnet and Uvalde Counties, the deposits occur in Cretaceous limestones. Rather extensive de- 
posits are present in the Anacacho Mountain region in the southwestern part of Uvalde County. There, the bitumen fills the interstitial spaces in the limestone and the larger cavities produced by the removal of molluscan remains. The amount of bitumen varies from 10 to 20 percent.

Getzendaner, F. M., 1931, Mineral resources of Texas, Uvalde and Zavala Counties: Texas Univ. Bur. Econ. Geology, Austin, Texas, p. 93-119.

Outcrops of rock asphalt occur across the entire southern part of Uvalde County. The most extensive and best known deposits, however, are in the vicinity of Turkey Creek and Little Muela Creek, in the southwestern part of the county, where three companies quarry, crush, and ship large quantities of this valuable paving rock. Both limestones and sandstones are impregnated by the asphalt, and they range stratigraphically from middle Anacacho to upper Escondido. The asphalt content of the rock is as high as 20 percent; material most suitable for paving purposes contains 10-12 percent asphaltum. In Zavala County a ledge of asphaltic sandstone crops out in the bed of the Nueces River near the north line of the county. It has never been utilized, although the asphalt content is as high as 20 percent. Author's text condensed.

Gorman, J. M., and Robeck, R. C., 1945, Asphalt deposits near Uvalde, Uvalde County, Texas: U.S. Geol. Survey open-file report, $10 \mathrm{p}$.

The asphalt deposits in the Uvalde district lie in southwestern Uvalde County and southeastern Kinney County, Tex. The principal deposits occur in the coquina beds of the Anacacho limestone of Late Cretaceous age. The minable reserves of asphaltic limestone in the area total 200 million cubic yards, averaging 8 percent bitumen by weight.

Hail, W. J., Jr., 1957, Texas, in Reconnaissance for uranium in asphaltbearing rocks, Western United States: U.S. Geol. Survey Bull. 1046-E, p. 55-85 [p. 72].

Large deposits of asphalt-bearing limestone in the Anacacho limestone of Late Cretaceous age crop out in an area of about 60 square miles in the vicinity of Blewett and the western part of Uvalde County. The uranium content of the asphalt is exceptionally low, ranging from 0.001 to 0.004 percent and averaging 0.002 percent in the ash of the extracted oil. Author's text condensed.

Harvill, L. L., 1959, Petrology of the Anacacho limestone of southwest Texas: Gulf Coast Assoc. Geol. Soc. Trans., v. 9, p. 161-165.

The Anacacho limestone is locally abundant in asphalt. A previous investigator (Utterback) concluded that the asphalt was deposited right along with the limestone, and argued that liquid petroleum generally originated in the reservoirs where it is now found. However, the present author's petrographic study shows that the bituminous material invaded the limestone, then shrank by loss of volatile constituents. This conclusion is based on the following evidence: (1) The pore space in the limestone is overwhelmingly of secondary origin; no truly primary porosity can be demonstrated; (2) the contact of asphaltic with asphalt-free rock cuts across bedding; and (3) the asphalt does not completely fill the pore spaces in the rock, but forms a coating on the limestone particles. Author's abstract condensed. 
Hazzard, R. T., 1956, Cretaceous rocks south of Tarpley to Del Rio, in Four Provinces Field Trip: San Angelo Geol. Soc. Field Trip Guidebook, pt. III, p. 43-72.

Outcrops of rock asphalt occur across the southern part of Uvalde County. The most extensive are near Turkey Creek and Little Muela Creek in the southwestern part of the county, where three companies quarry, crush, and ship large quantities of this valuable paving rock. The asphalt-impregnated rock is Cretaceous and occurs in the middle Anacacho to upper Escondido strata, and both limestone and sandstone are represented. Only the Anacacho limestone is being used at present. Asphaltum content in some places is as much as 20 percent, but the material most suitable for paving purposes contains 10-12 percent asphaltum. Author's text condensed.

Jones, R. A., 1925, An outcrop of surface oil sand in the Permian "red beds" of Coke County, west Texas: Am. Assoc. Petroleum Geologists Bull., v. 9, p. 1215-1216.

Surface sandstones saturated with petroleum are found at various localities in Coke County, Tex. The oil-bearing sandstone is in the fault and structural zone of Coke County, as described by Beede. The general opinion as expressed by Beede is that, because marine fossil remains are so rare in such formations, oil is not indigenous in red-bed sediments. However, the entire question of oil in red beds presents many unsolved aspects. Author's text condensed.

Liddle, R. A., 1918, The geology and mineral resources of Medina County, Texas: Texas Univ. Pub. 1860, 177 p. [p. 151-152].

Surface deposits of asphalt are known at two localities in Medina County; both are in the Anacacho limestone. In the bed of San Geronimo Creek onehalf mile southeast of Rio Medina, the Anacacho limestone contains considerable asphalt, although it is doubtful if the mineral is present in commercial quantities. On Seco Creek 2 miles north of D'Hanis, there is an asphalt seep approximately 100 feet long. The seep is bounded on the south by a fault. North of the fault the asphalt has ascended along the inclined strata and encountered the less pervious clays of the Escondido, which at this locality are downthrown against the Anacacho. Only 12 feet of the Anacacho directly underlying the Escondido is exposed on the north side of the fault. Author's text condensed.

Maxwell, R. A., 1962, Asphalt rock, in Mineral resources of South Texas: Texas Univ. Bur. Econ. Geology Rept. Inv. 43, p. 17-21.

Asphaltic Anacacho limestone crops out intermittently along a belt 60 miles long through Uvalde and Kinney Counties. The better known asphalt deposits are about 13-20 miles southwest of Uvalde. The Anacacho is a porous limestone composed mainly of broken shell fragments, and in some areas the pores contain asphalt residue. A history of operations in the Uvalde district is given in this report, and a mineral resource map is included. In 1945 Gorman and Robeck estimated the Uvalde district's reserves to be 200 million cubic yards. The asphalt deposits in the Sabinal area east of Uvalde have been known for 30 years, but they have not been thoroughly investigated. 
Mills, Brad, 1935, Nacogdoches oil mines: Oil Weekly, v. 79, no. 1, p. 27-30.

Oil mining in the Nacogdoches field, oldest producing district in Texas, may be a successful means of recovering oil that cannot be profitably produced by ordinary drilling methods. The sluggish nature of producing wells indicates the necessity of exposing a much larger surface of the producing formation to drainage than can be done by drilling and completing an ordinary well. This report gives detailed descriptions of two shafts that were dug in 1935 . Author's text condensed.

Phillips, W. B., 1902, Coal, lignite, and asphalt rocks: Texas Univ. Mineral Survey Bull. 3, 137 p. [p. 77-98].

Asphalt deposits occur near St. Jo in Montague and Cooke Counties, near Palestine in Anderson County, in southern Uvalde County, and near Burnet in Burnet County in rocks of Cretaceous to Tertiary age. A detailed description of each deposit and maps showing locations of deposits are included.

Schoch, E. P., 1916, Ozokerite from the Thrall oil field: Texas Univ. Pub. 66, p. 78-81.

Some dark-brown waxy material which is obtained with crude petroleum at Thrall, Tex., has recently been analyzed and has been recognized as being ozokerite of exceptionally good quality. It is very similar to paraffin except for its consistency. The Thrall ozokerite is "doughy" and can be "kneaded" whereas paraffin is flaky and brittle. Author's text condensed.

Sellards, E. H., and Baker, C. L., 1934, Asphalt rock, in The geology of Texas, v. 2: Texas Univ. Pub. 3401, p. 253-255.

The asphaltic limestone of the Anacacho formation of Late Cretaceous (Taylor) age is the largest body of bituminous limestone known. It extends for about 100 miles westward from the west line of Bexar County nearly to Spofford in Kinney County. The commercial worth of the Anacacho rock is enhanced because it can be prepared for paving merely by pulverizing and heating. The beds exploited in 1934 ranged in thickness from 10 to 50 feet and occurred in a syncline in close association with igneous rocks. The asphalt content ranged from 9 to 12 percent. The quarries are in the southwest corner of Uvalde County. The asphaltic sandstone of Montague and Cooke Counties lies at or near the top of the Trinity sand, just below the thin Goodland limestone. The asphalt was most likely derived from the underlying folded and faulted rocks which now seep oil on the south flank of the Arbuckle Mountains in Love County, Okla., and also farther north. The sandstone is impregnated with asphalt for an average thickness of 3 to 4 feet; the average content of asphalt in the rock is about 10 percent. Authors' text condensed.

Sellards, E. H., and Evans, G. L., 1946, Index to Texas mineral resources: Texas Univ. Bur. Econ. Geology Mineral Resource Survey Circ. 29, 24 p.

Natural asphaltic limestones occur in extensive deposits in the Cretaceous Anacacho formation in southwestern Uvalde County and in several small deposits in Lower Cretaceous strata near Burnet, in Burnet County. Large mining operations in Uvalde County produced asphaltic limestone for roadpaving material in 1946. Asphaltic sandstones not being utilized occur in Anderson, Cooke, Montague, Nacogdoches, Zavala, and several other counties. Authors' text condensed. 
Soley, J. C., 1910, The oil fields of the Gulf of Mexico: Sci. American Supp., v. 69 , p. 229.

The area in which floating oil has been found extends from lat $26^{\circ} \mathrm{N}$. to $28^{\circ} 30^{\prime} \mathrm{N}$., and from long $89^{\circ} \mathrm{W}$. to $93^{\circ} \mathrm{W}$. The most active part of the field is about 120 miles south of Trinity Shoal, off the Louisiana coast. Near the shore at Sabine Pass, there is a deposit of a viscid tarry liquid with a bituminous odor, which impregnates the mud. The oil probably occurs under water in a porous bed whose cover is sufficiently pervious to permit a constant slow seepage that saturates the overlying mud. A peculiar substance called sea wax is frequently found on the beaches between Sabine Pass and Matagorda. This sea wax is found in cakes as much as 6-8 feet long and 1-2 inches thick. This is undoubtedly a petroleum or asphaltum residuum, and its presence points to the existence of springs of liquid bitumen somewhere in the Gulf. Reports from vessels have located a seep at lat $27^{\circ} 30^{\prime} \mathrm{N}$. and long $91^{\circ} 30^{\prime} \mathrm{W}$, where oil was seen bubbling on the surface. The oil floats away from the source in large fields, but it absorbs oxygen from the air and evaporates quickly. The oil-and-water emulsion, mixing with water, first has the appearance of slime which is generally reported as discolored water, and later turns the water milky white; this appearance is often reported in the eastern part of the Gulf Current and as far south as the Florida Reefs. Author's text condensed.

Suderman, C. P., Jr., 1965, Thermal recovery activity in South Texas, in Upper Cretaceous asphalt deposits of the Rio Grande Embayment: Corpus Christi Geol. Soc. Annual Field Trip Guidebook, p. 33-36.

Several thermal-recovery techniques are commonly employed today: (1) in-situ combustion is based on setting the reservoir afire and sustaining combustion in the form of a moving fire-front through air injection; (2) steam or hot-water injection introduces heat to the reservoir without using any of the residual oil as fuel or contaminating the produced liquids with combustion gases; and (3) the steam-soak method utilizes the cyclic injection of steam into a reservoir followed by a period of production of the heated oil from the same well. The most successful thermal project in Texas to date is Texaco's in-situ combustion project at Charco Redondo field, Zapata County. This shallow field produced $17^{\circ}$ API oil from 15 feet of sand at an average depth of 160 feet. After 1 month of air injection, production from six wells increased to 3,300 barrels of oil, from the previous rate of 57 barrels. Cumulative production at the end of 24 months amounted to 60,000 barrels of oil, or about 23 percent of the estimated oil in place under the pilot area. This process has been tried in other shallow fields, but the Charco Redondo area is the only one where it has advanced beyond the pilot stage; it has yet to be proved economical. Author's text condensed.

Terry, W. M., 1942, The natural asphalts and asphalt rocks of Texas: Texas Univ. unpub. M.S. thesis, 68 p.

Nearly all the asphalt deposits in Texas occur in Cretaceous rocks. Only the deposits near Palestine, in Anderson County, occur in Eocene rocks. The most important deposit in Texas is near Uvalde, in Uvalde County, where bituminous impregnation of the Cretaceous Anacacho formation has occurred along a strip 15 miles long and 4-6 miles wide. Production of asphalt from this deposit was $600-800$ tons daily at the time this report was written. Samples 
from the Uvalde deposit contained from 4.82 to 13.35 percent bitumen. In the Burnet deposit; just north of the town of Burnet, the asphalt occurs in a layer about 1 foot thick at the top of a limestone ledge in the Glen Rose formation. The rock is a coquina; most of the shells are in the form of molds, and the asphalt occurs in the mold cavities. The bitumen in this deposit is soft, but hardens upon exposure. This deposit is probably a distillation residue of a former petroleum reservoir. Samples of this deposit range from 1.06 to 6.80 percent bitumen. The asphaltic sands near St. Jo, in Montague County, consist of a few feet of Trinity sand (Cretaceous) impregnated with asphaltic material. The asphalt layer crops out in the faces of cliffs, where blocks of the material break off and fall down the slope as talus. The impregnation has occurred irregularly, and in some places the rock is barren or only slightly stained by the bituminous material. Samples contained 2.1 to 12.5 percent bitumen. The asphalt deposit near Palestine occurs in the Queen City sand of middle Eocene age. This deposit consists of a subsurface reservoir of petroleum which has not yet reached the advanced stages of evaporation as have the Burnet and Uvalde deposits. The bitumen content of samples from this deposit averages 4.56 percent for unconsolidated material and 8.56 percent for consolidated material.

Udden, J. A., Baker, C. L., and Bose, Emil, 1916, Review of the geology of Texas: Texas Univ. Pub. 44, 146 p. [p. 141-142].

The only rock asphalt that has been utilized in Texas occurs in the Upper Cretaceous at Kline, in Uvalde County, and in the Trinity sands of the Commanchean in Montague County, north of St. Jo. The Kline asphalt occurs in the Anacacho limestone, a shell breccia; the porous space is filled partially or entirely by the asphalt, which is probably a residue from liquid bitumens that have escaped to the surface earlier. Asphalt also occurs in the Port Hudson clays at Sour Lake, Hardin County, and in small nodules of grahamite in the sands and sandy shales of the Eocene Jackson formation. Asphalt is widely distributed in the Trinity sands, occurring at many localities in the northern part of the State. Authors' text condensed.

Utterback, D. D., 1954, New questions on the origin of oil: Oil and Gas Jour., v. 53 , no. 16 , p. 121-124.

The author investigated surface outcrops of limestones and sandstones containing asphalt or heavy oil. His conclusions of the origin of the Uvalde deposits are as follows: (1) The bitumen in the Anacacho limestone was deposited contemporaneously with the material with which it is associated; (2) the rock is not an impregnated couqina, but consists of fragments of limestone in a bituminous matrix; and (3) it is not a residual oil pool; however, had the proper conditions prevailed, it might have been converted into an oil pool.

Vaughn, T. W., 1897, The asphalt deposits of western Texas: U.S. Geol. Survey 18th Ann. Rept., pt. 5, p. 930-935.

Asphalt-impregnated sandstone occurs at several localities along the Nueces River near the Uvalde-Zavala County line. The asphalt is in the Escondido formation, overlying the Anacacho limestone that contains the asphalt in the Uvalde and Sabinal areas. The most accessible outcrop is at Black Wax Falls, about 10 miles southwest of Uvalde, at a point where the Missouri Pacific 
Railway crosses the Nueces River. The highest concentration of asphalt is in a 5-foot-thick sandstone at the base of the falls. Samples collected from this sandstone show an asphaltic content of 14.2 percent. The region has been subjected to considerable igneous disturbance; there are laccolites, sills, and dikes of basalt. The asphalt occurs as accumulations in shallow synclinal basins and as impregnations of largely organic sedimentary rocks. The form of occurrence suggests that the heat of the basalt intrusions acted upon the organic limestones by driving out the asphalt or bitumen, which then accumulated in the synclinal basins as impregnations in the porous beds. Author's text condensed.

Vaughn, T. W., 1900, Description of the Uvalde quadrangle [Texas]: U.S. Geol. Survey Geol. Atlas, Folio 64.

Deposits of asphalt occur at two places within the Uvalde quadrangle. At one locality, on the east side of the Blanco River, near Sabinal, the asphalt has impregnated some porous layers of the Anacacho limestone. At the second, along the Nueces River, the asphalt occurs as an impregnation of a soft sandstone near the top of the Pulliam formation, the stratigraphically higher deposit. Structurally, this part of the Nueces Valley is a shallow syncline, and the asphalt occurs along the bottom of it. Author's text condensed.

Youngmeyer, R. F., and Jindra, R. I., 1951, Nacogdoches field, in Occurrence of oil and gas in northeast Texas: Texas Univ. Pub. 5116, p. 247-249.

The Nacogdoches field - the oldest in Texas - is approximately 15 miles southeast of Nacogdoches. As early as 1790 an oily substance found at the surface in this area was used to grease axles of wagons crossing over the Spanish trail. By 1890, 90 wells had been drilled to a depth of about 100 feet. The field produced intermittently until 1936, depending upon the price of oil. In 1935 two companies tried to mine the oil by digging shafts, but water was produced in such large quantities that the operations were abandoned. Authors' text condensed.

\section{UTAH}

Subject Index

Analyses

Bardwell, Carlos, Berryman, B. A., Brighton, T. B., and Kuhre, K. D., 1918

Hail, W. J., Jr., 1957

Asphalt deposits

Asphalt Ridge

Ball Associates, Ltd., 1965

Ball, M. W., 1951

Cashion, W. B., 1964

Cohenour, R. E., 1964

Covington, R. E., 1957

Covington, R. E., 1964a

Kayser, R. B., 1966

Pruitt, R. G., Jr., 1961a

Spieker, E. M., 1930 
Asphalt deposits - Continued

Circle Cliffs

Ball Associates, Ltd., 1965

Davidson, E. S., 1967

Ritzma, H. R., 1968a

Steed, R. H., 1954

Green River Desert-Cataract Canyon region

Baker, A. A., 1946

Mexican Hat oil field

Wengerd, S. A., 1955

Moab district

Baker, A. A., 1933

P. R. (Peor) Springs

Ball Associates, Ltd., 1965

Ball, M. W., 1951

Cohenour, R. E., 1964

Covington, R. E., 1964a

Regional

Ball Associates, Ltd., 1965

Ball, M. W., 1951

Cashion, W. B., 1964

Cohenour, R. E., 1964

Covington, R. E., 1963

Eldridge, G. H., 1901

Ritzma, H. R., 1967

Ritzma, H. R., 1968b

Ritzma, H. R., 1969

Rozel Point

Boutwell, J. H., 1905

Eardley, A. J., 1963

Eardley, A. J., and Haas, Merrill, 1936

Slentz, L. W., and Eardley, A. J., 1956

Sunnyside

Ball Associates, Ltd., 1965

Ball, M. W., 1951

Cashion, W. B., 1964

Cohenour, R. E., 1964

Covington, R. E., 1964a

Holmes, C. N., Page, B. M., and Averitt, Paul, 1948

Tar Sand Triangle

Bowman, J. L., 1969

Ritzma, H. R., 1968b

Temple Mountain

Breger, I. A., and Deul, M., 1959

Kelley, D. R., and Kerr, P. F., 1958

Robeck, R. C., 1954

Tenmile Wash

McKnight, E. T., 1940

Uinta Basin

Ball Associates, Ltd., 1965

Byrd, W. D., II, 1967

Cashion, W. B., 1967 


\section{ASPHALT-BEARING ROCKS, UNITED STATES AND CANADA}

Asphalt deposits - Continued

Uinta Basin - Continued

Covington, R. E., 1964a

Donnell, J. R., Culbertson, W. C., and Cashion, W. B., 1967

Hunt, J. M., 1963

Hunt, J. M., Stewart, Francis, and Dickey, P. A., 1954

Murray, A. N., 1950

Pruitt, R. G., Jr., 1961a

Ritzma, H. R., 1967

Winchester, D. E., 1919

Uinta River-Brush Creek area

Kinney, D. M., 1955

Whiterocks

Ball Associates, Ltd., 1965

Ball, M. W., 1951

Cohenour, R. E., 1964

Covington, R. E., 1964a

Kinney, D. M., and Rominger, J. E., 1947

Oil seeps

Baker, A. A., 1933

Baker, A. A., 1946

Boutwell, J. M., 1905

Gregory, H. E., and Moore, R. C., 1931

Miser, H. D., 1925

Permian

Cutler Formation

Bowman, J. L., 1969

Recovery methods

Covington, R. E., 1964b

Covington, R. E., 1965

Fene, W. J., 1928

Henderson, J. H., Jr., 1957

Kayser, R. B., 1966

Kilborn, G. R., 1964

Schick, R. B., 1966

Shea, G. G., and Higgins, R. V., 1952

Wenger, W. J., Hubbard, R. L., and Whisman, M. L., 1952

Resources

Ball Associates, Ltd., 1965

Bowman, J. L., 1969

Byrd, W. D., II, 1967

Cashion, W. B., 1964

Cohenour, R. E., 1964

Covington, R. E., 1963

Covington, R. E., 1964a

Holmes, C. N., Page, B. M., and Averitt, Paul, 1948

Pruitt, R. G., Jr., 1961a

Ritzma, H. R., 1969

Schick, R. B., 1966

Spieker, E. M., 1930

Untermann, G. E., and Untermann, B. R., 1964 
Tertiary

Bardwell, Carlos, Berryman, B. A., Brighton, T. B., and Kuhre, K. D., 1918

Green River Formation

Cashion, W. B., 1964

Cashion, W. B., 1967

Donnell, J. R., Culbertson, W. C., and Cashion, W. B., 1967

Wiley, D. R., 1967

Woodruff, E. G., and Day, D. T., 1915

Triassic

Moenkopi Formation

Bassler, Harvey, and Reeside, J. B., 1922

Bowman, J. L., 1969

Ritzma, H. R., 1968a

Ritzma, H. R., 1968b

Uranium

Breger, I. A., and Deul, M., 1959

Hail, W. J., Jr., 1957

Hess, F. L., 1922

Kelley, D. R., and Kerr, P. F., 1958

Robeck, R. C., 1954

Vein deposits

Baker, J. A., 1950

Bardwell, Carlos, Berryman, B. A., Brighton, T. B., and Kuhre, K. D., 1918

Bassler, Harvey, and Reeside, J. B., 1922

Carey, G. A., and Roberts, I. C., 1949

Cashion, W. B., 1964

Hunt, J. M., 1963

Hunt, J. M., Stewart, Francis, and Dickey, P. A., 1954

Gilsonite

Baker, J. A., 1950

Carey, G. A., and Roberts, I. C., 1949

Carman, E. P., and Bayes, F. S., 1961

Cashion, W. B., 1964

Cashion, W. B., 1967

Cashion, W. B., and Brown, J. H., Jr., 1956

Crawford, A. L., 1949

Crawford, A. L., 1957

Crawford, A. L., and Pruitt, R. G., 1963

Davis, L. J., 1957

Eldridge, G. H., 1901

Fene, W. J., 1928

Henderson, J. H., Jr., 1957

Kemmerer, J. L., 1934

Murray, A. N., 1950

Pruitt, R. G., Jr., 1961b

Untermann, G. E., and Untermann, B. R., 1964

Woodruff, E. G., and Day, D. T., 1915

Ozokerite

Cashion, W. B., 1964 
Vein deposits - Continued

Ozokerite - Continued

Crawford, A. L., 1953

Merrow, Joe, 1957

Robinson, H. M., 1917

Taff, J. A., and Smith, C. D., 1906

\section{Author List}

Baker, A. A., 1933, Geology and oil possibilities of the Moab district, Grand and San Juan Counties, Utah: U.S. Geol. Survey Bull. 841, 95 p.

Oil seeps are found in the Hermosa and Rico formations on the San Juan River about 100 miles south of Moab. In order to test these horizons, the first well was drilled in 1907. Oil was found at 225 feet. This well was a gusher, and spewed oil 70 feet above the floor of the derrick. Small production was obtained from several wells in the field, which continued to produce for many years. By 1933, however, there were no producing wells in the field. Author's text condensed.

Baker, A. A., 1946, Geology of the Green River Desert-Cataract Canyon region, Emery, Wayne, and Garfield Counties, Utah: U.S. Geol. Survey Bull. 951, 122 p.

Oil seeps or bituminous sandstone outcrops have caused southeastern Utah to be considered favorable territory for prospecting for oil and gas. Wells drilled to date (1946) have failed to find large accumulations of oil, but a few wells have yielded small quantities of oil and some gas, and many others have had shows of oil at one or more horizons.

Baker, J. A., 1950, Economics of gilsonite in the Uinta Basin, in Petroleum geology of the Uinta Basin: Utah Geol. Soc. Guidebook to the Geology of Utah, no. 5, p. 119-120.

Gilsonite has one feature which has caused considerable concern. In almost every instance where powder blasting has been used to break gilsonite loose from the solid state, explosive conditions exist, owing to the presence of gilsonite dust and pockets of methane gas, which occur in the vein. These combined features have caused explosions in most mines where powder was used for blasting. Therefore, most operations use the slope-mining method; miners pick the gilsonite free from the vein and allow it to roll to the bottom of the slope, where it can be collected, sacked, and hoisted to the surface. One of the larger producers is currently experimenting with opencut-slusher operations.

Ball Associates, Ltd., compiler, 1965, Utah, in Surface and shallow oil-impregnated rocks and shallow oil fields in the United States: U.S. Bur. Mines Mon. 12, p. 321-347.

Petroleum-impregnated outcrops are widespread throughout eastern Utah. In and around the edges of the Uinta Basin are some of the best known "tar sands" in the United States, including the Sunnyside, Asphalt Ridge, and Whiterocks deposits. Less well known, but probably of equal or greater importance, are widely distributed deposits in southeastern Utah, mainly along 
the flanks of breached anticlines, such as the San Rafael Swell and the Circle Cliffs uplift. Reserve figures are given for the Whiterocks, Asphalt Ridge, Sunnyside, and P. R. Springs deposits. These total 1,900 million to 4,600 million barrels of bitumen in place, substantially more than R. E. Covington's 1964 estimate. Author's text condensed.

Ball, M. W., 1951, Report on oil-impregnated strippable deposits in Utah as of May 22, 1950, Appendix $\mathrm{D}$, in The synthetic liquid-fuel potential of Utah: U.S. Army Corps of Engineers, Summary report for the U.S. Bureau of Mines, Department of the Interior: Ford, Bacon \& Davis, Inc., Engineers.

The only known reserves of oil-impregnated strippable deposits in Utah are bituminous sandstones in the Sunnyside deposit, in Carbon County, and the P. R. Springs deposit, in Grand and Uintah Counties. Deposits of bituminous sandstones that might fall within the definition of reserves, if more data were available, are present in the Whiterocks area and at Vernal or Asphalt Ridge. Both are in Uintah County, in the northern part of Uinta Basin. Smaller occurrences of oil-saturated sandstones, in the central and southern parts of the State, are of little prospective commercial importance. Author's text condensed.

Bardwell, Carlos, Berryman, B. A., Brighton, T. B., and Kuhre, K. D., 1918, Chemical properties of Utah hydrocarbons: Utah Acad. Sci., Arts and Letters Proc., v. 1, p. 78-95.

About 15 kinds of hydrocarbons occur in Utah; the five most abundant are gilsonite, tabbyite, wurtzilite, ozokerite, and rock asphalt and are the ones selected for this investigation. One asphalt gradually changes into another; gilsonite occurs farthest east; then, the tabbyite, wurtzilite, rock asphalt, and ozokerite occur successively westward. There may be a genetic relationship among them. All occur in Eocene or Tertiary rocks. Gilsonite, tabbyite, ozokerite, and rock asphalt are soluble in many solvents to varying degrees, but wurtzilite is practically insoluble in all the solvents tried. Although gilsonite, tabbyite, and wurtzilite grade from one to the other in the field, are closely similar in appearance, and very similar in chemical composition, they differ markedly in solubilities and certain other properties. Authors' text condensed.

Bassler, Harvey, and Reeside, J. B., 1922, Oil prospects in Washington County, Utah: U.S. Geol. Survey Bull. 726-C, p. 87-107.

Washington County, in the extreme southwest corner of Utah, shows only meager evidence of oil. In Rock Canyon, which cuts the Hurricane fault scarp about 15 miles south of Hurricane, a deep wide gash was eroded into the upper part of the Kaibab limestone and filled with gypsum, shale, and limestone of the basal part of the overlying Moenkopi formation. This filling is very irregular in composition and contains many thin veins of asphaltite and zones impregnated with bituminous matter. The material is more abundant in the lower part of the exposure, and it seems to have come up from below. In another exposure 2 miles west of the south end of Black Rock Canyon, in Arizona, a crushed zone $\mathbf{1 0 0}$ feet wide in the lower part of the Moenkopi formation is filled with bituminous matter in the form of veins and impregnations. This material likewise seems to have come up from below. Authors' text condensed. 
Boutwell, J. M., 1905, Oil and asphalt prospects in Salt Lake basin, Utah: U.S. Geol. Survey Bull. 260-J, p. 468-479.

The only occurrence of asphalt known in this region is in the northwestern part of the Great Salt Lake, at Rozel Hills. This occurrence of asphalt appears to be restricted to the shallow littoral part of the Great Salt Lake, 1/4-1 mile from the present shoreline (1904), immediately southeast of Rozel Hills. It exudes through the unconsolidated material on the bottom of the lake and bubbles up into the water as hollow spherical, or tubular, masses 1-2 inches long and as threads and hairs 6-18 inches long. In places, the emissions are concentrated into considerable seepages or "pitch springs," 1-2 feet in diameter. The source of these seeps appears to be a bed of asphalt, 2-3 feet thick, 80 feet below the present lake bed and an underlying series of asphaltic beds 3-5 feet thick. The asphaltic matter cements the calcareous oolitic deposits of the lake bottom into a bituminous limestone and forms numerous low islets, from 1 to 50 feet in diameter, which are distributed in rough alinement. The seepages may be along zones of fracture. Author's text condensed.

Bowman, J. L., 1969, Oil-impregnated sandstones between [the] Dirty Devil and Colorado and Green Rivers, Garfield and Wayne Counties, Utah [abs.]: Am. Assoc. Petroleum Geologists Bull., v. 53, no. 1, p. 218.

Oil-impregnated sandstone has been known in Elaterite basin, Wayne County, Utah, since the early 1900's. Genetically related deposits occur in a triangular area that is bounded by the Green and Colorado Rivers on the east, by the Dirty Devil River on the west, and by a poorly defined line on the north. The area is here called the "Tar-sand triangle." Major deposits occur in the White Rim Sandstone Member of the Cutler Formation (Permian). Less important deposits, generally in close association, are in the Organ Rock and Cedar Mesa Members of the Cutler (below the Rim Rock) and in the lower part of the overlying Triassic Moenkopi Formation. The degree of oil impregnation ranges from very slight to fully saturated (with active seeps) in an area 22 miles long and 1.5 miles wide. Maximum thickness of the oil-impregnated rocks is 250 feet. Reserves observable in outcrops exceed 1 billion barrels of $8^{\circ}-15^{\circ}$ API oil. The known continuity of deposits beneath the surface makes it possible to estimate reserves of 3-4 billion barrels. These deposits are probably offshore bars that have been breached by erosion, permitting the volatile hydrocarbons to dissipate. Author's abstract condensed.

Breger, I. A., and Deul, M., 1959, Association of uranium with carbonaceous materials, with special reference to Temple Mountain region, in Garrels, R. M., and Larsen, E. S., 3d, compilers, Geochemistry and mineralogy of the Colorado Plateau uranium ores: U.S. Geol. Survey Prof. Paper 320, p. 139-149.

On the Colorado Plateau, uranium is associated with coalified wood, crude oil, carbonaceous shale, and carbonaceous matter of unknown origin. Investigations have shown that crude oil plays no role in the emplacement of uranium, although its ability to pick up small quantities of uranium while migrating through uraniferous zones may make oils an aid to general prospecting. 
Byrd, W. D., II, 1967, Geology of the bituminous sandstone deposits, southeastern Uinta Basin, Uintah and Grand Counties, Utah: Utah Univ. unpub. M.S. thesis, $43 \mathrm{p}$.

The bituminous sandstone beds in the southeastern Uinta Basin underlie an area of 214 square miles; they may extend northward. Saturated zones 3-75 feet thick occur at or near the surface in a 250 -foot-interval that dips gently northward. Saturation occurs in lenticular sandstone beds, and occasionally in siltstone beds, in the Green River Formation. These lenticular beds were deposited on the periphery of the basin in a fluvio deltaic environment. Mesozoic rocks at depth have formed drape folds over displacements on normal fault blocks in the Precambrian basement rocks of the Uncompahgre uplift. These folds, weakly reflected in the beds of the Green River Formation at the surface, have "funneled" the bituminous saturation to the area around $P$. R. Spring, where it seeps to the surface. Reserve estimates indicate a possible $3,700,000$ barrels of oil in place or nearly 4 times the published estimated reserves for the Sunnyside, Utah, deposit. Author's abstract condensed.

Carey, G. A., and Roberts, I. C., 1949, Dissertation on the history, occurrence, mining, and economics of gilsonite: Utah Univ. unpub. B.S. thesis, $89 \mathrm{p}$.

There are two main gilsonite-producing districts in the Uinta Basin. The White River area includes such famous early producers as the Black Dragon and Rainbow mines. The area around Fort Duchesne and Myton includes the first-discovered Duchesne vein, and the Pariette and several other veins. The veins of the White River area vary in width from several inches to 18 feet (the Eureka vein). They crop out in the upper part of the Green River formation and lower part of the Uinta formation with an approximate strike of N. $60^{\circ} \mathrm{W}$. The veins around Fort Duchesne and Myton occur in the lower Duchesne River formation and in the upper Uinta formation. The veins in this area trend $\mathrm{N}$. $45^{\circ} \mathrm{W}$. Production has been variable, depending upon the demand. At the time this report was written, 1945 was the peak year for production with 61,273 tons.

Carman, E. P., and Bayes, F. S., 1961, Occurrence, properties, and uses of some natural bitumens: U.S. Bur. Mines Inf. Circ. 7997, 42 p.

In Uintah County, Utah, a pure solid asphalt has been found in Tabby Canyon, about 30 miles west of Fort Duchesne. Another Utah deposit was found below the bed of the Great Salt Lake, about 10 miles south of Rozel. This material exudes through the lake bottom and floats to the surface in lumps 1-2 feet in diameter. Carbon, Utah, Grand, and Uintah Counties have deposits of asphaltic limestone or asphaltic sandstone. Deposits of gilsonite have been found only in the Uinta Basin, in a belt about 65 miles long, extending from Rio Blanco County, Colo., through Uintah County, Utah, into Duchesne County. The gilsonite occurs in almost pure form in vertically outcropping parallel veins. It varies in thicknass from thin fissures to as much as 22 feet and ranges in depth from about 100 feet near the east end of the belt to about 2,000 feet at the west end, where it has been mined to a depth of 1,500 feet.

Cashion, W. B., 1964, Other bituminous substances, in Mineral and water resources of Utah (Report of the U.S. Geological Survey for use of U.S. 
Senate Committee on Interior and Insular Affairs) : 88th Cong., 2d Sess., U.S. Govt. Printing Office, p. 63-68.

Gilsonite occurs in northeastern Utah in Uintah and Duchesne Counties as veins in northwest-trending vertical fractures that cut the gently dipping beds of the Tertiary Duchesne River, Uinta, Green River, and Wasatch Formations. They range in width from a fraction of an inch to about 18 feet, and the maximum length is 14 miles. Information on the veins at depth is limited, but mining in eastern Duchesne County has reached a depth of about 1,500 feet. It is estimated that the original gilsonite reserves of Utah amounted to about 45 million tons. Gilsonite produced to date amounts to about onetenth of the estimated original reserves. Ozokerite and wurtzilite also occur as vein fillings in Wasatch, Utah, and Duchesne Counties. The most important rock-asphalt deposits are at Sunnyside and Asphalt Ridge. The Sunnyside bituminous sandstone deposits are about 5 miles north of the town of Sunnyside, Carbon County. The bituminous sandstone beds crop out in the cliffs and steep slopes in the upper part of the Wasatch Formation and in the lower part of the Green River Formation; however, most of them are in the Wasatch. In 1948 Holmes estimated that the area contained 1,600 million cubic yards of bituminous rocks in which beds with 9 percent or more bitumen, by weight, contain 728 million barrels of bitumen. The Asphalt Ridge bituminous sandstones lie a few miles northwest of Vernal, in Uintah County. Impregnated beds of sandstone crop out along a northwest-trending strip that is about 14 miles long and less than 1 mile wide. The bitumen occurs in the Cretaceous Mesaverde and Tertiary Duchesne River Formations. Thicknesses of impregnated sandstone sequences at the outcrop range from a few feet to about 200 feet. The bitumen content ranges from about 8 percent to a little more than 15 percent. In 1930 Spieker estimated that the area within $1 \frac{1}{2}$ miles from the outcrop included 1,970 million tons of bituminous rock containing 1,150 million barrels of bitumen. Author's text condensed.

Cashion, W. B., 1967, Geology and fuel resources of the Green River Formation, southeastern Uinta Basin, Utah and Colorado: U.S. Geol. Survey Prof. Paper 548, 48 p.

Gilsonite occurs as long narrow vein deposits between the walls of northwest-trending, nearly vertical joints. Veins in the mapped area are from 0.5 to 7 miles long and from a few inches to about 18 feet wide. The maximum vertical extent is estimated to be about 1,400 feet. The veins are almost parallel, and the average strike is approximately $\mathrm{N}$. $60^{\circ} \mathrm{W}$. In the mapped area gilsonite veins occur in the Wasatch, Green River, and Uinta Formations. Northwest of the mapped area, veins also occur in the Duchesne River Formation. Most of the widest and longest veins are found in the Uinta Formation. Gilsonite is a residue of petroleum that flowed into fractures from a source not definitely known. After filling the fractures, most of the hydrocarbons solidified. The original reserves of gilsonite in the basin are estimated to have been about 45 million tons; about one-tenth of this amount has now been mined. Sandstones impregnated with bituminous material occur in the uppermost part of the Douglas Creek Member and in the lowermost part of the Parachute Creek Member, both of the Green River Formation. The highly impregnated beds are very dark gray and are cemented by the tarry bituminous material. On very warm days bitumen oozes from some beds. The source of the bituminous material has not been determined; however, it 
is seemingly indigenous to the Green River Formation, although no likely source beds occur adjacent to the impregnated sandstone. Author's text condensed.

Cashion, W. B., and Brown, J. H., Jr., 1956, Geology of the Bonanza-Dragon oil-shale area, Uintah County, Utah, and Rio Blanco County, Colorado: U.S. Geol. Survey Oil and Gas Inv. Map OM-153, with text.

Most of the gilsonite veins in the Uinta Basin are within the BonanzaDragon area. The largest veins are the Cowboy, Independent, Tabor, Little Bonanza, Rainbow, and Black Dragon veins. The width of the veins ranges from a fraction of an inch to 18 feet and the length from a few hundred feet to 14 miles. The depths to which they extend are unknown, but prospecting has indicated that they extend to as much as 1,500 feet. The walls of the gilsonite-filled fissures are nearly vertical and smooth. The veins commonly contain fragments of wallrock. At some localities the gilsonite has permeated the sandstone beds for several feet on both sides of the vein. The veins near Bonanza, Utah, are exposed in the Uinta formation and in the upper part of the Green River formation. Authors' text condensed.

Cohenour, R. E., 1964, Fossil hydrocarbons of the Tri-State Basins, in Intermountain Symposium on Fossil Hydrocarbons, Proceedings: Brigham Young Univ., Salt Lake Center for Continuing Education, Salt Lake City, Utah, p. 281-288.

Bituminous sandstones make up available reserves of 1.4 billion barrels of petroleum in the Uinta Basin and, although more significant than gas, oil, or gilsonite, make up less than 0.1 percent of the energy in the available reserves of the Tri-State (Utah-Colo.-Wyo.) area. Total bituminous sandstone or rock asphalt resources in Utah equal 5.6 billion barrels, or about 0.1 percent of the energy potential. Four deposits - Sunnyside ( 728 million barrels), Carbon County; Asphalt Ridge (460 million barrels), Uintah County; P. R. Springs (200+ million barrels), Uintah-Grand Counties; and Whiterocks Canyon (50 million barrels), Uintah County - contain the available reserves of 1.4 billion barrels. The potential reserves would be at least 3 times the available reserve ( 1.4 billion), or 4.2 billion barrels, for a total resource of 5.6 billion barrels. Author's text condensed.

Covington, R. E., 1957, Bituminous sandstones of the Asphalt Ridge area, northeastern Utah, in Guidebook to the geology of the Uinta Basin: Intermountain Assoc. Petroleum Geologists Guidebook, 8th Ann. Field Conf., p. 172-175.

Asphalt Ridge derives its name from the vast amount of asphalt exposed on a topographic ridge. The structure of the ridge is homoclinal, with a southwesterly dip. Oil saturation occurs in the Mesaverde, Uinta, and Duchesne River formations; saturation is related to permeability and porosity of sandstone beds that are near an unconformity or that are truncated downdip at an unconformity. The accumulation of oil is probably related to the unconformities in the Asphalt Ridge homocline, and the source of the oil is the limestone and shale in the lower part of the Green River formation. Author's text condensed. 
Covington, R. E., 1963, Bituminous sandstone and limestone deposits of Utah, in Oil and gas possibilities of Utah, reevaluated: Utah Geol. and Mineralog. Survey Bull. 54, p. 225-247.

The major bituminous sandstone and bituminous limestone deposits of Utah are within or along the edges of the Uinta Basin in Carbon, Duchesne, and Uintah Counties. The Sunnyside deposits in Carbon County contain the greatest reserves of bituminous sandstone in the United States. The sandstone averages $8-10$ percent bitumen by weight, totaling more than 1.6 billion cubic yards of bitumen. The second largest deposit in Utah is the Asphalt Ridge bituminous sandstone area in Uintah County; reserves have been estimated at more than 1 billion barrels. The deposits at Peor Springs and Whiterocks Canyon areas are described. The Asphalt Ridge, Sunnyside, Peor Springs, and Whiterocks Canyon area deposits contain more than 90 percent of the asphalt reserves in the State of Utah. Author's introduction condensed.

Covington, R. E., 1964a, Bituminous sandstones in the Uinta Basin, in Guidebook to the geology and mineral resources of the Uinta Basin, Utah's hydrocarbon storehouse: Intermountain Assoc. Petroleum Geologists Guidebook, 13th Ann. Field Conf., p. 227-242.

The bituminous sandstones of the Sunnyside area are the largest known deposits in the United States. The deposit contains 1.6 billion cubic yards of bituminous sandstone, of which approximately 50 percent is commercial grade containing more than 9 percent bitumen by weight. The bituminous sands of this deposit are in the upper part of the Wasatch Formation and in the lower part of the Green River Formation. The saturated beds range in thickness from a few inches to more than 350 feet. The oil originated in the Green River Formation, but soon after burial and before consolidation and induration, the oil moved from the source beds into the adjacent and subjacent sandstones.

Asphalt Ridge, 4 miles west of Vernal, is the second largest bituminous sandstone deposit in Utah. Along the ridge, well up in the Duchesne River Formation, there are important beds of asphalt, all lying along angular unconformities. The degree of saturation is a direct function both of proximity of these beds to unconformities and of porosity and permeability within these beds. The bitumen has a $12^{\circ}$ API gravity and is extremely low in sulfur. The oil probably originated in the lacustrine Green River Formation. The reserves of bituminous sandstone of commercial grade are in excess of 475 million cubic yards of material containing more than 9 percent bitumen, by weight, for a total of approximately 250 million barrels of bitumen.

The bituminous sandstones of the Whiterocks area are approximately 25 miles northwest of Vernal, along the south flank of the Uinta Mountains. The Triassic(?)-Jurassic Navajo Sandstone in this area has a total thickness of 1,000 feet. Asphalt saturation occurs fairly uniformly throughout the entire formation. The bitumen has an API gravity of $12^{\circ}$ and is low in sulfur. The bituminous sand of the Navajo Sandstone averages 24.4 gallons per cubic yard. Reserves total 125 million barrels of oil in place, in all categories - that is, 65 million barrels in the proved category, 35 million barrels in the probable category, and 25 million barrels in the possible category.

The bituminous sandstone deposits of the P. R. Springs area are similar in geologic occurrence and origin to the Sunnyside deposits and lie on the southeast flank of the Uinta Basin, along the Roan Cliffs. The Chapita Wells 
area is in the east-central part of the Uinta Basin east of Ouray. The bitumen occurs in the fluvial sandstones of the Uinta Formation. The degree of saturation seems to be dependent mainly upon the proximity of the beds to fault and fracture zones from which the oil could move upward into the Uinta reservoirs. The Dragon-Asphalt Wash bituminous sandstones are south and east of the Chapita Wells deposits, in Uintah County. The richest tar sand is located adjacent to and updip from the Black Dragon gilsonite vein. The author believes that this deposit originated from the gilsonite vein, as the degree of saturation is directly proportional to the distance from the vein. The Deep Creek area is a small deposit of tarry sandstones and conglomerates 15 miles northwest of Vernal. The deposit occurs in the beds of the Duchesne River Formation that overlap with angular unconformity in the Cretaceous Mancos black marine shales. There are numerous small deposits and seeps within the Uinta Basin. Author's text condensed.

Covington, R. E., 1964b, Thermal recovery may bring industry's quiet revolution: Oil and Gas Jour., v. 62, no. 47, p. 112-118.

The quiet revolution is the application of thermal recovery to the lowgravity viscous crude oils heretofore unrecoverable by conventional and secondary recovery techniques and to the tremendous reserves of bituminous sandstones. Two areas in Utah have bituminous sandstones of economic significance with respect to thermal-recovery methods of oil production. The more important area is in the Uinta Basin, in northeastern Utah, in Uintah, Duchesne, and Carbon Counties. The second area is the Green River Desert, in central Utah's Sevier, Wayne, and Garfield Counties. The most important deposits in the Uinta Basin are the Sunnyside deposits in Carbon County. There, the measured and indicated reserves are estimated to contain 475-500 million barrels of oil. If recovery rates are as much as 70 percent of total reserves, the recoverable oil should approach 300 million barrels. Parts of the Sunnyside reserves are adequate for large-scale strip mining. Their major drawback from the standpoint of thermal recovery is the lack of a large source of fresh water for steam injection. The bituminous sandstones of the Asphalt Ridge area are 3-4 miles west of Vernal, along U.S. Highway 40. Proved reserves equal 475 million cubic yards of material containing 250 million barrels of oil. Probable reserves are estimated at about 500 million barrels, with additional reserves indicated in a downdip basinward direction. The bitumen is in the Cretaceous Asphalt Ridge and Rim Rock sandstones of the Mesaverde Formation and in the unconformably overlying Eocene Duchesne River Formation. The richest impregnation lies along and close to unconformities. An ample supply of water is available for both mining and steam-flooding operations in the Asphalt Ridge area. The bituminous sandstones of the Whiterocks area are 20 miles northwest of Vernal, along the mountain front on the south flank of Uinta Mountains, in northeastern Utah. The bitumen fills the pore spaces and coats the sand grains of the Jurassic Navajo Sandstone. The proved reserves of this deposit, as determined from core drilling, are 125 million barrels of oil in place, with possible additional reserves of another 120 million barrels to the northeast and to the southwest of Whiterocks Canyon. This deposit has perhaps the greatest recoverable reserves of oil of any bituminous sandstone on the continent. Recoverable reserves approach 132,000 barrels per acre; the Athabaska tar sands, in comparison, have recoverable reserves of only 90,000 barrels per acre, but are much greater in areal extent. Author's text condensed. 
Covington, R. E., 1965, Some possible applications of thermal recovery in Utah: Jour. Petroleum Technology, v. 17, no. 11, p. 1277-1284.

The most important deposits in Utah from the standpoint of thermal recovery are those of the Sunnyside area, in Carbon County, and the Asphalt Ridge-Vernal deposits, in Uintah County. Two other areas which have thermal-recovery potential are the Whiterocks area, in Uintah County, and the San Rafael Swell-Naquoia Arch area, in Emery, Wayne, and Garfield Counties. A preliminary evaluation of these four areas is given from the standpoint of geology, reservoir engineering, costs, markets, and future development possibilities. The four areas mentioned above, and perhaps three of six areas of lesser importance, compare favorably with areas now being developed by thermal methods in California, Oklahoma, Texas, and Kansas. Author's abstract condensed.

Crawford, A. L., 1949, Gilsonite and related hydrocarbons of the Uinta Basin, Utah, in Oil and gas possibilities of Utah: Utah Geol. and Mineralog. Survey, Salt Lake City, Utah, p. 235-254.

Gilsonite belongs to the family of substances known as "asphaltites," which includes grahamite and glance pitch. Asphaltites are as different from asphalt as asphalt is from petroleum, or as different as petroleum is from natural gas. Although gas, petroleum, asphalts and asphaltites all belong to the hydrocarbon series, they each constitute a distinct, but overlapping, series in which the composite molecular arrangement and other properties seem to vary chiefly with the degree of polymerization or fractionation, and with the molecular history of the member of the series being considered. The author regards gilsonite as a solid solution of heavy-hydrocarbon molecules derived from still heavier, less mobile molecules of kerogen. The fractionation of the kerogen probably took place in a substantially closed system under the influence of heat, pressure, and mineral catalysts. Once having been formed, the gilsonite molecules were probably transported, in part through solution, in the lighter petroleum fractions, which will dissolve and, upon evaporation, precipitate again as gilsonite. The author attributes the immediate origin of gilsonite to the bituminous sandstones that are interbedded with, and lie beneath, the Green River formation. The bitumen in the "rock asphalt" is more mobile and, therefore, is more easily available to fill wide fissures opening from beneath, than is the more solid, more disseminated, relatively inert kerogen in the richer members of the Green River formation. Author's text condensed.

Crawford, A. L., 1953, Ozokerite - A possible new source: Utah Acad. Sci., Arts and Letters Proc., v. 30, p. 74-82.

For many years Soldiers Summit, Utah, was the only place where ozokerite was mined commercially. Ozokerite is now being obtained from a new oil well in the Roosevelt oil field, in the Uinta Basin. From a depth of 9,357-9,393 feet, this well produces 1,600 barrels of petroleum per day, 50 percent of which is wax. The oil well bottoms in the base of the oil shales of the Green River formation, near where they intertongue with the Colton formation. Author's text condensed.

Crawford, A. L., 1957, Gilsonite - Its discovery and the early history of the industry, in Guidebook to the geology of the Uinta Basin: Intermountain Assoc. Petroleum Geologists Guidebook, 8th Ann. Field Conf., p. 149-151. 
Gilsonite was named after Samuel H. Gilson, who believed that the new substance had commercial possibilities, and who set out to promote its use in industry. The name gilsonite became locally applied to the substance, which by laws of scientific usage should be known as "uintahite," the name given in 1885 by Blake, who published the first scientific description of it. There have never been more than a few companies exploiting gilsonite. The one major company, the American Gilsonite Co., has produced more gilsonite than all the others combined. The center of production has gravitated from the Carbon vein at Moffat, to the Dragon, to the Rainbow, and finally to the Cowboy-Bonanza vein - each move resulting from the interaction between the economics of production and transportation. The long freight haul by horse teams in tandem-drawing heavy wagons with trailers gave way to the picturesque Mallet engine that climbed the precipitous Book Cliffs on the narrow-gage railroad from Mack, Colo., to Dragon, Utah. The track-bound railroad gave way to the gasoline-powered truck, which, in turn, was replaced by a pipeline through which a slurry of gilsonite fines suspended in water is pumped to the Fruita, Colo., gilsonite treatment plant.

Crawford, A. L., and Pruitt, R. G., 1963, Gilsonite and other bituminous resources of central Uintah County, Utah, in Oil and gas possibilities of Utah reevaluated: Utah Geol. and Mineralog. Survey Bull. 54, p. 215-221.

Central Uintah County, in northeastern Utah in the Uinta Basin, is underlain by relatively undisturbed Tertiary lacustrine and fluviatile sediments. This area contains all the known gilsonite veins in the Western United States. Nearby parts of the basin contain smaller deposits of other unusual bituminous substances, such as wurtzilite, tabbyite, ingramite, albertite, and ozokerite, the last of which is a native paraffin. Gilsonite veins occur as a filling in vertical tensional cracks in the competent sedimentary beds. These veins commonly are 3-4 feet wide, and the Cowboy vein at one point is 17 feet wide. The veins trend northwestward for miles across the rolling terrain and extend vertically downward until they reach the incompetent mudstones of the Uinta Formation and the oil shales of the Green River Formation. In the latter, the veins "break up" into smaller branching veins and, ultimately, into veinlets. At least two veins - the Weaver-Colorado and the Black Dragon - are known to extend beneath the oil-shale horizon into the underlying members. Hunt, Stewart, and Dickey (1954) showed that the gilsonite of the region is derived from the upper Green River Formation oil shales, flowing upward into open tensional cracks. Authors' text condensed.

Davidson, E. S., 1967, Geology of the Circle Cliffs area, Garfield and Kane Counties, Utah: U.S. Geol. Survey Bull. 1229, 140 p. [p. 69].

The lowermost beds of the Shinarump Member of the Chinle Formation contain disseminated brown specks of asphalt. Locally, the asphalt is so abundant that brownish-black liquid seeps out along the contact with the underlying Moenkopi Formation. Where asphalt occurs in the Shinarump, some has penetrated into the upper few feet of the Moenkopi, and the ridges of Moenkopi on the channel contacts are heavily impregnated. The gray Moenkopi contains 0.16-1.68 percent organic carbon, but there seems to be no direct correlation between organic material and uranium content. Author's text condensed. 
Davis, L. J., 1957, Geology of gilsonite, in Guidebook to the geology of the Uinta Basin: Intermountain Assoc. Petroleum Geologists Guidebook, 8th Ann. Field Conf., p. 152-156.

The physical properties of gilsonite (uintahite) are its black color, brilliant luster, homogeneous texture, extreme brittleness, and conchoidal fracture. The melting point varies widely from about $250^{\circ} \mathrm{F}$ to more than $400^{\circ} \mathrm{F}$. Various theories have been advanced as to the origin of the gilsonite: (1) filling of the fissures from an overlying asphalt lake or source bed; (2) carbonaceous material from rocks below the Green River formation; and (3) bituminous material that originated in the Green River marlstone. The last theory seems to have the greatest influence at present. Author's text condensed.

Donnell, J. R., Culbertson, W. C., and Cashion, W. B., 1967, Oil shale in Green River Formation, in Occurrences and prospects of oil shale: 7th World Petroleum Congress, Proc., v. 2, panel discussions, 14 p.

Oil and gas are produced from the shore facies of the Green River Formation at several fields in the northern part of the Uinta Basin. The shore facies also contains asphaltic sandstones in several parts of the basin. Gilsonite veins, which are nearly vertical, are as much as 18 feet wide, are in massive sandstone beds of the Uinta Formation and in those of the shore facies of the Green River Formation. Authors' text condensed.

Eardley, A. J., 1963, Oil seeps at Rozel Point: Utah Geol. and Mineralog. Survey Spec. Studies 5, $32 \mathrm{p}$.

A series of surface seeps of a heavy black oil occur just south of Rozel Point, along the north shore of Great Salt Lake. The rocks consist of black basalt flows and interbedded lenses of light-grayish-tan limestone. The oil emerges from the soft lake clays and, when the area is covered by water, rises as small viscous stringers. The boulders of basalt and limestone along the shore are heavily coated with oil. It appears that considerable oil is present, but its mode of occurrence is uncertain.

Eardley, A. J., and Haas, Merrill, 1936, Oil and gas possibilities in the Great Salt Lake Basin: Utah Acad. Sci., Arts and Letters Proc., v. 13, p. 61-80.

The authors present the following conclusions regarding the oil seeps of Rozel Point: (1) The oil is a heavy, pitchy asphalt crude, which emerges through seeps under salt water on the lake bed. It is probably not an evaporation residue; rather, it is probably the original oil that evolved by natural decomposition or distillation of organic matter. (2) It comes from depths of 80-140 feet in horizontal lake beds of Quaternary age. The oil exists in "asphaltic" beds 3-5 feet thick. (3) Organic matter in the form of peat has been penetrated in many shallow water wells drilled in the Great Salt Lake Basin; hence, the oil is believed to have resulted from plant alteration. (4) An unusual physical or chemical condition must exist at Rozel Point, because there are other similar oil seeps known at the present time. This would suggest that the salt water of the Great Salt Lake was not locally instrumental in the generation of oil; otherwise, oil seeps would occur elsewhere around the lake. Salt water may be necessary for the formation of the oil, but some other condition or circumstance may have made the Rozel Point geology unusual. (5) The oil is believed to reach the surface through compaction fissures, rather than along a fault surface. Authors' text condensed. 
Eldridge, G. H., 1901, Utah, in The asphalt and bituminous rock deposits of the United States: U.S. Geol. Survey 22d Ann. Rept., pt. 1b, p. 209-452 [p. 340-354].

The gilsonite veins on the Colorado-Utah border were being mined at the time Eldridge wrote this report. Asphaltic limestone was being mined at Tie Fork of Soldier Creek, 7 miles northwest of Clear Creek Station (Tucker Post Office). This report contains detailed descriptions of each vein, as well as maps and cross sections. Deposits of asphaltic sandstone had received little attention up to this time.

Fene, W. J., 1928, The mining of gilsonite in Utah: U.S. Bur. Mines Inf. Circ. $6069,6 \mathrm{p}$.

Gilsonite occurs in veins in a solid homogeneous mass and breaks with a conchoidal fracture. Even in the smallest pieces, the brilliant luster is preserved. Long exposure to the weather causes it to become dull and black. Occasionally, it has a fine columnar structure at right angles to the walls. This so-called pencilated ore is commonly found on both sides of the vein. The specific gravity of gilsonite is 1.035 , its hardness is 2 , and its streak on a porcelain plate is brown. The greatest amount of gilsonite is found in the Uinta Basin north of the White River. Three large, nearly parallel veins extend N. $60^{\circ}$ W., and their dip is nearly $90^{\circ}$. The Cowboy vein is the largest and has a maximum width of 18 feet for a distance of about 2 miles north of the White River. It is at least 10 feet wide for 3-4 miles, and is more than 6 feet wide for several more miles north of the White River. The most plausible theory of origin of the veins appears to be that the formation of this synclinal basin produced gigantic cracks in the brittle and nonelastic sandstone of the Uinta formation, with enough heat to distill the oily matter from the underlying Green River shales. Author's text condensed.

Gregory, H. E., and Moore, R. C., 1931, The Kaiparowits region - A geographic and geologic reconnaissance of parts of Utah and Arizona: U.S. Geol. Survey Prof. Paper 164, 161 p.

Oil seeps and oil-impregnated sandstone occur in parts of the Kaiparowits region. The Pennsylvanian rocks yield heavy oil in the San Juan oil field, Utah, and they are distinctly bituminous at many places in southwestern Colorado. Conditions are not very favorable for accumulations of oil and gas in commercial quantities. The stratigraphic relations, especially in relation to the relative scarcity of the shale, do not favor production of oil, even though oil seeps have been found and high-grade oil is obtained in a number of wells. Authors' text condensed.

Hail, W. J., Jr., 1957, Utah, in Reconnaissance for uranium in asphalt-bearing rocks in the Western United States: U.S. Geol. Survey Bull. 1046-E, p. 55-85 [p. 67-69].

The asphalt in the Vernal area, Uintah County, was the most uraniferous of those examined in Utah. The uranium content of 21 samples ranges from 0.001 to 0.150 percent, and averages 0.028 percent, in the ash of the extracted oil. All five of the asphalt-bearing areas sampled in Utah are in the Uinta Basin. The deposits in the Vernal, Bonanza, P. R. Springs, and Sunnyside areas are in the Wasatch, Green River, and Uinta formations of Eocene age. The deposit in the Whiterocks Canyon area is in the Navajo sandstone of 
Jurassic and Jurassic(?) age. The asphalt deposits in the Bonanza area are gilsonite, and the deposits in the other areas are asphalt-bearing sandstone. Author's text condensed.

Henderson, J. H., Jr., 1957, The gilsonite refining project of the American Gilsonite Co.: Guidebook to the geology of the Uinta Basin, Intermountain Assoc. Petroleum Geologists Guidebook, 8th Ann. Field Conf., p. 157-160.

The American Gilsonite Co., owned by Standard Oil Co. of California and the Barber Oil Corp., has placed in operation a 6-inch 72-mile pipeline to transport 700 tons of gilsonite per day from mines located in a remote section of eastern Utah to a refinery near Grand Junction, Colo. There, the gilsonite is converted into high-purity electrode coke and gasoline. The coke is used in the manufacture of aluminum. This is the first privately financed project for large-scale production of conventional petroleum products from a raw material other than crude oil. Author's text condensed.

Hess, F. L., 1922, Uranium-bearing asphaltite sediments of Utah: Eng. and Mining Jour., v. 114, no. 7, p. 272-276.

An asphaltite carrying uranium, vanadium, and other metals and metalloids occurs in southeastern Utah, at Temple Mountain, 45 miles southwest of the town of Green River, and at adjacent localities on the eastern flank of the San Rafael Swell, Emery County. The asphaltite occurs in the sandy parts of the Shinarump conglomerate. It is contained in the sandstone as particles ranging from the size of a pinhead to more than 2 inches in diameter. Where the asphaltite weathers from the sandstone, it leaves round cavities, showing that it had been an integral part of the sandstone, and not merely a filling of interstices. The asphaltic material appears markedly varied at different places. Where the asphaltic material carries the metals and metalloids, it is a glistening black, and in other places it has the brownish color and general appearance of oil-soaked sand. The origin of this type of deposit is puzzling. Perhaps only that asphaltite which absorbed these elements became hard quickly, and the physical differences between the asphaltites may have developed because a part was exposed to and picked up the uranium, vanadium, and other elements, whereas those parts of the asphaltites which did not pick them up remained unhardened for a longer time and were less altered. Author's text condensed.

Holmes, C. N., Page, B. M., and Averitt, Paul, 1948, Geology of the bituminous sandstone deposits near Sunnyside, Carbon County, Utah: U.S. Geol. Survey Oil and Gas Inv. Prelim. Map 86, with text.

The bituminous sandstone deposits near Sunnyside, Carbon County, Utah, are the largest known in the United States. Conservatively estimated, the Sunnyside deposits contain 1.6 billion cubic yards of measured, indicated, and inferred bituminous sandstone, half of which is believed to contain at least 9 percent bitumen by weight. The bituminous beds are in the upper part of the Wasatch formation and in the lower part of the overlying Green River formation. The deposits extend about 9 miles along the outcrop. The beds lie at elevations between 9,000 and 10,000 feet, near the top of Book Cliffs. Authors' text condensed. 
Hunt, J. M., 1963, Composition and origin of the Uinta Basin bitumens, in Oil and gas possibilities of Utah, reevaluated: Utah Geol. and Mineralog. Survey Bull. 54, p. 249-273.

The Uinta Basin represents a unique environment - nonmarine, yet varying from brackish to highly saline water. Although the original waters were oxidizing, they later became strongly reducing, and the toxic hydrogen sulfide in the bottom layers resulted in a tremendous collection of organic matter. This resulted in deposition of several thousand feet of bituminous sediments. As the area later became uplifted, tension cracks slowly opened at depths, and forms of ozokerite moved into the veins. In successively younger sediments, viscous forms of albertite, gilsonite, and wurtzilite filled the openings as they formed. As time went on and the uplifting continued, these materials polymerized and hardened to become the solids we now see. The changes in the type of bitumens originating in successively younger beds coincide with changes in the minerals and the fossils. Apparently, they all reflect changes in depositional environment. Author's text condensed.

Hunt, J. M., Stewart, Francis, and Dickey, P. A., 1954, Origin of the hydrocarbons of the Uinta Basin, Utah: Am. Assoc. Petroleum Geologists Bull., v. 38 , no. 8 , p. $1671-1698$.

The hydrocarbons of the Uinta Basin occur as veins in the oil shales, as saturated sands in contact with the oil shales, and as filling in fractures and fissures extending from the oil shales. The bituminous lake beds are considered to be the source of the vein hydrocarbons, inasmuch as these beds still contain appreciable quantities of organic matter, the soluble part of which is comparable in composition with the vein hydrocarbons. The different hydrocarbons of the Uinta Basin originated at different times, in the following sequence: Ozokerite, albertite, gilsonite, and wurtzilite. Changes in the types of hydrocarbons upward in the Eocene section coincide with changes in the minerals and fossils. Apparently, all the changes were controlled by a shifting environment under which the lake beds were deposited. Authors' conclusions.

Kayser, R. B., 1966, Bituminous sandstone deposits, Asphalt Ridge: Utah Geol. and Mineralog. Survey Spec. Studies 19, 62 p.

Asphalt Ridge is the second largest bituminous sandstone deposit in the Uinta Basin. Discontinuous concentrations of bitumen occur in the Rim Rock Sandstone of the Mesaverde Group (Cretaceous), in the overlying Uinta Formation (Eocene), and in the Duchesne River Formation (Oligocene). Development of "in-situ" (thermal) recovery methods, such as those discussed in this report, may reduce the projected production costs to a level at which oil from bituminous sands can compete with oil from conventional sources. Because the bituminous layers dip southwestward under prohibitively deep cover, only a small part of the sandstone can be mined by open-pit methods. However, the thick uniform sands of the Mesaverde Group are well suited for thermal-recovery techniques. Recoverable reserves in the Mesaverde should total at least $\mathbf{3 5 0}$ million barrels of oil. Author's abstract condensed.

Kelley, D. R., and Kerr, P. F., 1958, Urano-organic ore at Temple Mountain, Utah: Geol. Soc. America Bull., v. 69, no. 6, p. 701-756.

The ore at Temple Mountain is a urano-organic material. Such deposits also occur at several places on the San Rafael Swell, at Elk Ridge, in eastern 
Utah, in New Mexico, and at Placerville, Colo. At Temple Mountain, most of the ores are concentrated in the Moss Back member of the Chinle formation and are distributed throughout an area of about 1 square mile. Tar seeps occur in many places, and porous sandstones from the Coconino through Wingate formations are locally oil stained. An asphaltic material physically similar to asphaltite is present in minor amounts in much of the Temple Mountain collapse. Three types of nonradioactive petroliferous materials are recognized at Temple Mountain: fluid or semifluid tar, dry tar impregnating the sandstones, and asphalt. Black to dark-brown viscous tar is common; it forms seeps and viscous impregnations along bedding planes, fractures, and faults. Sediments impregnated with dry oil are conspicuous. Bleaching within or bordering the Temple Mountain collapse may be attributed, in part, to the reduction of iron by petroleum. The impregnated fresh rock is light brown, and the oil forms a thin coating on detrital grains, without corrosive effect. The organic material represents a stage in the normal oxidation of petroleum. A hardened, brittle black lustrous nonuranium-bearing petroliferous material (asphalt) occurs in dolomitized, sideritized, and goethite-bearing masses on and near Temple Mountain. It fills small fractures in core fragments in ore and coats calcite-filled fractures in upper Chinle strata along the south edge of South Temple Mountain. The asphalt appears to form within and near the collapse areas. It fills vugs and fractures in the Sinbad formation and is present along bedding planes and fractures in the ore-impregnated Moss Back member. The urano-organic ore at Temple Mountain is considered to have resulted from epithermal mineralization of the hot-spring type. Solutions were introduced into the ore horizon at the collapse and, to a lesser extent, along faults or fractures. Authors' text condensed.

\section{Kemmerer, J. L., 1934, Gilsonite: Utah Univ. unpub. M.S. thesis, 61 p.}

Gilsonite is a native bitumen grouped with glance pitch and grahamite under the general heading of asphaltites. It differs from these in having a brown streak and a lower specific gravity. Gilsonite occurs in veins or dikes that have developed mainly in the lower and middle Uinta sandstones. The Bonanza and the Dragon groups of veins are discussed in detail. The author regards the Green River shales as the source of the "oil" from which the gilsonite solidified. Gilsonite entered the fissures as a fluid liquid (probably in the form of asphalt-base oil, similar to, but lighter than, that which can be distilled from the Green River shales today). This fact is evidenced by the depths to which the gilsonite has impregnated the wallrock on both sides of the veins (1-2 feet in many places). Later, the gilsonite became sufficiently viscous to support and even raise to high elevations horse-rock material. Author's text condensed.

Kilborn, G. R., 1964, New methods of mining and refining gilsonite, in Guidebook to the geology and mineral resources of the Uinta Basin, Utah's hydrocarbon storehouse: Intermountain Assoc. Petroleum Geologists, 13th Ann. Field Conf., p. 247-252.

Water has proved to be a very satisfactory cutting and transporting medium; it has also been used as an explosion-control agent in mines. A pneumatically operated "jet-cutting car" applies two high-pressure $(2,000$ pounds per square inch) water streams against the ore face. The ore is penetrated and fractured by the water and washed away by low-pressure fluming water. 
In a new vertical-cutting method introduced in 1961 , a surface-to-bottom shaft and lateral drifts are established in the vein. A rotary drill on the surface then sinks 8-inch "pilot holes" on 20-foot-centers along the axis of the vein, down through the ore to the bottom tunnel level. Once the "pilot hole" has intersected the bottom drift, a special water bit is installed and, under high pressure, water is brought up through the hole to cut the surrounding gilsonite. Powerful jets of water, at approximately 2,000 pounds per square inch, cut the ore the full width of the vein. The bit is raised slowly at an average rate of 4-8 feet per hour. The fractured gilsonite falls to the tunnel level and is flumed to an underground sump for subsequent handling and processing. The gilsonite-water slurry is conveyed, by a 6 -inch pipeline, for the 72 miles from the Bonanza mine to the refinery, near Grand Junction, Colo. Author's text condensed.

Kinney, D. M., 1955, Geology of the Uinta River-Brush Creek area, Duchesne and Uintah Counties, Utah: U.S. Geol. Survey Bull. 1007, 185 p.

Sandstone, impregnated with viscous- or dry-petroleum residue, crops out at a number of places along the north side of the Uinta Basin. The largest exposure of dry-oil sand is found along the north-facing escarpment of Asphalt Ridge. It impregnates both the Tertiary Wasatch formation and the sandstones of the underlying Upper Cretaceous Mesaverde formation. The oil accumulation is probably related to the unconformity at the base of the Tertiary because saturation occurs in rocks both above and below the unconformable contact. A second, but less extensive, exposure of petroleum residue occurs in the Navajo sandstone east and west of Whiterocks River. The impregnated sandstone is well exposed west of the river, where an adit has been driven some 20 to 30 feet into the upper part of the steeply dipping Navajo sandstone. Heavy oil mixed with water seeps from the roof of the adit and accumulates on the floor. Small deposits of dry-oil-impregnated sandstone are found at several localities in the basal Tertiary beds between Deep Creek and Whiterocks River, and a dry-oil sand is exposed in the NW $1 / 4$ NE$^{1 / 4}$ sec. 24, T. 2 N., R. 3 W., between the Uinta River and Dry Gulch. Small particles of a shiny gilsonitelike hydrocarbon are found in a sandstone bed in the Park City formation in the NE1/4 sec. 34, T. 2 S., R. 21 E., north of Red Mountain. Author's text condensed.

Kinney, D. M., and Rominger, J. E., 1947, Geology of the Whiterocks RiverAshley Creek area, Uintah County, Utah: U.S. Geol. Survey Oil and Gas Inv. Prelim. Map 82, with text.

Signs of oil include oil-impregnated sands of the Navajo sandstone in Whiterocks Canyon, and oil-impregnated sands in the Mesaverde formation and the Tertiary strata on Asphalt Ridge, west of Vernal, 3 miles south of the mapped area. The accumulation of oil in the Navajo sandstone in Whiterocks Canyon may be due to the presence of a small anticlinal nose in the Paleozoic and Mesozoic rocks. Authors' text condensed.

McKnight, E. T., 1940, Geology of area between Green and Colorado Rivers, Grand and San Juan Counties, Utah: U.S. Geol. Survey Bull. 908, 147 p. [1941].

Some oil is present in the area between the Courthouse mail station and the town of Green River, Utah, as shown by the occurrence of petroleum and 
the residual products of petroleum in surface seeps and outcrops at several localities. In the Tenmile Wash region, the Moab tongue and the upper part of the Entrada sandstone are saturated to various degrees with the residual products of oil. The saturated zone is not continuous, but appears to occur as lenses 5-10 feet thick and a few hundred feet long. None of the present seeps or asphaltic residues is more than a few miles from a faulted zone; thus, the petroleum may have been derived from older, Pennsylvanian rocks, and may have reached the present surface by migration along the faults. Author's text condensed.

Merrow, Joe, 1957, Ozokerite at Soldier Summit, Utah, in Guidebook to the geology of the Uinta Basin: Intermountain Assoc. Petroleum Geologists Guidebook, 8th Ann. Field Conf., p. 161-164.

Ozokerite is a native-mineral wax of various colors and uncertain chemical composition. The simple tests described can be used to differentiate the wax from the other solid hydrocarbons of the Uinta Basin. The ozokerite mines at Soldier Summit yield little information about the veins, owing to caved-in drifts and flooded shafts. Evidence is presented to show that ozokerite was probably generated in the basal offshore lacustrine beds of the Green River formation and that it migrated laterally into the more competent shales and sandstones of the Wasatch formation. Author's abstract condensed.

Miser, H. D., 1925, Geologic structure of San Juan Canyon and adjacent country, Utah: U.S. Geol. Survey Bull. 751-D, p. 115-155.

Several oil seeps, which derive their oil from the Goodridge formation (Pennsylvanian), occur in the bottom of San Juan Canyon between Mexican Hat and the mouth of Slickhorn Gulch. The largest occurrence is a continuous series of seeps extending $1 \frac{1 / 4}{4}$ miles up the canyon from the mouth of the gulch. The oil comes up as bubbles in the water and as minute streams through sand. A black asphaltic residue cements fairly large patches of sand and rock fragments. Westward-dipping beds of the Goodridge formation, which form the lower canyon walls near the seeps, are cut by a normal fault that trends northeastward and is downthrown about 4 feet on its east side. Its presence suggests that the oil ascends along the fault plane to the alluvial material, through which it passes to the surface. The "Goodridge" oil sand, which forms a gorge and superjacent bench at the Goodridge Bridge, contains small dark areas of oil along joints and cracks. The restriction of the oil showings to the cracks and joints in the sandstone indicates that the sandstone is not uniformly porous. Author's text condensed.

Murray, A. N., 1950, The gilsonite deposits of the Uinta Basin, Utah, in Petroleum geology of the Uinta Basin: Utah Geol. Soc. Guidebook to the geology of Utah, no. 5, p. 115-118.

The gilsonite has been deposited in vertical fissures that strike N. $40^{\circ}-60^{\circ}$ $W$. The veins vary in width from a fraction of an inch to 20 feet, and some extend 20 miles in continuous outcrop. Locally, they have been mined to a depth of more than 700 feet. The depth to which they extend is not known. The walls of the fissures are generally smooth, with vertically oriented broad but low undulations. The sandstone beds in the formations generally contain the fissures, which commonly split into veinlets as they pass into the shale. Impregnation of wallrock in the larger veins is generally lacking or very slight. But, in the smaller veins, impregnation has taken place to a consider- 
able extent. The gilsonite in the veins may be massive or may possess a pencil structure similar to that of hematite. The original fractures that cut porous beds in which the viscous bitumen had accumulated are believed to have opened gradually by tension and to have filled with bitumen. Extensive inspissation later converted the viscous bitumen into gilsonite. Author's text condensed.

Pruitt, R. G., Jr., 1961a, Bituminous sandstone, in The mineral resources of Uintah County: Utah Geol. and Mineralog. Survey Bull. 71, 101 p. [p. 11-22].

Bituminous sandstones occur at several localities in the Uinta Basin, the most prominent of which is Asphalt Ridge, west and southwest of Vernal. The bituminous substance on Asphalt Ridge is a natural asphalt derived from paraffin-base petroleum that contained a high proportion of paraffin series and other saturated hydrocarbons (Covington, 1957). The sandstones in this deposit yield an average of 1 barrel of oil per cubic yard of rock, or 8-15 percent bitumen by weight. This deposit is a zone of impregnation along the Mesaverde-Uinta unconformable contact, extending downward into the Mesaverde formation (Cretaceous) and upward into the Uinta formation (Eocene). In the Whiterocks River deposit, the bitumen is in the steeply dipping Navajo sandstone (Jurassic). The impregnated zone, approximately 900 feet thick, contains an average of 20 gallons of oil per ton of rock, but ranges from 5.5 to 31.4 gallons of oil per ton of rock. The deposits on Asphalt Ridge and along the Whiterocks River are the only areas of commercial importance at this time, although there are numerous smaller occurrences of bituminous rock in the Uinta Basin. Author's text condensed.

Pruitt, R. G., Jr., 1961b, Gilsonite, in The mineral resources of Uintah County: Utah Geol. and Mineralog. Survey Bull. 71, 101 p. [p. 23-49].

Gilsonite is a black solid bitumen that approximates the composition of an asphalt-based petroleum from which most of the volatile constituents are missing. It is not to be confused with the other natural solid hydrocarbons found in veinlets in the eastern Uinta Basin that are mainly pyrobitumens. Gilsonite occurs in long thin, nearly vertical veins, most of which trend N. $35^{\circ}-65^{\circ} \mathrm{W}$., in nearly horizontal beds of Tertiary age. These unusual veins occur in an area 60 miles east-west by 24 miles north-south, in the Uinta Basin, and apparently originate from the underlying oil-shale beds of the Green River formation. This report contains maps and cross sections of the veins and detailed descriptions of each vein being mined. The gilsonite deposits of the Uinta Basin, almost all of which are in Uintah County, represent a major mineral resource. These deposits have been mined continuously since 1888 , yet the deposits have scarcely been tapped. Gilsonite reserves in Uintah County are estimated to be as much as 30 million tons. Author's text condensed.

Ritzma, H. R., 1967, Oil-impregnated sandstone deposits of Utah: Interstate Oil Compact Comm. Committee Bull., v. 9, no. 2, p. 87-98.

Fieldwork in the summer of 1967 raised the number of known deposits of oil-impregnated rocks from 33 to 47 . Deposits are found mainly in the Uinta Basin, northeastern Utah, and in central-southeastern Utah, although there are other scattered areas. The Uinta Basin contains at least 21 deposits of 
oil-impregnated oil shale, gilsonite, and oil and gas, including Red Wash field, one of the nation's largest. Six Uinta Basin (Eocene) deposits are described, as are several in the Triassic and Permian rocks of centralsoutheastern Utah. For all the deposits, stratigraphic variation is important in entrapment, and joints and fractures are important in migration. Upward migration in strongly folded and faulted areas may be extremely significant.

Ritzma, H. R., 1968a, Black gold in Utah's Circle Cliffs ?: Utah Geol. and Mineralog. Survey Quart. Rev., v. 2, no. 4, p. 4-5.

Fieldwork has outlined large deposits of oil-impregnated sandstone in the Circle Cliffs area, Garfield County. Two large deposits were found in the unnamed middle sandstone member of the Moenkopi Formation (Triassic), and two small deposits were found in the sandstone of the Shinarump Member of the Chinle Formation (Triassic).

Ritzma, H. R., 1968b, Preliminary location map of oil-impregnated rock deposits of Utah: Utah Geol. and Mineralog. Survey Map 25, with text.

Within the Uinta Basin most deposits and reserves occur in Eocene rocks - the Green River, Uinta, Duchesne River, and Wasatch Formations. The Asphalt Ridge deposit occurs in the Uinta and Duchesne River Formations and the Mesaverde Formation (Late Cretaceous). The Whiterocks deposit occurs in the Jurassic Navajo Sandstone, but apparently is not indigenous to this formation. In central-southeastern Utah, oil in the "Tar Springs Triangle" deposits appears to have originated in organic Permian rocks or perhaps in rocks as old as Pennsylvanian. Upward migration along faults, fractures, and joints has transported the oil into the thick porous sandstones of the uppermost Permian and Lower Triassic. In the Circle Cliffs area, oil now in the massive middle Moenkopi sandstones (Triassic) may have originated in the organic lower Moenkopi and upper Kaibab Limestone (Permian), migrating upward via faults, fractures, and joints. The trap is a combination of the broad folding of the Circle Cliffs uplift and stratigraphic variations in the middle Moenkopi sandstones. The Mexican Hat deposit, San Juan County, occurs in Pennsylvanian rocks. The Rozel Point deposit occurs in Recent sediments along the north shore of the Great Salt Lake. Author's text condensed.

Ritzma, H. R., 1969, Oil-impregnated sandstone deposits of Utah - A progress report: Interstate Oil Compact Comm. Committee Bull., v. 11, no. 2, p. 24-34.

The number of known oil-impregnated sandstone deposits in Utah now stands at 40 . Several deposits previously counted have been eliminated as nonexistent; a number of similar minor deposits have been grouped together; and others have been combined as single, large deposits. In Tertiary time, Utah was the site of some of the giant oil fields of the world. Erosion has reduced them to giant deposits of zero-pressure oil-impregnated sandstone. The gross oil in place in these deposits is huge - totaling 12 to 15 billion barrels. This report includes maps, cross sections, and reserve estimates for the major deposits of Utah.

Robeck, R. C., 1954, Uranium deposits of Temple Mountain [Utah], in Geology of portions of the high plateaus and adjacent canyon lands, 
central and south-central Utah: Intermountain Assoc. Petroleum Geologists Guidebook, 5th Ann. Field Conf., p. 110-111.

Petroleum residue (asphalt) in sandstone appears to be polymerized to asphaltite, although accumulations of viscous petroleum have also been found at several places in Temple Mountain. Author's text condensed.

Robinson, H. M., 1917, Ozokerite in central Utah: U.S. Geol. Survey Bull. 641-A, p. 1-16.

The ozokerite of central Utah is found in fissures and brecciated zones caused by the fracturing of the rocks. This fracturing has produced joints and small faults, most of which are nearly vertical. The principal fissures trend N. $10^{\circ} \mathrm{W}$. and contain the largest deposits of ozokerite in the field. The ozokerite and the walls of the fissures commonly show slickensided surfaces. Some of the veins of ozokerite have a width about equal to that of thick paper, a condition which implies a somewhat fluid state of the material at the time of impregnation and suggests that the substance which first filled the fissures was a petroleum that was rich in paraffin. The petroleum from which the ozokerite was derived may have had two sources. It may have been derived from the overlying oil shale and (or) it may have been forced up from lower beds. Author's text condensed.

Schick, R. B., 1966, Drillers probing Utah's French Seep area: Oil and Gas Jour., v. 64 , no. 6 , p. 134-136.

The French Seep area in southern Utah is being core drilled by several major oil companies to evaluate its potential for thermal recovery. Shallow sandstones of the White Rim Sandstone Member of the Cutler Formation (Permian) have heavy-oil-saturated zones that range in thickness from 50 to 300 feet and extend over a wide area. Numerous faults are present; they likely played a strong part in the oil accumulations in the White Rim Sandstone Member. The author calculates recoverable reserves to be 49,000 barrels per acre for a typical producing interval that averages 100 feet thick. This amounts to $30,424,000$ barrels of recoverable reserves for each 640 -acre tract. If the proposed pilot steam floods prove successful, huge new reserves will be opened at French Seep. Author's text condensed.

Shea, G. G., and Higgins, R. V., 1952, Separation and utilization studies of bitumens from bituminous sandstones of the Vernal and Sunnyside, Utah, deposits: U.S. Bur. Mines Rept. Inv. 4871, 28 p.

The hot-water separation process consists mainly of three operations: (1) displacing the bitumen from the sand grains by heating and mixing the bituminous sandstone with water and, if necessary, with enough alkaline reagent to neutralize any acidity present; (2) separating the oil froth from the sand by submerging the pulp in hot water; and (3) removing the water, sand, and silt from the oil froth by means of settling and the use of a light oil. Part 1 of this report summarizes the general characteristics of the Vernal and Sunnyside deposits and discusses the hot-water separation process, as applied to these deposits, and the results obtained. The sandstones respond to treatment by the hot-water method of separation. The bitumen in the Vernal sandstone was extracted more readily by the action of hot water than was the bitumen at Edna, Calif. (Shea, 1948). Recovery of bitumen from the Vernal sandstone was about 96 percent. The Sunnyside sandstone is an 
extremely hard asphalt rock; it must be crushed into small particles before the hot-water treatment can be successfully applied. The disintegrated sand from Sunnyside was fine and contained a high percentage of silt, which increased the loss of bitumen in the tailings discharged from the plant. About 90 percent of the original bitumen in the Sunnyside sandstone was recovered. Part 2 of this report gives analytical data on the recovered bitumen, which was found to contain very little paraffin wax and sulfur, but considerable amounts of nitrogen.

Slentz, L. W., and Eardley, A. J., 1956, Geology of the Rozel Hills, in Geology of parts of northwestern Utah: Utah Geol. Soc. Guidebook to the geology of Utah, no. 11, p. 32-40.

The Rozel Hills area lies along the north shore of the Great Salt Lake, west of Promontory Range, and is represented, for the most part, by a group of low-lying basalt-capped hills. The area has received considerable attention because of the asphalt seeps just off Rozel Point, which were known before the turn of the century. The oil issues from craterlets whose cones are about 12-18 inches high and 20-40 feet in diameter. The oil appears in two forms: (1) numerous globules $1 / 4-1 / 2$ inch in diameter in patches several square feet in area, and (2) stringers of viscous, but fresh, oil emerging from the center of the craterlets, which stretch out as they are buoyed up and finally break and float on the salt-water surface. Carbon-14 dating yields an age of 4,000 years; if this date is correct, the oil would seem to have come from the modern lake sediments, and not from the Pleistocene or Tertiary beds. Authors' text condensed.

Spieker, E. M., 1930, Bituminous sandstone near Vernal, Utah: U.S. Geol. Survey Bull. 822-C, p. 77-98.

Asphalt Ridge, 3-4 miles southwest of Vernal, Utah, contains beds of bitumen-saturated sandstone. Most of these beds are of Eocene age and belong to the Uinta formation, but a few may belong to the Mesaverde formation of Cretaceous age. Analyses showed the bitumen content of the sandstone to range from about 8 percent to a little more than 15 percent by weight. On the basis of these data and the assumption that the sandstone can be mined for $1 \frac{1}{2}$ miles from the outcrop, the whole area examined is estimated to contain about 1.175 billion cubic yards, or about 1.970 billion tons of bituminous rock. Author's abstract condensed.

Steed, R. H., 1954, Geology of Circle Cliffs anticline, in Geology of portions of the high plateaus and adjacent canyon lands, central and south-central Utah: Intermountain Assoc. Petroleum Geologists Guidebook, 5th Ann. Field Conf., p. 99-102.

The Circle Cliffs anticline occupies an area approximately 15 miles wide, from Kane County on the south through east-central Garfield County to the Wayne County line. Locally, the Shinarump sands are saturated with hydrocarbon. Conspicuous saturation can be observed in a lens in Muley Twist Canyon, where it enters the Waterpocket fold. Saturation also occurs at a seep northeast of The Peaks. The middle sandstone member of the Moenkopi formation displays conspicuous oil saturation over most of the southern part of the anticline. The oil saturation in the Kaibab formation occurs as black inflammable hydrocarbon-filled vugs and pore spaces in the upper limestone 
member at The Peaks. Some oil saturation also occurs in the basal 100 feet of the White Rim sandstone member of the Cutler formation. Author's text condensed.

Taff, J. A., and Smith, C. D., 1906, Ozokerite deposits in Utah: U.S. Geol. Survey Bull. 285-H, p. 369-372.

The only known deposits of ozokerite in Utah are in the north end of the Wasatch Plateau. This mineral wax occurs in three localities - (1) in the vicinity of Colton, 7 miles southeast of Soldier Summit, on the north side of the Price River Valley; (2) near but east of Soldier Summit; and (3) near Midway, 3 miles west of Soldier Summit, near the source of Soldier Creek. The ozokerite deposits occur in shales, shaly sandstones, and limestone strata in the lower part of the Tertiary deposits of the "Wasatch" group. The deposits have been found at various stratigraphic levels in a thickness of about 500 feet of rocks. The strata are intersected by fissures and zones of brecciation and parallel jointing. These fissures and spaces between brecciated rock contain the ozokerite, commonly as thin films and sheets, but locally as dikelike bodies several inches thick. The faces of the fissures and the brecciated parts of the rock show the effects of movement on slickensided surfaces. Authors' text condensed.

Untermann, G. E., and Untermann, B. R., 1964, Geology of Uintah County, Utah: Utah Geol. and Mineralog. Survey Bull. 72, 112 p. [p. 91-95].

Production of gilsonite is approximately 450,000 tons annually, mainly by the American Gilsonite Co. at Bonanza. Gilsonite reserves are estimated to be less than 20 million tons. Deposits occur in the Green River, Uinta, and Duchesne River Formations. Gilsonite yields $4 \frac{1}{4}$ barrels of crude oil per ton. Bituminous sandstones along Asphalt Ridge are estimated, by the Bureau of Mines, to contain 2-3 billion barrels of bitumen. These sandstones occur in the Rim Rock Member of the Mesaverde Formation and at the base of the overlying Duchesne River Formation. Covington (1957) believed that the asphalt is closely associated with, and apparently migrated upward along, the Cretaceous-Tertiary unconformity, where the richest saturation of beds occurs. This migration is believed to have taken place in late or post-Oligocene time, and upward movement may still be in progress, inasmuch as late Quaternary or Recent gravels have been cemented by the tarry material. Authors' text condensed.

Wenger, W. J., Hubbard, R. L., and Whisman, M. L., 1952, Analytical data on asphalt properties and cracked products of the separated bitumens, pt. 2, in Separation and utilization studies of bitumens from bituminous sandstones of the Vernal and Sunnyside, Utah, deposits: U.S. Bur. Mines Rept. Inv. 4871, p. 11-28.

Analyses show the bitumens to be mainly high-boiling material. Less than 14 percent of each bitumen distilled below $572^{\circ} \mathrm{F}\left(300^{\circ} \mathrm{C}\right)$ at an absolute pressure, or 40 millimeters of mercury. Sulfur content of the bitumens was 0.50 percent for Sunnyside and 0.39 percent for Vernal, in contrast with 3.20 percent found in the Edna, Calif., bituminous sandstone, and 2-5 percent found in the black oils from the Western States. Nitrogen content in the bitumen was 1.18 and 0.96 percent, respectively, for the Vernal and Sunnyside deposits. These values are slightly less than the 1.23 percent nitrogen in the 
Edna, Calif., bitumen, and are much greater than the 0.2 to 0.4 percent nitrogen found in the typical black-crude oils.

Wengerd, S. A., 1955, Geology of the Mexican Hat oil field, San Juan County, Utah, in Geology of parts of Paradox, Black Mesa, and San Juan Basins: Four Corners Geol. Soc. Guidebook, 1st Field Conf., p. 150-163.

The Mexican Hat oil field has produced relatively small quantities of oil under low pressure, and without appreciable quantities of gas, from at least eight lentils in the Rico and Hermosa formations. The fact that numerous oil seeps occur in the San Juan Canyon virtually proves that an entrenching river will release oil from a reservoir by direct breaching, or by crossing minor faults that transect a reservoir. The discontinuous nature of porosity in these high-shelf Rico and Hermosa reservoir strata militates against a regional draining of the reservoirs, which stand above the present level of the San Juan River. Author's text condensed.

Wiley, D. R., 1967, Petrology of bituminous sandstone in the Green River Formation, southeastern Uinta Basin, Utah: Utah Univ. unpub. M.S. thesis, $69 \mathrm{p}$.

The bituminous sandstones of the Green River Formation are dominantly arkoses. Feldspars constitute $19-60$ percent of the total mineral content, and many of the thin sections were found to contain both fresh and altered feldspars of the same species, indicating that the arkose was tectonically derived. Quartz is the dominant mineral in most samples studied. The bituminous sandstones studied are very heterogeneous. The gross textures and lithologies are extremely varied. The abrupt changes in texture within short, vertical stratigraphic intervals possibly indicate an intermittent turbulence. The effect of variation in texture is demonstrated by the amount of bitumen that a sample contains. Analysis of the two independent variables - the median diameter of the grains and the percentage of clay- and silt-size material shows both to be equally effective in determining the amount of bitumen which the sediment can hold. The most heavily saturated sandstones were those whose grain size was between $4 \mathrm{phi}$ and $2 \mathrm{phi}$, and whose percentage of clay- and silt-size material was low. The original carbonate-cement content has also greatly influenced the bitumen content of the sandstone by reducing the porosity. The sediments comprising the bituminous sandstones probably came from the south and southeast of the area studied, perhaps from the Uncompahgre uplift and the mountains of western Colorado. Author's abstract condensed.

Winchester, D. E., 1919, Oil shale of the Uinta Basin, northeastern Utah: U.S. Geol. Survey Bull. 691-B, p. 51-55.

Hydrocarbon materials filling fissure veins are common in the Uinta Basin. of the different varieties, gilsonite, elaterite, tabbyite, albertite, wurtzilite, and nigrite are asphaltic materials, and ozokerite is a paraffin type. In this region ozokerite occurs only as veins that cut rocks of the Wasatch formation, which is older than the oil shale. The asphaltites are found chiefly in veins that cut beds younger than the oil shale, and all are in the Green River formation or younger formations. The author believes that the oil shales of the Green River formation may be the source of all vein hydrocarbons of the Uinta Basin, as well as of the asphaltic material that saturates certain sandstones of the region. Author's text condensed. 
Woodruff, E. G., and Day, D. T., 1915, Oil shale of northwestern Colorado and northeastern Utah: U.S. Geol. Survey Bull. 581-A, p. 1-21 [p. 16].

Contains measured section of the lower part of the Green River formation at the Black Dragon mine, Dragon, Utah.

\section{WEST VIRGINIA}

Author List

Grimsley, G. P., 1910, Pleasants, Wood, and Ritchie Counties, West Virginia: West Virginia Geol. Survey County Repts., 348 p. [p. 244].

The asphalt deposit at the Ritchie mines, 2 miles northeast of Macfarlan, Ritchie County, was discovered in 1852 and was worked intermittently until 1904. In 1910 open vertical fissures from which the asphalt had been removed, were visible. Mr. Henry Wurtz, a New York chemist, made a report on this deposit in 1865 for the Ritchie Mineral Resin \& Oil Co. Mr. Wurtz stated that the vein extended for a lateral distance of 3,172 feet, and that its width was 30 inches at the east end and 8 inches at the west end. He estimated the quantity of grahamite to be 2,000 tons for every 6 feet of depth. Mr. Wurtz named this mineral grahamite after Mr. Graham, the owner of the Ritchie Mineral Resin \& Oil Co. The specific gravity of grahamite is 1.145 . It is not soluble in alcohol, is partially soluble in naphtha, and is soluble in chloroform or in sulfate of carbon.

\section{WYOMING}

Subject Index

Analyses

Hail, W. J., Jr., 1957

Asphalt deposits

Beaver Divide-Gas Hills area

Van Houten, F. B., and Weitz, J. L., 1956

Bighorn Basin

Washburne, C. W., 1908

Bighorn Mountains

Darton, N. H., 1906

Dallas oil field

Krampert, E. W., 1948

Thompson, R. M., Troyer, M. L., White, V. L., and Pipiringos, G. N., 1950

Douglas oil field

Barnett, V. H., 1914

Biggs, Paul, and Espach, R. H., 1960a

Dutton Basin

Van Houten, F. B., and Weitz, J. L., 1956

Lander oil field

Thompson, R. M., Troyer, M. L., White, V. L., and Pipiringos, G. N., 1950

Woodruff, E. G., and Wegemann, C. H., 1911

Moorcroft oil field

Barnett, V. H., 1915 
Asphalt deposits - Continued

Natrona County

Biggs, Paul, and Espach, R. H., 1960b

Powder River oil field

Wegemann, C. H., 1912

Rattlesnake Mountains

Jamison, C. E., 1911

Trumbull, L. W., 1913

Regional

Ball Associates, Ltd., 1965

Bartram, J. G., 1926

Jamison, C. E., 1911

Trumbull, L. W., 1913

Veatch, A. C., 1907

Sage Creek field

Espach, R. H., and Nichols, H. D., 1941

Salt Creek oil field

Wegemann, C. H., 1918

Woodruff, E. G., and Wegemann, C. H., 1911

Upton-Thornton oil field

Hancock, E. T., 1921

Oil seeps

Barnett, V. H., 1914

Barnett, V. H., 1915

Biggs, Paul, and Espach, R. H., 1960b

Darton, N. H., 1904

Darton, N. H., 1906

Hares, C. J., 1916

Ricketts, L. D., 1890

Tourtelot, H. A., 1953

Trumbull, L. W., 1913

Van Houten, F. B., and Weitz, J. L., 1956

Veatch, A. C., 1907

Uranium

Woodruff, E. G., and Wegemann, C. H., 1911

Vein deposits

Hail, W. J., Jr., 1957

Jamison, C. E., 1911

\section{Author List}

Ball Associates, Ltd., compiler, 1965, Wyoming, in Surface and shallow oilimpregnated rocks and shallow oil fields in the United States: U.S. Bur. Mines Mon. 12, p. 354.

Wyoming contains several large deposits and a large number of lesser occurrences of petroleum-impregnated outcropping rock. The greatest concentration is in the Wind River Basin, central Wyoming; other notable concentrations are on the flanks of the Black Hills, in northeastern Wyoming, and in the Powder River Basin. Author's summary condensed.

Barnett, V. H., 1914, The Douglas oil and gas field, Converse County, Wyoming: U.S. Geol. Survey Bull. 541-C, p. 49-88. 
At several localities in the Douglas field, oil finds its way to the surface in the form of seeps or springs. About 1894, while a tunnel was being dug for an irrigation ditch in the NW1/4 sec. $16, \mathrm{~T}, 32 \mathrm{~N}$., R. $73 \mathrm{~W}$., a sandstone at the top of the Cloverly formation was penetrated and found to be saturated with oil. At another place, in sec. 6, T. 32 N., R. 74 W., in the bed of Boxelder Creek, oil seeps from the top of the Casper formation appeared on the surface of the water. There are two grades of oil in the Douglas field. One is a heavy oil having a specific gravity of 0.9309 to 0.9743 , and the other is a comparatively light oil having a specific gravity of 0.8439 . This suggests different horizons or, at least, different conditions of accumulation. The light oil is probably held in a reservoir that was formed either by a small anticline, which is suggested by the curve in the outcrop of the Cloverly and Chugwater formations, or by the younger, overlying White River formation, which is impervious to oil, owing to its water-saturated condition. The heavy oil is from wells near the seeps and, also, near a fault; hence, the lighter elements of the oil may have escaped, leaving only the heavier fractions. Author's text condensed.

Barnett, V. H., 1915, The Moorcroft oil field, Crook County, Wyoming: U.S. Geol. Survey Bull. 581-C, p. 83-104.

The Moorcroft oil field is on the extreme west edge of the Black Hills uplift. The structure of the rocks in this field is monoclinal, with a general westward dip. At several localities in the Moorcroft field, the oil rises to the surface in the form of seeps or springs. Of the 65 seeps and wells described, three are oil springs, 21 are shallow holes (which should not be considered wells), and 41 are wells that are "fair" tests for oil at the localities where they were drilled. Of the 41 test holes, 15 are reported to have struck showings or small quantities of oil. All but seven of the wells have been abandoned as oil wells. The oil in Bird Oil spring, in sec. 2, T. 51 N., R. 67 W., comes to the surface from the friable sandstone of the Fuson shale (Lower Cretaceous). This spring is so named because the birds that bathe in this spring get the oil on their feathers and are unable to fly away. In the side of the draw, slightly above the spring, there is a bed of very tough, impure asphalt about 8 inches thick. Author's text condensed.

Bartram, J. G., 1926, Occurrence of black oil in Wyoming: Am. Assoc. Petroleum Geologists Bull., v. 10, no. 4, p. 443-448.

The black oil fields of Wyoming, which produce from the Embar and Tensleep formations of Permian-Pennsylvanian age, are found in a small area in west-central Wyoming. The Embar formation is apparently the source of the oil. The black oil has an asphalt base, an average gravity of about $22^{\circ}$ Baumé, and a gravity range of $15^{\circ}$ to $32^{\circ}$. Author's text condensed.

Biggs, Paul, and Espach, R. H., 1960a, Douglas field, in Petroleum and natural gas fields in Wyoming: U.S. Bur. Mines Bull. 582, 538 p. [p. 90].

The Douglas field, known also as the Brenning field, in Brenning Basin, is in the north half of T. 32 N., R. 73 W., Converse County. The White River formation of Tertiary age unconformably overlaps the Cretaceous beds, which apparently are monoclinal, dipping $20^{\circ}-30^{\circ} \mathrm{N}$. In 1894 an oil-saturated sandstone (the top of the Cloverly formation) was uncovered in digging an irrigation ditch in the NW1/4 sec. 16, T. 32 N., R. 73 W. From 1902 through 1907, about 60 holes were drilled in the field to depths of about 400 feet. Most of 
the wells yielded small quantities of oil, gas, and water. Authors' text condensed.

Biggs, Paul, and Espach, R. H., 1960b, Oil Mountain, in Petroleum and natural gas fields in Wyoming: U.S. Bur. Mines Bull. 582, 538 p. [p. 193].

The Oil Mountain anticline is in the SE1/4 T. 33 N., R. 82 W., Natrona County. In 1851 oil was discovered on this anticline at a seep, in sec. 28. The seep was "located" and owned by Kit Carson, James Baker, and half-breed Indians, who transported the oil on ponies to the California (Mormon) trail. There it was sold at $\$ 1$ per quart to freighters or to emigrants, who mixed it with flour and used it for axle grease. About 1895 six shallow holes and pits were dug or drilled by "spring pole" near the oil seep, but they were all barren. Authors' text condensed.

Darton, N. H., 1904, Description of the Newcastle quadrangle [WyomingSouth Dakota]: U.S. Geol. Survey Geol. Atlas, Folio 107.

Small supplies of petroleum have been obtained from borings and from two oil springs near the town of Newcastle, Wyo. The oil is very heavy, and, even in its crude state, is a high-grade lubricant. It occurs in a sandstone in the lower part of the Graneros formation that is extensively developed in the Newcastle area. At two localities, the oil oozes from the sandstone and collects in springs. Several attempts have been made to develop the oil sand in its extension underground by means of wells in the region west and southwest of Newcastle, but thus far, these operations have not yielded a large supply of oil. Author's text condensed.

Darton, N. H., 1906, Geology of the Bighorn Mountains: U.S. Geol. Survey Prof. Paper 51, 129 p.

At various localities along the sides of the Bighorn and associated uplifts, some of the sandstones and sandy shales contain petroleum. This material generally appears in only limited amounts in springs or seeps in small valleys. The principal occurrences are on the sides of the uplift that arises east of the South Fork Powder River. Oil springs of small volume occur in the vicinity of Bonanza. The oil in the springs is from a horizon in the lower part of the Colorado. A deposit of asphalt occurs in the Tensleep sandstone, on the west slope of the Bighorn Mountains, in secs. 28, 29, 32, and 33, T. 52 N.. R. 89 W. The thickness is stated to be 6 feet. The material consists mainly of asphalt that is thoroughly mixed with coarse sand. Author's text condensed.

Espach, R. H., and Nichols, H. D., 1941, Sage Creek field, in Petroleum and natural gas fields in Wyoming: U.S. Bur. Mines Bull. 418, 185 p. [p. 86].

The Sage Creek field, also called Shoshone oil field in the early literature, is in T. 1 N., R. 1 W., Fremont County. An oil seepage in the NW1/4 SW $1 / 4$ sec. 35 was first mentioned in 1864 and attracted attention to this structure when drilling was undertaken along the Shoshone anticline. A well, drilled near the oil seepage in 1909 to a depth of 800 feet, yielded some oil at 650 feet from the Chugwater formation, as well as an appreciable flow at 670 feet, so long as it was agitated. Although 10 wells, most of them along the axis of the anticline, were drilled to depths ranging from 713 to 1,958 feet to the Embar, Tensleep, and Amsden formations, none produced oil or gas in 
commercial quantities. What oil was found was a heavy dark-brown asphaltic oil, the same as that obtained in the Dallas dome field. Authors' text condensed.

Hail, W. J., Jr., 1957, Wyoming, in Reconnaissance for uranium in asphaltbearing rocks, Western United States: U.S. Geol. Survey Bull. 1046-E, p. 55-85 [p. 70].

Lenticular beds of highly weathered asphalt-bearing sandstone in the Wasatch formation (Eocene) crop out near Muddy Creek in Carbon County. The asphalt occurs irregularly in a roughly 100-foot-thick section of sandstone. Analyses of samples from the Muddy Creek locality ranged from 0.015 to 0.091 percent uranium in the ash of the extracted oil. The Teapot sandstone member of the Mesaverde formation of Cretaceous age is saturated with asphalt along its outcrop in secs. 4, 5, 9, T. 33 N., R. 87 W., Natrona County. The asphalt-bearing sandstone forms a prominent hogback. Its outcrop extends about a quarter of a mile and has a maximum exposed thickness of about 50 feet. The asphalt is highly weathered and is now represented only by a brown staining throughout the exposed beds. Uranium content in the ash of the extracted oil from the hogback ranged from 0.014 to 0.032 percent. Author's text condensed.

Hancock, E. T., 1921, The Upton-Thornton oil field, Wyoming: U.S. Geol. Survey Bull. 716-B, p. 17-34.

The Upton-Thornton oil field includes two small dome-shaped folds and a small tract that yields oil and is entirely separate from either of these domes. The tract is about 20 miles southeast of the Moorcroft oil field. The Upton-Thornton field as a whole occupies a part of the southwest flank of the Black Hills uplift. The soft sandy shales and relatively pure sandstones of the lowermost part of the Carlile shale are exposed 2 miles northwest of Thornton. These beds are petroliferous throughout and, in some places, are thoroughly saturated with oil. The oil is obtained from a sand, which ranges in thickness from 29 to 47 feet, that lies at depths of 448 to 843 feet. Author's text condensed.

Hares, C. J., 1916, Anticlines in central Wyoming: U.S. Geol. Survey Bull. 641-I, p. 233-279.

Central Wyoming, an area of 5,000 square miles in Natrona and Fremont Counties west of Casper and southeast of Lander, was investigated to ascertain the possibilities of oil; as a result, the Carboniferous and Cretaceous formations which produce oil in other Rocky Mountain fields were found to be well developed in central Wyoming. Locally, oil seeps from these formations. Large quantities of asphaltum occur on Wallace Creek and its tributaries along the east front of the Rattlesnake Mountains, which suggests the existence of an oil pool somewhere to supply the asphaltum - unless (as is possibly the case) the rocks are so eroded as to have allowed all the oil to escape. Note that these exceptional showings of oil along the mountains are almost directly opposite the Wallace Creek fold, and that a line drawn from the middle of the fold to the larger seeps along the mountain would pass close to Phayles Reef, which is highly saturated with oil. These seeps may be related to the Wallace Creek fold, where perhaps the oil is caught. But all formations in this fold below the Teapot sand of the Mesaverde formation, which crops out at Phayles Reef, are too deep to be drilled. Author's text condensed. 
Jamison, C. E., 1911, Asphalt and related bitumens, in Mineral resources of Wyoming: Wyoming Geol. Survey Bull. 1, 95 p. [p. 31].

Beds of asphalt are found along the north side of the Rattlesnake Mountains, and also near the Wind River Agency, Fremont County. Asphalt mixed with coarse sand occurs on the west side of the Bighorn Mountains. Veins of gilsonite and ozokerite are reported from Fremont and Uintah Counties. Asphaltic sandstone has been found in southern Uinta and western Big Horn Counties. Rich bituminous shale is found near Rock Springs and in the Green River valley. Author's text condensed.

Krampert, E. W., 1948, Dallas field, Fremont County, Wyoming: Wyoming Geol. Assoc. Guidebook, 3d Ann. Field Conf., p. 153-155.

Wyoming's first producing oil well was drilled in the Dallas field in 1884 . This well, though now abandoned, produced until just a few years ago and appropriately still bears the designation "No. 1." It was completed to produce black oil of the Chugwater formation from a depth of about 300 feet. Well No. 1 was drilled squarely in the center of an asphalt deposit, covering about half an acre, that had resulted from a live oil seep. Several additional wells were also drilled. Well No. 3 , which was drilled deep enough to strike oil in the Embar at 750 feet, is still producing after 61 years. Author's text condensed.

Ricketts, L. D., 1890, Annual report of the Territorial Geologist to the Governor of Wyoming: Cheyenne Daily Leader, Steam Book Press, 80 p.

At a number of points between Salt and Oil Creeks, in T. 45 N., Rs. 61 and $62 \mathrm{~W}$., a prominent stratum of sandstone shows indication of petroleum. This stratum may be at the top of the Dakota or, more probably, at the base of the Colorado group of Cretaceous rocks. The petroleum is found at many points as a strain; at others, the oil saturates the sandstone so heavily that it seeps forth to form "springs." The largest spring is in the SW1/4 NE $1 / 4$ sec. 25 , T. 45 N., R. 62 W. The oil in this spring drains from a porous sandstone of the Colorado group of rocks. The spring yields several gallons per day of oil having a density of $22 \frac{1}{2^{\circ}}$ Baumé.

Thompson, R. M., Troyer, M. L., White, V. L., and Pipiringos, G. N., 1950, Geology and oil possibilities of the Lander area, central Wyoming: U.S. Geol. Survey Oil and Gas Inv. Map OM-112, with text.

The Lander (Hudson) anticline is located east and north of the town of Lander. First oil production from the field was in 1912, and shallow-well $(<2,000 \mathrm{ft})$ development is continuing. In early 1949 about 25 wells were producing 350 barrels of oil per day from the Tensleep sandstone and the Phosphoria formation. The first producing well in Wyoming was drilled in 1884 on the Dallas dome. This well, near the center of the dome, was drilled to a depth of 300 feet and produced oil for 60 years before it was abandoned. The Dallas dome field has produced more black oil per surface acre than any other field in the State. More than 60 wells have been drilled, about one-third of which are pumping from the "Embar" and Tensleep. The Derby field is an old shallow field that was discovered somewhat later than the Dallas field. It has produced small amounts of black oil steadily for many years from the Phosphoria formation and Tensleep sandstone. Authors' text condensed. 
Tourtelot, H. A., 1953, Geology of the Badwater area, central Wyoming: U.S. Geol. Survey Oil and Gas Inv. Map OM-124, with text.

The presence of oil and gas in the Badwater area is indicated by oil-stained rocks exposed on the surface and shows of oil and gas discovered in drilling wells. Some of the more evident surface indications are the oil seeping from the Flathead sandstone in the SW1/4 NE1/4 sec. 6, T. 39 N., R. 91 W.; oil staining in the Frontier formation in sec. 23 , T. $38 \mathrm{~N}$., R. $87 \mathrm{~W}$.; oil staining in the Cretaceous or Tertiary rocks in sec. 10, T. 39 N., R. 91 W., and oil staining in the andesite-tuff sequence at several places. Water wells 300-500 feet deep, drilled near Lost Cabin, have also tapped small amounts of gas. Drilling has also yielded small amounts of a heavy black oil, having an API gravity of $33.7^{\circ}$, from a depth 933 feet. Author's text condensed.

Trumbull, L. W., 1913, Prospective oil field at Upton, Weston County; Buck Creek, Niobrara County; Rattlesnake Mountains, Natrona County; and La Barge, Lincoln County: Wyoming Geol. Survey Bull. 5, 15 p.

The Rattlesnake oil field is on the northeast flank of the Rattlesnake Mountains, in southwest Natrona County. Along the outcrops of Cretaceous rocks (from Dakota to Mesaverde) deposits of asphaltum mark the location of former oil springs, and at many places oil-saturated sandstones form prominent ridges. The oil seepages and springs of the Rattlesnake region have been recognized for over 40 years, and at various times efforts have been made to develop the field. As a result, many pits and shallow wells have been drilled, but no deep wells have been drilled. The La Barge oil field, in Lincoln County, is on the west side of the Green River and north of La Barge Creek. In 1907 oil was discovered seeping from the Tertiary sandstones on the flat east of La Barge Mountain. Since then, many prospect holes have been drilled; however, none go down more than 1,000 feet, and oil in quantity has not been found. The oil is heavy and dark, and has a density of $18.75^{\circ}$ Baumé. Author's text condensed.

Van Houten, F. B., and Weitz, J. L., 1956, Geologic map of the eastern Beaver Divide-Gas Hills area, Fremont and Natrona Counties, Wyoming: U.S. Geol. Survey Oil and Gas Inv. Map OM-180, with text.

Five areas of surface oil staining or gas seeps are known from the Dutton Basin anticline, indicating the presence of at least small amounts of oil and gas in the structure. In the authors' opinion, the mineral-fuels potential of the Dutton Basin anticline has not been adequately explored. Authors' text condensed.

Veatch, A. C., 1907, Geography and geology of southwestern Wyoming, with special reference to coal and oil: U.S. Geol. Survey Prof. Paper 56, 178 p. [p. 139-162].

Oil has been found in southern Uintah County in springs at Hilliard Flat 一 the Brigham Young Oil Spring, in sec. 4, T. 13 N., R. 119 W., and the White Oil Spring, in sec. 33, T. 14 N., R. 119 W. - at Aspen tunnel, in sec. 12, T. 14 N., R. 119 W., and in sec. 7, T. 14 N., R 118 W.; 3 miles north of Aspen tunnel, in Carter Oil Spring, in sec. 31, T. 15 N., R. 118 W.; in springs and wells on the south branch of Twin Creek, in T. 21 N., R. 117 W.; and in wells near Spring Valley, in Tps. 14 and 15 N., R. 118 W. These springs all occur in the region of profound disturbance along the Absaroka fault. The 
Brigham Young, White, and Carter Oil Springs occur along a secondary fault just east of the main faultline. This oil-spring fault cuts the west end of the Aspen tunnel, and the oil seepage in this tunnel is believed to be of the same character as that in neighboring oil springs. The oil issues from faulted Cretaceous rocks of Benton age. In the Fossil (town) area, the oil comes from a group of springs that, with the exception of globules of oil, are of the type commonly found in the Eocene beds. The oil from the Brigham Young, White, Carter, and Fossil Oil Springs and from nearby wells is dark and heavy, and perhaps has been derived from the Aspen oils by evaporation of its more volatile constituents. Author's text condensed.

Washburne, C. W., 1908, Gas fields of the Bighorn Basin, Wyoming: U.S. Geol. Survey Bull. 340-F, p. 348-363.

The Madison limestone in Sheep Canyon, 15 miles north of the basin, shows many signs of oil. The rock is black in places from the contained carbonaceous material and has a distinct oily smell when freshly broken. Asphaltum, or other solid hydrocarbons, filling many of the small cavities and fissures in the Madison limestone is further proof of the existence of oil in that rock. A bed of asphalt mixed with sand and rock was filed on, for the purpose of quarrying the asphalt, in T. 42 N., R. 90 W. The asphalt occurs in "blanket" form as a bed, 10 feet thick, on a hilly surface of limestone or sandstone. About half of the bed is reported to be asphalt; the remainder is reported to be sand and rock, which the asphalt binds together in a firm mass. Apparently, the asphalt has exuded from the Pennsylvanian rocks at this place and cemented the base of the rock mantle. That such a large deposit of asphalt occurs is a strong indication that oil is present in the upper Paleozoic strata. Author's text condensed.

Wegemann, C. H., 1912, The Powder River oil field, Wyoming: U.S. Geol. Survey Bull. 471-A, p. 56-75.

Practically all indications of oil in the Powder River Basin occur in T. 41 N., R. 81 W., and in the northern part of T. 40 N., R. 81 W. The distribution of the oil is controlled by a structural dome resembling that of the Salt Creek oil field, 15 miles to the southeast. The oil of the Powder River field is used as a heavy lubricating oil; it is black and contains over 2 percent asphalt and about 20 percent kerosene, but no naphtha. The principal reservoir is the coarse conglomeratic sandstone, 56 feet thick, in this report called Dakota. Author's text condensed.

Wegemann, C. H., 1918, The Salt Creek oil field, Wyoming: U.S. Geol. Survey Bull. 670, $52 \mathrm{p}$.

The Salt Creek field is about 7 miles square in Tps. 39 and 40 S., R. 79 W., 40 miles north of Casper and 30 miles southeast of the foot of the Bighorn Mountains. Surface indications of oil in the Salt Creek field include oil and gas seeps in the shale, deposits of ozokerite or mineral wax along the fault planes in the shale, and oil seeps from the Shannon sandstone. At many places, layers of ozokerite, or mineral wax, $1 / 8-1 / 2$ inch thick, are associated with the calcite-filled fault fissures in the shale. The mineral wax is black, presumably because it contains a small amount of asphalt. This wax, which is found at the surface in fissures that doubtless contain oil below the surface, appears to be the residue left by the evaporation of the oil. Oil seeps from 
the Shannon sandstone itself in at least three places on the rimrock at the north end of the Salt Creek dome. Author's text condensed.

Woodruff, E. G., and Wegemann, C. H., 1911, The Lander and Salt Creek oil fields, Wyoming: U.S. Geol. Survey Bull. 452, 87 p. [p. 7-34].

Oil springs, together with the favorable anticlinal structure, led to prospecting for oil in the Lander area. The oil springs are seeps from which only small amounts of oil flowed. In two of the springs the oil is a heavy asphaltic variety; when it reaches the surface, the lighter parts evaporate and leave the asphalt to impregnate the soil. Although oil has been found in several formations, its occurrence is believed to be controlled by structure, because, so far as is known, oil only occurs near the crest of an anticline. The oil is dark brown and flows readily from the wells. It becomes slightly thicker on exposure to the air for several weeks. Samples from six wells were analyzed and found to contain from 4.02 to $\mathbf{1 5 . 2 6}$ percent asphalt. 


\section{CANADA}

SUBJECT INDEX

\section{Cretaceous}

Ball, M. W., 1935

Ball, M. W., 1941

Bell, Robert, 1885

Cameron, E. M., 1965

McMurray Formation

Alberta Society of Petroleum Geologists, 1951

Ansley, R. W., and Biermeier, W. G., 1963

Ball, M. W., 1941

Bellows, L. A., and Bohme, V. E., 1963

Carrigy, M. A., 1959a

Carrigy, M. A., 1959b

Carrigy, M. A., 1962

Ellison, A. H., 1959

Falconer, W. L., 1951

Government of Alberta, 1951

Gussow, W. C., 1941

Gussow, W. C., 1956

Hume, G. S., 1933

Hume, G. S., 1944

Hume, G. S., 1951

Kidd, F. A., 1951

Mellon, G. B., 1956

Mellon, G. B., and Wall, J. H., 1956

Research Council of Alberta, 1955

Dakota formation

Ells, S. C., 1914

Huntley, L. G., 1916

McConnell, R. G., 1893

Exploration

Gallup, W. B., 1960

Geochemistry

Bowman, C. W., 1967

Boyd, M. L., and Montgomery, D. S., 1961

Boyd, M. L., and Montgomery, D. S., 1962

Boyd, M. L., and Montgomery, D. S., 1963

Cameron, E. M., 1965

Carrigy, M. A., 1959a

Carrigy, M. A., 1962

Carrigy, M. A., 1967

Clark, K. A., 1957

Clark, K. A., 1960

Clark, K. A., and Blair, S. M., 1925 
Geochemistry - Continued

Goodspeed, F. E., and Montgomery, D. S., 1962

Hardy, R. M., and Hemstock, R. A., 1963

Hodgson, G. W., and Baker, B. L., 1959

Krieble, V. K., and Seyer, W. F., 1921

Nagy, B., and Gagnon, G. C., 1961

Round, G. F., 1960

Schrayer, G. J., Weismann, T. J., and Zarrella, W. M., 1960

Ward, S. H., and Clark, K. A., 1950

Warren, T. E., 1951

Warren, T. E., Booth, F. L., Carson, R. E., and Bowles, K. W., 1951 Metals associated with crude oils

Hodgson, G. W., Peake, Eric, and Baker, B. L., 1963 Iron

Hodgson, G. W., 1954

Nickel

Scott, Jean, Collins, G. A., and Hodgson, G. W., 1954

Hodg'son, G. W., 1954

Scott, Jean, Collins, G. A., and Hodgson, G. W., 1954

Vanadium

Hodgson, G. W., 1954

Scott, Jean, Collins, G. A., and Hodgson, G. W., 1954

Mining and recovery

Alberta Society of Petroleum Geologists, 1951

Bellows, L. A., and Bohme, V. E., 1963

Birchard, J. A., Bowman, C. W., Butler, R. M., and Tiedje, J. L., 1963

Brusset, M. J., Edgington, A. N., and Gilmour, R. F., 1967

Clark, K. A., 1944

Clark, K. A., 1950

Clark, K. A., 1960

Clark, K. A., and Alexander, E. L., 1951

Clark, K. A., and Pasternack, D. S., 1932

Cottrell, J. H., 1963

Davis, C. M., 1951

Djingheuzian, L. E., 1951

Dor, A. A., Daly, W. J., Floyd, P. H., and Hall, F. T., 1967

Doscher, T. M., 1967

Doscher, T. M., Labelle, R. W., Sawatsky, L. H., and Zwicky, R. W., 1963

Gibbon, Anthony, 1957

Gold, Otto, 1967

Gussow, W. C., 1941

Haliburton, James, 1947

Hitchon, Brian, Round, G. F., Charles, M. E., and Hodgson, G. W., 1961

Hodgson, G. W., Matchen, Ben, Peterson, W. S., and Gishler, P. E., 1952

Hopper, D. A., 1945

Hoskins, A. D., 1964

Innes, E. D., 1967

Larson, V. C., Peterson, R. B., and Lacey, J. W., 1967

Lowell, P. F., Reif, H. E., Burk, R. O., Hertel, P. H., and Abbott, B. T., 1966 
Mining and recovery - Continued

Natland, M. L., 1963

Oil and Gas Journal, 1960

Pasternack, D. S., 1963

Pasternack, D. S., and Clark, K. A., 1951

Pasternack, D. S., Hodgson, G. W., and Clark, K. A., 1951

Peterson, W. S., and Gishler, P. E., 1951

Schellhorn, H. W., 1963

Smoley, E. R., and Schutte, A. H., 1951

Spragins, F. K., 1967

Oil seeps

Cameron, A. E., 1921

Ells, S. C., 1924

Huntley, L. G., 1916

Kleinpell, R. M., 1932

Origin

Link, T. A., 1932

Ball, M. W., 1935

Ball, M. W., 1941

Bell, Robert, 1885

Bellows, L. A., and Bohme, V. E., 1963

Carrigy, M. A., 1963

Conybeare, C. E. B., 1966

Corbett, C. S., 1955

Hitchon, Brian, 1963

Hitchon, Brian, and Shaw, D. R., 1960

Hodgson, G. W., Peake, Eric, and Baker, B. L., 1963

Link, T. A., 1951

Montgomery, D. S., 1951

Sproule, J. C., 1938

Sproule, J. C., 1951

Vigrass, L. W., 1965

Williams, M. Y., 1949

Paleontology

Mellon, G. B., and Wall, J. H., 1956

Russell, L. S., 1932

Principal asphalt deposits

Athabaska

Ball, M. W., 1935

Ball, M. W., 1941.

Kinney, G. T., 1963

Pow, J. R., Fairbanks, G. H., and Zamora, W. J., 1963

Bluesky-Gething

Kinney, G. T., 1963

Pow, J. R., Fairbanks, G. H., and Zamora, W. J., 1963

Grand Rapids

Kinney, G. T., 1963

Pow, J. R., Fairbanks, G. H., and Zamora, W. J., 1963

\section{Regional}

Arctic Islands

Fortier, Y. O., McNair, A. H., and Thorsteinsson, R., 1954

Sproule, J. C., and Lloyd, G. V., 1963 
Regional - Continued

Cold Lake

Webber, H. J., 1967

Ells River

Clark, K. A., and Blair, S. M., 1927

Great Slave Lake

Cameron, A. E., 1921

Hay and Buffalo Rivers

Cameron, A. E., 1921

Hotchkiss East

Von Der Lin, Frances, 1961

Lesser Slave Lake

McConnell, R. G., 1893

MeMurray district

Ells, S. C., 1962

Mildred-Ruth Lakes area

Hume, G. S., 1947b

Peace River

McConnell, R. G., 1893

Vigrass, L. W., 1968

Von Der Lin, Frances, 1961

Peter Pond Lake area

Kupsch, W. O., 1954

Queen Charlotte Islands

Kleinpell, R. M., 1932

Red Earth Northeast

Von Der Lin, Frances, 1961

Reservoirs

Brown, J. S., 1965

Link, T. A., 1951

Resources

Ball, M. W., 1935

Brese, W. G., 1963

Carrigy, M. A., 1959b

Carrigy, M. A., and Zamora, W. J., 1960

Gussow, W. C., 1956

Hume, G. S., 1944

Hume, G. S., 1947a

Kinney, G. T., 1963

Pow, J. R., Fairbanks, G. H., and Zamora, W. J., 1963

Stewart, G. A., 1963

Von Der Lin, Frances, 1961

Sulfur

Webber, H. J., 1967

Brese, W. G., 1963

Clark, K. A., and Blair, S. M., 1925

Huntley, L. G., 1916

Plewes, A. C., 1951 


\section{AUTHOR LIST}

Alberta Society of Petroleum Geologists, 1951, Western Canada, in Possible future petroleum provinces of North America: Am. Assoc. Petroleum Geologists Bull., v. 35, no. 2, p. 169-184.

The oil sands of northern Alberta occur in the McMurray formation, correlated as basal Lower Cretaceous, and lie without angular unconformity on a floor of base-leveled Devonian. The sands are of continental origin and appear to be a great delta swept off the Precambrian shield on the east into the margins of an Early Cretaceous sea. The oil is a heavy viscous tarry crude, extremely sensitive to heat; in an ASTM distillation, cracking begins before the kerosene fraction has distilled over. Its thermal behavior resembles that of a virgin oil, converted only a short way beyond the asphalt stage, rather than that of a residual oil from which the lighter fractions have evaporated. Recent drilling indicates that the oil probably originated in the underlying Devonian. Long porous reef limestone sections have been found in the Devonian, directly overlain by the Cretaceous McMurray sandstone, and both the limestone and the sandstone are impregnated with characteristic "tarsand" oil. The oil envelops each sand grain and occupies the pore spaces. Its removal leaves the sand as free as that on a beach. To recover the oil, the sand must be mined and the oil distilled, dissolved, or washed out with hot water. The hot-water method seems to be the most practicable and economical. Most of the deposit is too deeply buried for mining under present conditions; the workable parts are the benches and interstream areas in the valleys of the Athabaska River and its tributaries, where streams have cut through the overlying beds and into or through the oil sands. The minable areas are estimated to contain at least 1 billion barrels of oil. Author's text condensed.

Ansley, R. W., and Biermeier, W. G., 1963, Continuity of bedding within the McMurray Formation, in Athabaska oil sands: Research Council Alberta Inf. Ser. 45, p. 55-62.

Detailed examination of the outcrop at Mildred Lake, 25 miles north of Fort McMurray, showed that the McMurray Formation contained (in addition to the bituminous sands) thin interbeds of clay and silt and lenses of barren siltstone. In general, the McMurray Formation in the area investigated with closely spaced drill holes can be divided into three parts. The top part consists of thinly bedded clays, silts, and sands, averaging fair to good feed for a commercial plant. The center part consists of interbedded clays, silts, and sands and could be considered undesirable or marginal feed. The basal part consists of massive sands with few silt and clay beds and is considered good to rich feed. Authors' text condensed.

Ball, M. W., 1935, Athabaska oil sands - Apparent example of local origin of oil: Am. Assoc. Petroleum Geologists Bull., v. 19, no. 2, p. 153-171.

In the debate on local origin versus long-distance migration of oil, some consideration may well be given to the oil sands of northern Canada. Here are many thousands of square miles of oil-saturated sands, containing up to 
100,000 and more barrels of oil per acre. Estimates of the total oil content range from 100 billion to 250 billion barrels. The oil sands seem to lie too flat to have induced oil migration. There is no suggestion of artesian or metamorphic fluid movement into the area from without. The sand appears to be saturated throughout most of its horizontal extent. There seems to be no large additional sand area from which the oil might have migrated, and no deeper porous bed is known which might have brought oil into the area from remote sources. Whether the oil originated in overlying beds and seeped down into the sand, or in underlying beds and migrated upward, or in the sand itself is not definitely known, but evidence suggests that the oil originated in its present position. Author's abstract, slightly modified.

Ball, M. W., 1941, Development of the Athabaska oil sands: Canadian Inst. Mining and Metallurgy Trans., v. 44, p. 58-91.

The oil sands underlie an undetermined part of the great high plains or plateau area that makes up most of northern Alberta. The focal point of the exposures is at Fort McMurray, at the junction of the Athabaska and Clearwater Rivers 300 miles north of Edmonton. The oil sands are generally 100 to 200 feet thick and at some places are as much as 225 feet thick. The beds of richly impregnated sands stand out in bold cliffs. They are composed of fine sand particles enveloped in a film of soft sticky bitumen, which is the sole cementing material. The sand is composed of quartz with relatively small quantities of mica and other material. The McMurray formation, which contains the oil sands, is of continental origin. It lies at the base of the Lower Cretaceous unconformably on the flat surface of the Devonian. Author's text condensed.

Bell, Robert, 1885, Report on part of the basin of the Athabaska River, northwest territory: Canada Geol. Survey, Rept. of Progress for 1882-1884, pt. 5,37 p.

There seems little doubt that the vast quantities of somewhat altered petroleum contained in the soft Cretaceous sandstones of the Athabaska region were derived from the Devonian limestones immediately underlying them. That the petroleum came from below would be expected, in accordance with natural laws. Where the contact of the sandy petroleum-bearing strata with the higher Cretaceous rocks was seen at the Drowned Rapid, it was observed that the oil was prevented from passing upward by tenacious clayey strata. The drift resting on the petroleum-bearing strata did not appear to be impregnated with the oil, an indication that the oil probably saturated the Cretaceous strata as a thin liquid and then became altered to its present state long before the glacial period. Author's text condensed.

Bellows, L. A., and Bohme, V. E., 1963, Athabaska oil sands: Jour. Petroleum Technology, v. 15, no. 5, p. 479-483.

The oil in the McMurray Formation is heavy, viscous, and sulfurous. Specific gravity is from 1.002 to 1.027 , and viscosity ranges from 3,000 to 400,000 poise at $60^{\circ} \mathrm{F}$. The sulfur content is from 4 to 5 percent, and the nitrogen content is about 0.4 percent. The origin of the oil has been explained by a number of different theories. The generally accepted hypothesis is that the oil migrated up from the Devonian limestone. The amount of oil in place is estimated to be over 300 billion barrels, but none is recoverable by natural 
flow. In-situ recovery, using some form of heat or open-pit mining, seems to be the most logical recovery method. Authors' text condensed.

Birchard, J. A., Bowman, C. W., Butler, R. M., and Tiedje, J. L., 1963, Separation of oil from the Athabaska oil sands by sand reduction, in Athabaska oil sands: Research Council Alberta Inf. Ser. 45, p. 171-191.

A process of sand reduction lowers the solids content of the Athabaska oil sand to the extent where direct distillation and coking in a fluidized solids bed may be economically practical. In this process, oil sand is mixed with water at low temperatures, clean sand separates, and the oil particles are released from the structure agglomerate to form an oil phase. The agglomerate is then separated from the solids. The enriched oil phase is processed directly, and water is recycled in the process. The process has the following attractive features: (1) Low operating temperature, (2) good oil recoveries, (3) tolerance to fines in feed and recycle water, (4) no requirements for solvents, and (5) no production of sludge. Authors' abstract condensed.

Bowman, C. W., 1967, Molecular and interfacial properties of Athabaska tar sands: World Petroleum Congress, Proc., 7th, v. 3, p. 583-604.

The bitumen (toluene-soluble portion of tar sand) is a highly viscous organic material with a specific gravity of slightly above 1. Measurable quantities of organic material remain associated with the inorganic matrix after toluene extraction. The water-soluble organic material concentrates at air-water interfaces, where it reduces the surface tension to values as low as 30 dynes $/ \mathrm{cm}$. The major functional group appears to be a metal carboxylate. The "pH-controlling" minerals in the Athabaska tar sands affect the interfacial properties. The presence of calcite, siderite, ferrous hydroxide, and pyrrhotite will increase the $\mathrm{pH}$ and provide a system where the particles are negatively charged and well dispersed. Interfacial tension measurements are limited by lack of reliable data on solid-fluid interfacial tensions. According to incomplete data, some, but not all, of the desired transformations require a high temperature and a high $\mathrm{pH}$. One notable exception is the initial attachment of gas bubbles to bitumen particles. At low pHs, polyvalent metal ions and anionic organic surfactants act as bridging agents between the various phases of tar sand. At higher $\mathrm{pHs}$, the metal ions are precipitated as insoluble hydroxides, the solid surfaces become hydrated, and the anionic surfactants are ionized. The net effect is that all particles in the system become highly charged and well dispersed. Author's conclusions condensed.

Boyd, M. L., and Montgomery, D. S., 1961, A study of the Athabaska bitumen from the Abasand quarry, Alberta, Canada; pt. I, Early history, analysis of the bituminous sand and isolation and structural analysis of the asphaltene fraction: Canada Dept. Energy, Mines and Resources Mines Br. Research Rept. 78, 67 p.

A brief summary of the early history and development of the Athabaska bitumen is given as a background to the present chemical research. The physical properties of the bituminous sand being studied are tabulated; these include elementary analysis, ash content, molecular weight, density at $20^{\circ} \mathrm{C}$, the emission spectra of the ash of the bitumen, and the chemical composition, screen analysis, and emission spectra of the sand. Preliminary chromatographic experiments on the bitumen are described to illustrate the necessity 
of separating the asphaltene components before the remainder of the bitumen is fractionated. The following properties of the asphaltene fraction were measured: Ash content, elementary analysis, molecular weight, density at $20^{\circ} \mathrm{C}$, refractive index at $20^{\circ} \mathrm{C}$, emission spectra of the ash, and the infrared spectrum. The asphaltene fraction is characterized by the application of van Krevelen's structural analysis system and, also, by two new methods, which were devised by the authors. The chemical structure is expressed in terms of five structural groups, and an estimate is made of the degree of condensation of the aromatic rings by determining the number of fusedring and nonfused-ring junction carbon atoms. Authors' abstract.

Boyd, M. L., and Montgomery, D. S., 1962, Chromatographic separation of the oil fraction, and properties and structure of the oil components, pt. III, in A study of the Athabaska bitumen from the Abasand quarry, Alberta, Canada: Canada Dept. Energy, Mines and Resources Mines Br. Research Rept. 104, 67 p.

The oil component, which constituted 33.1 percent of the Abasand bitumen, was resolved into a series of fractions by elution chromatography on silica gel. The saturated fraction was further resolved on activated carbon, and the most aromatic portion was further resolved on both activated carbon and alumina. The following properties were determined for most of the fractions thus prepared: Elementary analysis, molecular weight, density $\left(20^{\circ} \mathrm{C}\right)$, refractive index $\left(n D^{20}\right)$, dispersion, the aniline point, the ultraviolet spectrum, and the infrared spectrum. Quantitative estimates of the number of methyl, methylene and aromatic carbon atoms have been made from the infrared spectra. About one-third of the oil component can be separated out as totally saturated material. The remainder of the material was separated into a series of fractions that contained increasing proportions of aromatic carbon atoms, up to about 35 percent. On the average, the oil fractions would appear to contain three rings per molecule. Authors' abstract condensed.

Boyd, M. L., and Montgomery, D. S., 1963, Composition of Athabaska bitumen fractions, as determined by structural-group analysis methods, in Athabaska oil sands: Research Council Alberta Inf. Ser. 45, p. 101-108.

This paper summarizes the results from determination of the hydrocarbon skeletal structure of Athabaska bitumen fractions, largely by means of structural-group-analysis methods. The bituminous sample used in this investigation, taken from Fort McMurray, Alberta, contained 15.8 percent bitumen by weight. A method of structural-group analysis developed by the authors was applied. The composition was expressed in terms of 5 hydrocarbon groups, or fractions. This method consisted of correlation of the following properties: The elementary composition, molecular weight, density $\left(20^{\circ} \mathrm{C}\right)$, refractive index $\left(n D^{20}\right)$, and aromaticity. The composition of these five fractions ranged from a colorless saturated oil, having a molecular weight of 360 and containing three rings per molecule, to a blackish-brown solid, having a molecular weight 2500 , in which half the carbon atoms were aromatic, and whose molecule contained 23.6 rings. Authors' abstract condensed.

Brese, W. G., 1963, Outlook for the Alberta sulfur industry, in Athabaska oil sands: Research Council Alberta Inf. Ser. 45, p. 231-238.

The Athabaska oil has a sulfur content of approximately 5 percent by weight. Thus, the reserve contains about 1 billion long tons of sulfur. Currently, 
four oil-sand development projects have been proposed and would produce up to 1,600 long tons of sulfur per day. Rather than being a boon to a sulfurstarved world, such massive production of this sulfur could flood the market and, thus, depress the industry. Author's abstract modified.

Brown, J. S., 1965, Formation evaluation in heavy-oil sands: Jour. Canadian Petroleum Technology, v. 4, no. 4, p. 177-187.

The term "formation evaluation" is here used to mean the process of reservoir detection and evaluation. The process of correlation is implicit, as the reservoir must be identified, as well as detected. The area studied includes the oil fields of the Chauvin, Wainwright, and Lloydminster areas of Alberta and Saskatchewan. The principal heavy-oil reservoir is the Sparky sand. At the Wainwright and Chauvin fields reservoir detection is more difficult because the oil sands there are thin and have low apparent resistivities, whereas at Lloydminster, the oil sands are thick and have high apparent resistivities. At Wainwright and Chauvin, a resistivity log, a porosity log, and, commonly, a drill-stem test are necessary for a decision to set pipe; at Lloydminster, only an electrical log is necessary. Productivity varies considerably from pool to pool, probably because of changes in sand permeability and oil viscosity. Author's abstract condensed.

Brusset, M. J., Edgington, A. N., and Gilmour, R. F., 1967, Equipment performance in an Alberta high-pressure steam-injection project: Jour. Canadian Petroleum Technology, v. 6, no. 4, p. 115-122.

During 1966 an experimental steam-injection project was operated cooperatively by the Northwestern Refining Co. and the McWood Corp. at Hughenden, Alberta. The project has shown that it is feasible to inject high-pressure steam (1,500-1,600 pounds per square inch gage) at high rates (22 million Btu per hour) into a sandstone reservoir containing an $18^{\circ}$ API gravity crude oil at a depth in excess of 2,500 feet without experiencing serious mechanical problems and without excessive heat losses. Authors' abstract condensed.

Cameron, A. E., 1921, Hay and Buffalo Rivers, Great Slave Lake and adjacent country: Canada Geol. Survey Summary Report for 1921, pt. B, p. 1-44.

The oil occurrences at Nintsi Point appear as seepages on the exposed surfaces of the oil-bearing horizon. A possible explanation of these seepages is that the sulfur-bearing waters, which carry considerable quantities of calcium and magnesium salts, rise from below and percolate through the overlying thin bedded dolomitic limestones, changing them to crystalline magnesium limestones and dolomites. In the process, bitumen is set free and forced into cavities in the dolomites or is forced through fissures, developed during dolomitization, to the surface, where it forms tar and oil pools. If the above explanation is true of the conditions at Nintsi Point, it would tend to show that the oil seepage there represents only local conditions and that the possibility of a commercially economic oil horizon in the Presqu'ile dolomite is small. However, the oily matter in the cavities in the Presqu'ile dolomites, exposed at Presqu'ile Point and on Burnt Islands, indicates much more extensive oil-bearing conditions and tends to prove that the structural conditions control the concentration of the oil. It is the author's opinion that the oil seepages at Nintsi Point are probably the result of both chemical action and structural conditions. Author's text condensed. 
Cameron, E. M., 1965, Applications of geochemistry to stratigraphic problems in Lower Cretaceous of western Canada: Am. Assoc. Petroleum Geologists Bull., v. 49, no. 1, p. 62-80.

The detrital sediments of the Lower Cretaceous series of the Interior Plains of Western Canada were sampled at close vertical intervals in fourteen widely spaced sections in Alberta and western Saskatchewan. "Chemical logs" were plotted for each section and show that, throughout the study area, the series can be separated into three stratigraphic divisions, each having a distinctive soda content. The lower division is poor in soda. The middle division is composed principally of sediments that are rich in sodic igneous detritus and that interfinger with low-soda strata in the eastern part of the area. The upper division consists of sediments that have a low to intermediate soda content. Samples of different grain size (such as sand samples versus shale samples) share a distinctively similar soda content if they are from the same division, or sediment suite. Throughout the sediment series, however, the potash content of different grain-size samples from any one division varies far more than does the soda content and, as a result, is much less useful as evidence for stratigraphic correlation. Chemical methods of correlating detrital sediments appear to be useful, particularly when applied to shales or to mixed assemblages that include shales. Author's text condensed.

Carrigy, M. A., 1959a, The significance of a grain-size classification of the sands of the McMurray formation, Alberta: World Petroleum Congress, Proc., 5th, v. 1, p. 575-590.

The oil sands of the McMurray formation are divided into three classes on the basis of sieve analyses and outcrop examination. Class I: Coarse to medium sands; samples have a maximum grain size greater than 1 millimeter, a median diameter of not less than 0.13 millimeter, and more than 80 percent of the total weight greater than 0.074 millimeter in size. The deposits of Class I are massive crossbedded sands and conglomerates found at the base of the formation. Their high permeability has allowed secondary enrichment by migrating oil or, as in some places, leaching of all oil. Class II: Fine to very fine sands; samples have a maximum grain size less than 0.3 millimeter, a median diameter between 0.18 and 0.09 millimeter, and more than 80 percent of the total weight greater than 0.074 millimeter in size. The deposits of Class II are clean massive oil sands with good oil impregnation; they are little altered by secondary migration and are commonly found in the middle of the formation. Class III: Very fine sands and silts; samples have a maximum size less than 0.3 millimeter, a median diameter less than 0.12 millimeter, and less than 80 percent of the total weight greater than 0.074 millimeter in size. The deposits of Class III are the horizontally laminated shaly sands found in the upper part of the formation. Because of their low permeability, oil impregnation is poor. The potential usefulness of the classification is illustrated by mapping the distribution of the sands of Class I of the McMurray formation in the subsurface near Fort Mackay and by recognizing the relationship of the coarse sands to the oil impregnation in that area. The sediments of the McMurray formation were deposited in fluvial, lacustrine, paludal, and lagoonal environments. Author's abstract modified.

Carrigy, M. A., 1959b, General geology of the McMurray area, pt. III, in Geology of the McMurray formation: Research Council Alberta Mem. 1, $130 \mathrm{p}$. 
A summary of the estimates of petroleum resources of the oil sands indicated that, in 1958, 1.67 billion barrels had been proved by intensive drilling. An additional 200 billion barrels is a conservative estimate of the quantity of oil underlying the official bituminous sands area. The official bituminous sands area comprises 315 townships and covers an area of 11,340 square miles. Author's text condensed.

Carrigy, M. A., 1962, Effect of texture on the distribution of oil in the Athabaska oil sands, Alberta, Canada: Jour. Sed. Petrology, v. 32, no. 2, p. 312-325.

The Athabaska oil sands consist of uncemented quartzose sand, silt, and clay, impregnated by extremely viscous oil. Seventy-six percent of the variation in the oil content of these sediments is related to the median diameter and to the percentage of clay-size material (less than 2 microns). As the percentage of the clay-size fraction increases, the oil content decreases; but, as the median diameter increases, the oil content increases. Analyses of variance of the two independent variables show that the percentage of claysize material is more effective than the median diameter in determining the amount of oil a sediment can hold. Most of the oil-rich sands in the samples tested had median diameters between 250 microns $(2 \phi)$ and 62 microns $(4 \phi)$ and were thus within the range of grain size of most sandstone reservoir rocks. Author's abstract condensed.

Carrigy, M. A., 1963, Paleocurrent directions from the McMurray Formation: Bull. Canadian Petroleum Geology, v. 11, no. 4, p. 389-395.

Grain-size analyses of the crossbedded sands of the McMurray Formation show that most of them are well-sorted sands of various grain size. The wellsorted nature of the sands suggests that they represent the load carried by a current of uniform velocity. The high angle of the dip, the wide variation in dip azimuths for the crossbeds, and the good degree of sorting of the crossbedded sands in the McMurray Formation could be indicative of a fluvial environment in which wide streams of low average velocity meandered across a gently sloping flood plain. The northerly direction of paleoslope indicated by the crossbedding of the McMurray Formation is very similar to that of the present land surface. The concept of a northward paleoslope indicates that a marine invasion occurred in Early Cretaceous time from the north. Logically, therefore, the sediments of the McMurray Formation are believed to have been derived from the Precambrian Shield to the southeast of the outcrop area and to have been deposited by a drainage system analogous to the Clearwater-Athabaska system that now drains the Shield area in Saskatchewan and Alberta. Author's text condensed.

Carrigy, M. A., 1967, The physical and chemical nature of a typical tar sand. Bulk properties and behavior: World Petroleum Congress, Proc., 7th, v. 3, p. 573-604.

The results of in-situ strength tests and confined compressive-strength tests on undisturbed samples show that the Athabaska tar sands behave as soft sandstones and that the conventional concepts of effective stress used in soil mechanics are applicable. Remolded tar sands have lower strengths than the in-situ material and, when compacted, their behavior is closely similar to that of manufactured bituminous-aggregate mixtures of the same composition. Author's conclusions modified. 
Carrigy, M. A., and Zamora, W. J., 1960, The Athabaska oil sands, in Oil fields of Alberta: Alberta Soc. Petroleum Geologists, Calgary, Canada, p. 38-49.

Three basic geological problems pertaining to the oil sands remain unsolved: (1) Determining accurately the geological extent of the oil sands; (2) identifying the stratigraphic limits of the oil impregnation; and (3) accurately estimating the amount of oil that they hold. Enough wildcat wells have been drilled to permit outlining the approximate limits of the oil sands in the basal Cretaceous. The oil impregnation, extending from T. 103 to possibly as far south as T. 69 and from R. 5 to R. 25, covers an area 204 miles long and 120 miles wide, or approximately 20,700 square miles. According to Carrigy (1959b) the Athabaska oil sands occupy a large structural stratigraphic trap. Much more drilling must be done before an accurate evaluation of the oil reserves of the oil sands can be made. The present estimate is 300 billion barrels.

Clark, K. A., 1944, Hot-water separation of Alberta bituminous sand: Canadian Inst. Mining and Metallurgy Trans., v. 27, p. 257-274.

There is little difficulty in recovering more than 90 percent of the oil from bituminous sand in a hot-water separation plant, especially if no importance is attached to the cleanliness of the recovered oil. It is more difficult to get high recovery of oil whose mineral-matter content is low. Two main processes are essential for clean separation of oil from bituminous sand: First, the oil should be displaced from the sand grains, using a minimum of water. Second, the oil, after displacement from the sand surfaces, should be changed into oil-froth form, using a minimum of air. Practical application of these processes requires that the bituminous sand be prepared for separation by heating and mixing with about 10-20 percent water. A pulp containing 10 percent water has enough air for the separation process; however, a pulp containing 20 percent water has no air, and the right amount of air must be supplied as it is submerged and dispersed in hot water. The separation plants erected and operated so far have been satisfactory from the standpoint of oil recovery, but they have failed to produce recovered oil having a low sand content. Author's conclusions condensed.

Clark, K. A., 1950, The hot-water-washing method for the recovery of oil from Alberta tar sands: Canadian Oil and Gas Indus., v. 3, p. 46-49.

The bituminous sands of Alberta are particularly amenable to treatment by hot water. A batch of bituminous sand is placed in the steam-jacketed mixer along with sufficient water to give the pulp a water content of about 12 percent. Mixing is continued for 15 minutes, and the temperature is raised to $185^{\circ} \mathrm{F}$. The final pulp is the consistency of thin brick mortar; it will pour, but contains no excess water. This pulp is dumped into the feeder, which passes it into the stream of hot water circulating through the rest of the apparatus. It is promptly dispersed into sand and oil flecks that are small but of various sizes. All but the very small oil flecks become associated with water vapor or air and form oil bubbles. The sand and oil bubbles are swept into the separation cell, where, under comparatively quiet conditions, the sand sinks, and the oil floats to the surface as a froth. The formation of the oil froth is essential for the primary recovery of the oil; however, because oil bubbles float mineral matter, an excess of frothiness can actually be 
detrimental by loading the froth with sand particles. Most of the very small oil flecks can be recovered by a subsequent operation consisting of passing the suspension of clay and fine oil flecks (free of sand) through a flotation cell. The importance of secondary oil recovery increases as the clay content of the bituminous sand increases. Author's text condensed.

Clark, K. A., 1957, Bulk densities, porosities, and liquid saturations of goodgrade Athabaska oil sands: Research Council Alberta Circ. 22, 22 p.

It was found to be useful to divide the material making up the McMurray oil sand formation into three catagories: Good-grade oil sand, containing 10 percent or more by weight of oil; shale, containing 4 percent or less of oil; and interbedded oil sand and shale, containing from 4 to 10 percent of oil. The present study is concerned only with the good-grade oil sand. The direct method for determining the porosity and the percent saturation with oil and with water is to measure the volume and the weight with a suitable sample of oil sand, and then to determine its contents of water, oil, and mineral matter. An indirect method of determining porosity is to use the sieve analysis of the mineral aggregate of the sample. This method is not accurate, but it can be made precise enough to test whether the directly determined porosity is reasonably accurate. Author's text condensed.

Clark, K. A., 1960, Permeabilities of the Athabaska oil sands: Canadian Mining and Metall. Bull., v. 53, p. 239-244.

The repacked mineral aggregates of good-grade oil sands have permeabilities ranging from 15 darcys to 350 millidarcys. The variation is due to the silt content of the aggregates. Few good-grade oil sands contain as much as 30 percent silt, most contain less than 20 percent, and a large proportion contain less than 10 percent. The permeabilities of repacked good-grade oil sands (oil included) depend on the degree of liquid saturation. When saturation with oil plus water reaches $80-90$ percent, permeability is reduced to zero. As saturation decreases below 80 percent, permeability increases rapidly. Permeabilities of 1-2 darcys were observed for total saturation of 60-70 percent. The mean value of 18 measurements of the permeabilities of "undisturbed" core samples of good-grade oil sands was 50 millidarcys. This value is probably too high. The mean value of 20 measurements in core samples of interbedded oil sand and shale was 100 millidarcys. The mean value for 11 measurements on shale was 10 millidarcys. Author's abstract modified.

Clark, K. A., and Alexander, E. L., 1951, Some laboratory results related to mining oil sand by block caving: Athabaska Oil Sands Conf., Proc., Edmonton, Canada, p. 158-161.

Mining ore by the block method involves undercutting the ore over a sufficient area to cause the unsupported column to fragment and fall away. Oil sand should be amenable to block caving. The material is unconsolidated sand held together by a liquid. In its natural state of packing, and with the oil at the formation temperature of $36^{\circ} \mathrm{F}$, the oil sand is more stable than one might suspect. However, it has no inherent strength, and if support is removed from below, it should spall and fall away. A laboratory experiment was made using a box 16 inches square inside and 5 feet high. It was tamped full of oil sand. The density of packing was 109 pounds per cubic foot as compared with about 120 pounds for undisturbed oil sand. The temperature was about $70^{\circ} \mathrm{F}$. The bottom of the box had a central section 12 inches square 
that was removed when packing was complete. Oil sand fell out of this opening until an arch formed. Then nothing more fell away. When the oil-sand column was undercut to the sides of the box, caving took place, and the box gradually emptied itself. There was no slipping of the oil-sand column along the sides of the box. Authors' text condensed.

Clark, K. A., and Blair, S. M., 1925, The bituminous sands of northern Alberta: Research Council Alberta Rept. 12, p. 46-65.

In general, the bituminous sand formation consists of two main economic divisions - a lower and an upper. The lower division immediately overlies the Devonian limestone. At some places it has a thickness of 100 feet. It has a much higher average bitumen content than the upper division and, in general, has a decided cliff-forming tendency. In comparison with the upper division, it has few lenses of clay or lean bituminous sand. The upper division consists of bands of lean, rich bituminous material overlying the lower division. The upper division contains all the bituminous sandstone, in contradistinction to the bituminous sand. This sandstone is hard and compact, is partially saturated with bitumen, and occurs near the top of the bituminous sandstone. A few very thin partings of brown lignite coal occur in the upper division. There is little change in the nature of the bitumen throughout both divisions. It is always a heavy dark-brown viscous oil and, with few exceptions, has a specific gravity between 1.010 and 1.035 . The sulfur content of the bitumen is consistently high and ranges from 4.5 to 5 percent. Water moving through breaks in the bituminous sands caused by recent slides bring some bitumen to the surface. The heat of the sun on the surface of a rich bituminous sand will cause a small quantity of bitumen to collect on the face of the outcrop, giving rise to surface enrichment.

Clark, K. A., and Blair, S. M., 1927, The bituminous sands of Alberta: Research Council Alberta Rept. 18, 74 p.

The bituminous sand formation is composed of a haphazard assortment of lenses of various material. There is a tendency for the upper beds to be changeable in nature and composed mostly of lean material, and for the thick, massive rich bituminous sand beds to occur toward the bottom of the formation. Generally, at least half the thickness of beds is of poor-grade material, and most of the good-grade material occurs near the bottom. The upper beds virtually constitute an overburden. One broad feature of lateral variability should be noted: the bitumen from the southern part of the area is heavier than the rest. It contains a smaller proportion of the lower boiling point oily constituents and yields a harder asphalt residue. The bitumen in the central and northern parts of the area is considerably lighter, contains more oil constituents, and forms a softer asphalt residue. A zone of exceptionally light soft bitumen occurs in the vicinity of the Ells River. Authors' conclusions condensed.

Clark, K. A., and Pasternack, D. S., 1932, Hot-water separation of bitumen from Alberta bituminous sands: Indus. and Eng. Chemistry, v. 24, no. 12, p. 1410-1416.

A procedure is described for determining yield of bitumen in laboratoryscale hot-water separation of bituminous sand. The procedure has been used for examining the effects of acidity or alkalinity and the presence of various 
salts, hydroxides, and clays in bituminous sand on the efficiency of separation. It was found that acidity in the bituminous sand must be neutralized in a preliminary treatment before washing with hot water is effective. Calcium and magnesium hydroxides were found to be particularly detrimental. Clay affected separation adversely and, commercially, is indicated as the most troublesome impurity in bituminous sand. Authors' abstract modified.

Conybeare, C. E. B., 1966, Origin of Athabaska oil sands - a review: Bull. Canadian Petroleum Geology, v. 14, no. 1, p. 145-163.

Sands of the McMurray Formation were derived mainly from Precambrian terrain to the east. Some material was derived from the igneous-metamorphic shield, but much was probably derived indirectly by erosion of the sandstones of the Athabaska Formation. In the Fort McMurray area, the lower beds of the McMurray Formation were deposited in various fluviatile environments; the upper beds represent a flood plain developed on a widespread delta. The upper, predominantly horizontally bedded strata of the McMurray Formation are of late Barremian or Aptian age; the lower, predominantly crossbedded and massive strata are of Valanginian age. Erosion of Devonian carbonates - especially the Grosmont reef complex - before and during deposition of the McMurray Formation may have released large quantities of oil. Oilsaturated detritus and alluvial sands may have been reworked, and part of the oil may have been transported and deposited with the McMurray sediments. After the deposition of the McMurray sediments, local migration of original transported oil may have occurred. Subsequent introduction of great quantities of oil, probably largely from Cretaceous sources but possibly also from Devonian sources, continued for an unknown period of time. Author's conclusions condensed.

Corbett, C. S., 1955, In-situ origin of McMurray oil of northeastern Alberta and its relevance to general problem of origin of oil: Am. Assoc. Petroleum Geologists Bull., v. 39, no. 8, p. 1601-1649.

The enormous size of the McMurray oil accumulation has made it necessary to postulate extraordinary conditions to account for its origin. Geologic opinion is divided between deposition in situ and derivation from Paleozoic rocks below and basinward. Humic acids derived from land plants were probably the major source material of the McMurray oil. Supporting this idea are the following factors: (1) The nature and quantity of the organic matter in sediments rich in such material, (2) the abundance of humic acid in the runoff waters of well-vegetated areas and the adequacy thereof to account for the oil which has been formed from post-Early Devonian source material, (3) the broad coincidence in the geologic time periods between the major oil resources and the coal resources of the earth, and (4) the environmental conditions and other factors relating to the deposition of the McMurray formation. Probable steps in the transformation to oil of the organic matter entering the sea in the river waters, with special reference to the McMurray deposit, have been (1) the formation of an asphalt-like substance, perhaps essentially contemporaneous with the precipitation of the organic matter by sea water, similar to certain occurrences of asphaltlike material in sands of Recent age in which waters from fresh-water swamps mingled with sea water, and (2) the solution in this asphaltlike material of bituminous plant substances (spores, pollen, resin, etc.) in the deposit. Depth of burial of the 
McMurray deposit has been insufficient to result in enough pressure or rise in temperature to complete the transformation to a typical crude oil, but the supersaturation of the sand with organic material probably had an appreciable effect in that direction. Author's abstract condensed.

Cottrell, J. H., 1963, Development of an anhydrous process for oil-sand extraction in Athabaska oil sands: Research Council Alberta Inf. Ser. 45, p. 193-206.

This process is essentially a countercurrent solvent-extraction scheme. The physical makeup of the sands consists of individual grains of sand surrounded by a thin film of water. The water is further encased by bitumen, and the bitumen partially fills the voids between the individual grains. The problem of separation, therefore, is that of dispersing the solid-water particles and extracting with solvents the enveloping bitumen films in a water-immisciblesolvent phase. The resultant solvent-bitumen mixture can then be drained from the solid-water particles and the drained bed subjected to repeated solvent washes to displace the bitumen mixture. Author's text condensed.

Davis, C. M., 1951, Electrovolatilization of oil in situ: Athabaska Oil Sands Conf., Proc., Edmonton, Canada, p. 141-152.

Electrovolatilization may be defined as the vaporization of a material by the electrical application of heat. The material is forced to become an electrical conductor, and the passage of current through it raises its temperature. Generally, organic substances offer high resistance to the passage of electrical current, but as the impressed voltage is increased, a point is reached at which the resistance is broken down and the organic material becomes a good conductor. It is customary to first heat the material electrically and then complete the heating by a more economical means. For example, a partial combustion of the material, using compressed air, may be used.

Djingheuzian, L. E., 1951, Cold-water method of separation of bitumen from Alberta bituminous sand: Athabaska Oil Sands Conf., Proc., Edmonton, Canada, p. 185-199.

A flowsheet with standard ore-dressing equipment was developed which obtained a net recovery of 95 percent of bitumen from the Horse River sand. The use of soda ash is imperative. When its use was discontinued, the result was always a low recovery of oil, even when the $\mathrm{pH}$ was over 9 . The optimum range of temperature was found to be $73^{\circ}-81^{\circ} \mathrm{F}$ though good recoveries were also obtained at as low a temperature as $70^{\circ} \mathrm{F}$ and as high as $83^{\circ} \mathrm{F}$. The optimum $\mathrm{pH}$ required appeared to be just over 9 . The mineral matter in the bituminous sand had to be reduced in the pebble mill from 5-7 percent minus200 mesh to 11-15 percent minus-200 mesh. Increases in clay content adversely affected thickness recoveries. Inasmuch as the best separation of oil in the classifier took place with a certain content of clay in the mill feed, there appears to be an optimum content which will assist in effecting the highest overall recoveries. Crude oil of a grade suitable for refinery treatment was produced consistently in a continuous process. Author's summary condensed.

Dor, A. A., Daly, W. J., Floyd, P. H., and Hall, F. T., 1967, Technical problems in the processing of mined sand for oil recovery: World Petroleum Congress, Proc., 7th, v. 3, p. 615-623. 
Comprehensive testing in a field-test unit of various surface, shaft, and bucket drill-core samples has resulted in modifications that were incorporated in the basic Clark hot-water process to adapt it to the wide variety of tarsand types that will have to be treated. This has been accomplished principally by using a two-stage flow sheet, including a separation cell, in which a primary oil froth is extracted, and a middlings flotation circuit, in which a secondary oil froth is recovered from the inner fraction of sands minerals. The bitumen froth so obtained is a mixture of water, solids, and oil which can be demineralized and dehydrated in conventional centrifuges after dilution with coker naphtha. Authors' conclusions.

Doscher, T. M., 1967, Technical problems in in-situ methods for recovery of bitumen from tar sands: World Petroleum Congress, Proc., 7th, v. 3, p. $625-632$.

The fundamentals of a number of possible production-enhancement methods are summarized in this paper, along with the limitations and problems associated with the methods. The techniques discussed include hydraulic or explosive fracturing, solution and emulsification processes, in-situ combustion, steam injection, oxidation and hydrogenation processes, nuclear detonation, and combinations of some of these processes. It is concluded that because of the physical nature of the Athabaska tar sand, the nature of the viscous crude contained therein, and the regional geological setting, possibly the only in-situ recovery process with commercial feasibility at this time is the one developed by Shell Canada, Ltd.: Selective hydraulic fracturing, or finding such naturally occurring communication that might exist, followed by the injection of emulsifying chemicals and steam. Author's text condensed.

Doscher, T. M., Labelle, R. W., Sawatsky, L. H., and Zwicky, R. W., 1963, Steam drive - a process for in-situ recovery of oil from the Athabaska oil sands, in Athabaska oil sands: Research Council Alberta Inf. Ser. 45, p. 123-141.

The Athabaska oil is so viscous that primary and secondary recovery methods common to the petroleum industry are not useful for producing the bitumen. To produce the oil without moving the sand, it is necessary to make the oil flow. The steam- and chemical-drive method of Shell Canada, Ltd., accomplishes this. The process requires that injection and production wells be drilled in regular patterns, such as a five-spot pattern. The wells are opened to the oil-sand formation, and a horizontal disklike fracture is propagated to connect the sets of injectors to the producers. Steam and aqueous alkaline solutions are then injected into the fracture. The oil adjacent to the fracture is heated and is then emulsified and driven to the producer as an oil-in-water emulsion. Authors' text condensed.

Ellison, A. H., 1959, Evidence of supersaturated zones in the Athabaska oil sands: Jour. Alberta Soc. Petroleum Geologists, v. 7, no. 8, p. 177-178.

The term supersaturated applied to the Lower Cretaceous McMurray oil sands appears to be justified. Theoretical maximum porosity of a well-sorted sand is about 35 percent; nonetheless, analysis of some cores taken from the Athabaska sand has shown porosity of more than 80 percent in pockets of oil containing scattered sand grains. Although the high value of 35 percent is frequently approached, the 80-percent-porosity pockets are relatively scarce and any sand grains in them are suspended in the oil. At room temperature 
the sand-free oil flows comparably to a $4^{\circ}$ API grade oil, but at the cool subsurface temperature of $36^{\circ} \mathrm{F}$ the viscosity increases to a puttylike quality. In the 200 holes drilled in a 13-square-mile area, none of the Beaverhill Lake limestone exudes oil or is even stained, although tarry, fossiliferous limestone boulders are common in the surface drift. These facts, together with the high viscosity of the oil and the interbedded nature of the sands and clays, suggest that transportation, rather than migration, was responsible for the oil in the McMurray sand. However, this does not preclude the slow migration of small quantities of viscous fluid from rich sands into zones of relatively low pressure, such as tension fissures, which may form over irregular microtopography. Author's text condensed.

Ells, S. C., 1914, Preliminary report on the bituminous sands of northern Alberta: Canada Dept. Mines, Mines Branch Rept. Inv. 281, 92 p.

Geologically, the bituminous sands represent the Cretaceous Dakota sandstones and directly, but unconformably, overlie Devonian limestones. These sands originally were soft sandstones and uncompacted sands; subsequent and fairly complete impregnation by heavy asphaltic hydrocarbons has resulted in the present coherent material. Overlying the bituminous sands are various soft Cretaceous sediments. The residual bitumen is assumed to have been derived from an asphaltic petroleum that possibly originated in underlying Devonian strata. Inflow has probably been horizontal, rather than an upwelling at many points over a large area. The Devonian strata were probably folded prior to oil impregnation of the Dakota sands.

Ells, S. C., 1924, Bituminous sands of northern Alberta, in Investigations of mineral resources and the mining industry, 1923: Canada Dept. Mines, Mines Branch Rept. Inv. 616, p. 4-12.

The area underlain by bituminous sands cannot be estimated at this time. The author examined about 270 individual outcrops, all of which are parts of a nearly continuous deposit. These outcrops extend along the Athabaska River and its principal tributaries, for a total distance of more than 200 miles. The northernmost exposure of apparent commercial value on the Athabaska River occurs in sec. 16, T. 98, R. 10. Other exposures of bituminous sand occur in Alberta on the Wabiskaw River, on the headwaters of Reid Creek, on the Muskeg River, on Buckton Creek, and on the Firebag River, and in Saskatchewan at Buffalo Lake. The occurrence of tar springs or seepages of bitumen has been recognized throughout the area. The author is familiar with about 40 such springs. Although none of them are of commercial value as a source of bitumen, they have been regarded as definite indications of the presence of petroleum pools. Instead of coming from below, however, the bitumen merely seeps laterally from slightly inclined beds of particularly rich coarse-grained sand. Author's text condensed.

Ells, S. C., 1962, Recollections of the development of the Athabaska oil sands: Canada Dept. Energy, Mines and Resources Mines Branch Inf. Circ. IC-139, $114 \mathrm{p}$.

This report is a history of the development of the McMurray district since the initial surveys and exploration.

Falconer, W. L., 1951, Stratigraphy of the McMurray Formation: Athabaska Oil Sands Conference, Proc., Edmonton, Canada, p. 26-29. 
The formation containing the Athabaska oil sands is known as the McMurray. It is the basal part of the Lower Cretaceous in northeast Alberta. Its main lithologic characteristics are a highly quartzose nature, massive oil impregnation, and the ever-present coarse crossbedding. The formation is oil saturated in the immediate area of the settlement of Fort McMurray and can be observed in river cuts for 138 miles along the Athabaska River and for 40 miles along the Clearwater River. The impregnation is spotty, however, and appears to be controlled by the grain size of the sand and its porosity, which, in turn, depends on its argillaceous content and the extent of cementation. Normal upward and lateral migration of low-grade residues from truncated pools of Devonian age are the most plausible explanations for impregnation of the sands. Author's text condensed.

Fortier, Y. O., McNair, A. H., and Thorsteinsson, R., 1954, Geology and petroleum possibilities in Canadian Arctic Islands: Am. Assoc. Petroleum Geologists Bull., v. 38, no. 10, p. 2075-2109.

Surface indications of petroleum consist of abundant rocks having a petroliferous odor and asphaltic residues. Active oil and gas seeps have not been found. On Cornwallis Island, asphaltic residues in a basal conglomerate indicate an exhumed reservoir. Marine and fresh-water oil shales and lowrank coals have been identified in several widely scattered areas. Authors' abstract condensed.

Gallup, W. B., 1960, Current exploratory techniques in the Athabaska bituminous sands area [Alberta]: Canadian Mining and Metallurgy Bull., v. 53 , no. 576 , p. $245-249$.

Current exploratory techniques involve a moderate amount of coring. Electrologs and, commonly, radioactive logs are run on most holes, and certain types of these achieved excellent qualitative analysis when backed up by some core analysis for calibration. Exploration is moving farther from the river, and a permanent network of access roads have been built during the last few years. Most exploration is done during winter. Some exploratory techniques are set up to go into recovery experiments where rich tar beds are found. There probably will be several methods of extraction, both mining and various in-situ techniques will be applicable, depending upon the condition. Author's abstract condensed.

Gibbon, Anthony, 1957, Is this the answer to the Athabaska oil sands riddle ?: World Oil, v. 145, no. 7 , p. 171-177.

Laboratory experiments carried out at the University of Texas on scale models of the Athabaska tar sand proved the feasibility of extracting tar by in-place operations. A steam-injection well pattern surrounds a producing well, from which the melted tar is recovered by flowing and (or) by pumping. The laboratory study showed the impossibility of recovering Athabaska tar by a single-well injection operation. Steam extraction of the tar must resort to steam injection from well to well in order to achieve proper steam condensation and heat transfer to the tar, thereby melting it sufficiently to drain and flow to a producing well. The experiment showed that about 50 percent of the tar in place may be recovered and at a steam ratio that would not exceed 5 barrels of vaporized water to 1 barrel of tar. Author's text condensed. 
Gold, Otto, 1967, Technical problems in the mining of tar sands: World Petroleum Congress, Proc., 7th, v. 3, p. 605-614.

Factors which affect the selection of equipment, mine layout, and sequence of operations are discussed as they relate to the open-pit mining of the sands. These factors include the overburden-to-sand ratio, geological and hydrological conditions, and general limitations of open-pit methods. Overburden removal is discussed from the standpoint of overburden properties, equipment selection, and field operations. Tar-sand mining is reviewed with respect to alternate methods, selection of ore, rejection of low-grade material, the conveying of tar sand and disposal of tailings. Author's abstract.

Goodspeed, F. E., and Montgomery, D. S., 1962, The determination of methyl and methylene groups in the oil and resin fractions of Athabaska bitumen using infrared spectroscopy: Canada Dept. Energy, Mines and Resources Mines Br. Research Rept. R98, 25 p.

A method of determining the methyl and methylene carbon present in the oil and resin fractions from the Athabaska bitumen, using infrared absorption spectra, is discussed. Absorption bands in the 3- and 7-micron regions are used, and data on pure compounds serve as a basis for quantitative estimates of these groups. Estimates obtained for the oil fractions were supported by the agreement of the total hydrogen content of the fractions that was obtained from the ultimate analysis with the hydrogen content predicted by this method. Authors' abstract.

Government of Alberta, 1951, Guide to the Alberta oil-sand area along the Athabaska River between McMurray and Bitumount: Board of Trustees, Oil Sands Project, Edmonton, Alberta, p. 1-18.

The bituminous sand deposit, in the area of outcrops along the Athabaska River, has a thickness of about 200 feet. It occurs in the Lower Cretaceous McMurray formation. It is composed of beds of unconsolidated sand, silt, and clay impregnated to various degrees with a viscous asphaltic oil. Bituminous sand, as mined with less than 20 percent fine material, generally contains 10-17 percent oil by weight and 2-8 percent water. The specific gravity of the bitumen at $25^{\circ} / 25^{\circ} \mathrm{C}$ ranges from 1.002 to 1.027 . Author's text condensed.

Gussow, W. C., 1941, Northern Alberta oil sands, in Possible future oil provinces in Western Canada: Am. Assoc. Petroleum Geologists Bull., v. 25, no. 8 , p. $1447-1456$.

The oil sands of northern Alberta occur in the McMurray formation, correlated as basal Lower Cretaceous. They lie without angular unconformity on a floor of base-leveled Devonian. They are of continental origin and appear to be a great delta swept off the Precambrian shield into the margins of an Early Cretaceous sea. The oil is a heavy, viscous, tarry crude. Formed and remaining in rocks that have little or no dynamic activity - and thus having escaped the pressures and heat to which oils in folded rocks have been subjected - it is obviously a virgin oil that has been converted only slightly beyond the asphalt stage. When subjected to moderate heat for a reasonable period, the whole oil changes from $10^{\circ}$ API to $20^{\circ}-22^{\circ}$ API without forming free carbon. The oil is not a pore-space filling in the sand, but a film enveloping each sand grain. It is the sole cementing material of the sand; its removal leaves the sand as free as that on a beach. To recover the oil the sand must 
be mined and the oil distilled, dissolved out, or washed out with hot water. The hot-water method is the most practicable and economical, and is the one now in use commercially. More than 99 percent of the deposit is too deeply buried for mining under present-day conditions. The only workable deposits are the benches along the valley walls of Athabaska River and some of its tributaries, where the streams have cut through the overlying beds and into or through the oil sands. The minable benches are estimated to contain $\mathbf{5 0 0}$ million to 1 billion barrels of oil. Author's text condensed.

Gussow, W. C., 1956, Athabaska bituminous sands, in Symposium Sobre Yacimientos de Petroleo y Gas, v. 3: International Geol. Congress, 20th, Mexico, p. 68-70.

The McMurray formation is characterized by crossbedding and considerable variation in grain size. It is composed of lenticular sands, silts, and clay and contains occasional tree trunks and lignitic beds. It varies considerably in thickness and has a maximum known thickness of 180-200 feet near McMurray. The Athabaska bituminous sands contain a heavy black, viscous, asphaltic crude having an API gravity of about $10^{\circ}$. Its sulfur content ranges up to 5 percent. Published estimates of reserves for these deposits range from 100 billion barrels of crude to 500 billion barrels. These sands are postulated to be a gigantic stratigraphic-trap accumulation. Author's text condensed.

Haliburton, James, 1947, Liquid diffusion in porous media, with specific reference to the Athabaska tar sands: British Columbia Univ. unpub. M.S. thesis, Vancouver, $19 \mathrm{p}$.

In chemical engineering, a large number of unit processes depend on the diffusion of material through fluid films. Some of these operations are drying, rectification, gas absorption, extraction, and crystallization. This paper discusses the theoretical basis of diffusion with special reference to diffusion through a porous body, and discusses experimental methods of solvent extraction of bitumen from the tar sands of the Athabaska deposits. According to the diffusion theory presented, the mechanism involved in the extraction of the tar sand by benzene is one of true molecular diffusion. The diffusion constant was found to be $D=2.39 \times 10^{-5} / \mathrm{ft}^{2} / \mathrm{hr}$. Author's text condensed.

Hardy, R. M., and Hemstock, R. A., 1963, Shearing strength characteristics of Athabaska oil sands, in Athabaska oil sands: Research Council Alberta Inf. Ser. 45 , p. 109-122.

Measurement of the shearing strength of cores showed that on release of stress, gas comes out of solution in the oil phase. Gas pressure in the pores increases with increasing temperature of the oil sand, and the oil phase, owing to its high viscosity, has the effect of delaying the dissipation of the gas pressure. Strength lost because of gas pressure is largely recovered if the gas pressure is dissipated. Under in-situ conditions, the oil sands tested had strength deformation characteristics consistent with those of a dense sandstone. Authors' abstract condensed.

Hitchon, Brian, 1963, Composition and movement of formation fluids in strata above and below the pre-Cretaceous unconformity in relation to the Athabaska oil sands, in Athabaska oil sands: Research Council Alberta Inf. Ser. 45 , p. 63-74. 
A high degree of correlation exists between the composition of formation fluids from strata above and below the pre-Cretaceous unconformity in Alberta. Potentiometric surface maps indicate that there is a free-fluid connection across the unconformity and that the formation-fluid movement close to the unconformity is northeastward and in the strata having the highest permeability. According to a study of the crude oil composition, the position of the lower Cretaceous oil sand deposits on the broad continental shelf, which covered nearly all of Alberta in Early Cretaceous time, is reflected in the asphaltic nature of the crude oils. These factors are consistent with a major Cretaceous source for the oil in the Athabaska oil sands, with a possible additional source in the pre-Cretaceous rocks. Author's abstract condensed.

Hitchon, Brian, Round, G. F., Charles, M. E., and Hodgson, G. W., 1961, Effect of regional variations of crude oil and reservoir characteristics on in-situ combustion and miscible-phase recovery of oil in Western Canada: Am. Assoc. Petroleum Geologists Bull., v. 45, no. 3, p. 281-314.

Of the more than 20 billion barrels (exclusive of the crude oil in the McMurray formation) of original in-place crude oil discovered in Western Canada to date, it is expected that about 4.75 billion barrels will be produced by primary methods and water flooding. Secondary recovery methods, such as in-situ combustion and miscible-phase flooding, could result in the production of an additional 8 billion barrels. Authors' abstract condensed.

Hitchon, Brian, and Shaw, D. R., 1960, Regional variations in the properties of formation fluids in Alberta, in Oil fields of Alberta: Alberta Soc. Petroleum Geologists, Calgary, Canada, p. 27-38.

The following broad generalizations may be made concerning the regional variations of the physical and chemical attributes of formation fluids in Alberta. The subcrop margins and Sweetgrass Arch region are characterized by crude oils with gravities generally heavier than $30^{\circ}$ API and by relatively methane-rich low-ethane-plus moderate nitrogen, and low or absent hydrogen sulfide and carbon dioxide containing natural gases. The associated formation waters commonly contain less than $35,000 \mathrm{mg} / 1$ total dissolved solids and in places less than $10,000 \mathrm{mg} / \mathrm{l}$ dissolved solids.

Hodgson, G. W., 1954, Vanadium, nickel, and iron trace metals in crude oils of Western Canada: Am. Assoc. Petroleum Geologists Bull., v. 38, no. 12, p. 2537-2554.

Typical crude oils from western Canada produced from host rocks ranging in age from Upper Devonian to Upper Cretaceous were examined for the occurrence of vanadium, nickel, and iron trace metals. The concentration of the metals, believed to have been closely associated with the oils since genesis, varied inversely with the API gravity of the oils. The concentration of the three metals in the oils varies from 0.04 to about 600 parts per million. In general, the vanadium-containing organic molecule appears to be less stable than the nickel-containing molecule, resulting in a net lowering of the vanadium-to-nickel ratio of the oils as the apparent age becomes older. In detail, some of the trace-metal results appear to add to knowledge about the time and mode of migration and accumulation of crude oils in Western Canada. Author's abstract condensed. 
Hodgson, G. W., and Baker, B. L., 1959, Geochemical aspects of petroleum migration in Pembina, Redwater, Jaffre, and Lloydminster oil fields of Alberta and Saskatchewan, Canada: Am. Assoc. Petroleum Geologists Bull., v. 43 , no. 2, p. 311-328.

The chemical character of the crude oils produced throughout four major fields and several minor fields in Western Canada was studied. The variations in nickel and vanadium content appear systematic and are undoubtedly a key to accumulation history of the oils. The metal variations run parallel to variations in sulfur, resins, and asphaltene content of the oil, as well as to the gravity, and are sensitive indicators of crude-oil alteration. In the Pembina field, the magnitude of the variations from point to point in the field is very large, about tenfold for the metals. Much smaller variations are noted for the other fields; this may be a result of the smaller size of these fields. If the data are interpreted in light of probable adsorption alteration during accumulation and probable source conditions, the Pembina-Cardium oil apparently accumulated in the Cardium sands in a direction away from the present updip edge at the northeast; the Redwater oil, from downdip toward the south; the Viking Jaffre oil, from downdip at the southwest; and the Lloydminster oil pool, from very local source rocks. Authors' text condensed.

Hodgson, G. W., Matchen, Ben, Peterson, W. S., and Gishler, P. E., 1952, Oil from Alberta bitumen - Simultaneous dehydration and coking, using fluidized solids: Indus. and Eng. Chemistry, v. 44, p. 1492-1496.

Two general methods of recovering oil from the mined sand are well known. One is a direct distillation of oil from the sand in a fluidized bed to produce a clean dry coker distillate in a single operation. The other method makes use of water, either hot or cold, as a partition agent for separating the oil from the sand in a flotation step. The water-separation processes reject the bulk of the sand and produce an unaltered crude oil containing a considerable amount of emulsified water. Hot-water separation yields a product of 64 percent oil, 32 percent water, and 4 percent solids. This paper describes a variation of the flotation method, whereby removal of water and solids from the crude oil produces a suitable crude feedstock for a refinery. It involves feeding the wet crude oil produced by water separation directly to a fluidized sand bed maintained at about $500^{\circ} \mathrm{C}$. Simultaneous dehydration and coking yield a clean dry oil, the properties of which differ markedly from those of the oil in the charging stock. Authors' text condensed.

Hodgson, G. W., Peake, Eric, and Baker, B. L., 1963, The origin of petroleum porphyrins: The position of the Athabaska oil sands, in Athabaska oil sands: Research Council Alberta Inf. Ser. 45, p. 75-100.

The Athabaska oil sands contain a crude oil similar in metal-porphyrin content to other high-sulfur oils. It has a predominance of vanadyl-porphyrin pigments over nickel pigments, and though the bulk of the porphyrin material is decarboxylated, a small quantity exists as free acids, and some as organic esters. These pigments were examined and compared with those in conventional crude oils, other oil sands, and related source environments. Conventional crude oil shows a trend toward dominance of the nickel porphyrins with increasing API gravity and decreasing sulfur. Examination of the pigments in ancient sediments show the presence of porphyrin pigments, and recent sediments show the presence of chlorin pigments in addition to por- 
phyrins. The younger the sediments, the more dominant the chlorin pigments. Nickel complexes of porphyrins were found in open-sea marine sediments, but were overshadowed by vanadyl porphyrins in sediments in a restricted marine bay. Metal chlorins are common in recent sediments, in ground water, and in plants. Coal, peat, and oxidized marine shales showed extensive degradation of pigment. Precambrian rocks are evidently devoid of porphyrin pigments. The Athabaska oil is apparently typical of a source region of restricted circulation that is marked by high rates of deposition and strong reducing potentials. Authors' abstract condensed.

Hopper, D. A., 1945, Liquid diffusion in porous media, referring in particular to the Athabaska tar sands: British Columbia Univ. unpub. M.S. thesis, Vancouver, $18 \mathrm{p}$.

The mechanism of diffusion in porous solids has been applied to the Athabaska tar sands. At present, the tar sands are being worked on a limited scale. Following open-pit mining of the tar sand, the asphalt is separated from the sand by agitation with hot water and then cracked to produce gasoline and lowered-viscosity residual fuel or asphalt. An alternative recovery method might be the solvent extraction of the sands in situ, lifting the asphalt solution to the surface by a conventional oil-field water drive. Such a method might find application in selected regions of the field where the underlying formations would minimize solvent losses. Judging from this experiment, extraction of Athabaska tar sand in carbon tetrachloride probably proceeds by molecular diffusion. Author's text condensed.

Hoskins, A. D., 1964, How hydrogen will be used to upgrade Athabaska tar to sweet crude oil: Oil and Gas Jour., v. 62, no. 20, p. 122-124.

Shell Canada, Ltd., proposes to upgrade 130,000 barrels per day of Athabaska tar to 100,000 barrels per day of $33^{\circ}$ API sweet crude oil. The tar will be extracted in situ from the tar sands and will arrive at the processing plant emulsified with 70 percent water. There, the tar will be dehydrated and fed to a thermal-cracking unit, the first step in the upgrading process. The heavy residual oil will be removed for fuel, and the total liquid distillate accumulated in a naphtha and light gas-oil fraction and a heavy gas-oil fraction. Following severe hydrotreating in two separate trickle-phase hydrotreaters to remove sulfur, nitrogen, etc., the fractions are combined to form $33^{\circ}$ API sweet crude oil. Author's abstract condensed.

Hume, G. S., 1933, Oil and gas in Western Canada, Chapter 7: Canada Geol. Survey Econ. Geology Rept. 5, p. 229-254.

The McMurray formation (Lower Cretaceous), composed of massive and crossbedded sandstones, is considerably impregnated with bitumen. The bitumen content varies from place to place and even in different layers of the same exposure. The richest parts contain more than 20 percent bitumen, but the average bitumen content is considerably less. The McMurray is at least partly a deltaic deposit. The contact of the Devonian limestone with the overlying McMurray formation is an erosion surface, and many of the cracks and joints in the limestone are filled with bitumen. This has been interpreted as indicating that the bitumen came from below, but it seems more reasonable to assume that the cracks and joints were filled by seepage from above. The limestone as a whole is dense, white, and free from bitumen. It is difficult 
to understand how such a great migration of oil could occur unless it was along fissures. Because indications of oil occur in Lower Cretaceous strata in Wainwright and other areas, the author assumes that the bitumen in the bituminous sands originated in the Lower Cretaceous strata, part of which is McMurray strata, and that any bitumen now filling cracks and joints in the upper part of the Devonian limestones has resulted from downward (or gravitational) seepage. The Lower Cretaceous strata must therefore have been capable of forming a very large amount of petroleum, and the bituminous sands are the residue left after evaporation of the lighter oil constituents at the outcrop, where the oxidation of, and changes in, the oil have resulted from contact with sulfate waters, etc. Author's text condensed.

Hume, G. S., 1944, Athabaska bituminous sands, in Petroleum geology of Canada: Canada Geol. Survey Econ. Geology Rept. 14, p. 30-34.

In northern Alberta, 300 miles north of Edmonton, an area of bituminous sands in the Lower Cretaceous McMurray formation rests directly on Devonian limestones. The center of the area is at Fort McMurray on the Athabaska River, but the sands crop out along the river for 42 miles north of Fort McMurray and for 76 miles south of it and on tributary streams. The McMurray formation has a thickness of 110 to 180 feet, and as shown by large-scale crossbedding, is deltaic. The oil in the Fort McMurray deposit may have been derived from the edge of the delta, and, if so, the distance of migration would have been small. Drilling exploration to find the grade of the bituminous sands in several localities seems to show that the deposits are richer close to the outcrops than they are at some distance from them. This, if true, partially invalidates the estimates of tremendous volumes of oil content in the bituminous sands. There is a suggestion, also, that the richer areas of bituminous sands occur in the synclines of the undulating surface. At the Abasand location the bitumen content is 15 percent, or 0.9 barrel per ton of bituminous sand. In some areas (but perhaps not all), the lower beds of the bituminous sands are known to be richer than the upper beds. These facts suggest some migration, but none of the evidence is conclusive. Author's text condensed.

Hume, G. S., 1947a, Results and significance of drilling operations in the Athabaska bituminous sands: Canadian Inst. Mining and Metallurgy Trans., v. 50, p. 298-324.

The bituminous sands in the Steepbank area, about 22 miles north of Fort McMurray was found, from previous investigations, to be reasonably rich in bitumen and to have relatively light overburden. The present study shows that the bituminous sands vary considerably both in richness and in the amount of interstratified clay. In the 520-acre area there is an estimated 167 million tons of bituminous sands having an average grade of 12.96 percent bitumen by weight. The Horse River area is not considered to be satisfactory for large-scale operations; however, drilling was done to determine the size and value of the deposit within a reasonable distance of the plant. Immediately adjoining the plant is an estimated 500,000 tons or more of bituminous sands containing an average of 15.5-16.3 percent bitumen by weight. Eighteen holes were drilled in the east Steepbank area, and two reasonably good deposits were outlined. The west deposit, investigated by 15 holes, was calculated to contain 38 million tons of bituminous sands having an average grade of $\mathbf{1 2 . 3}$ percent bitumen in 92 acres. The ratio of the thick- 
ness of bituminous sand to the thickness of overburden there was calculated as $1.8: 1$. The less well defined east deposit is inferred to contain 20 million tons of sands containing 13.5 percent bitumen in 43 acres. Its ratio of thickness of bituminous sands to the thickness of overburden is $1.5: 1$. Author's text condensed.

Hume, G. S., 1947b, Mildred-Ruth Lakes area, in Results and significance of drilling operations in the Athabaska bituminous sands: Canadian Inst. Mining and Metallurgy Trans., v. 50, p. 298-324 [p. 300-302].

This area is on the west bank of the Athabaska River opposite the mouth of Steepbank River, about 22 miles north of Fort McMurray. The bitumen beds in the McMurray formation are interstratified with the bituminous sands. It is hardly conceivable that the bitumen could have been forced in between the sands after they were deposited; therefore, the bitumen beds are believd to be part of the succession of deposition. The average bitumen content probably exceeds 15 percent. Author's text condensed.

Hume, G. S., 1951, Possible Lower Cretaceous origin of bitumen in bituminous sands of Alberta: Athabaska Oil Sands Conference, Proc., Edmonton, Canada, p. 66-75.

The evidence appears to favor contemporaneous deposition of the bitumen with the McMurray formation of Early Cretaceous age. The McMurray is apparently a deltaic or alluvial-plain or fan deposit. At least the late stages of deposition were associated with the presence of a sea with a strandline along which oil formation could occur. The presence of Early Cretaceous fields containing heavy oil in east-central Alberta, western Saskatchewan, and elsewhere suggests a common origin for all the bitumens of the bituminous sands, inasmuch as all occurrences are known to be associated with near-shore conditions giving alternation of marine beds interstratified with nonmarine sediments of Early Cretaceous age. Author's text condensed.

Huntley, L. G., 1916, Oil, gas, and water content of Dakota sand in Canada and [the] United States: Am. Inst. Mining Engineers Trans., v. 52, p. 329-352.

Where the Dakota sandstone (Cretaceous) crops out along the Athabaska River, from Crooked Rapids to Fort McKay, and in the tributary streams on either side, it is saturated with inspissated petroleum or "tar." This tarsaturated sand continues up the Clearwater River eastward and is also reported in the vicinity of Buffalo Lake, across the line in Saskatchewan. A large lake of this tar has also been reported between the Athabaska and Peace Rivers, and its tar probably exudes from the Dakota a few feet below the surface. A small amount of dry sulfurous "tar" also comes along with the gas from the old government well at Pelican Rapids. Author's text condensed.

Innes, E. D., 1967, Canada's first commercial tar-sand development: World Petroleum Congress, Proc., 7th, v. 3, p. 633-650.

The first commercial-scale effort to exploit the Athabaska tar sands is nearing completion and is expected to start operation in early summer of 1967. A geological evaluation was conducted to define the size and shape of the deposit and the variations in the important properties. A research and 
development program was conducted to determine the optimum process for separating bitumen from the sand. Commercially, the tar sand is mined by open-pit methods and conveyed to the extraction plant, where the bitumen is separated from the sand by means of hot-water separation. The bitumen is coked, and the coker distillates are hydrogen treated to produce - when recombined - a low-viscosity low-pour-point synthetic crude oil that is low in sulfur, nitrogen, and aromatics content. The plant is designed to produce 45,000 barrels of petroleum per calendar day of product. Author's abstract.

Kidd, F. A., 1951, Geology of the bituminous sand deposits of the McMurray area, Alberta: Athabaska Oil Sands Conf., Proc., Edmonton, Canada, p. $30-38$.

The McMurray is Lower Cretaceous, equivalent to the lower part of the Blairmore formation of the foothills. Throughout the McMurray district, the McMurray formation unconformably overlies rocks of known Devonian age. Except for its differences in bitumen content, the formation everywhere exhibits the same or similar variations in lithology, and, although no two exposures are the same, their variations are consistent in type. It has been generally accepted that the McMurray formation represents a deltaic deposit, whose sediment source was the Precambrian area to the north and east. The author suggests that, rather than being deltaic, the formation represents a broad flood plain or coastal lowland deposit and that an Early Cretaceous sea lay some distance to the west. Outcrops of the McMurray formation occur intermittently along the Athabaska River for approximately 100 river miles. Along the Clearwater River, main tributary to the Athabaska, the formation extends into Saskatchewan; however, it is not impregnated with bitumen north of T. 89, R. 5 W., 4th meridian. The area of McMurray formation impregnated by bitumen is almost 3,000 square miles, where the thinnest section known is more than 100 feet thick. If it were not for the binding and cementing effect of the heavy bitumen, the greater part of the McMurray formation would be practically nonindurated and unconsolidated. Author's text condensed.

Kinney, G. T., 1963, Black oil may challenge Athabaska: Oil and Gas Jour., v. 61 , no. 50 , p. $54-55$.

Heavy-crude oil reserves outside the Athabaska deposits cover 2,250,000 acres, from which recovery operations could yield an estimated 35 billion barrels of upgraded synthetic-crude oil. The Athabaska deposits cover some $5,750,000$ acres and contains 626 billion barrels of oil in place; of this, 369 billion barrels are recoverable. The other deposits have 85 billion barrels of oil in place, of which 47 billion barrels are recoverable. The Athabaska deposits consist of grains of sand imbedded in almost solid masses of hydrocarbons. The other deposits - especially those in the Peace River area - occur as hydrocarbons in a rock matrix. The three major deposits - Athabaska, Bluesky-Gething, and Grand Rapids - occupy some 8 million acres, or almost 5 percent of the entire province. Each deposit occurs in different units of the Lower Cretaceous rocks. Author's text condensed.

Kleinpell, R. M., 1932, Occurrence of bitumen in Queen Charlotte Islands, British Columbia: Am. Assoc. Petroleum Geologists Bull., v. 16, no. 8, p. 797-798. 
At Tian Head, on the west coast of Graham Island (about lat $53^{\circ} \mathbf{4 5}$ N., long $133^{\circ}$ W.), tar and thick black oil exude from a white crystalline calcite vein or lentil, 2-4 inches thick, in metamorphosed green siltstone and sandstone. These rocks dip gently northwest and underlie a horizontal thick sheet of late Tertiary columnar basalt. The bituminous calcite crops out as a vein a few yards long. Similar occurrences of bitumen occur in amygdules, 2-3 inches in diameter, in the metamorphic rocks and along fracture planes in the nearby basalt, from which the bitumen is separated by quartz and chalcedony bands. Author's text condensed.

Krieble, V. K., and Seyer, W. F., 1921, A chemical investigation of the asphalt in the tar sands of northern Alberta: Am. Chem. Soc. Jour., v. 43, pt. 1, p. 1337-1349.

The asphalt from the Alberta tar sands was analyzed by the Marcusson method and compared with the Trinidad and Bermudez asphalts. A laboratory method was devised to extract the hydrocarbon oil from the asphalts on a sufficiently large scale for fractional distillation. It is the only extraction method so far devised which produces oils identical to those in the original asphalt. The results show that heavy hydrocarbon oils can be distilled at temperatures up to at least $300^{\circ}$ without the aid of carbon dioxide, provided the temperature is kept low enough. Thirteen apparently pure hydrocarbons were isolated and their physical properties studied. They belong to the $\mathrm{C}_{n} \mathrm{H}_{2 n}, \mathrm{C}_{n} \mathrm{H}_{2 n-2}$, and $\mathrm{C}_{n} \mathrm{H}_{2 n-4}$ series. Authors' summary condensed.

Kupsch, W. O., 1954, Bituminous sands in till of Peter Pond Lake area, Saskatchewan: Saskatchewan Dept. Mineral Resources Rept. 12, 35 p.

The Peter Pond Lake area is in west-central Saskatchewan near Buffalo Narrows. The bituminous sands occur on both sides of "The Narrows" between what is locally called Big Buffalo Lake (or Beef Lake) and Little Buffalo Lake, together called Peter Pond Lake. The bituminous sands are exposed in trenches in the glacial drift on Willow Point and on Fleury Point. The sands are physically similar to samples collected from the bituminous facies of the McMurray formation in Alberta. These sands are blocks of "Athabaska tar sand" transported bodily by the glacier ice. The only source of the fragments of "Athabaska tar sand" is to the northwest; thus, ice movement from that direction has to be assumed. This is substantiated by the occurrence at Buffalo Narrows and Ile-à-la-Crosse of bituminous and nonbituminous dolomite erratics with Devonian fossils. The only possible source for these erratics is also north-northwest of Peter Pond Lake. The evidence presented by the "indicators" in the till of Peter Pond Lake apparently conflicts with that of the deposits on the Precambrian Shield. Ice movement from the northwest is assumed to have occurred at a different time during the Pleistocene from that of the ice movement from the northwest. Author's text condensed.

Larson, V. C., Peterson, R. B., and Lacey, J. W., 1967, Technology's role in Alberta's Golden Spike miscible project: World Petroleum Congress, Proc., 7th, v. 3, p. 533-544.

Technology has been an important factor in making possible the Golden Spike project, where a gravity-controlled gas-driven miscible bank is expected to recover 95 percent of the 320 million barrels of oil in place. Almost since 
discovery, the Golden Spike reservoir - a Devonian pinnacle reef of limited areal extent - has been known to be susceptible to miscible displacement. Field application of the Golden Spike project required both advanced technology and a satisfactory means of obtaining the vast quantities of solvent required. The miscible bank is generated by stripping light petroleum gas from the reservoir oil, which is cycled through the surface facilities and returned to the reservoir. Technology's part included studies to resolve bank placement, size, and composition and to overcome well plugging resulting from injecting the stripped crude. A two-dimensional analysis on a digital computer showed that the solvent, inserted between the gas cap and the oil column, would blanket the oil in a little more than 2 years. Plugging of the injection wells is avoided by heating the stripped crude. Authors' abstract modified.

Link, T. A., 1932, Oil seepages in Belt Series of Rocky Mountains near international boundary: Am. Assoc. Petroleum Geologists Bull., v. 16, no. 8, p. 786-796.

The oil seepages in the Precambrian rocks of the Lewis and Clarke Ranges may have originated in upper Paleozoic (Devonian or Carboniferous), Jurassic, or, in part, in Colorado (Late Cretaceous) shale source beds. Upper Paleozoic porous limestones or dolomites may be the reservoir rock or may have acted as "carrier beds." Migration from these beds to the surface may have occurred along major overthrust and underthrust faults or fractures within the Precambrian rocks. These faults and fractures seem to be the determining structural condition. Author's conclusions condensed.

Link, T. A., 1951, Source of oil in "tar sands" of Athabaska River, Alberta, Canada: Am. Assoc. Petroleum Geologists Bull., v. 35, no. 4, p. 854-864.

The Lower Cretaceous "tar sands" of the Athabaska, or "McMurray bituminous sands," in northeastern Alberta, Canada, are believed to have derived their bituminous content from the underlying Upper Devonian coral-reef reservoirs which came in contact and near contact with the overlying sands at the unconformity between Lower Cretaceous and the Devonian. The white quartz sands were supplied from the Precambrian "Athabaska sandstone" lying at the northeast on the Canadian Shield, and it was suggested that the escape of oil and gas through fissures and fractures from the Devonian reservoirs into the "tar sands" occurred primarily during, but also possibly after, the deposition of the Cretaceous "tar sands." The Lower Cretaceous heavy oil of Lloydminster, Alberta, is also believed to have had a similar history. Author's abstract modified.

Lowell, P. F., Reif, H. E., Burk, R. O., Hertel, P. H., and Abbott, B. T., 1966, Sun building plant designed to recover first commercial tar-sands crude: Oil and Gas Jour., v. 64, no. 33, p. 66-72.

The crude, produced by Great Canadian Oil Sands, Ltd., will be desulfurized light synthetic material obtained by processing the heavy bitumen contained in the tar sands. The unique properties of this feedstock make it especially useful in refining operations. The light sweet crude will have a low pour point, low sulfur content, and no bottoms. Studies show that maximum value will be realized from the synthetic material when it is processed in blend with conventional crudes. Authors' text condensed. 
McConnell, R. G., 1893, Report on a portion of the district of Athabaska, comprising the country between Peace River and Athabaska River, north of Lesser Slave Lake: Canada Geol. Survey Ann. Rept., v. 5, part 1, Rept. D, 1890-91, 62 p.

The tar sands must have originally consisted of almost unconsolidated sands and soft sandstone, ranging in texture from a fine silt to a coarse grit, but they have since been cemented into a tarry mass, 200 feet thick, by the heavy constituents of the oils that have welled up during the past, in almost inconceivable quantities, from the underlying Devonian limestones. Downstream along the Athabaska River, the tar sands thicken from 140 feet at Crooked Rapid to 200 feet at the forks. The tar sands hold in place lenticular beds of limestone, lignite seams 2-3 feet thick, and fragments of fossil wood. They vary in color according to the quantity of tar they contain, from a gray to dark brown to jet black. Where the sands are heavily saturated, streams of tar issue from the banks during the heat of summer and form pools at the bases of the escarpments. These sands have been assigned to the Dakota (Cretaceous) entirely on lithological and stratigraphic evidence. No fossils were obtained from them. They rest on Devonian limestones and occur in the same position as the sands of Dakota, which crop out along the east edge of the Cretaceous in Manitoba and to the south in Minnesota. Indications of oil are also found on the Peace River and at Lesser Slave Lake, where inspissated bitumen occurs in a number of places as lining of cracks in nodules. At Tar Island in the Peace River, small quantities of tar are brought to the surface by a spring. Author's text condensed.

Mellon, G. B., 1956, Heavy minerals of the McMurray formation, in Geology of the McMurray formation: Research Council Alberta Rept. 72, p. 30-43.

The McMurray formation consists of loosely consolidated quartzose sands held together by bitumen. The sands of the McMurray consist of 90-95 percent quartz and minor amounts of orthoclase, muscovite, and heavy minerals. The heavy-mineral assemblage of the McMurray formation can be divided into two groups: (1) First-cycle minerals, derived from an igneous-metamorphic terrane. This group includes all staurolite, kyanite, chloritoid, garnet and apatite, and approximately two-thirds of the tourmaline and zircon. The first four minerals are metamorphic, whereas the apatite, zircon, and most of the tourmaline indicate an igneous source. (2) Second-cycle minerals, derived from preexisting sedimentary rocks. This group includes about onethird of the tourmaline and zircon, and possibly some rutile. The sediments of the McMurray formation constitute a petrologic unit. The formation was emplaced as a submerging delta. Source of the sediment was to the east from a well-weathered area of low relief underlain by igneous, metamorphic, and sedimentary rocks - that is, the Canadian Shield. Author's text condensed.

Mellon, G. B., and Wall, J. H., 1956, Foraminifera of the upper McMurray and basal Clearwater formations, in Geology of the McMurray formation: Research Council Alberta Rept. 72, p. 1-29.

Fifteen species and subspecies of foraminifera, of which 12 are new, from the upper part of the McMurray formation and the basal part of the Clearwater formation in the lower Athabaska River area of northeastern Alberta are figured and described. These faunas are correlated with foraminiferal assemblages from the Cummings member of the Mannville formation of east- 
central Alberta and from the upper part of the Loon River formation of the Peace River area of northwestern Alberta. The suites are dated Middle Albian in age (late Early Cretaceous). Environment of deposition appears to have been brackish lagoonal and shallow marine. Author's abstract.

Montgomery, D. S., 1951, On the origin of the Athabaska oil: Athabaska Oil Sands Conf., Proc., Edmonton, Canada, p. 76-87.

In density, the Abasand bitumen differs markedly from a typical Devonian crude, whereas its density is remarkably similar to the Cretaceous crude oils of Canada. The molecular-weight distribution, as indicated by the distribution range and the specific gravity of the distilled $250^{\circ}-275^{\circ} \mathrm{C}$ cut, suggests very strongly that the Alberta bitumen belongs to the class of oils that formed during Cretaceous time. The conclusions drawn in this work refer strictly to the bitumen of the Abasand quarry. Caution should be exercised in extending these conclusions to the entire bituminous sand area, which is said to underlie 30,000 square miles. Author's text condensed.

Nagy, B., and Gagnon, G. C., 1961, Elution and spectroscopic analysis of the petroleum from the vicinity of McMurray, Alberta, in The geochemistry of the Athabaska petroleum deposit: Geochim. et Cosmochim. Acta, v. 23, p. 155-185.

The sandstone and shale beds of the McMurray formation are impregnated with a semisolid petroleum. The Athabaska deposit is the largest known petroleum deposit in the world. Sandstone samples from the bottom of the Abasand quarry, near McMurray, yielded 16.5 percent organic matter upon extraction with methylene chloride at room temperature. The extract contained approximately 22 percent asphaltenes and was abundant in residuum upon distillation to $350^{\circ} \mathrm{C}$ at atmospheric pressure. Mass spectrometric analyses of the $n$-heptane, benzene, and pyridine eluate fractions led to the identification of the following hydrocarbon constituents: Paraffins, naphthenes, alkylbenzenes, cycloalkyl benzenes, naphthalenes, and phenanthrenes. The following nonhydrocarbon components may also be present: Pyridines, carbazoles, benzothiophenes, and thiophenophenanthrenes. The organic material in the McMurray formation is a petroleum. Authors' summary condensed.

Natland, M. L., 1963, Project Oilsand, in Athabaska oil sands: Research Council Alberta Inf. Ser. 45, p. 143-155.

Project Oilsand is a proposed experiment in the peaceful use of nuclear energy as an aid in producing oil from the McMurray oil sands buried too deeply to permit economic extraction by mining methods. A 9-kiloton nuclear device would be detonated 20 feet below the McMurray oil sand, at a depth of 1,250 feet. The proposed test site is in a remote undeveloped area about 64 miles south of Fort McMurray. The contained explosion will create a cavity about 230 feet in diameter into which several million cubic feet of oil sand will fall and be heated to temperatures at which the oil may be recovered by conventional oil-field methods. Additional oil may be made recoverable by the shock energy from the explosion. Author's abstract condensed.

Oil and Gas Journal, 1960, Four-company team tackles Athabaska: Oil and Gas Jour., v. 58, no. 3, p. 44-45. 
Imperial Oil, Ltd., Cities Service Athabaska, Inc., Richfield Oil Corp., and Rayolite Oil Co. have joined in a major research project to tap the vast reserves locked in the Athabaska deposits. One new technique being tried uses a new German mining wheel, a mobile extraction unit, and a combination visbreaker and distillation plant. Six buckets attached to a huge wheel dig into the mining face and drop their load on a conveyor belt, which transfers the oil sand directly to an extraction unit. A 38-foot tail boom supports the conveyor belt that delivers sand to the mobile extractor. The self-propelled extractor moves with the mining equipment. First, it separates rocks and foreign matter from the oil sand. Next, a solvent diluent is added. Hot water is then added to precipitate the sand. The mixture of diluent, water, and bitumen is piped from the extraction unit to a separation plant, where the oil mixture is decanted and fed to the refinery. Author's text condensed.

Pasternack, D. S., 1963, Low-ash asphalt and coke from the Athabaska oilsands oil, in Athabaska oil sands: Research Council Alberta Inf. Ser. 45, p. 207-229.

Dehydrated Athabaska oil-sands oil, produced by either the hot-waterwashing process, the cold-water-washing process, or normal coking, yields coke which has too high an ash content to be of value for metallurgical purposes. Two simple methods are outlined to prevent excessive ash content in the coke; each represents a controlled partial deasphalting by means of partial thermal cracking of the oil. The first method consists of thermally cracking the oil and then filtrating the residue. The ash content of the coke produced from the filtrate depends upon the rate and extent of the thermal cracking, but it is generally less than 0.5 percent. In the second method, the residue (or the filtrate) from the thermal cracking is diluted with distillate and then either filtered or centrifuged to remove the insolubles. Prior removal of 40 percent by weight of distillate from the oil by slow thermal cracking yields an extract containing about 40 percent of the original asphaltenes and a coke with an ash content of about 0.07 percent. Author's abstract condensed.

Pasternack, D. S., and Clark, K. A., 1951, The components of the bitumen in Athabaska bituminous sand and their significance in the hot-waterseparation process: Research Council Alberta Rept. 58, 14 p.

During experimental work on the process of recovering bitumen from Athabaska bituminous sands, by washing them with hot water, irregularities occurred in the results which have to do with the mineral content and the yield of the recovered bitumen. Some bituminous sand beds at Bitumount evidently contain a bitumen whose components are in different proportion to each other than are the components of bitumen in other beds in the section. The fine clay in the bitumen appears to be closely associated with the asphaltenes. A method is proposed for avoiding the formation of troublesome emulsions when determining the proportion of saponifiable material in the bitumen. Differences in the relative viscosity of the bitumen would appear to be due primarily to variations in the relative proportions of the oily constituents. Authors' abstract condensed.

Pasternack, D. S., Hodgson, G. W., and Clark, K. A., 1951, Oil recovery from the Alberta oil sands by the hot-water-washing method: Athabaska Oil Sands Conf., Proc., Edmonton, Canada, p. 200-206. 
The hot-water-separation process as practiced by the Research Council of Alberta involves increasing the water content to about 12 percent by means of hot water and (or) steam while the oil sand is being heated to a temperature of about $176^{\circ} \mathrm{F}\left(80^{\circ} \mathrm{C}\right)$; during that time, a certain amount of mixing or kneading of the oil sand takes place. When the pulp reaches $176^{\circ} \mathrm{F}$, it is dropped into a turbulent stream of circulating plant water. The circulating plant water passing through the sand distributor transports the pulp into a comparatively large body of hot water (in the separation cell), the temperature of which is about $185^{\circ} \mathrm{F}\left(85^{\circ} \mathrm{C}\right)$. In the separation cell the oil floats as a froth and is skimmed off, and the bulk of the mineral matter sinks to the bottom and is removed and discarded. The plant water containing finely divided material in suspension is continuously withdrawn from this separation cell to a water settler. The purpose of the pulping operation is to rupture the oil film surrounding each sand grain. The washing operation disperses the pulp so that the oil flecks float in the form of froth and the sand grains sink. A turbulent flow of water in the sand distributor assists in dispersing the pulp. Authors' text condensed.

Peterson, W. S., and Gishler, P. E., 1951, The fluidized solids technique applied to Alberta oil-sands problem: Athabaska Oil Sands Conf., Proc., Edmonton, Canada, p. 207-236.

The direct distillation of oil from bituminous sand on a small pilot-plant scale is described in this report. Bench-scale tests demonstrated that when lumps of bituminous sand were dropped into a hot fluidized sand bed, the oil flashed off, and the lumps broke into individual grains of free-floating sand, each coated with a thin closely adhering film of coke. The heat requirements were high because of the high ratio of sand to oil. A net recovery of 80 percent was indicated. Temperature was found to be the only variable significantly affecting the yield or the properties of the oil. At the temperature used, considerable cracking takes place, resulting in a product with properties that differ markedly from those of the bitumen in the feed. A dry, fairly clean coker distillate can be produced simultaneously and continuously from the wet crude oil produced in the water-separation processes. Some initial work was done on catalytic cracking of wet crude. The pilot plant was not designed for this work, but the necessary modifications are planned. Authors' text condensed.

Plewes, A. C., 1951, Removal of sulfur from Alberta bitumen: Athabaska Oil Sands Conf., Proc., Edmonton, Canada, p. 306-329.

The recovery of hydrocarbon distillates from Athabaska crude oil is discussed, and the distillation of the crude in its unaltered state offers the only practical means of recovery. The presence of sulfur in the distillates makes the products less desirable. It has been found that the only known practical sulfur-removal procedure involves the hydrogenation of the coker distillate at low pressures. The treatment of coker distillate with bauxite offers no solution at present to the sulfur-removal problem, inasmuch as the bauxite is incapable of removing the sulfur-containing compounds in this boiling range from the distillate. The life of the bauxite catalyst is also reduced by the coke formation from olefinic compounds in the distillate. The use of furfural and some organic nitriles has been suggested for liquid-liquid extraction procedures. Distillation procedures involving the use of special solvents 
may be capable of withdrawing aromatic sulfur-containing compounds. Author's summary condensed.

Pow, J. R., Fairbanks, G. H., and Zamora, W. J., 1963, Descriptions and reserve estimates of the sands of Alberta, in Athabaska oil sands: Research Council Alberta Inf. Ser. 45, p. 1-15.

The oil-sands deposits are classified into three main groups, which are distinguished from each other by stratigraphic unit and by the area in which they occur. The Athabaska deposit occurs almost entirely within the Wabiskaw-McMurray unit, in northeastern Alberta; the Bluesky-Gething deposits are in the Bluesky and Gething Formations, in northwestern Alberta; and the Grand Rapids deposits occur in the Grand Rapids Formation, in north-central Alberta. Estimates of reserves in place, of recoverable reserves of raw oilsand oil, and of recoverable reserves of upgraded synthetic-crude oil are listed, respectively, as follows: Athabaska deposit: 626, 369, and 276 billion barrels. Bluesky-Gething deposits: 51, 28, and 21 billion barrels. Grand Rapids deposits: 33,18 , and 13 billion barrels. Authors' abstract condensed.

Research Council of Alberta, 1955, Hydrocarbon research: Research Council Alberta Rept. 73, 52 p. [p. 24].

The geology along the Firebag and Clearwater Rivers was surveyed in 1955 from the east boundary of Alberta to the Athabaska River. On both rivers, the eastern limit of the oil impregnation of the McMurray formation (Cretaceous) has been determined. Heavy oil was found in fractured Devonian limestones in T. 97, R. 7, west of the fourth meridian. Stratigraphically above the fractured Devonian, the McMurray formation is saturated with oil. Above the McMurray formation a black shale section was measured and the microfauna studied. Geologic sections on the upper Clearwater River and the High Hills River include an upper sand formation above the McMurray formation, separated from the McMurray formation by the Clearwater marine shale. Clay-mineral studies on the fine-grained part of the McMurray formation indicate that kaolinite-to-illite ratios support the contention that the McMurray is a continental deposit. Author's text condensed.

Round, G. F., 1960, The shear strength of McMurray oil sands: Canadian Mining and Metallurgy Bull., v. 53, p. 233-238.

Shear strength of this oil sand was measured in a controlled strain-type tester, modified so that the rate of deformation could be varied between 0.01725 and 0.1869 inches per minute. Effect of temperature was investigated by adapting the equipment to operate at both $71^{\circ} \mathrm{F}$ and $185^{\circ} \mathrm{F}$. It was concluded that oil content and temperature were significant variables for the degree of shear strength developed by the oil sand; increase in oil content and decrease in temperature each cause an increase in shear strength. The bulk-density range of 108.7-109.5 pounds per cubic foot gave angles of shearing resistance of $30^{\circ}-40^{\circ} \mathrm{F}$ and initial resistance values of $0.37-0.85$ pound per square inch. For the bulk-density range of 101-102 pounds per cubic foot, lower values of shear strength were obtained, indicating that compaction density was also of importance. Author's abstract condensed.

Russell, L. S., 1932, Mollusca from the McMurray formation of northern Alberta: Royal Soc. Canada Trans., ser. 3, v. 26, sec. 4, p. 37-44. 
Large quantities of the "tar sands" of the McMurray formation have been excavated in an effort to develop commercial methods for the extraction of the bitumen. This work has brought to light an important fossil fauna in the McMurray formation. The McMurray fauna is predominantly composed of nonmarine genera and is believed to be of fresh-water habitat. However, several forms present do suggest brackish water or possibly marine conditions. We must postulate, therefore, that the deposition of the McMurray formation took place near the sea level and shoreline. A lacustrine environment may be assumed for the Viviparidae, including the very abundant Lioplacodes bituminis, but their remains may have been transported and accumulated by stream action. The remaining species are all of possible fluviatile habitat. It is suggested, on the basis of the molluscan fauna, that the McMurray formation was developed under estuarine or near-estuarine conditions. Author's text condensed.

Schellhorn, H. W., 1963, Some aspects of high-capacity production with bucket-wheel excavators in open pits, in Athabaska oil sands: Research Council Alberta Inf. Ser. 45, p. 157-170.

This paper compares the anticipated conditions of mining in the Athabaska oil sands by means of bucket-wheel excavators with the known conditions encountered during many years of open-pit mining of brown coal in Germany with the same equipment. Excavators used in Germany are capable of producing 130,000 bank cubic yards per day of either overburden or brown coal. Surface mining of oil sand could be an excellent application of these wheels of large production capacity. The McMurray Formation is an oil-impregnated sandstone which will require high digging forces. These high digging forces must be applied at all points in the formation from top to bottom. In general, the McMurray Formation is 200 feet or less thick, and averages 150 feet. These dimensions are roughly similar to those in the coal fields where large bucket-wheel excavators are currently used. Author's text condensed.

Schrayer, G. J., Weismann, T. J., and Zarrella, W. M., 1960, Geochemical studies on the McMurray sand oil and selected Alberta Basin crude oils [abs.]: Geol. Soc. America Bull., v. 71, no. 12, pt. 2, p. 1968.

Chemical characterizations of the oils impregnating the McMurray sands from Bitumount to Grand Rapids and of selected Cretaceous and Devonian crude oils produced in the Alberta Basin have been determined. The ringanalysis data for the McMurray oil and for a Lower Cretaceous crude oil produced at Lloydminster gave similar results; parallel changes in the hydrocarbon structures with increasing molecular weight were also noted in these two oils. Mass spectrometric group analysis of the McMurray and Lloydminster pentane eluates showed the absence of free alkanes; about 40 percent of the hydrocarbon components were made up of noncondensed cycloalkanes, and another 40 percent of condensed cycloalkanes. Equivalent fractions of Devonian crude oils gave substantial differences in the ring analyses from those obtained in the Lower Cretaceous oils; the mass spectrometric results of the Devonian pentane fraction showed the presence of 28 percent free alkanes, 39 percent noncondensed cycloalkanes, and 21 percent condensed cycloalkanes. Authors' abstract condensed. 
Scott, Jean, Collins, G. A., and Hodgson, G. W., 1954, Trace metals in the McMurray oil sands and other Cretaceous reservoirs of Alberta: Canadian Mining and Metall. Bull., v. 47, no. 501, p. 36-42.

The occurrence of vanadium, nickel, and iron in the McMurray oil sand was investigated. The trace-metal content of samples obtained from widely separated points in the oil sand area was remarkably uniform. A typical oil-sand analysis is $360 \mathrm{ppm}$ (parts per million) $\mathrm{V}_{2} \mathrm{O}_{5}, 93 \mathrm{ppm} \mathrm{NiO}$, and $106 \mathrm{ppm}$ $\mathrm{Fe}_{2} \mathrm{O}_{3}$. A nearly constant proportion was found to exist for the vanadium and nickel oxides for the oil-sand oil and other Cretaceous oils. It is concluded that the oil-sand oil is not different in kind from other oils and that they may have a common origin. The authors believe that the presence of metalcontaining porphyrin compounds in the heavy black oils and the absence of similar compounds in the lighter oils indicate that the heavy oil should be regarded not as residue products from a common light-oil source, but as the precursors of lighter oils. Authors' abstract condensed.

Smoley, E. R., and Schutte, A. H., 1951, Continuous contact coking: Athabaska Oil Sands Conf., Proc., Edmonton, Canada, p. 251-256.

Coking has been used for converting heavy petroleum and asphalts to lighter distillates and coke. Along with the removal of the carbon, heavy minerals or metallic compounds are removed. In this process a continuous stream of coke particles circulates through the reactor vessel and the reheater. This circulation is obtained by means of mass-flow lift, which elevates the material as a dense-phase unagitated column. The lifting is powered by highpressure steam. At the oil-coke contacting zone, the lighter portions of the feed are vaporized, and the heavier unvaporized material is taken up as a liquid film on the coke particles. The wetted coke particles travel slowly down through the coking reactor as a compact bed and are allowed a residence time of approximately 30 minutes to complete the coking and drying reaction. At an intermediate point the product vapors are removed, and the coke descends to a stripping zone, where the final drying is obtained in an atmosphere of steam. The yields of hydrocarbon products are superior to those obtained by previous processes, and the coke product is yielded as a stream of dry highstrength pellets, free of fines. Authors' text condensed.

Spragins, F. K., 1967, Mining at Athabaska - A new approach to oil production: Jour. Petroleum Technology, v. 19, no. 10, p. 1337-1343.

This paper reports on two basically different mining approaches that could be used in a commercial tar-sands plant, and details both the economics and the equipment to be used. The overburden thickness determines how the bitumen might be recovered from the ore body. The Athabaska deposit is generally divided into two principal areas, one where the oil is recoverable by mining methods, and the other where oil is considered to be recoverable only by in-situ methods. Proved reserves of recoverable synthetic-crude oil in these two areas are estimated to be approximately 85 billion and 200 billion barrels, respectively. Early studies predicted that the mining ratio of overburden to saturated tar sand was about $0.5: 1$, whereas today it is estimated that the stripping ratio will be on the order of $2.5: 1$ and, under certain conditions, will approach 3.5:1. Recovery of synthetic crude oil from in-place bitumen is estimated at 70 volume percent for mined sand. By comparison the estimates of the recovery factor for the in-situ area is 40 volume percent. Author's text condensed. 
Sproule, J. C., 1938, Origin of McMurray oil sands, Alberta: Am. Assoc. Petroleum Geologists Bull., v. 22, no. 9, p. 1133-1152.

The writer believes that the in-situ theory, the Clearwater shale theory, the residual theory, and the lateral-migration theory are all possible explanations of the genesis of the McMurray bitumen, but they all, in some way, conflict with facts. However, the theory first proposed by Bell (1885), in which the petroleum entered the Cretaceous rocks from the underlying Devonian formations seems to be in close harmony with the evidence now available. It is suggested, further, that the petroleum entered the McMurray formation from the underlying Paleozoic at some point or points between the Athabaska and Peace Rivers, midway perhaps between McMurray and Fort Vermillion. During the Laramide revolution, crevices formed in the region's Paleozoic rocks, through which the petroleum invaded the McMurray formation and spread outward to the present boundaries of the impregnated body. Author's text condensed.

Sproule, J. C., 1951, The McMurray formation in its relation to oil occurrence: Athabaska Oil Sands Conf., Proc., Edmonton, Canada, p. 6-25.

The sediments making up the McMurray formation have been derived mainly from the lower Paleozoic Athabaska formation and adjoining parts of the Canadian Precambrian Shield. The oil in the McMurray formation was derived mainly from the upper part of the Devonian and, probably, also from Mississippian rocks. Undoubtedly, some of it is residual oil that was left behind during erosion of the Paleozoic surface, but most of it is probably due to oil seepages that have been active from the Early Cretaceous to the present, the principal migration having taken place during and immediately after the Laramide revolution. Author's text condensed.

Sproule, J. C., and Lloyd, G. V., 1963, A note on the comparison of McMurray and Melville Island oil sands, in Athabaska oil sands: Research Council Alberta Inf. Ser. 45, p. 27-29.

Oil-impregnated sands were discovered in the Canadian Arctic Archipelago near Marie Bay, Melville Island, in August 1962, by G. V. Lloyd of J. C. Sproule and Associates, Ltd. The areal extent of the oil sands is not known, but it seems certain that the oil impregnation in the Bjorne Formation of Triassic age is local and controlled by structure. This oil could probably be produced from wells if it occurs below the permafrost zone, which is 1,600 feet thick. Authors' abstract.

Stewart, G. A., 1963, Geological controls on the distribution of Athabaska oil-sands reserves, in Athabaska oil sands: Research Council Alberta Inf. Ser. 45 , p. 15-26.

The Athabaska oil sands within an area of 13,000 square miles in northern Alberta contain approximately 560 billion barrels of oil. Pre-Cretaceous topography developed on the eroded Devonian surface controls the distribution of the McMurray Formation and, in part, the oil it contains. Structures resulting from leaching of Elk Point evaporites, block faulting of Precambrian rocks, and several periods of subaerial erosion contributed to the development of the pre-Cretaceous landscape. Exploratory drilling has outlined the probable extent of the McMurray oil sands. Deposits of rich oil sand are concentrated in the basinal areas. Eighty percent of the oil reserves are found in 
only 40 percent of the total volume of McMurray sediments. Current knowledge of mining and processing Athabaska oil sand suggests that approximately 14 billion barrels of oil could be recovered by open-pit mining. Author's conclusions.

Vigrass, L. W., 1965, General geology of Lower Cretaceous heavy-oil accumulations in Western Canada: Jour. Canadian Petroleum Technology, v. 4, no. 4 , p. 168-176.

Lower Cretaceous sand reservoirs contain about 750 billion barrels of viscous heavy oil along a broad arcuate belt that extends from northwestern Alberta into west-central Saskatchewan. The heavy oil is pooled in the Mannville Group and, in a general sense, occurs in a marine-continental transition facies. The accumulation at Peace River is in a regional onlap feature. The accumulation in the Athabaska-Lloydminster region occurs across the crest and on the southwest flank of a regional anticlinal feature associated with the solution of salt from Middle Devonian beds. These features had formed by the end of Early Cretaceous time. Chemical and physical properties of oils from different accumulations show that they belong to a single oil system and suggest a common mode of origin. The Athabaska oil is young and immature and not evaporated, altered, or polymerized. The most tenable working hypothesis is that the hydrocarbons moved out of sediments in the deep basin in micellar solution in compaction waters. The hydrocarbons were deposited as heavy asphaltic oil where physical-chemical conditions were suitable. Early formed stratigraphic and structural "traps" served as loci of deposition for the heavy oil. Since deposition, and governed by buoyancy and capillarity, there has been some adjustment in position of the oil in the traps. Author's abstract.

Vigrass, L. W., 1968, Geology of Canadian heavy oil sands: Am. Assoc. Petroleum Geologists Bull., v. 52, no. 10, p. 1984-1999.

About 750 billion barrels of viscous heavy oil is in place in the Southern Interior Plains of Western Canada. Most of this oil occurs in sandstone beds of the Lower Cretaceous Mannville Group along a 600-mile belt that extends from Peace River, Alberta, through the "Athabaska tar sands" area, to Lloydminster, Saskatchewan. The Peace River deposit (50 billion barrels) is in a regional updip sandstone pinchout. The Athabaska-Lloydminster region (700 billion barrels) lies across the crest or on the southwest flank of a regional anticlinal feature associated with the solution of salt from Middle Devonian beds. The oils in Lower Cretaceous rocks belong to a single oil system, and all appear to be at or near the site at which a discrete oil phase was formed. The most acceptable hypothesis of origin is that hydrocarbons which moved out of the deep basin in micellar or colloidal solution in compaction waters were "precipitated" on anticlinal structures or in sandstone pinchouts, possibly as a result of a change in salinity of the formation waters. Author's abstract condensed.

Von Der Lin, Frances, 1961, Alberta reveals three new buried treasures: Oil and Gas Jour., v. 59, no. 31, p. 253.

In the course of drilling for oil and gas, three new oil-sand deposits similar to Athabaska were discovered. They are the Peace River, Hotchkiss East, and Red Earth Northeast deposits. Combined proved and possible reserves of the three have been conservatively estimated at more than 44 billion barrels of 
oil in place. The Peace River deposit is about 90 miles west of the Athabaska oil-soaked sand of the McMurray formation. The Peace River deposit is in the Gething (Lower Cretaceous) formation at a depth of about 2,000 feet; it correlates with the McMurray. Forty billion barrels of proved and possible reserves are estimated for the Peace River deposit. The Hotchkiss East deposit is about 50 miles west of Athabaska; it is also in the Gething, but is only 1,000 feet deep. Proved and possible reserves are believed to total about 3.3 billion barrels. The Red Earth Northeast deposit is the smallest of the three. Located near Peerless Lake, about 30 miles west of Athabaska, it has possible reserves of about 1 billion barrels. This oil accumulation occurs in the McMurray formation at a depth of 1,000 feet. Author's text condensed.

Ward, S. H., and Clark, K. A., 1950, Determination of the viscosities and specific gravities of the oils in samples of Athabaska bituminous sand: Research Council Alberta Rept. 57, 22 p.

A method was devised to extract oil from the bituminous sand in a standardized reproducible way and to correct the viscosity and specific-gravity measurements for any alterations that have occurred. The viscosity-temperature relationships for oils from bituminous sands from widely separated locations were determined. A relationship between the viscosity of a bituminous sand oil at $84.4^{\circ} \mathrm{F}$ and its specific gravity at $77^{\circ} \mathrm{F} / 77^{\circ} \mathrm{F}$ has been established. Results show that at $50^{\circ} \mathrm{F}$, which is about the temperature of bituminous sand at the quarry face, the viscosity of the oil in the southern part of the bituminous sand area in the neighborhood of McMurray is 100 times that of the oil in the northern part around Bitumount. The viscosity varies considerably from bed to bed throughout the 60-foot thickness of bituminous sand exposed at Bitumount. The specific gravities at $77^{\circ} \mathrm{F} / 77^{\circ} \mathrm{F}$ of bituminous sand oils examined vary between 1.002 and 1.027. Authors' abstract condensed.

Warren, T. E., 1951, Distribution of heat liberated from a well in bituminous sand: Athabaska Oil Sands Conf., Proc., Edmonton, Canada, p. 153-157.

This experiment is used to present quantitative data that can be used in assessing the feasibility of heating a bed of bituminous sand from a centrally located heat source. It is assumed that the initial temperature of the bituminous sand bed is $35^{\circ} \mathrm{F}$. If heat is supplied at the rate of $850 \mathrm{Btu}$ per linear foot of pipe per hour, the temperature at the pipe is calculated to rise to $720^{\circ} \mathrm{F}$ in 1 year. If the rate of heating is reduced to $670 \mathrm{Btu}$ per foot of pipe per hour, the temperature at the pipe reaches $720^{\circ} \mathrm{F}$ in 10 years. Author's text condensed.

Warren, T. E., Booth, F. L., Carson, R. E., and Bowles, K. W., 1951, Hydrosulphurization of coker distillate from Athabaska bitumen: Athabaska Oil Sands Conf., Proc., Edmonton, Canada, p. 289-305.

Five operating variables - temperature, pressure, liquid hourly space velocity, hydrogen feed rate, and sulfur content of feed - have been investigated. The temperature variable was found to exercise the greatest influence on the properties of the product. A small decrease in temperature below $420^{\circ} \mathrm{C}$ $\left(788^{\circ} \mathrm{F}\right)$ - while the other operating conditions, as stated above, remained constant - caused a large increase in the sulfur content of the product.

Webber, H. J., 1967, The oil sands of Alberta : Jour. Canadian Petroleum Technology, v. 6 , no. 4 , p. 146-149. 
In addition to the Athabaska deposit, another area in Alberta contains heavy-hydrocarbon deposits. This area, known as Cold Lake, is about 125 miles northeast of Edmonton. The properties of the heavy hydrocarbons there are transitional between bitumen of the oil sands to the north and the heavy crude oil of the Lloydminster area to the south. The Cold Lake oil sands occur within the Mannville Group of Early Cretaceous age. The quantity of bitumen in place in the evaluated area has been estimated at about 75 billion barrels, and, therefore, the area ranks as the third largest deposit in the world, behind the Atha. baska and Venezuela's Orinoco oil sands. Author's text condensed.

Williams, M. Y., 1949, Whence the oil of the Athabaska tar sands?: Royal Soc. Canada Trans., v. 43, ser. 3 , sec. 4 , p. 149-156.

Some time between the deposition of the McMurray sands and the Pleistocene, oil migrated into the sands and cemented them into their present condition. According to the monomolecular law, straight-parafine molecules have been converted into cyclic-hydrocarbon molecules, and lighter gaseous fractions have separated from the heavier fractions. In the presence of sulfur-bearing waters, asphalt has formed. Gases have been lost into the atmosphere by seepage. It seems clear that the clean fresh-water deltaic sands of the McMurray formation, with its tree trunks and land-plant fragments, were not the source of the bitumen. Present knowledge favors the theory that the oil in the bituminous sands of the Athabaska region originated in the underlying Middle Devonian limestones. Author's text condensed. 

